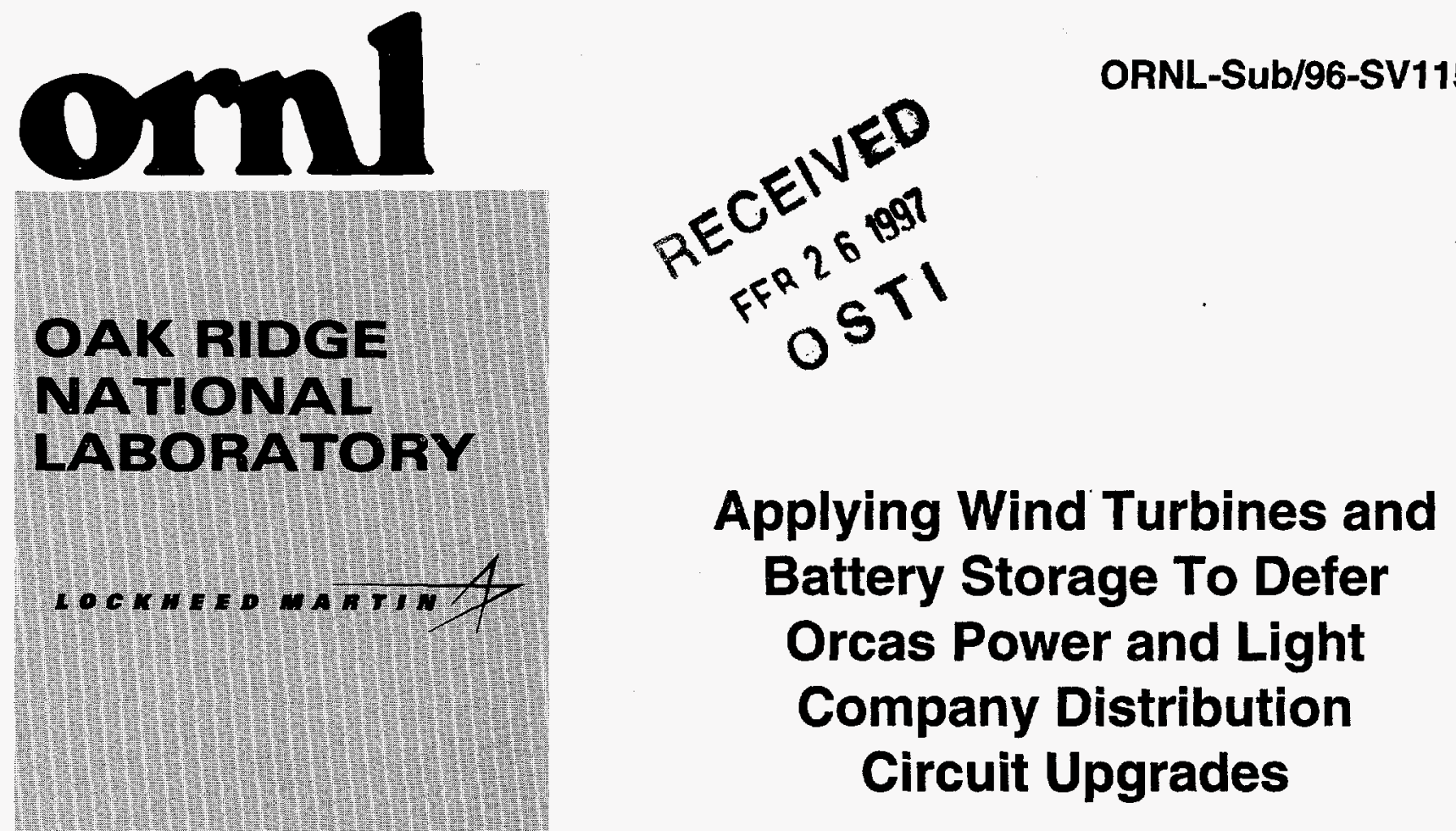

H. W. Zaininger

P. R. Barnes 
This report has been reproduced directly from the best available copy.

Avallable to DOE and DOE contractors from the Office of Scientific and Technical Information, P.O. Box 62, Oak Ridge, TN 37831; prices available from (423) 576-8401, FTS 626-8401.

Available to the public from the National Technical Information Service, U.S. Department of Commerce, 5285 Port Royal Rd., Springfield, VA 22161.

This report was prepared as an account of work sponsored by an agency of the United States Government. Neither the United States Government nor any agency thereof, nor any of their employees, makes any warranty, express or implied, or assumes any legal liability or responsibility for the accuracy, completeness, or usefulness of any information, apparatus, product, or process disclosed, or represents that its use would not infringe privately owned rights. Reference heriein to any specific commercial product, process, or service by trade name, trademark, manufacturer, or otherwise, does not necessarily constitute or imply its endorsement, recommendation, or favoring by the United States Government or any agency thereof. The views and opinions of authors expressed herein do not necessarily state or reflect those of the United States Government or any agency thereof. 


\section{DISCLAMIXx}

Portions of this docoment may be illegible in electronic image products. Images are produced from the best available origioal document. 


\title{
APPLYING WIND TURBINES AND BATTERY STORAGE TO DEFER ORCAS POWER \& LIGHT COMPANY DISTRIBUTION CIRCUIT UPGRADES
}

\author{
H. W. Zaininger \\ P.R. Barnes \\ March 1997 \\ Prepared by \\ Zaininger Engineering Company, Inc. \\ 1590 Oakland Road, Suite B211 \\ San Jose, CA 95131 \\ This work was partially co-sponsored by the \\ Utility Battery Storage Systems Program \\ Sandia National Laboratories \\ Albuquerque, New Mexico 87185 and Livermore, California 94550 \\ managed by \\ Lockheed Martin Research Corporation \\ for the \\ United States Department of Energy \\ under Contract DE-AC04-94AL85000 \\ and by the Power Systems Technology Program \\ Energy Division \\ Oak Ridge National Laboratory \\ Oak Ridge, Tennessee 37831 \\ under Subcontract 15X-SK724V \\ managed by \\ Lockheed Martin Research Corporation \\ for the \\ U.S. Department of Energy \\ under Contract DE-AC05-96OR22464
}




\section{CONTENTS}

LIST OF TABLES $\ldots \ldots \ldots \ldots \ldots \ldots \ldots \ldots \ldots \ldots \ldots \ldots \ldots \ldots \ldots \ldots \ldots \ldots \ldots \ldots \ldots$

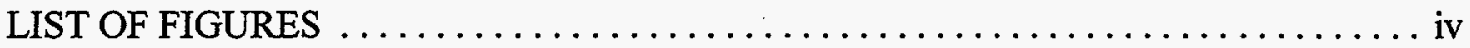

EXECUTTVE SUMMARY $\ldots \ldots \ldots \ldots \ldots \ldots \ldots \ldots \ldots \ldots \ldots \ldots \ldots \ldots \ldots \ldots \ldots \ldots$

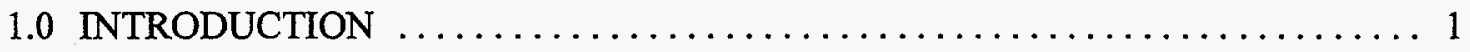

2.0 ORCAS POWER AND LIGHT COMPANY DISTRIBUTION PROJECT AND

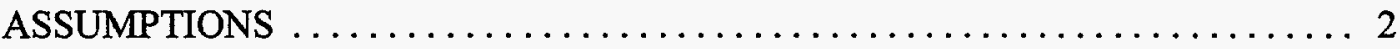

2.1 DISTRIBUTION CIRCUIT EXPANSION PROJECT $\ldots \ldots \ldots \ldots \ldots \ldots 2$

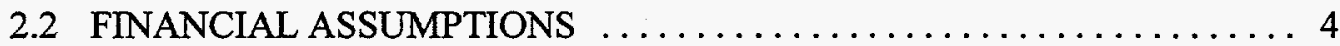

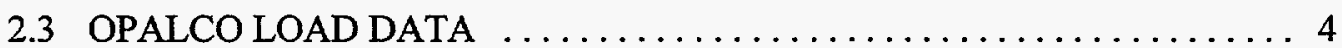

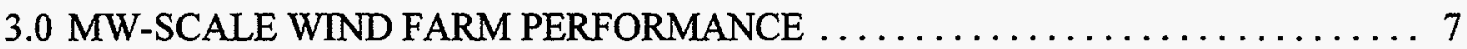

3.1 WIND FARM PERFORMANCE-MT. CONSTITUTION AT $163^{\prime} \ldots \ldots \ldots 7$

3.2 WIND FARM PERFORMANCE-MT. CONSTITUTION AT $120^{\prime} \ldots \ldots .8$

3.3 WIND FARM PERFORMANCE-OPALCO OFFICE AT 133' ... . . . . 13

3.4 WIND, TEMPERATURE AND PEAK LOAD CORRELATION $\ldots \ldots \ldots .17$

3.5 BATTERY STORAGE REQUIREMENTS $\ldots \ldots \ldots \ldots \ldots \ldots \ldots \ldots \ldots$

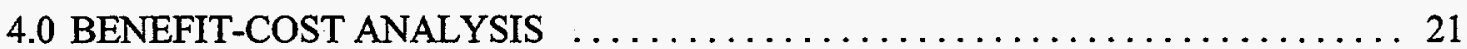

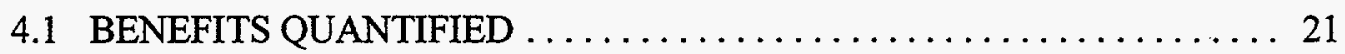

4.2 WIND TURBINE AND BATTERY STORAGE COSTS $\ldots \ldots \ldots \ldots \ldots 22$

4.3 ECONOMIC ASSESSMENT APPROACH $\ldots \ldots \ldots \ldots \ldots \ldots \ldots \ldots 22$

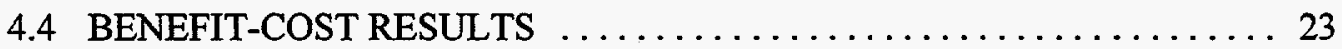

4.4.1 Wind Exceeds $26 \mathrm{mph}$ at Projected Extreme Annual Peak Loads . . . . 23

4.4.2 Measured $22 \mathrm{mph}$ Wind at Projected Extreme Annual Peak Loads . . . 25

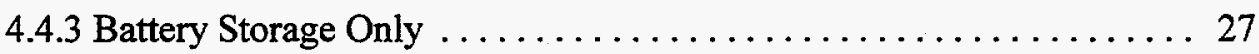

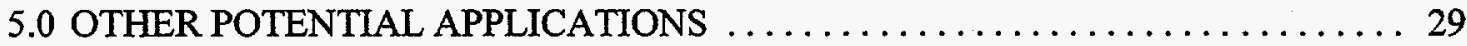

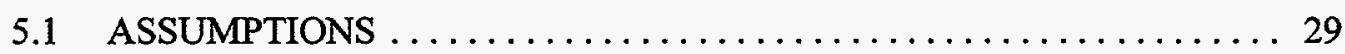

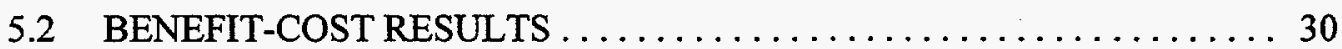

5.2.1 Wind Exceeds $26 \mathrm{mph}$ at Projected Extreme Annual Peak Loads . . . 30

5.2.2 Measured $22 \mathrm{mph}$ Wind at Projected Extreme Annual Peak Loads . . 31

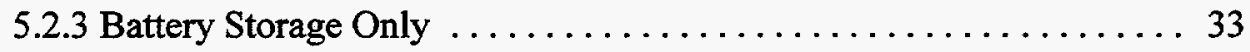

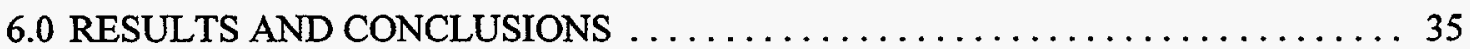

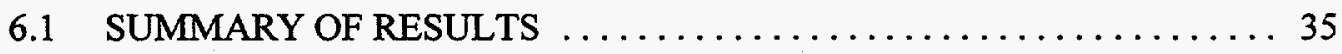

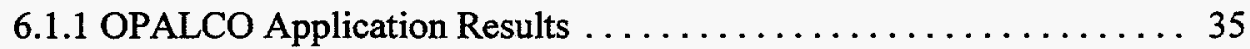

6.1.2 Extrapolation to Other Potential Applications . . . . . . . . . . . 36

6.2 CONCLUSIONS AND RECOMMENDATIONS $\ldots \ldots \ldots \ldots \ldots \ldots \ldots$

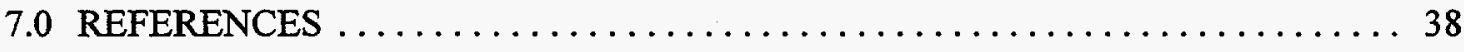


APPENDIX A HOURLY EASTSOUND LOADS FROM MARCH 1994

THROUGH FEBRUARY 1995

APPENDIX B HOURLY WIND AND MW-SCALE WIND PLANT PERFORMANCEMT. CONSTITUTION $163^{\prime} \ldots \ldots \ldots \ldots \ldots \ldots \ldots \ldots \ldots$ B-1

APPENDIX C HOURLY WIND AND MW-SCALE WIND PLANT PERFORMANCEMT. CONSTITUTION $120^{\prime} \ldots \ldots \ldots \ldots \ldots \ldots \ldots \ldots \ldots \ldots \ldots$ C- 1

APPENDIX D HOURLY WIND AND MW-SCALE WIND PLANT PERFORMANCE-

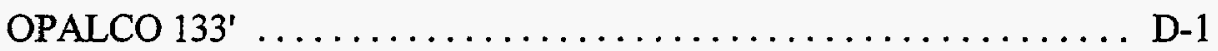

APPENDIX E HOURLY WIND AND TEMPERATURE DATA FOR 1994/1995 WINTER E-1 


\section{LIST OF TABLES}

Table 2.1. Projected extreme Eastsound winter peak load $\ldots \ldots \ldots \ldots \ldots \ldots \ldots \ldots$

Table 2.2. Schedule of Lopez-Eastsound 69-kV upgrade costs

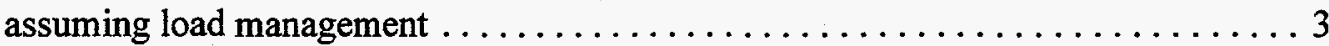

Table 2.3. Projected BPA power charges for $1996 \ldots \ldots \ldots \ldots \ldots \ldots \ldots \ldots \ldots \ldots \ldots$

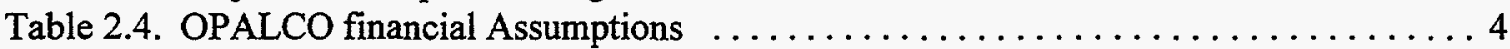

Table 3.1. MW-scale wind farm performance-Mt. Constitution at $163^{\prime} \ldots \ldots \ldots \ldots \ldots$

Table 3.2. MW-scale wind farm performance-Mt. Constitution at $120^{\prime} \ldots \ldots \ldots \ldots \ldots$

Table 3.3. MW-scale wind farm performance-OPALCO $133^{\prime} \ldots \ldots \ldots \ldots \ldots \ldots \ldots \ldots$

Table 4.1. Wind turbine and battery storage capital investments $\ldots \ldots \ldots \ldots \ldots \ldots \ldots 22$

Table 4.2. Benefit-cost results-install MW-scale wind farm in 2000 , wind speed at projected extreme annual peak exceeds $26 \mathrm{mph} \ldots \ldots \ldots \ldots \ldots \ldots \ldots \ldots \ldots$

Table 4.3. Table 4.3. Benefit-cost results-install $2-350 \mathrm{~kW}$ wind turbines in 2000 , wind speed at projected annual extreme peak exceeds $26 \mathrm{mph} \ldots \ldots \ldots \ldots 24$

Table 4.4. Benefit-cost results-install $1-350 \mathrm{~kW}$ wind turbine in 2000 , wind speed at projected annual extreme peak exceeds $26 \mathrm{mph} \ldots \ldots \ldots \ldots 24$

Table 4.5. Benefit-cost results-install MW-scale wind farm in 2000,

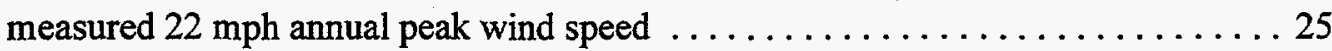

Table 4.6. Benefit-cost results-install MW-scale wind farm in 2000 and lease a $500-\mathrm{kW}$ battery storage plant in 2002 , measured

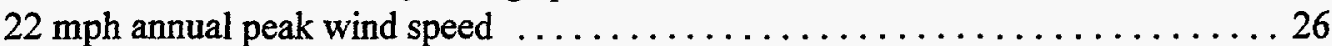

Table 4.7. Benefit-cost results-install MW-scale wind farm in 2000 and purchase a $500-\mathrm{kW}$ battery storage plant in 2002 , measured $22 \mathrm{mph}$ annual peak wind speed . . . . . . . . . . . . . . 27

Table 4.8. Benefit-cost results-lease a $500-\mathrm{kW}$ battery storage plant in 2000

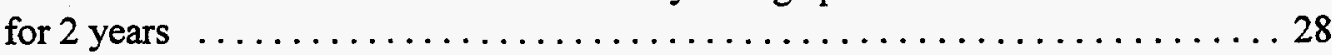

Table 4.9. Benefit-cost results-purchase a $500-\mathrm{kW}$ battery storage plant in $2000 \ldots \ldots 28$

Table 5.1. Assumed Demand and Energy Charges for $1998 \ldots \ldots \ldots \ldots \ldots \ldots \ldots . \ldots 29$

Table 5.2. Benefit-cost results-install a MW-scale wind farm in 2000 , wind speed at projected extreme annual peak exceeds $26 \mathrm{mph} \ldots \ldots \ldots \ldots \ldots 30$

Table 5.3. Benefit-cost results-install $2-350 \mathrm{~kW}$ wind turbines in 2000 , wind speed at projected annual extreme peak exceeds $26 \mathrm{mph} \ldots \ldots \ldots \ldots \ldots 31$

Table 5.4. Benefit-cost results-install $1-350 \mathrm{~kW}$ wind turbine in 2000 , wind speed at projected annual extreme peak exceeds $26 \mathrm{mph} \ldots \ldots \ldots \ldots$

Table 5.5. Benefit-cost results-install MW-scale wind farm in 2000, measured $22 \mathrm{mph}$ annual peak wind speed. . . . . . . . . . . . 32

Table 5.6. Benefit-cost results-install a MW-scale wind farm in 2000 and lease a $500-\mathrm{kW}$ battery storage plant in 2002 , measured $22 \mathrm{mph}$ annual peak wind speed . 33

Table 5.7. Benefit-cost results-install a MW-scale wind farm in 2000 and purchase a $500-\mathrm{kW}$ battery storage plant in 2002 , measured $22 \mathrm{mph}$ annual peak wind speed . 33

Table 5.8. Benefit-cost results-lease a $500-\mathrm{kW}$ battery storage plant in 2000 for 2 years .. 34 Table 5.9. Benefit-cost results-purchase a $500-\mathrm{kW}$ battery storage plant in $2000 \ldots \ldots . .34$ 


\section{LIST OF FIGURES}

Fig. 2.1. Monthly Eastsound peak day load shape - winter 1994-1995. . . . . . . . . 5 5

Fig. 2.2. Eastsound monthly peak loads-March 1994-February $1995 . \ldots \ldots \ldots \ldots \ldots \ldots$

Fig. 3.1. Per $\mathrm{kW}$ power curve for variable speed turbines. $\ldots \ldots \ldots \ldots \ldots \ldots \ldots$

Fig. 3.2. Average monthly wind speed on Mt. Constitution at 163'-

March 1994 through February 1995. . . . . . . . . . . . . . . . . . 10

Fig. 3.3. Impact on Eastsound load during annual peak day, February 13, 1995-

MW-scale wind farm located on Mt. Constitution at 163 . . . . . . . . . . 11

Fig. 3.4. Impact on Eastsound load during monthly peak day, January 2, 1995-

MW-scale wind farm located on Mt. Constitution at 163 '. . . . . . . . . . . . 11

Fig. 3.5. Average monthly wind speed on Mt. Constitution at $120^{\prime}-$

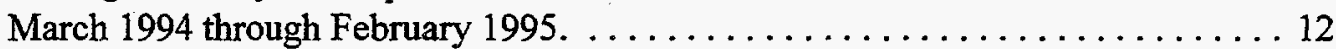

Fig. 3.6. Impact on Eastsound load during annual peak day, February 13, 1995-

MW-scale wind farm located on Mt. Constitution at $120^{\prime} . \ldots \ldots \ldots \ldots \ldots 12$

Fig. 3.7. Impact on Eastsound load during monthly peak day, January 2, 1995-

MW-scale wind farm located on Mt. Constitution at $120^{\prime} . \ldots \ldots \ldots \ldots \ldots$

Fig. 3.8. Average monthly wind speed near OPALCO at 133'-

March 1994 through February $1995 . \ldots \ldots \ldots \ldots \ldots \ldots \ldots \ldots \ldots \ldots . \ldots \ldots$

Fig. 3.9. Impact on Eastsound load during annual peak day, February 13, 1995-

MW-scale wind farm located near OPALCO at 133' ............... 15

Fig. 3.10. Impact on Eastsound load during the monthly peak day, January 2,1995-

MW-scale wind farm located near OPALCO at $1333^{\prime} \ldots \ldots \ldots \ldots \ldots \ldots$

Fig. 3.11. Expected monthly MW-scale wind farm energy production. . . . . . . . . 16

Fig. 3.12. Expected monthly peak load reduction from $M W$-scale wind farm. . . . . . 17

Fig. 3.13. Hourly wind and temperature on December 4, 1994. . . . . . . . . . . 18

Fig. 3.14. Hourly wind and temperature for February $13,1995 \ldots \ldots \ldots \ldots \ldots \ldots \ldots \ldots$

Fig. 3.15. Battery storage requirements to shave Eastsound

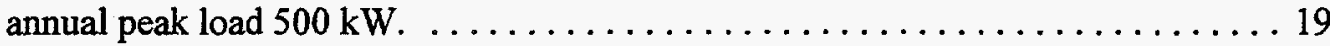

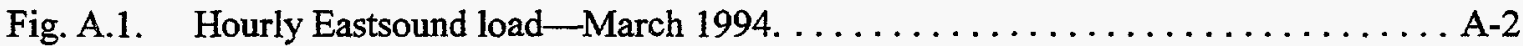

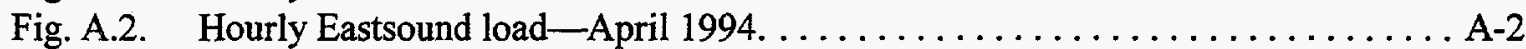

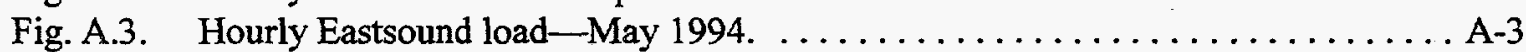

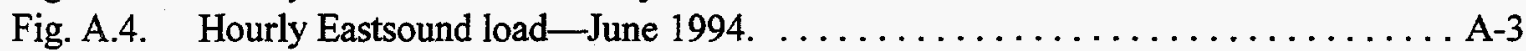

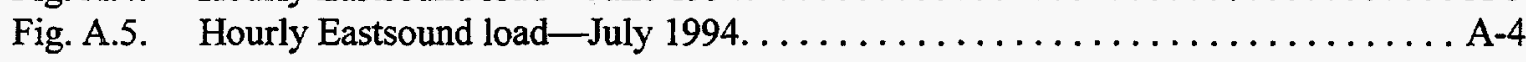

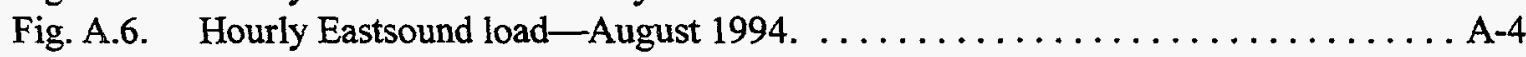

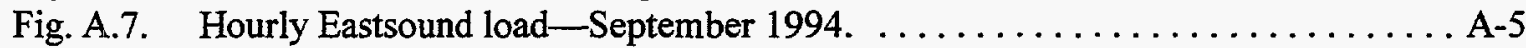

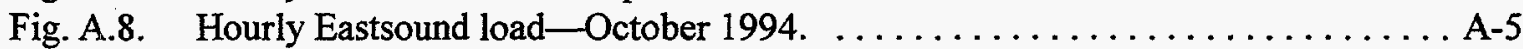

Fig. A.9. Hourly Eastsound load-November $1994 . \ldots \ldots \ldots \ldots \ldots \ldots \ldots \ldots \ldots \ldots$

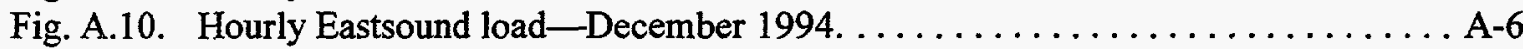

Fig. A.11. Hourly Eastsound load-January $1995 \ldots \ldots \ldots \ldots \ldots \ldots \ldots \ldots \ldots \ldots \ldots \ldots$

Fig. A.12. Hourly Eastsound load-February $1995 \ldots \ldots \ldots \ldots \ldots \ldots \ldots \ldots \ldots \ldots \ldots$

Fig. B.1. Hourly Mt. Constitution wind speed at 163'-March $1994 . \ldots . . . \ldots$. . . . B-2

Fig. B.2. Hourly Mt. Constitution wind speed at 163'-April 1994. . . . . . . . . . . . B-2

Fig. B.3. Hourly Mt. Constitution wind speed at $163^{\prime}$-May $1994 \ldots \ldots \ldots \ldots \ldots \ldots$. . . .

Fig. B.4. Hourly Mt. Constitution wind speed at 163'-June 1994. . . . . . . . . . . B-3

Fig. B.5. Hourly Mt. Constitution wind speed at 163 -July $1994 \ldots \ldots \ldots \ldots \ldots \ldots$. . . .

Fig. B.6. Hourly Mt. Constitution wind speed at 163 '-August $1994 \ldots \ldots \ldots \ldots$. . . . . B-4 
Fig. B.7. Hourly Mt. Constitution wind speed at 163'-September 1994. . . . . . . . . B-5

Fig. B.8. Hourly Mt. Constitution wind speed at 163'-October $1994 \ldots \ldots \ldots \ldots \ldots$. . . . B-5

Fig. B.9. Hourly Mt. Constitution wind speed at $163^{\prime}$-November $1994 \ldots \ldots \ldots \ldots \ldots$. . . . . 6

Fig. B.10. Hourly Mt. Constitution wind speed at 163'-December 1994 . . . . . . . . B-6

Fig. B.11. Hourly Mt. Constitution wind speed at 163 -January $1995 . \ldots \ldots \ldots \ldots \ldots$. . . .

Fig. B.12. Hourly Mt. Constitution wind speed at $163^{\prime}-$ February $1995 . \ldots \ldots \ldots \ldots$ B-7

Fig. B.13. Hourly MW-scale wind plant performance:

Mt. Constitution 163'-March 1994. . . . . . . . . . . . . . . . . . . . . . . . B-8

Fig. B.14. Hourly MW-scale wind plant performance:

Mt. Constitution 163-April 1994. . . . . . . . . . . . . . . . . . . . B-8

Fig. B.15. Hourly MW-scale wind plant performace:

Mt. Constitution 163'-May 1994. . . . . . . . . . . . . . . . . . B-9

Fig. B.16. Hourly MW-scale wind plant performance:

Mt. Constitution 163'-June 1994. . . . . . . . . . . . . . . . . . . B-9

Fig. B.17. Hourly MW-scale wind plant performance:

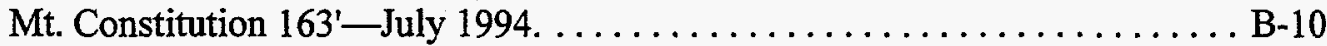

Fig. B.18. Hourly MW-scale wind plant performance:

Mt. Constitution 163'-August 1994. . . . . . . . . . . . . . . . . . . . . B-10

Fig. B.19. Hourly MW-scale wind plant performance:

Mt. Constitution 163'-September 1994. . . . . . . . . . . . . . . B-11

Fig. B.20. Hourly MW-scale wind plant performance:

Mt. Constitution 163'-October 1994..................... B-11

Fig. B.21. Hourly MW-scale wind plant performance:

Mt. Constitution 163'-November 1994 . . . . . . . . . . . . . . . . . . . B-12

Fig. B.22. Hourly MW-scale wind plant performance:

Mt. Constitution 163'-December 1994. . . . . . . . . . . . . . . . . . B-12

Fig. B.23. Hourly MW-scale wind plant performance:

Mt. Constitution 163'-January $1995 . \ldots \ldots \ldots \ldots \ldots \ldots \ldots$. . . . . . . . . . . . .

Fig. B.24. Hourly MW-scale wind plant performance:

Mt. Constitution 163'-February 1995. . . . . . . . . . . . . . B-13

Fig. B.25. Correlation between Eastsound load and MW-scale wind farm performance:

Mt. Constitution 163'-March 1994. ........................ . B-14

Fig. B.26. Correlation between Eastsound load and MW-scale wind farm performance:

Mt. Constitution 163'-April 1994. . . . . . . . . . . . . . . . . . . . . B-14

Fig. B.27. Correlation between Eastsound load and MW-scale wind farm performance:

Mt. Constitution 163'-May 1994. . . . . . . . . . . . . . . . . . . B-15

Fig. B.28. Correlation between Eastsound load and MW-scale wind farm performance:

Mt. Constitution 163'-June 1994. . . . . . . . . . . . . . . . . . . . . . . B-15

Fig. B.29. Correlation between Eastsound load and MW-scale wind farm performance:

Mt. Constitution 163'-July 1994. . . . . . . . . . . . . . . . . . . . . B-16

Fig. B.30. Correlation between Eastsound load and MW-scale wind farm performance:

Mt. Constitution 163'-August 1994. . . . . . . . . . . . . . . . B-16

Fig. B.31. Correlation between Eastsound load and MW-scale wind farm performance:

Mt. Constitution 163'-September 1994. . . . . . . . . . . . . . . . B-17

Fig. B.32. Correlation between Eastsound load and MW-scale wind farm performance:

Mt. Constitution 163'-October 1994. . . . . . . . . . . . . . . . . . . B-17 
Fig. B.33. Correlation between Eastsound load and MW-scale wind farm performance:

Mt. Constitution 163'-November 1994. . . . . . . . . . . . . . . . . B-18

Fig. B.34. Correlation Between Eastsound Load and MW-scale wind farm performance: Mt.

Constitution 163-December 1994. . . . . . . . . . . . . . . . . . . . . B-18

Fig. B.35. Correlation between Eastsound load and MW-scale wind farm performance:

Mt. Constitution 163-January 1995. ...................... B-19

Fig. B.36. Correlation between Eastsound load and MW-scale wind farm performance:

Mt. Constitution 163' -February 1995. ..................... B-19

Fig. C.1. Hourly Mt. Constitution wind speed at $120^{\prime}-$ March $1994 . \ldots \ldots \ldots \ldots \ldots$. .

Fig. C.2. Hourly Mt. Constitution wind speed at $120^{\prime}-$ April $1994 \ldots \ldots \ldots \ldots \ldots \ldots$ C-2

Fig. C.3. Hourly Mt. Constitution wind speed at $120^{\prime}-$ May $1994 \ldots \ldots \ldots \ldots \ldots \ldots$. . . . . . .

Fig. C.4. Hourly Mt. Constitution wind speed at $120^{\prime}$-June $1994 \ldots \ldots \ldots \ldots \ldots \ldots$. . . . . . .

Fig. C.5. Hourly Mt. Constitution wind speed at $120^{\prime}$-July $1994 \ldots \ldots \ldots \ldots \ldots \ldots$ C-4

Fig. C.6. Hourly Mt. Constitution wind speed at $120^{\prime}$-August $1994 \ldots \ldots \ldots \ldots$. . . . . . C-4

Fig. C.7. Hourly Mt. Constitution wind speed at 120'-September 1994 . . . . . . . . C-5

Fig. C.8. Hourly Mt. Constitution wind speed at $120^{\prime}-$ October $1994 \ldots \ldots \ldots \ldots$. . . . . C-5

Fig. C.9. Hourly Mt. Constitution wind speed at $120^{\prime}-$ November $1994 \ldots \ldots \ldots \ldots$. . . C-6

Fig. C.10. Hourly Mt. Constitution wind speed at 120'-December 1994 . . . . . . . . C-6

Fig. C.11. Hourly Mt. Constitution wind speed at $120^{\prime}$-January $1995 \ldots \ldots \ldots \ldots \ldots$ C-7

Fig. C.12. Hourly Mt. Constitution wind speed at $120^{\prime}-$ February $1995 . \ldots \ldots \ldots \ldots$ C-7

Fig. C.13. Hourly MW-scale wind plant performance:

Mt. Constitution 120 -March 1994. . . . . . . . . . . . . . . . . . C-8

Fig. C.14. Hourly MW-scale wind plant performance:

Mt. Constitution 120 -April 1994. . . . . . . . . . . . . . . . . . . C-8

Fig. C.15. Hourly MW-scale wind plant performance:

Mt. Constitution 120'-May 1994. ......................... C-9

Fig. C.16. Hourly MW-scale wind plant performance:

Mt. Constitution 120'-June 1994. . . . . . . . . . . . . . . . C-9

Fig. C.17. Hourly MW-scale wind plant performance:

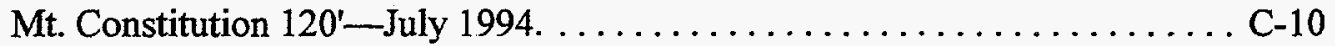

Fig. C.18. Hourly MW-scale wind plant performance

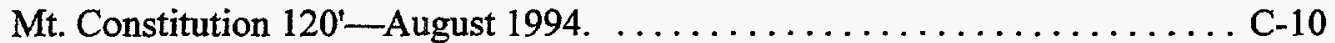

Fig. C.19. Hourly MW-scale wind plant performance:

Mt. Constitution 120'-September 1994. . . . . . . . . . . . . . . . . . . . C-11

Fig. C.20. Hourly MW-scale wind plant performance:

Mt. Constitution 120'-October 1994. . . . . . . . . . . . . . . . . C-11

Fig. C.21. Hourly MW-scale wind plant performance:

Mt. Constitution 120'-November 1994.................... C-12

Fig. C.22. Hourly MW-scale wind plant performance:

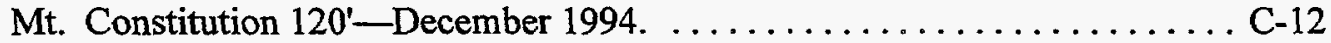

Fig. C.23. Hourly MW-scale wind plant performance:

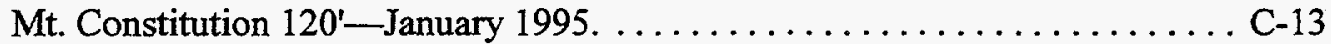

Fig. C.24. Hourly MW-scale wind plant performance:

Mt. Constitution $120^{\prime}$-February $1995 . \ldots \ldots \ldots \ldots \ldots \ldots \ldots \ldots \ldots$ C-13

Fig. C.25. Correlation between Eastsound load and MW-scale wind farm performance:

Mt. Constitution 120'-March 1994. . . . . . . . . . . . . . . . . . . C-14 
Fig. C.26. Correlation between Eastsound load and MW-scale wind farm performance:

Mt. Constitution 120'-April 1994. ..................... C-14

Fig. C.27. Correlation between Eastsound load and MW-scale wind farm performance:

Mt. Constitution 120'-May 1994. ........................ C-15

Fig. C.28. Correlation between Eastsound load and MW-scale wind farm performance:

Mt. Constitution 120'-June 1994. ....................... C-15

Fig. C.29. Correlation between Eastsound load and MW-scale wind farm performance:

Mt. Constitution $120^{\prime}$ - July 1994. . . . . . . . . . . . . . . . . . C-16

Fig. C.30. Correlation between Eastsound load and MW-scale wind farm performance:

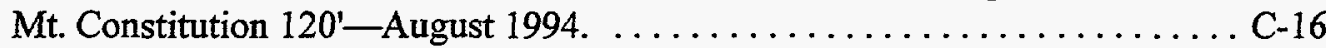

Fig. C.31. Correlation between Eastsound load and MW-scale wind farm performance:

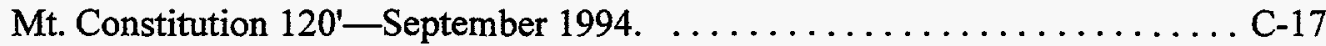

Fig. C.32. Correlation between Eastsound load and MW-scale wind farm performance:

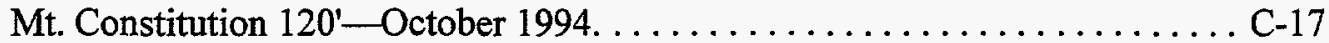

Fig. C.33. Correlation between Eastsound load and MW-scale wind farm performance:

Mt. Constitution $120^{\prime}-$ November 1994. . . . . . . . . . . . . . . . . . . . C-18

Fig. C.34. Correlation between Eastsound load and MW-scale wind farm performance:

Mt. Constitution 120-December 1994. . . . . . . . . . . . . . . . . . C-18

Fig. C.35. Correlation between Eastsound load and MW-scale wind farm performance:

Mt. Constitution $120^{\prime}$-January $1995 . \ldots \ldots \ldots \ldots \ldots \ldots \ldots \ldots \ldots$ C-19

Fig. C.36. Correlation between Eastsound load and MW-scale wind farm performance:

Mt. Constitution $120^{\prime}-$ February $1995 . \ldots \ldots \ldots \ldots \ldots \ldots \ldots \ldots \ldots \ldots \ldots \ldots \ldots$ C-19

Fig. D.1. Hourly OPALCO wind speed at $133^{\prime}-$ March $1994 . \ldots \ldots \ldots \ldots \ldots \ldots$ D-2

Fig. D.2. Hourly OPALCO wind speed at $133^{\prime}$-April $1994 . \ldots \ldots \ldots \ldots \ldots \ldots \ldots$ D-2

Fig. D.3. Hourly OPALCO wind speed at $133^{\prime}$-May $1994 \ldots \ldots \ldots \ldots \ldots \ldots \ldots \ldots$

Fig. D.4. Hourly OPALCO wind speed at $133^{\prime}$-June $1994 \ldots \ldots \ldots \ldots \ldots \ldots \ldots$. . . . . . . .

Fig. D.5. Hourly OPALCO wind speed at $133^{\prime}$-July $1994 . \ldots \ldots \ldots \ldots \ldots \ldots \ldots$. . . . . . . . .

Fig. D.6. Hourly OPALCO wind speed at $133^{\prime}$-August $1994 \ldots \ldots \ldots \ldots \ldots \ldots \ldots$. . . . . . . . .

Fig. D.7. Hourly OPALCO wind speed at 133 '-September $1994 \ldots \ldots \ldots \ldots \ldots \ldots$. . . $\ldots$

Fig. D.8. Hourly OPALCO wind speed at 133 -October $1994 \ldots \ldots \ldots \ldots \ldots \ldots \ldots$ D-5

Fig. D.9. Hourly OPALCO wind speed at 133 '-November $1994 . \ldots \ldots \ldots \ldots \ldots \ldots$. . 6

Fig. D.10. Hourly OPALCO wind speed at $133^{\prime}$-December $1994 . \ldots \ldots \ldots \ldots \ldots \ldots$ D-6

Fig. D.11. Hourly OPALCO wind speed at $133^{\prime}$-January $1995 . \ldots \ldots \ldots \ldots \ldots \ldots$. . . . . . .

Fig. D.12. Hourly OPALCO wind speed at $133^{\prime}-$ February $1995 . \ldots \ldots \ldots \ldots \ldots \ldots$ D-7

Fig. D.13. Hourly MW-scale wind plant performance:

OPALCO 133'-March 1994. ........................... D-8

Fig. D.14. Hourly MW-scale wind plant performance:

OPALCO 133'-April 1994. . . . . . . . . . . . . . . . . . . . D-8

Fig. D.15. Hourly MW-scale wind plant performance:

OPALCO 133 '-May 1994. . . . . . . . . . . . . . . . . . . . . . . D-9

Fig. D.16. Hourly MW-scale wind plant performance:

OPALCO 133 '-June 1994. . . . . . . . . . . . . . . . . . . . . . . D-9

Fig. D.17. Hourly MW-scale wind plant performance:

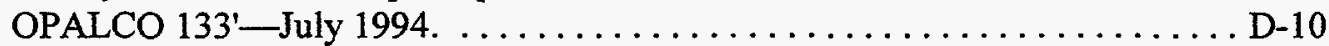

Fig. D.18. Hourly MW-scale wind plant performance:

OPALCO 133'-August 1994. . . . . . . . . . . . . . . . . . . . . D-10 
Fig. D.19. Hourly MW-scale wind plant performance:

OPALCO 133'-September 1994. ....................... D-11

Fig. D.20. Hourly MW-scale wind plant performance:

OPALCO 133'-October 1994. . . . . . . . . . . . . . . . . . . . . . . . D-11

Fig. D.21. Hourly MW-scale wind plant performance:

OPALCO 133'-November 1994.

Fig. D.22. Hourly MW-scale wind plant performance:

OPALCO 133'-December 1994.

Fig. D.23. Hourly MW-scale wind plant performance:

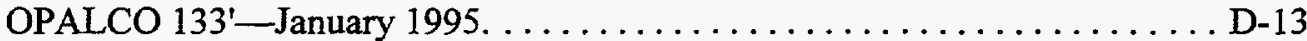

Fig. D.24. Hourly MW-scale wind plant performance:

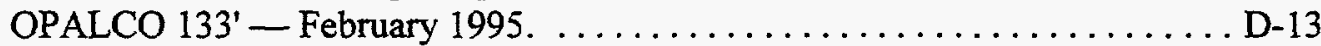

Fig. D.25. Correlation between Eastsound load and MW-scale wind farm performance:

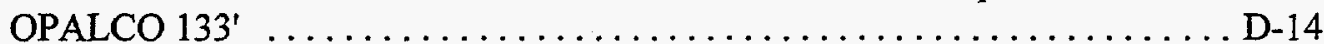

Fig. D.26. Correlation between Eastsound load and MW-scale wind farm performance: OPALCO 133'-April 1994. . . . . . . . . . . . . . . . . . . . . D-14

Fig. D.27. Correlation between Eastsound load and MW-scale wind farm performance: OPALCO 133 -May 1994.......................... D-15

Fig. D.28. Correlation between Eastsound load and MW-scale wind farm performance: OPALCO 133'-June 1994. . . . . . . . . . . . . . . . . . . . . . . . . . D-15

Fig. D.29. Correlation between Eastsound load and MW-scale wind farm performance:

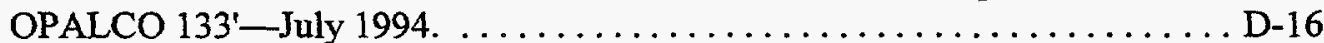

Fig. D.30. Correlation between Eastsound load and MW-scale wind farm performance: OPALCO 133'-August 1994. . . . . . . . . . . . . . . . . . . . . . . . . D-16

Fig. D.31. Correlation between Eastsound load and MW-scale wind farm performance: OPALCO 133'-September 1994. . . . . . . . . . . . . . . . . . . D-17

Fig. D.32. Correlation between Eastsound load and MW-scale wind farm performance: OPALCO 133'-October 1994. ........................ D-17

Fig. D.33. Correlation between Eastsound load and MW-scale wind farm performance: OPALCO $133^{\prime}$-November 1994. . . . . . . . . . . . . . . . . . . . . D D-18

Fig. D.34. Correlation between Eastsound load and MW-scale wind farm performance: OPALCO 133'-December 1994. ........................ D-18

Fig. D.35. Correlation between Eastsound load and MW-scale wind farm performance: OPALCO 133'-January $1995 . \ldots \ldots \ldots \ldots \ldots \ldots \ldots \ldots \ldots$. . . . . . . . . . . . . . . . . .

Fig. D.36. Correlation between Eastsound load and MW-scale wind farm performance: OPALCO 133'-February 1995. . . . . . . . . . . . . . . . . D 19

Fig. E.1. Hourly wind and temperature-December $1994 \ldots \ldots \ldots \ldots \ldots \ldots \ldots \ldots$ E-2

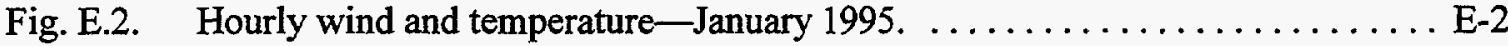

Fig. E.3. Hourly wind and temperature-February $1995 . \ldots \ldots \ldots \ldots \ldots \ldots \ldots \ldots$ 


\section{EXECUTIVE SUMMARY}

\section{INTRODUCTION}

Renewable energy technologies, such as solar and wind power are environmentally beneficial sources of electric power generation. A recent Oak Ridge National Laboratory study (ORNL) report, entitled The Integration of Renewable Energy Sources into Electric Power Distribution Systems, ORNL-6,775/V1 and V2, showed that integrating these beneficial solar and wind energy sources into electric power distribution systems can provide significant, sitespecific transmission and distribution system benefits, commonly referred to as "distributed utility benefits", in addition to nonsite-specific generation system benefits. ${ }^{1-2}$ The results of this study indicated that MW-scale wind farms integrated into utility distribution systems can be an economic alternative in locations where there is a good wind resource, and appropriate sitespecific distributed utility benefits apply.

One of the seven utility case studies in the previous ORNL study consisted of a preliminary benefit-cost assessment of potential MW-scale renewable energy sources and battery storage applications on an Orcas Power and Light Company (OPALCO) $25-\mathrm{kV}$ distribution circuit. The results from this preliminary benefit-cost assessment indicated that if there was a good wind site on Orcas Island near Eastsound, a MW-scale wind farm may be a cost-effective resource for OPALCO. If there is good correlation between high winds and the Eastsound annual peak loads, a MW-scale wind farm can defer the planned upgrade of the 25-kV Lopez-Eastsound circuit to $69 \mathrm{kV}$. If there is not perfect correlation between high winds and Eastsound peak loads, transportable battery storage may be used to enhance the wind farm performance during the distribution circuit upgrade deferral period by backing up the wind farm during any low wind periods.

The purpose of this study is to conduct a detailed assessment of the OPALCO system to determine the potential for deferring the costly upgrade of the $25-\mathrm{kV}$ Lopez-Eastsound circuit, by the application of a MW-scale wind farm and battery storage facilities as appropriate. Local wind resource data has been collected over the past year and used to determine MW-scale wind farm performance. This hourly wind farm performance data is used with measured hourly Eastsound load data, and recent OPALCO distribution system expansion plans and cost projections in performing this detailed benefit-cost assessment.

\section{OPALCO Application Results}

Expected benefits to OPALCO associated with adding a MW-scale wind farm and battery storage are:

- defer planned Lopez-Eastsound circuit upgrade to $69 \mathrm{kV}$,

- energy charge reduction,

- monthly demand charge reduction,

- $\quad$ reduction in distribution losses; and

- $\quad$ Energy Policy Act (EPACT) production incentive.

Deferral of the Lopez-Eastsound distribution circuit upgrades, energy displacement, and monthly demand charge reduction are the most important benefits. Potential reduction in distribution losses are small because upgrading to $69 \mathrm{kV}$ also reduces losses. The EPACT 
production incentive benefit is law, and hopefully will be funded by the year 2000 . However, there is currently no mechanism for the Federal government to fund this incentive for publicly owned utilities.

Wind data collection results indicate that Mt. Constitution is a good wind site. Assuming the measured winds at the instrument height of $163^{\prime}$, the resulting annual capacity factor for a wind farm installed at this location is $21.2 \%$. Measured wind data indicated good correlation between high winds and projected annual Eastsound peak load. A wind speed of approximately $22 \mathrm{mph}$ was measured during the actual annual 1994-1995 winter Eastsound peak load during this mild winter. It is very likely that winds of at least $22 \mathrm{mph}$ will be experienced during projected extreme winter peak load conditions.

If the wind can be counted on to exceed $26 \mathrm{mph}$ during projected extreme annual Eastsound peak loads, distribution facility deferral benefits totaling full nameplate $\mathrm{kW}$ capacity will accrue to a MW-scale wind farm consisting of up to $3-350 \mathrm{~kW}$ variable speed wind turbines installed on Mt. Constitution in 2000 . Adding $1-350 \mathrm{~kW}$ wind turbine defers the planned Lopez-Eastsound circuit upgrade to $69 \mathrm{kV}$ for 2 years resulting in total economic benefits of $\$ 1,928 / \mathrm{kW}$ and a benefit-to-cost ratio of 1.96 . Adding $2-350 \mathrm{~kW}$ wind turbines defers the planned circuit upgrade for 3 years resulting in total economic benefits of $\$ 1,570 / \mathrm{kW}$ and a benefit-to-cost ratio of 1.60 . Adding three $3-350 \mathrm{~kW}$ wind turbines defers the planned upgrade for 4 years resulting in total benefits of $\$ 1,443 / \mathrm{kW}$ and a benefit-to-cost ratio of 1.47 .

If the wind can be counted on to equal or exceed the measured $22 \mathrm{mph}$ during projected extreme annual Eastsound peak loads, distribution deferral benefits of approximately half the nameplate $\mathrm{kW}$ capacity will accrue to a MW-scale wind farm installed on Mt. Constitution in 2000 . In this case, adding $3-350 \mathrm{~kW}$ wind turbines defers the planned circuit upgrade to $69 \mathrm{kV}$ for 2 years, resulting in total economic benefits of $\$ 1,129 / \mathrm{kW}$ and a benefit-to-cost ratio of 1.15 .

Assuming the above $22 \mathrm{mph}$ wind case, adding a 500-kW, 2-hour battery storage plant near Eastsound will enhance the MW-scale wind farm performance, and increase benefits to OPALCO. Adding the battery storage plant will provide full 1,050-kW Eastsound peak load reduction capability. OPALCO can also operate the battery to reduce monthly demand charges throughout the year. In addition the battery storage can back up the wind farm during unexpected low wind conditions. Leasing the battery storage plant for 2 years increases the MW-scale wind farm benefits to $\$ 1,330 / \mathrm{kW}$ and the benefit-to-cost ratio to 1.24 .

If potential EPACT benefits are not included, the above total benefits associated with adding a wind farm will be reduced about $\$ 150 / \mathrm{kW}$.

\section{Extrapolation to Other Potential Applications}

It is expected that the similar benefits from adding a MW-scale wind farm and battery storage in this study will also apply to many other winter peaking utilities throughout the northern United States. Distribution circuit upgrades are based on extreme annual winter peak design loads which occur during coincident low temperature and high wind ambient conditions for many other winter peaking utilities. For many of these utilities in different regions of the United States, demand and energy charges are expected to be significantly higher than OPALCO's costs, as shown in the previous study.$^{1-2}$ Assuming these representative higher demand and energy charges, significantly larger benefits are expected to accrue to $\mathrm{MW}$-scale wind farms and battery storage.

If the wind can be counted on to exceed $26 \mathrm{mph}$ during extreme annual peak loads, the following increased benefits are likely in other potential applications. Adding 1-350 kW wind 
turbine results in total economic benefits of $\$ 2,416 / \mathrm{kW}$ vs $\$ 1,928 / \mathrm{kW}$ and a benefit-to-cost ratio of 2.46 vs 1.96 . Adding $2-350 \mathrm{~kW}$ wind turbines results in total economic benefits of $\$ 2,058 / \mathrm{kW}$ vs $\$ 1,570 / \mathrm{kW}$ and a benefit-to-cost ratio of 2.09 vs 1.60 . Adding $3-350 \mathrm{~kW}$ wind turbines results in total economic benefits of $\$ 1,929 / \mathrm{kW}$ vs $\$ 1,443 / \mathrm{kW}$ and a benefit-to-cost ratio of $1.96 \mathrm{vs}$ 1.47 .

If the wind can be counted on to exceed $22 \mathrm{mph}$ during projected extreme annual peak loads, adding 3-350 kW wind turbines results in total economic benefits of $\$ 1,603 / \mathrm{kW}$ vs $\$ 1,129 / \mathrm{kW}$ and a benefit-to-cost ratio of 1.63 vs 1.15 . Again, leasing a $500-\mathrm{kW}, 2$-hour battery storage plant significantly enhances the wind farm benefits. In this case, leasing the battery plant increases the wind farm benefits to $\$ 1,830 / \mathrm{kW}$ and the benefit-to-cost ratio to 1.71 .

Again, if potential EPACT benefits are not included, the above total benefits associated with adding a wind farm will be reduced about $\$ 150 / \mathrm{kW}$, as this is independent of demand and energy costs.

If a transportable $500-\mathrm{kW}, 2$-hour battery storage plant is leased in 2000 for 2 years, the resulting total benefits are $\$ 795 / \mathrm{kW}$ vs $\$ 727 / \mathrm{kW}$ and the benefit-to-cost ratio is 4.02 vs 3.68 . If the battery plant is purchased in 2000 , total benefits are $\$ 1,972 / \mathrm{kW}$ vs $\$ 1,418 / \mathrm{kW}$ and the benefit-to-cost ratio is 2.11 vs 1.52 .

\section{CONCLUSIONS AND RECOMMENDATIONS}

The following conclusions and recommendations apply to the application of wind farms and battery storage near Eastsound:

- The measured wind data in this project indicate that Mt. Constitution is a good wind site, and that the OPALCO office site is a poor wind site.

- Adding a MW-scale wind farm at Mt. Constitution is an economic alternative to upgrading the Lopez-Eastsound circuit to $69 \mathrm{kV}$ in 2000 .

- Adding a battery storage plant in conjunction with the wind farm will enhance wind farm performance and increase the economic viability of the wind farm.

- Leasing a $500-\mathrm{kW}, 2$-hour battery storage plant in 2000 for 2 years without the wind farm is also an economic alternative to upgrading the Lopez-Eastsound circuit to $69 \mathrm{kV}$ in 2000 .

- It is recommended that detailed wind measurements over the 1995-1996 winter be continued at the Mt. Constitution site to establish wind speeds during projected extreme peak load conditions.

- It is recommended that OPALCO develop functional specifications and obtain detailed cost estimates for wind turbines, and expected lease costs for transportable battery storage from potential vendors.

The following general conclusions and recommendations apply to potential applications of wind farms and battery storage to other winter peaking utility systems: 
- Adding a MW-scale wind farm is expected to be an economic alternative to upgrading distribution facilities at many winter peaking utilities throughout the northern United States.

- Strategically adding battery storage in conjunction with a wind farm will significantly enhance wind farm benefits at locations where full wind farm MW capacity can not be counted on during extreme winter peak design loading conditions.

- The magnitude of wind farm and battery storage economic benefits is expected to vary significantly on both a site-specific and utility-specific basis, based on wind characteristics, utility distribution design characteristics, and cost variations.

- Extremely high winds and extremely high utility costs appear unnecessary to economically justify the addition of MW-scale wind farms and battery storage on many winter peaking utility systems in the northern United States. Instead, good wind sites coupled with normal utility costs are expected to result in numerous cases of economic viability.

- It is recommended that other potential applications of MW-scale wind farms and battery storage for other winter peaking utility systems in the northern United States be identified, and the economic viability investigated on a site-specific basis similar to this study. 


\section{INTRODUCTION}

Renewable energy technologies, such as solar and wind power are environmentally beneficial sources of electric power generation. A recent Oak Ridge National Laboratory study (ORNL) report, entitled The Integration of Renewable Energy Sources into Electric Power Distribution Systems, ORNL-6,775/V1 and V2, showed that integrating these beneficial solar and wind energy sources into electric power distribution systems can provide significant, sitespecific transmission and distribution system benefits, commonly referred to as "distributed utility benefits", in addition to nonsite-specific generation system benefits. ${ }^{1-2}$ The results of this study indicated that $\mathrm{MW}$-scale wind farms integrated into utility distribution systems can be an economic alternative in locations where there is a good wind resource, and appropriate sitespecific distributed utility benefits apply.

One of the seven utility case studies in the previous ORNL study consisted of a preliminary benefit-cost assessment of potential MW-scale renewable energy sources and battery storage applications on an Orcas Power and Light Company (OPALCO) $25-\mathrm{kV}$ distribution circuit. The results from this preliminary benefit-cost assessment indicated that if there was a good wind site on Orcas Island near Eastsound, a MW-scale wind farm may be a cost-effective resource for OPALCO. If there is good correlation between high winds and the Eastsound annual peak loads, a MW-scale wind farm can defer the planned upgrade of the 25-kV Lopez-Eastsound circuit to $69 \mathrm{kV}$. If there is not perfect correlation between high winds and Eastsound peak loads, transportable battery storage may be used to enhance the wind farm performance during the distribution circuit upgrade deferral period by backing up the wind farm during any low wind periods.

The purpose of this study is to conduct a detailed assessment of the OPALCO system to determine the potential for deferring the costly upgrade of the 25-kV Lopez-Eastsound circuit, by the application of a MW-scale wind farm and battery storage facilities as appropriate. Local wind resource data has been collected over the past year and used to determine MW-scale wind farm performance. This hourly wind farm performance data is used with measured hourly Eastsound load data, and recent OPALCO distribution system expansion plans and cost projections in performing this detailed benefit-cost assessment.

Section 2 describes the OPALCO distribution circuit expansion project and assumptions. Section 3 describes MW-scale wind farm performance results. Section 4 contains the economic benefit-cost results for the wind farm and battery storage applications on the OPALCO system using OPALCO system design criteria and cost assumptions. Section 5 presents a recalculation of the benefit-cost results for similar potential wind farm and battery storage applications on other utility systems with higher marginal energy and demand costs. And Section 6 presents conclusions and recommendations. 


\subsection{ORCAS POWER AND LIGHT COMPANY DISTRIBUTION PROJECT AND ASSUMPTIONS}

\subsection{DISTRIBUTION CIRCUTT EXPANSION PROJECT}

OPALCO serves the San Juan Islands in Puget Sound, north of Seattle, Washington. OPALCO power is supplied by Bonneville Power Administration (BPA). The BPA interconnection point is on Lopez Island.

The distribution circuit in question consists of a $25-\mathrm{kV}$ circuit which extends from the BPA interconnection point on Lopez Island to Shaw Island, and then on to Orcas Island, using both overhead and under water construction. The far end of the line is located at Eastsound, where OPALCO has a $1 \mathrm{MW}$ diesel plant.

OPALCO is currently experiencing serious voltage problems on this $25-\mathrm{kV}$ circuit. For example, during 1992/93 winter peak season when the Eastsound load was $6,336 \mathrm{~kW}$, the resulting voltage drop was $8 \%$. OPALCO has performed a load flow study which shows that if the Eastsound substation load at the end of the line exceeds approximately $7,600 \mathrm{~kW}$, excessive voltage drop occurs, requiring the circuit to be upgraded to $69 \mathrm{kV}$. During this OPALCO load flow study, the other substation loads at Shaw and Orcas were set to zero and there was minimal impact on the resulting circuit voltage drop. Thus, this $25-\mathrm{kV}$ circuit is currently voltage-limited and this voltage limit is determined by the magnitude of the annual peak load at the Eastsound substation.

As discussed with OPALCO personnel and described previously, this voltage-limited $25-\mathrm{kV}$ Lopez to Eastsound distribution circuit is currently planned to be upgraded to $69 \mathrm{kV}$ because of the projected peak load growth at Eastsound, which causes the voltage problems. During the preliminary study performed during 1993, this circuit was originally scheduled to be uprated to $69 \mathrm{kV}$ in 1995 to plan for potential extreme Eastsound peak loads in the 1995-1996 winter. ${ }^{2}$

OPALCO is currently implementing a load management plan to reduce Eastsound peak loads. Table 2.1 presents the currently projected extreme Eastsound winter peak loads through 2014, projected load management peak load reductions, and the resulting net extreme Eastsound winter peak load. Implementation of this load management plan will reduce projected Eastsound peak loads up to $1,500 \mathrm{~kW}$ and will defer the previously planned circuit upgrade to $69 \mathrm{kV}$ from 1995 to 2000, when the projected net extreme peak Eastsound load during the 2000-2001 winter season will be 7,675 kW. After the 2000-2001 winter season the projected net Eastsound annual winter peak grows at over $300 \mathrm{~kW}$ per year. This will be the base case circuit load projection assumption for this study.

Table 2.2 presents a schedule of Lopez-Eastsound circuit and substation upgrade cost projections from OPALCO's 1995 long range plan, assuming the extreme Eastsound peak load projections and the load management plan presented in Table 2.1. By 1998, circuit upgrade capital investments total $\$ 1,160,000$ in $1995 \$$. By 2000 , an additional capital investment of $\$ 830,000$ is required to complete the $69-\mathrm{kV}$ circuit upgrade. Additional circuit capital investments of $\$ 1,500,000$ and $\$ 1,200,000$ are planned for 2006 and 2008 respectively. 
Table 2.1. Projected extreme Eastsound winter peak load

\begin{tabular}{cccc}
\hline Year & $\begin{array}{c}\text { Extreme } \\
\text { Peak Load } \\
(\mathbf{k W})\end{array}$ & $\begin{array}{c}\text { Load } \\
\text { Management } \\
\text { Reduction } \\
\text { (kW) }\end{array}$ & $\begin{array}{c}\text { Net } \\
\text { Extreme } \\
\text { Peak Load } \\
\text { (kW) }\end{array}$ \\
\hline 1994 & 7,551 & & 7,551 \\
1995 & 7,800 & 375 & 7,425 \\
1996 & 8,057 & 600 & 7,457 \\
1997 & 8,323 & 825 & 7,498 \\
1998 & 8,598 & 1,050 & 7,548 \\
1999 & 8,882 & 1,275 & 7,607 \\
2000 & 9,175 & 1,500 & 7,675 \\
2001 & 9,478 & 1,500 & 7,978 \\
2002 & 9,790 & 1,500 & 8,290 \\
2003 & 10,113 & 1,500 & 8,613 \\
2004 & 10,447 & 1,500 & 8,947 \\
2005 & 10,792 & 1,500 & 9,292 \\
2006 & 11,148 & 1,500 & 9,648 \\
2007 & 11,516 & 1,500 & 10,016 \\
2008 & 11,896 & 1,500 & 10,396 \\
2009 & 12,289 & 1,500 & 10,789 \\
2010 & 12,694 & 1,500 & 11,194 \\
2011 & 13,113 & 1,500 & 11,613 \\
2012 & 13,546 & 1,500 & 12,046 \\
2013 & 13,993 & 1,500 & 12,493 \\
2014 & 14,454 & 1,500 & 12,954 \\
\hline & & & \\
\hline
\end{tabular}

Table 2.2. Schedule of Lopez-Eastsound 69-kV upgrade costs assuming load management

\begin{tabular}{|c|c|c|}
\hline Year & Project & Projected Cost (1995\$) \\
\hline \multirow[t]{5}{*}{1998} & New substation on Orcas & 730,000 \\
\hline & Construct cable terminal on Shaw & 140,000 \\
\hline & Construct cable terminal on Orcas & 140,000 \\
\hline & Install 69-kV switch on Orcas & 150,000 \\
\hline & 1998 Subtotal & $1,160,000$ \\
\hline \multirow[t]{3}{*}{2000} & Terminate existing Shaw_-Orcas cable & 330,000 \\
\hline & New substation on Shaw & 500,000 \\
\hline & 2000 Subtotal & 830,000 \\
\hline 2006 & Second Lopez to Shaw cable & $1,500,000$ \\
\hline 2008 & Second Shaw to Orcas cable & $1,200,000$ \\
\hline
\end{tabular}




\subsection{FINANCIAL ASSUMPTIONS}

OPALCO supplied recent projected BPA demand and energy charge rates for 1996, as shown in Table 2.3. Currently, these BPA power charges are expected to increase only about $3 \%$ between 1996 and 2001. For this study, the demand and energy charges will be assumed to increase at $0.6 \%$ per year between 1996 and 2001. After 2001, these power costs will be assumed to increase at the same rate as other costs, at $4 \%$ per year.

Table 2.3. Projected BPA power charges for 1996

\begin{tabular}{|c|c|c|}
\hline \multicolumn{3}{|l|}{ Demand Charges } \\
\hline \multicolumn{2}{|c|}{ March - November } & $\$ 1.791 / \mathrm{kW}-$ Month \\
\hline \multicolumn{2}{|c|}{ December - February } & $\$ 4.231 / \mathrm{kW}-$ Month \\
\hline \multicolumn{3}{|c|}{ Energs /harges $/$ l. } \\
\hline \multicolumn{3}{|l|}{ March - April } \\
\hline & $6 \mathrm{am}-11 \mathrm{pm}$ & $24.81 \mathrm{mills}^{1} / \mathrm{kWh}$ \\
\hline & $11 \mathrm{pm}-6 \mathrm{am}$ & $18.36 \mathrm{mills} / \mathrm{kWh}$ \\
\hline \multicolumn{3}{|l|}{ May - July } \\
\hline & $6 a m-11 p m$ & $24.04 \mathrm{mills} / \mathrm{kWh}$ \\
\hline & $11 \mathrm{pm}-6 \mathrm{am}$ & $13.99 \mathrm{mills} / \mathrm{kWh}$ \\
\hline \multicolumn{3}{|c|}{ August - February } \\
\hline & $6 \mathrm{am}-11 \mathrm{pm}$ & $26.89 \mathrm{mills} / \mathrm{kWh}$ \\
\hline & $11 \mathrm{pm}-6 \mathrm{am}$ & $21.11 \mathrm{mills} / \mathrm{kWh}$ \\
\hline
\end{tabular}

${ }^{1} \mathrm{~A}$ mill equals one tenth of a cent

General financial assumptions are presented in Table 2.4. These assumptions are compatible with financial assumptions and cost estimates used by OPALCO in the summer 1994 .

Table 2.4. OPALCO financial Assumptions

\begin{tabular}{lc}
\hline Parameter & Assumption \\
\hline Discount rate & $8.37 \%$ \\
Levelized fixed charge rate - all capital investments & $16.2 \%$ \\
Escalation rate - all costs except BPA power charges & $4 \%$ \\
\hline
\end{tabular}

\subsection{OPALCO LOAD DATA}

Hourly Eastsound load data from March 1994 through February 1995 are presented in Appendix A. The annual integrated hourly Eastsound peak of $6,386 \mathrm{~kW}$ occurred on February 13, 1995 between 8 and 9 am. Figure 2.1 shows the February peak day load shape as well as the 
peak day load shapes for the other peak winter months, December 1994 and January 1995. Figure 2.2 presents the monthly peak demands from March 1994 through February 1995.

Review of Figures 2.1 and 2.2 as well as the Eastsound load plots in Appendix A show that the Eastsound daily peak load only exceeded $6,000 \mathrm{~kW}$ on February 13, 1995, the annual peak day, and on December 4, 1994, the December peak day. For the rest of the year the hourly Eastsound loads are significantly less than the annual peak. In addition, OPALCO personnel indicated that the 1994-1995 winter was mild. Hence, the actual annual peak load for the 1994-1995 winter was significantly less than the projected extreme annual peak load shown in Table 2.1.

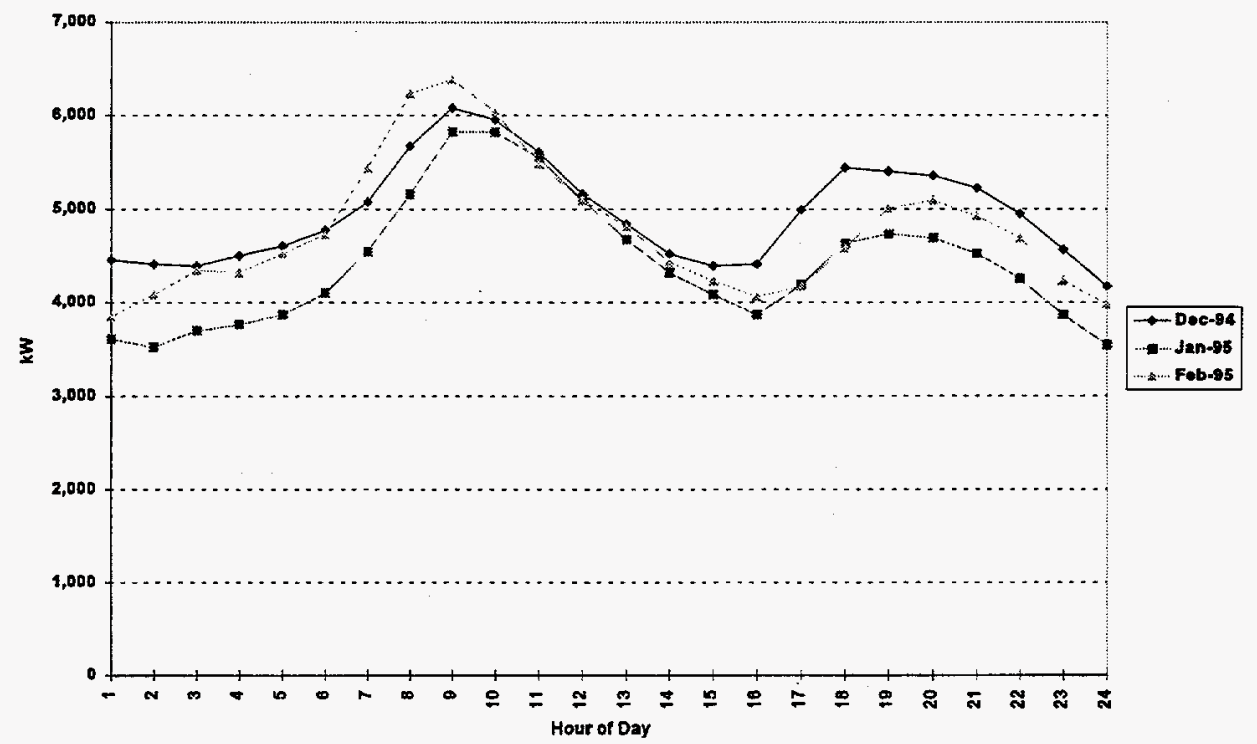

Fig. 2.1. Monthly Eastsound peak day load shape—winter 1994-1995.

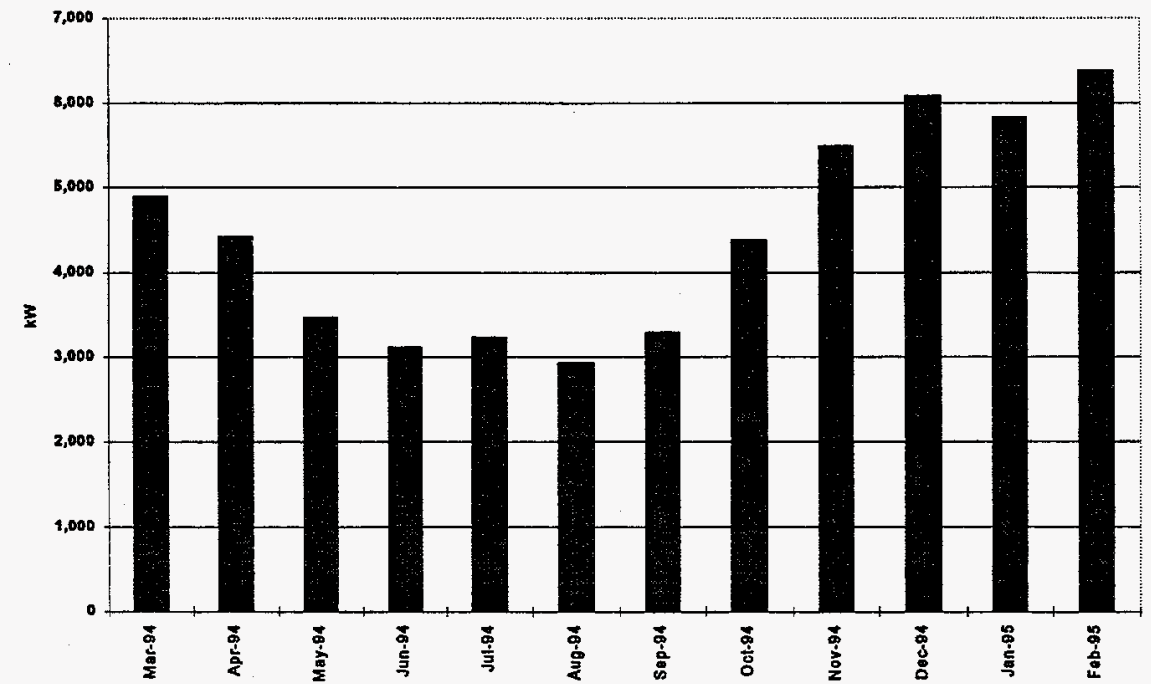

Figure 2.2. Eastsound monthly peak loads-March 1994-February 1995. 
The total coincident peak OPALCO system load for the 1994-1995 winter season was $41,289 \mathrm{~kW}$. The total system peak also occurred on February 13,1995 at the same time as the Eastsound peak load, and lasted two hours from 8-10 am. OPALCO personnel indicated that under extreme conditions the total coincident OPALCO system peak demand could have been as much as $50 \mathrm{MW}$. The Eastsound daily load shape appears to correlate nicely with the total OPALCO system load. Thus, the measured Eastsound loadshape data was also used for calculating demand charge reduction. 


\section{MW-SCALE WIND FARM PERFORMANCE}

The benefits to OPALCO associated with the integration of a MW-scale wind farm near Eastsound will vary from site to site depending on wind characteristics, and whether battery storage is applied. In this study detailed hourly wind data have been collected at two sites on Orcas Island near Eastsound to determine the relative site-specific impacts of a MW-scale wind farm on the Lopez-Eastsound distribution circuit peak loads, and determine expected monthly and annual wind farm energy production. One site is located near the top of $\mathrm{Mt}$. Constitution and the other site is located next to the OPALCO office.

The MW-scale wind farm performance was determined assuming 3-350 $\mathrm{kW}$ variable speed wind turbines are installed, each with a per $\mathrm{kW}$ power curve shown in Figure 3.1. These variable speed wind turbines cut in at low wind speeds and attain rated output when the winds exceed 26 $\mathrm{mph}$. Since the existing $25-\mathrm{kV}$ Lopez-Eastsound distribution circuit is voltage limited, variable speed wind turbines can also provide voltage support at Eastsound by supplying vars, rather than consuming vars like some wind turbine designs using induction generators.

The following sections summarize MW-scale wind farm performance from March 1994 through February 1995 at three wind data collection locations and elevations:

- Mt. Constitution at $163^{\circ}$

- Mt. Constitution at $120^{\prime}$

- OPALCO office at 133'

\subsection{WIND FARM PERFORMANCE-MT. CONSTITUTION AT 163'}

Hourly wind data were collected near the top of $\mathrm{Mt}$. Constitution at the $163^{\prime}$ level. At this location and elevation, the resulting annual average wind speed was about $12.4 \mathrm{mph}$ from March 1994 through February 1995. Figure 3.2 summarizes the average monthly wind speed at this location. In the winter months, during OPALCO's peak season, the average monthly wind speed is relatively high, ranging from about $17 \mathrm{mph}$ to over $18 \mathrm{mph}$. In the summer months, the average wind speed is low, averaging less than 10 mph. Figures B.1 and B.12 in Appendix B show the detailed hourly wind data from March 1994 through February 1995 respectively.

Resulting MW-scale wind farm performance from March 1994 through February 1995 is summarized in Table 3.1, assuming the $3-350 \mathrm{~kW}$ variable speed wind turbines, the wind power curve in Figure 3.1 and the hourly wind data gathered on Mt. Constitution at 163'. For these winds, annual wind farm energy production over the measurement period would be close to $2,000 \mathrm{MWh}$, and the annual wind farm capacity factor would be $21.2 \%$. Potential hourly wind farm performance is presented in Figures B.13 through B.24 in Appendix B.

Wind farm performance is expected to be excellent during the OPALCO winter peak season. In December 1994 the winds were the highest, and the expected wind farm energy production was $359 \mathrm{MWh}$, resulting in a monthly capacity factor of about $46 \%$. In January and February 1995, as well as November 1994, the expected wind farm capacity factor was also close to $40 \%$. During the winter months, the wind farm is expected to deliver full rated $\mathrm{kW}$ output a significant portion of the time, as shown in Figures B.21 through B.24. Figures B.13 through B.20 show that in March, April, May and October the expected wind farm energy production tapers off; and in the summer months (June through September) the expected wind farm energy production is poor.

Wind farm $\mathrm{kW}$ power output also is expected to correlate with and reduce Eastsound monthly peak loads during the OPALCO winter peak season. Figure 3.3 shows the impact of a 
MW-scale wind farm on the Eastsound hourly loads during the annual OPALCO peak load day (February 13, 1995). The Eastsound peak load between 8 and 9 a.m. is reduced $559 \mathrm{~kW}$ by the wind farm output, resulting from winds approaching $22 \mathrm{mph}$.

Table 3.1. MW-scale wind farm performance-Mt. Constitution at $163^{\prime}$

\begin{tabular}{lccc}
\hline Month & $\begin{array}{c}\text { Monthly } \\
\text { Energy } \\
\text { MWh }\end{array}$ & $\begin{array}{c}\text { Monthly } \\
\text { Capacity Factor } \\
\%\end{array}$ & $\begin{array}{c}\text { Net Peak } \\
\text { Reduction } \\
\text { kW }\end{array}$ \\
\hline Mar-94 & 161 & $20.6 \%$ & 0 \\
Apr-94 & 102 & $13.5 \%$ & 236 \\
May-94 & 84 & $10.7 \%$ & 0 \\
Jun-94 & 41 & $5.5 \%$ & 46 \\
Jul-94 & 33 & $4.2 \%$ & 29 \\
Aug-94 & 33 & $4.2 \%$ & 16 \\
Sep-94 & 74 & $9.8 \%$ & 0 \\
Oct-94 & 205 & $26.2 \%$ & 16 \\
Nov-94 & 300 & $39.7 \%$ & 236 \\
Dec-94 & 359 & $46.0 \%$ & 158 \\
Jan-95 & 291 & $37.2 \%$ & 92 \\
Feb-95 & 268 & $38.0 \%$ & 559 \\
Annual Total & $\mathbf{1 , 9 5 1}$ & $\mathbf{2 1 . 2 \%}$ & $\mathbf{5 5 9}$ \\
\hline
\end{tabular}

In December and January, the monthly peak loads would also have been reduced by the MW-scale wind farm power output, but not nearly as much. For example, on January 2, 1995, the January peak day, the monthly peak Eastsound load was $5,827 \mathrm{~kW}$, occurring between 8 and 10 a.m. as shown in Figure 3.4. During 9-10 a.m., the hourly winds were about $19 \mathrm{mph}$ and the hourly wind farm output was $343 \mathrm{~kW}$. However, during 8-9 a.m. the hourly winds were less than $13 \mathrm{mph}$ and the hourly wind farm output was only $92 \mathrm{~kW}$, resulting in a monthly peak reduction of only $92 \mathrm{~kW}$. The correlation between hourly Eastsound loads and potential MW-scale wind farm output is shown monthly from March 1994 through February 1995 in Figures B.25 through B.36 in Appendix B.

\subsection{WIND FARM PERFORMANCE-MT. CONSTITUTION AT 120'}

Hourly wind data were also collected near the top of Mt. Constitution at the $120^{\prime}$ level. For this elevation, the resulting annual average wind speed was about $11.2 \mathrm{mph}$ from March 1994 through February 1995. Wind speeds are not as high as at the 163' level discussed previously. Figure 3.5 summarizes the average monthly wind speed at this elevation. In the winter months, during OPALCO's peak season, the average monthly wind speed is again relatively high, ranging from about $14.4 \mathrm{mph}$ to $16.6 \mathrm{mph}$. In the summer months, the average wind speed is low, averaging less than $10 \mathrm{mph}$. Figures C.1 and C.12 in Appendix C show the detailed hourly wind data from March 1994 through February 1995 respectively.

Resulting MW-scale wind farm performance from March 1994 through February 1995 is summarized in Table 3.2 , again assuming the $3-350 \mathrm{~kW}$ variable speed wind turbines, the wind power curve in Figure 3.1 and the hourly wind data gathered on Mt. Constitution at 120'. For these winds, annual wind farm energy production over the measurement period would be close to 
$1,600 \mathrm{MWh}$, and the annual wind farm capacity factor would be $17.3 \%$. Potential hourly wind farm performance is presented in Figures C. 13 through C. 24 in Appendix C.

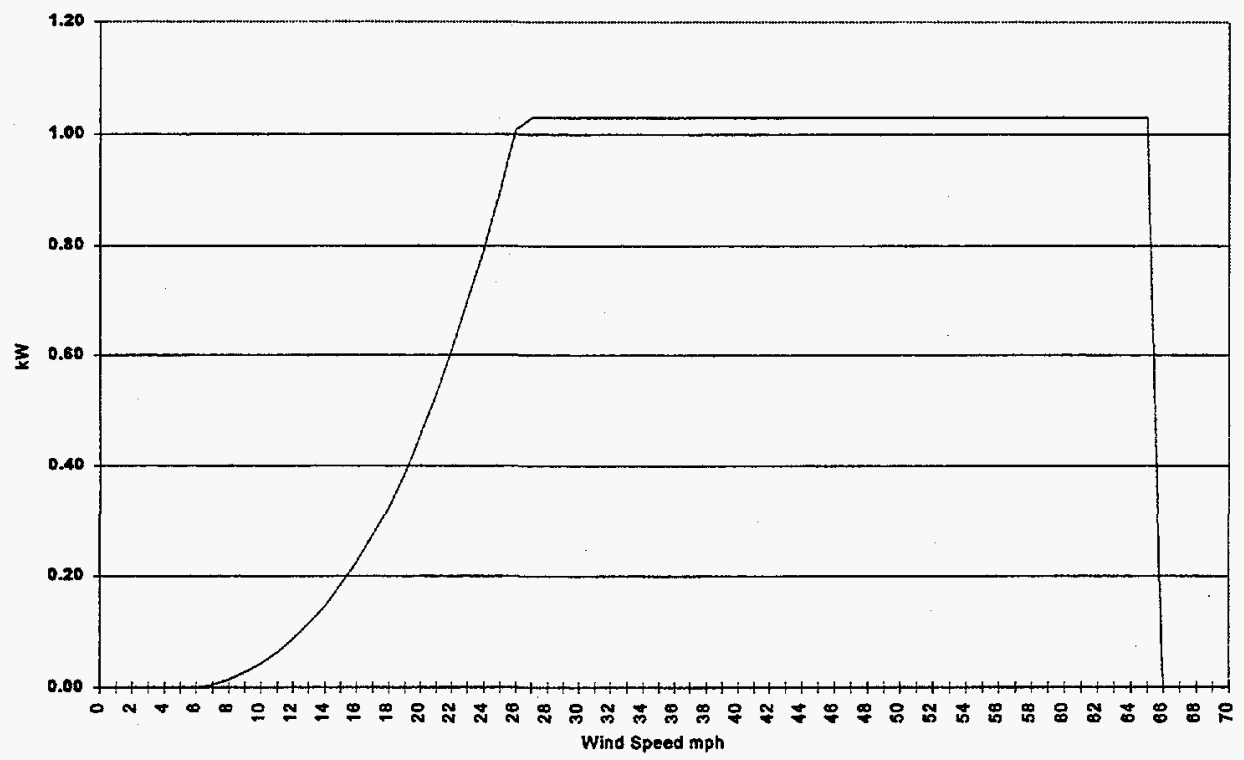

Fig. 3.1. Per $\mathrm{kW}$ power curve for variable speed turbines.

Table 3.2. MW-scale wind farm performance-Mt. Constitution at $120^{\circ}$

\begin{tabular}{lccc}
\hline Month & $\begin{array}{c}\text { Monthly } \\
\text { Energy } \\
\text { MWh }\end{array}$ & $\begin{array}{c}\text { Monthly } \\
\text { Capacity Factor } \\
\%\end{array}$ & $\begin{array}{c}\text { Net Peak } \\
\text { Reduction } \\
\mathbf{k W}\end{array}$ \\
\hline Mar-94 & 132 & $16.9 \%$ & 0 \\
Apr-94 & 84 & $11.2 \%$ & 226 \\
May-94 & 67 & $8.6 \%$ & 0 \\
Jun-94 & 35 & $4.6 \%$ & 46 \\
Jul-94 & 26 & $3.3 \%$ & 29 \\
Aug-94 & 26 & $3.3 \%$ & 6 \\
Sep-94 & 51 & $6.7 \%$ & 0 \\
Oct-94 & 165 & $21.2 \%$ & 6 \\
Nov-94 & 259 & $34.3 \%$ & 194 \\
Dec-94 & 314 & $40.2 \%$ & 135 \\
Jan-95 & 247 & $31.6 \%$ & 46 \\
Feb-95 & 188 & $26.6 \%$ & 236 \\
Annual Total & $\mathbf{1 , 5 9 4}$ & $\mathbf{1 7 . 3 \%}$ & $\mathbf{2 3 6}$ \\
\hline
\end{tabular}




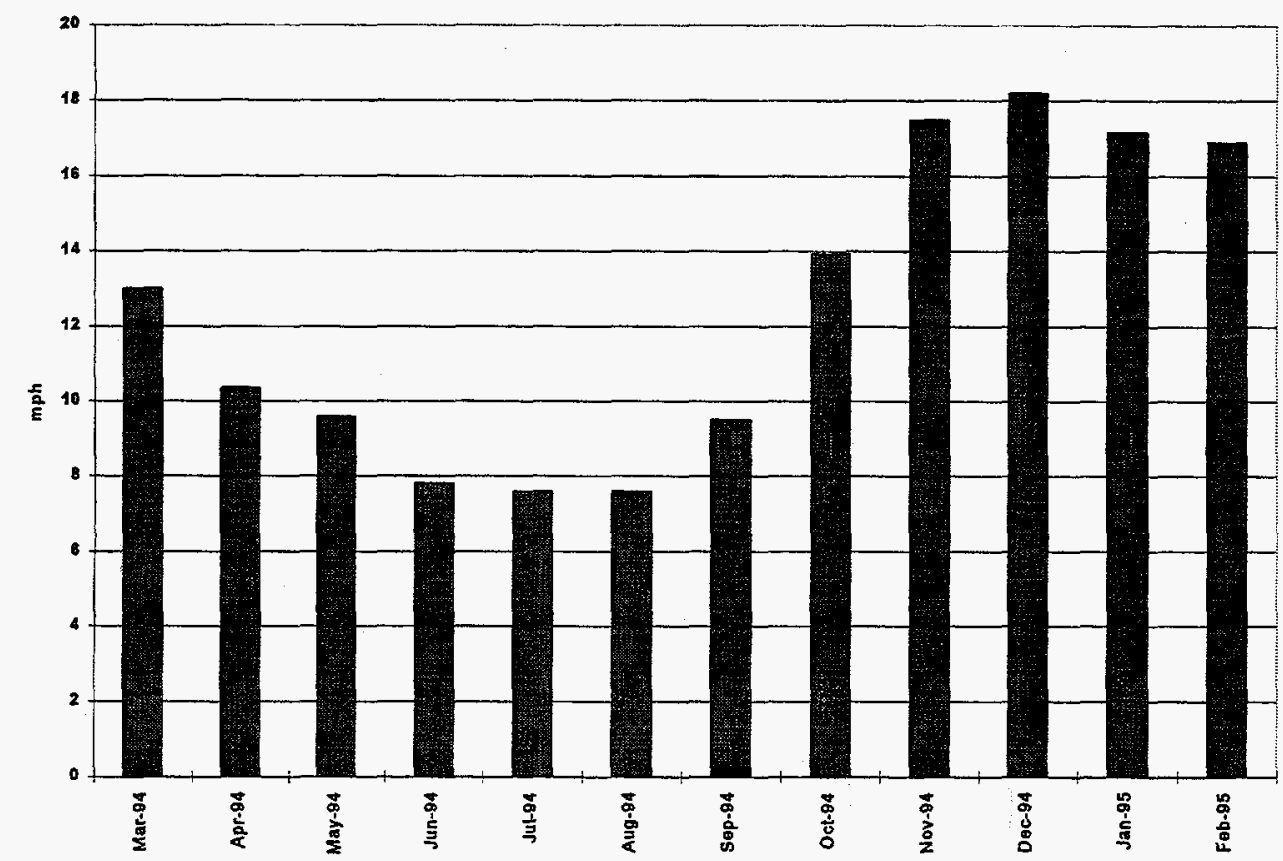

Fig. 3.2. Average monthly wind speed on Mt. Constitution at $163^{\prime}-$ March 1994 through February 1995.

Wind farm performance is again expected to be highest during the OPALCO winter peak season. In December 1994 the winds were the highest, and the expected wind farm energy production was $314 \mathrm{MWh}$, resulting in a monthly capacity factor of about $40 \%$. In January and February 1995, the expected wind farm capacity factor dropped to $31.6 \%$ and $26.6 \%$ respectively. During the winter months, the wind farm is expected to deliver full rated $\mathrm{kW}$ output for a significant portion of the time, as shown in Figures C.21 through C.24. Figures C.13 through C.20 show that in March, April, May and October the expected wind farm energy production again tapers off; and in the summer months (June through September) the expected wind farm energy production is poor.

Wind farm $\mathrm{kW}$ power output also is expected to correlate with and reduce Eastsound monthly peak loads during the OPALCO winter peak season. Figure 3.6 shows the impact of a MW-scale wind farm on the Eastsound hourly loads during the annual OPALCO peak load day (February 13, 1995). The Eastsound peak load between 8 and 9 a.m. is reduced $236 \mathrm{~kW}$ by the wind farm output, resulting from winds of about $16 \mathrm{mph}$ at this elevation.

In December and January, the monthly peak loads would also have been reduced by the MW-scale wind farm power output, but not nearly as much. For example, on January 2,1995 , the January peak day, the monthly peak Eastsound load was $5,827 \mathrm{~kW}$, occurring between 8 and 10 a.m. as shown in Figure 3.7. During $9-10$ a.m., the hourly winds were less than $13 \mathrm{mph}$ and the hourly wind farm output was $92 \mathrm{~kW}$. During 8-9 a.m. the hourly winds were about $10 \mathrm{mph}$ and the hourly wind farm output was only $46 \mathrm{~kW}$, resulting in a monthly peak reduction of only $46 \mathrm{~kW}$. The correlation between hourly Eastsound loads and potential MW-scale wind farm output is shown monthly from March 1994 through February 1995 in Figures C.25 through C.36 in Appendix C. 


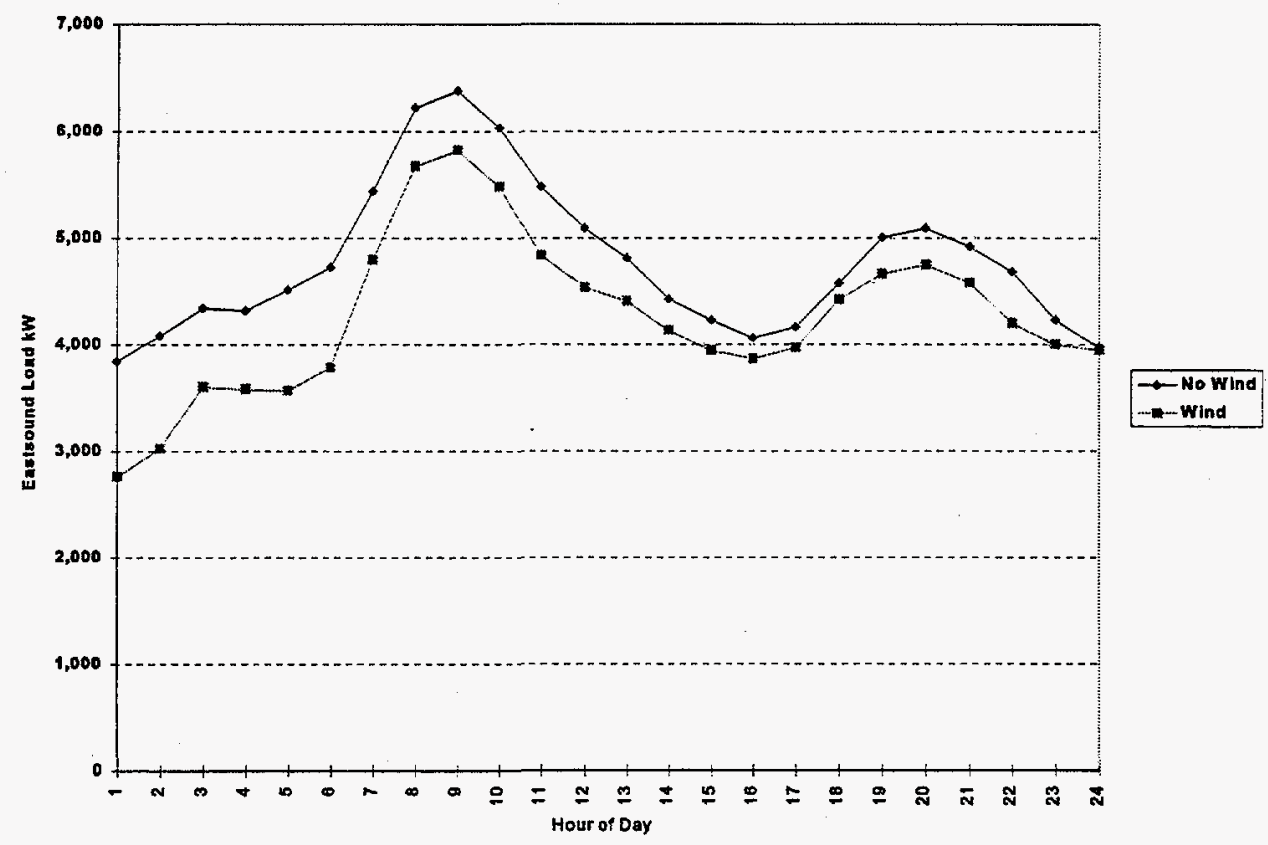

Fig. 3.3. Impact on Eastsound load during annual peak day, February 13, 1995-MW-scale wind farm located on Mt. Constitution at 163'.

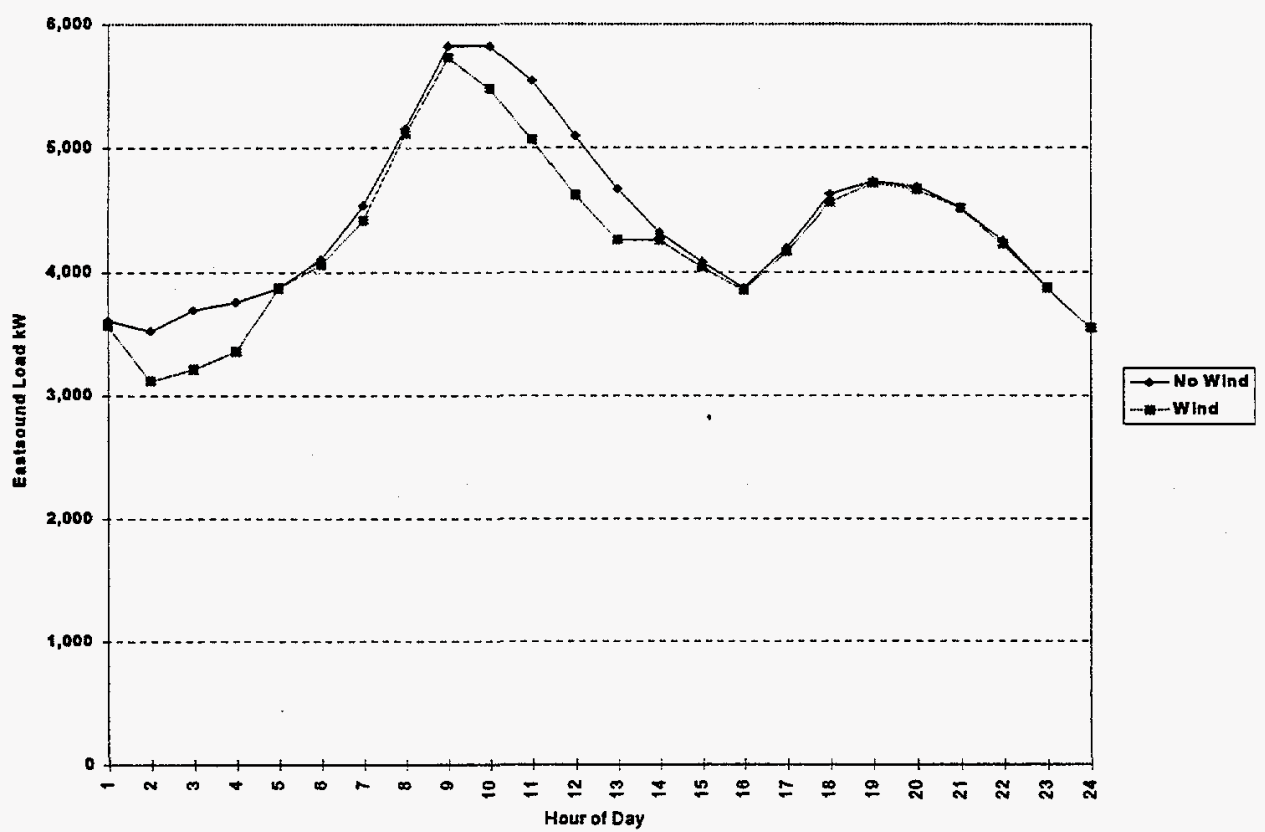

Fig. 3.4. Impact on Eastsound load during monthly peak day, January 2, 1995-MW-scale wind farm located on Mt. Constitution at 163'. 


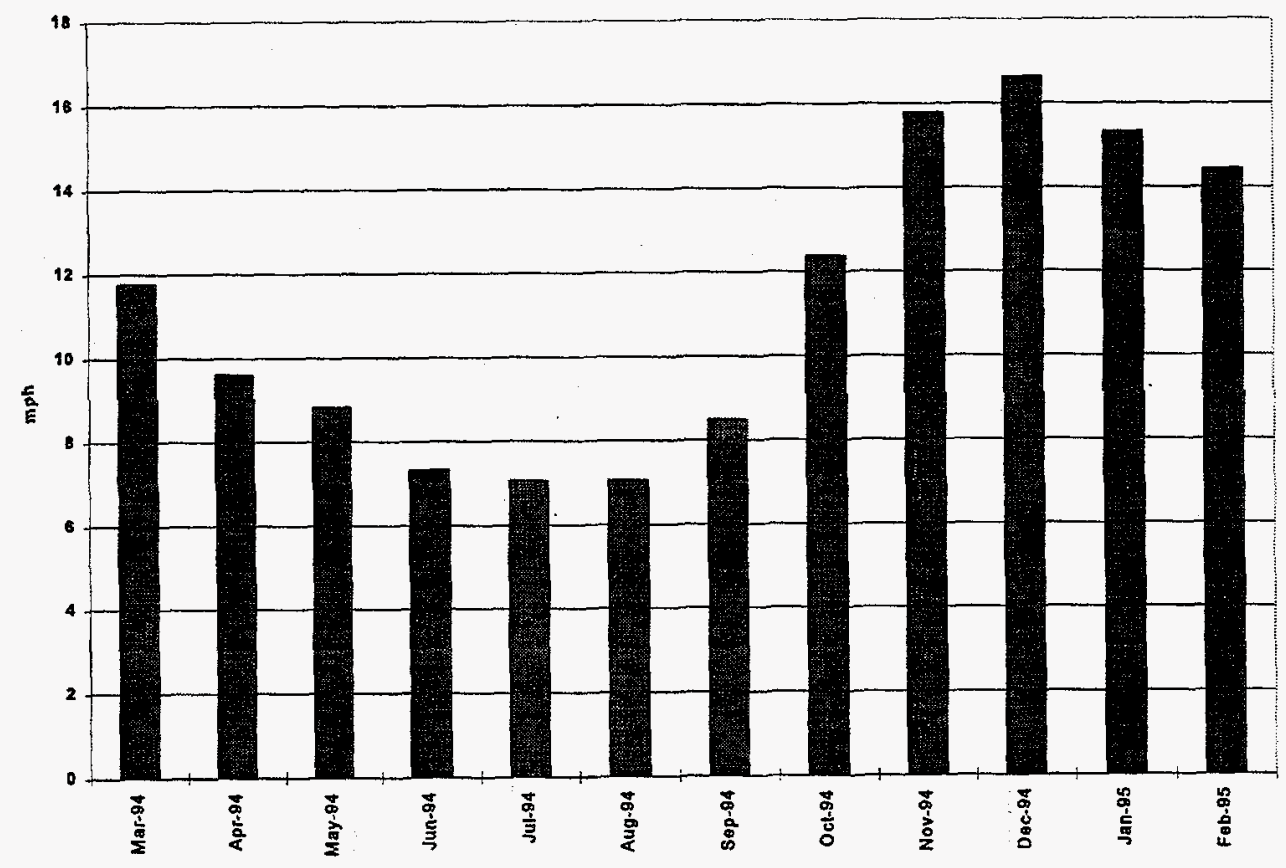

Fig. 3.5. Average monthly wind speed on Mt. Constitution at $120^{\prime}-$ March 1994 through February 1995.

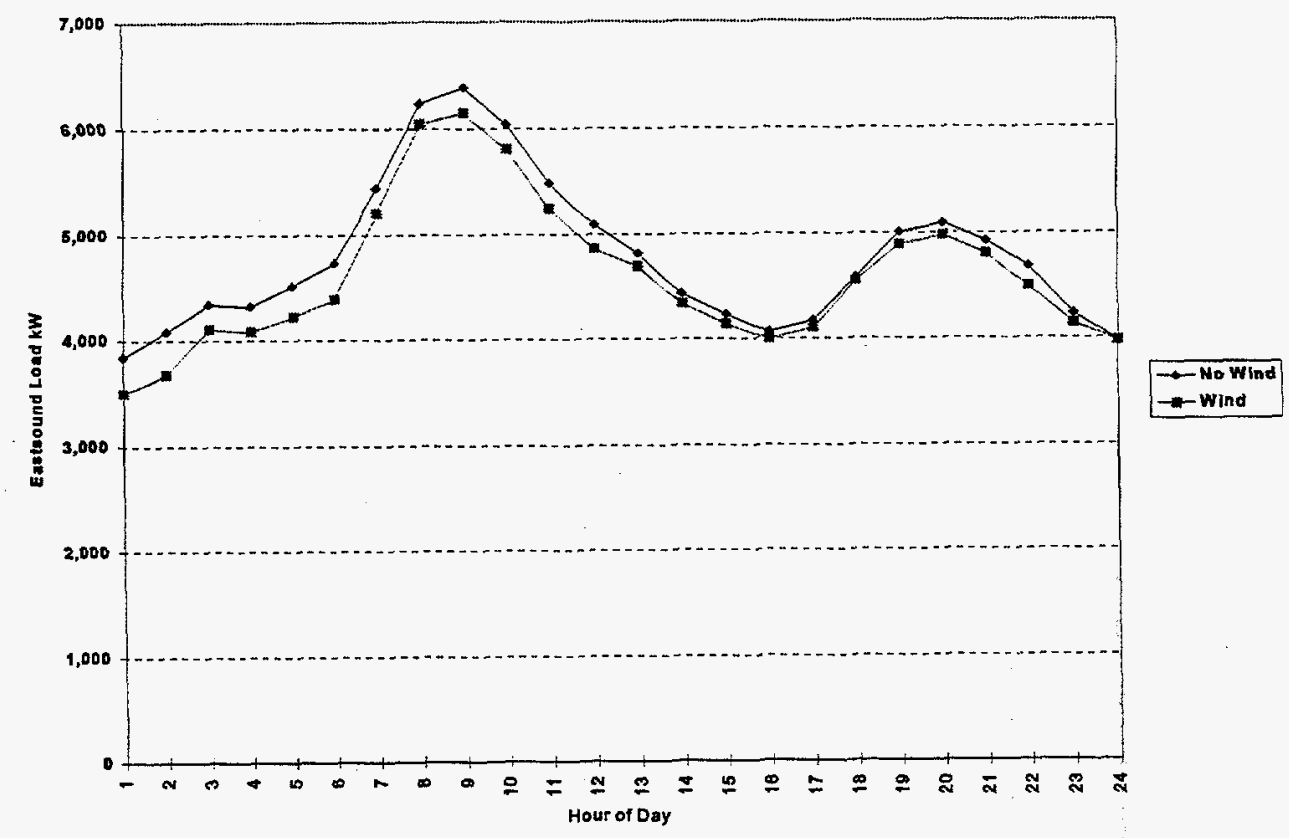

Fig. 3.6. Impact on Eastsound load during annual peak day, February 13, 1995-MW-scale wind farm located on Mt. Constitution at 120'. 


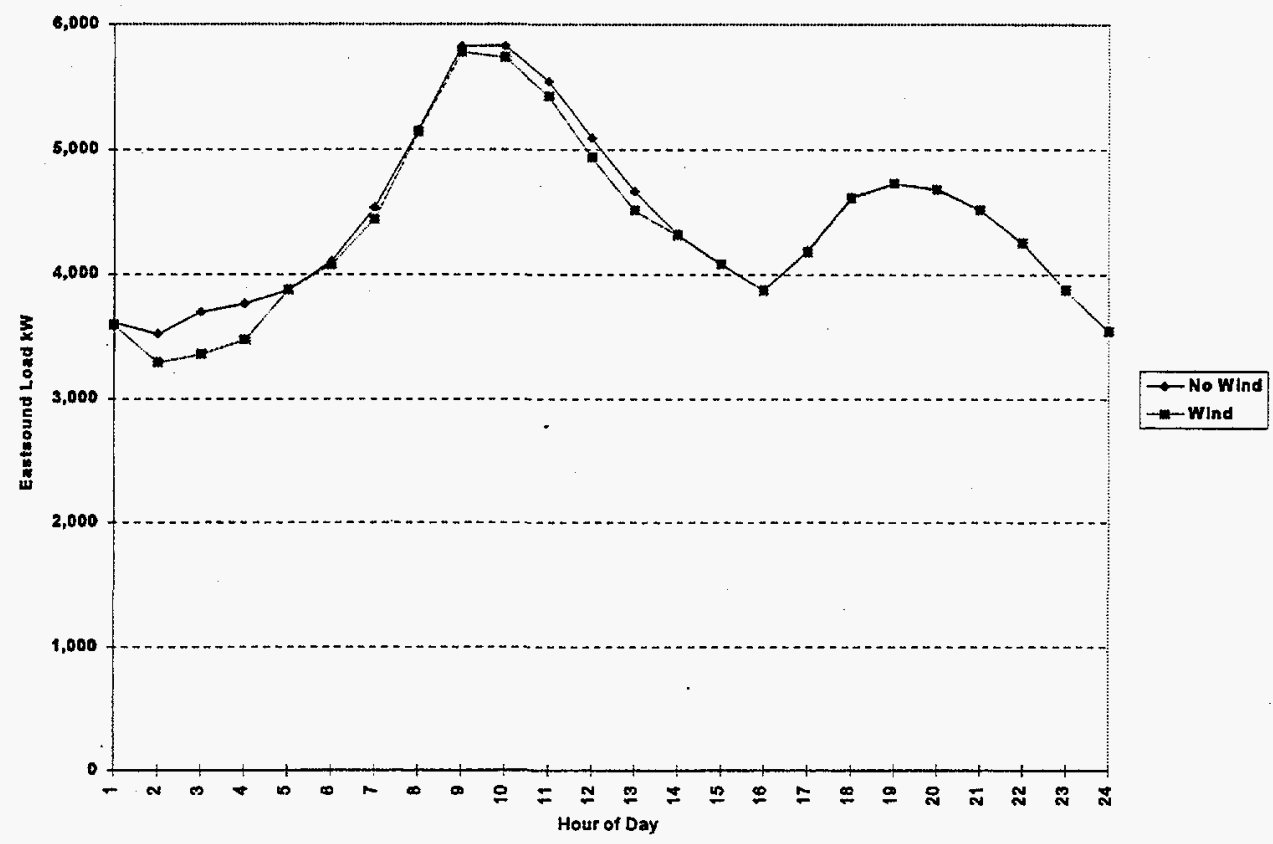

Fig. 3.7. Impact on Eastsound load during monthly peak day, January 2, 1995-MW-scale wind farm located on Mt. Constitution at 120'.

Comparing the expected wind farm performance at the Mt. Constitution site using the measured winds at $120^{\prime}$ to expected performance based on winds at $163^{\prime}$, wind farm performance is clearly superior at the higher elevation. At the 163' elevation:

- over $22 \%$ more annual energy is expected to be produced,

- the annual Eastsound peak load is expected to be reduced $559 \mathrm{~kW}$ vs. $236 \mathrm{~kW}$,

- monthly OPALCO system peak loads are reduced more.

\subsection{WIND FARM PERFORMANCE-OPALCO OFFICE AT 133'}

Hourly wind data were also collected near the OPALCO office at the $133^{\prime}$ and at the $95^{\prime}$ level. At the 133' level, the resulting annual average wind speed was about $7.3 \mathrm{mph}$ from March 1994 through February 1995. Wind speeds were significantly lower at the $95^{\prime}$ level and are not presented in this report. Figure 3.8 summarizes the average monthly wind speed at 133'. In the winter months, during OPALCO's peak season, the average monthly wind speeds are relatively low compared to Mt. Consititution, ranging from about $9.4 \mathrm{mph}$ to $10.6 \mathrm{mph}$. In the summer months, the average wind speeds are also significantly lower than the winds at Mt. Constitution, averaging about $6 \mathrm{mph}$. Figures D.1 through D.12 in Appendix D show the detailed hourly wind data from March 1994 through February 1995 respectively.

Resulting MW-scale wind farm performance from March 1994 through February 1995 is summarized in Table 3.3, again assuming the $3-350 \mathrm{~kW}$ variable speed wind turbines, the wind power curve in Figure 3.1 and the hourly wind data gathered at the OPALCO office site at 133'. 
For these winds, annual wind farm energy production over the measurement period would only be about $400 \mathrm{MWh}$, and the annual wind farm capacity factor would only be $4.5 \%$. Potential hourly wind farm performance is presented in Figures D.13 through D.24 in Appendix D.

Table 3.3. MW-scale wind farm performance-OPALCO at 133'

\begin{tabular}{lccc}
\hline Month & $\begin{array}{c}\text { Monthly } \\
\text { Energy } \\
\text { MWh }\end{array}$ & $\begin{array}{c}\text { Monthly } \\
\text { Capacity Factor } \\
\text { \% }\end{array}$ & $\begin{array}{c}\text { Net Peak } \\
\text { Reduction } \\
\mathbf{k W}\end{array}$ \\
\hline Mar-94 & 29 & $3.7 \%$ & 0 \\
Apr-94 & 12 & $1.6 \%$ & 121 \\
May-94 & 19 & $2.5 \%$ & 0 \\
Jun-94 & 12 & $1.6 \%$ & 6 \\
Jul-94 & 11 & $1.4 \%$ & 0 \\
Aug-94 & 11 & $1.4 \%$ & 0 \\
Sep-94 & 4 & $0.6 \%$ & 0 \\
Oct-94 & 30 & $3.8 \%$ & 0 \\
Nov-94 & 58 & $7.7 \%$ & 66 \\
Dec-94 & 79 & $10.1 \%$ & 172 \\
Jan-95 & 83 & $10.6 \%$ & 236 \\
Feb-95 & 67 & $9.4 \%$ & 524 \\
Annual Total & $\mathbf{4 1 6}$ & $\mathbf{4 . 5 \%}$ & $\mathbf{5 2 4}$ \\
\hline
\end{tabular}

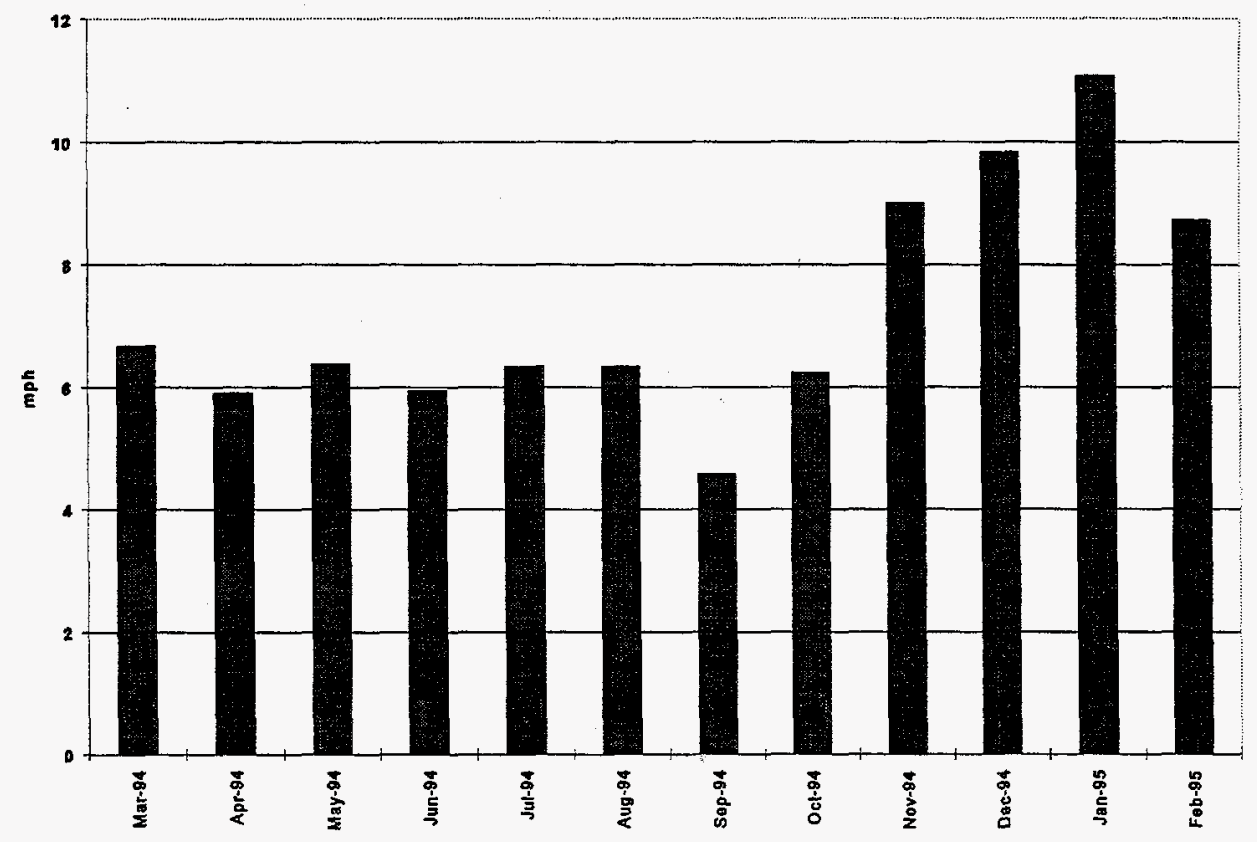

Fig. 3.8. Average monthly wind speed near OPALCO at 133'March 1994 through February 1995. 
Wind farm performance is expected to be highest during the OPALCO winter peak season. In January 1995 the winds were the highest at this site, and the expected wind farm energy production was $83 \mathrm{MWh}$, resulting in a monthly capacity factor of about $10.6 \%$. In December 1994 and February 1995, the expected wind farm capacity factor dropped to $10.1 \%$ and $9.4 \%$ respectively. During the winter months, the wind farm is expected to deliver full rated $\mathrm{kW}$ output very rarely, as shown in Figures D.22 through D.24. Figures D.13 through D.21 show that in the spring, summer and fall months the expected wind farm energy production is also poor.

However, wind farm $\mathrm{kW}$ power output at this site also is expected to correlate with and reduce Eastsound monthly peak loads during the OPALCO winter peak season. Figure 3.9 shows the impact of a MW-scale wind farm on the Eastsound hourly loads during the annual OPALCO peak load day (February 13, 1995). The Eastsound peak load between 8 and 9 a.m. of $6,386 \mathrm{~kW}$ is reduced $559 \mathrm{~kW}$ by the wind farm output to $5,827 \mathrm{~kW}$, resulting from winds of about $22 \mathrm{mph}$ measured at this site. This is the same level of peak reduction expected for a wind farm located at Mt. Constitution. However, on February 14, the Eastsound peak load between 8 and 9 a.m. of $5,891 \mathrm{~kW}$ is reduced only $29 \mathrm{~kW}$ by the wind farm output to $5,862 \mathrm{~kW}$, resulting from winds of about $9 \mathrm{mph}$ measured at this site. Hence, the net Eastsound peak load is only reduced $524 \mathrm{~kW}$ in February.

In December and January, the monthly peak loads would also have been reduced by the MW-scale wind farm power output, but not nearly as much. For example, on January 2, 1995, the monthly peak day, the monthly peak Eastsound load was $5,827 \mathrm{~kW}$, occurring between 8 and 10 a.m. as shown in Figure 3.10. During 9-10 a.m., the hourly winds were about $17.5 \mathrm{mph}$ and the hourly wind farm output was $289 \mathrm{~kW}$. During $8-9$ a.m. the hourly winds were about 16.4 mph and the hourly wind farm output was $236 \mathrm{~kW}$, resulting in a monthly peak reduction of only $236 \mathrm{~kW}$. The correlation between hourly Eastsound loads and potential MW-scale wind farm output is shown monthly from March 1994 through February 1995 in Figures D.25 through D.36 in Appendix D.

Figure 3.11 shows the expected monthly energy production for a MW-scale wind farm located at the Mt. Constitution and OPALCO office sites. Comparing the two sites, the Mt. Constitution site is clearly superior, as 4 to 5 times the energy will be produced.

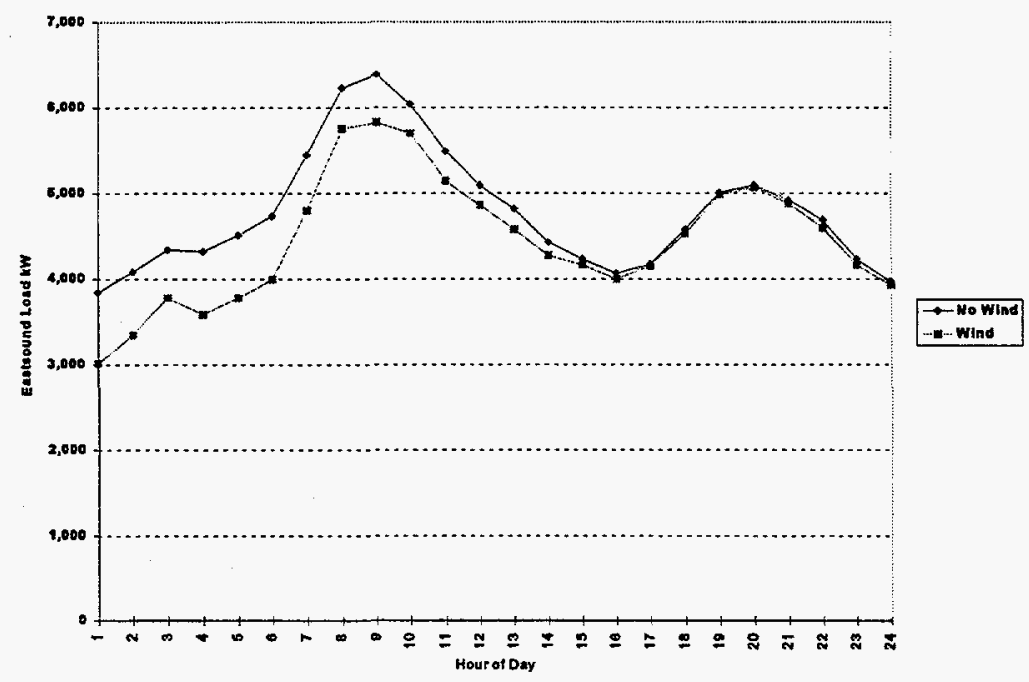

Fig. 3.9. Impact on Eastsound load during annual peak day, February 13, 1995-MW-scale wind farm located near OPALCO at 133'. 


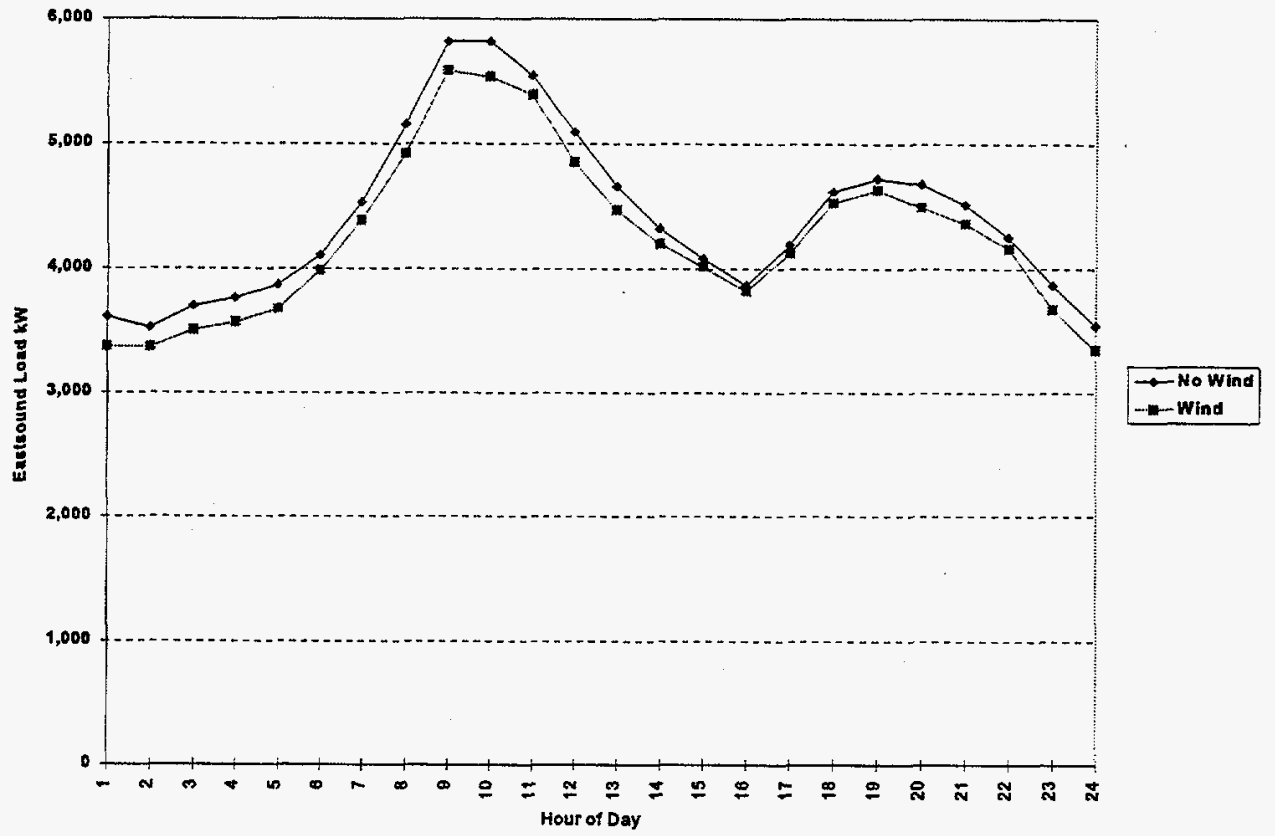

Fig. 3.10. Impact on Eastsound load during the monthly peak day, January 2, 1995-MW-scale wind farm located near OPALCO at 133'.

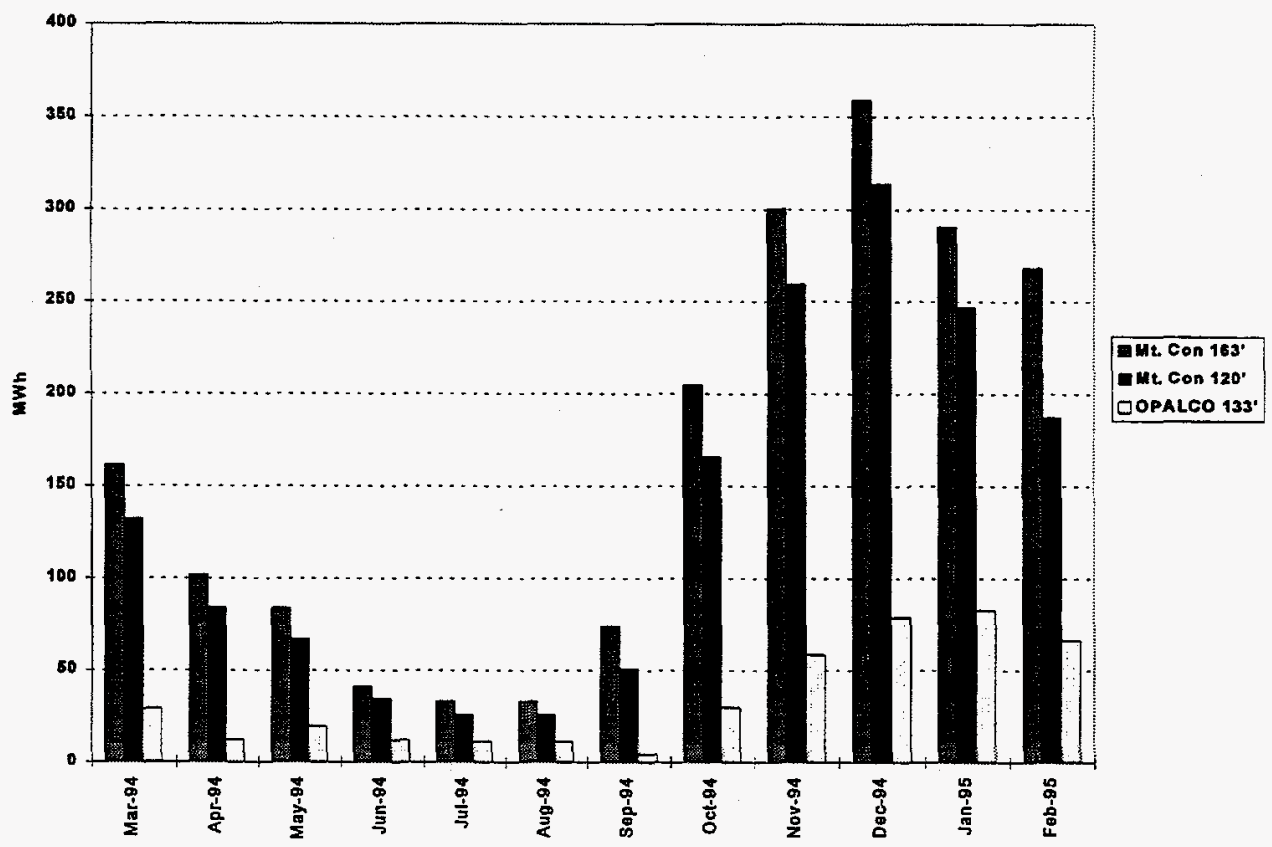

Fig. 3.11. Expected monthly MW-scale wind farm energy production. 


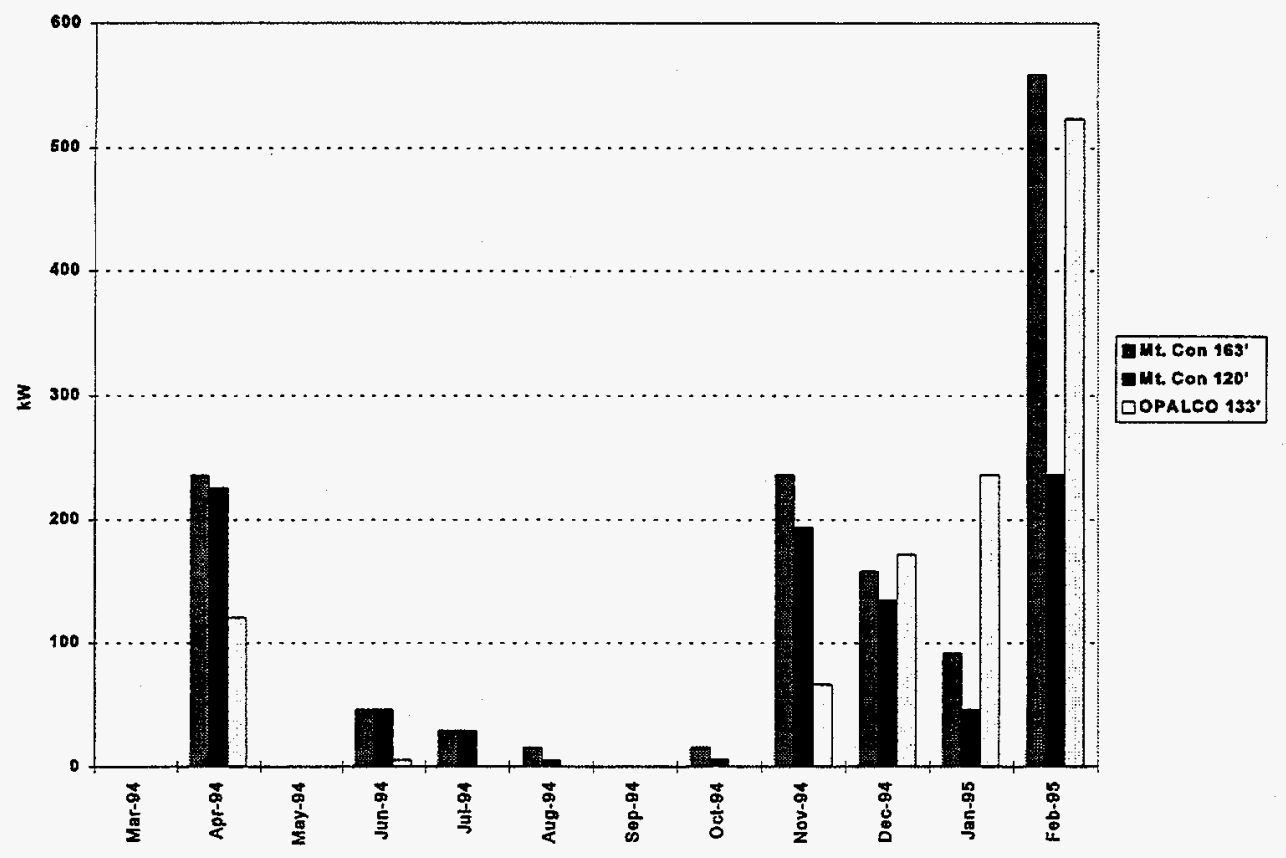

Fig. 3.12. Expected monthly peak load reduction from MW-scale wind farm.

Figure 3.12 shows the expected monthly peak load reduction for a MW-scale wind farm located at the Mt. Constitution and OPALCO office sites. Strong winds occured at both sites during the OPALCO winter peak load conditions, significantly reducing peak demands.

\subsection{WIND, TEMPERATURE AND PEAK LOAD CORRELATION}

Like most utility distribution expansion plans, the requirement to upgrade the LopezEastsound 25-kV distribution circuit to $69 \mathrm{kV}$ is based on $\mathrm{kW}$ power flows during projected extreme annual peak loading conditions. Conversations with OPALCO personnel indicate that these extreme loading conditions are expected to occur during winter storms when there is both low temperature (between 10 to $20^{\circ} \mathrm{F}$ ) and high wind. Therefore, temperature data were collected near Eastsound during the 1994-1995 winter season to observe any correlation between low temperature, high winds and peak load conditions.

Resulting hourly wind on $\mathrm{Mt}$. Constitution at $163^{\prime}$ and temperature data are plotted monthly for December 1994, January 1995 and February 1995 in Figures E.1 through E.3 in Appendix E. Review of these hourly temperature data indicated that the temperature very rarely went much below $30^{\circ} \mathrm{F}$ during the winter. On December 4,1994 between 8 and 9 a.m., when the monthly Eastsound peak load of $6,085 \mathrm{~kW}$ occurred, the temperature was about $21^{\circ}$ as shown in Figure 3.13. However, the winds were about $16 \mathrm{mph}$, relatively low compared to the winds during the annual peak day. On February 13, 1995 between 8 and 9 a.m., when the annual peak Eastsound load of $6,385 \mathrm{~kW}$ occurred, the temperature was about $27^{\circ} \mathrm{F}$, and there were high $22 \mathrm{mph}$ winds as shown in Figure 3.14. Correlation between low temperature and high winds appear to be necessary ingredients to produce extreme annual peak load conditions at Eastsound, based on these observed data. The February 13 Eastsound peak load is higher than the December 4 peak load, and high winds appear to be a significant factor. 
The projected annual extreme peak load in Table 2.1 for the $1994-1995$ winter is $7,551 \mathrm{~kW}$, which is over $1,000 \mathrm{~kW}$ above the actual annual peak load observed during this mild winter . This projected extreme load corresponds to a temperature in the $10-15^{\circ} \mathrm{F}$ range, and it appears very likely that winds will be at least as high (about $22 \mathrm{mph}$ ) as those observed during the actual winter 1994-1995 peak load conditions.

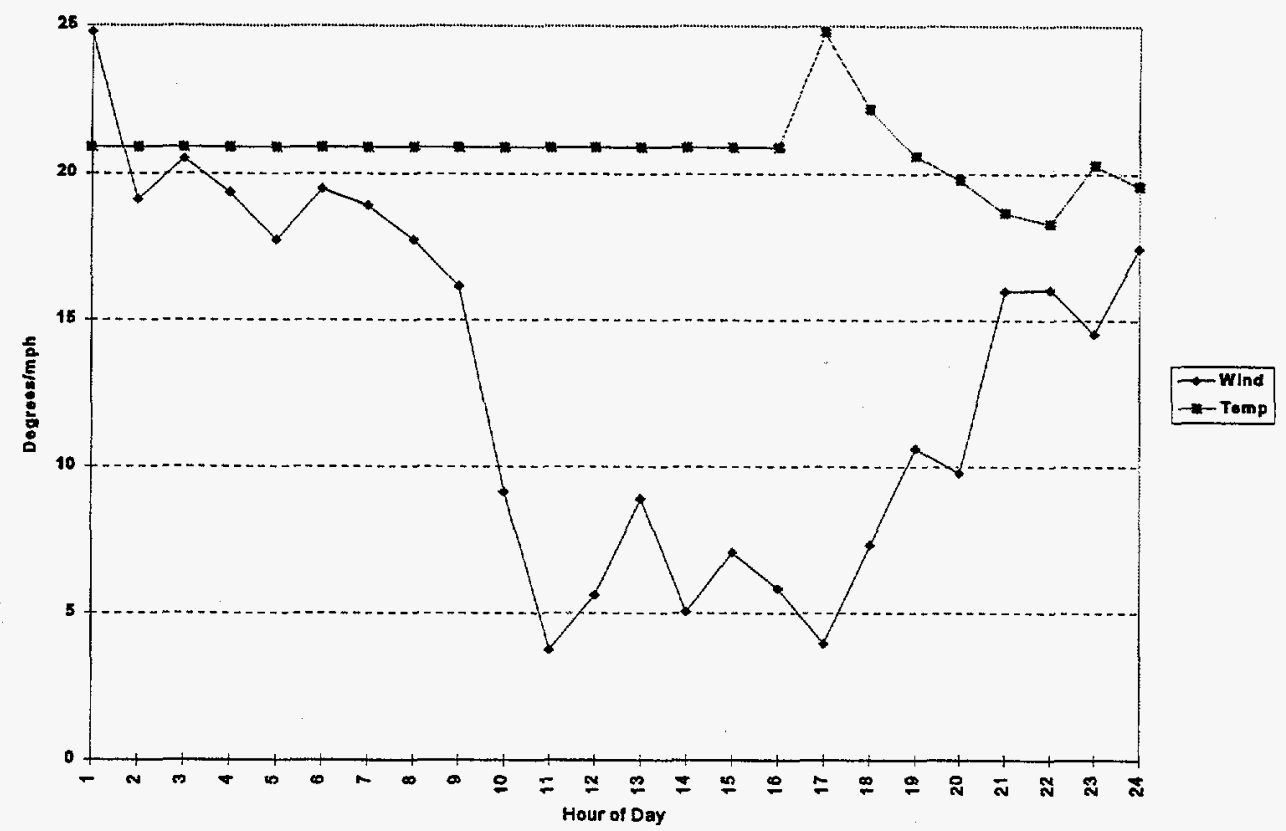

Fig. 3.13. Hourly wind and temperature on December 4, 1994.

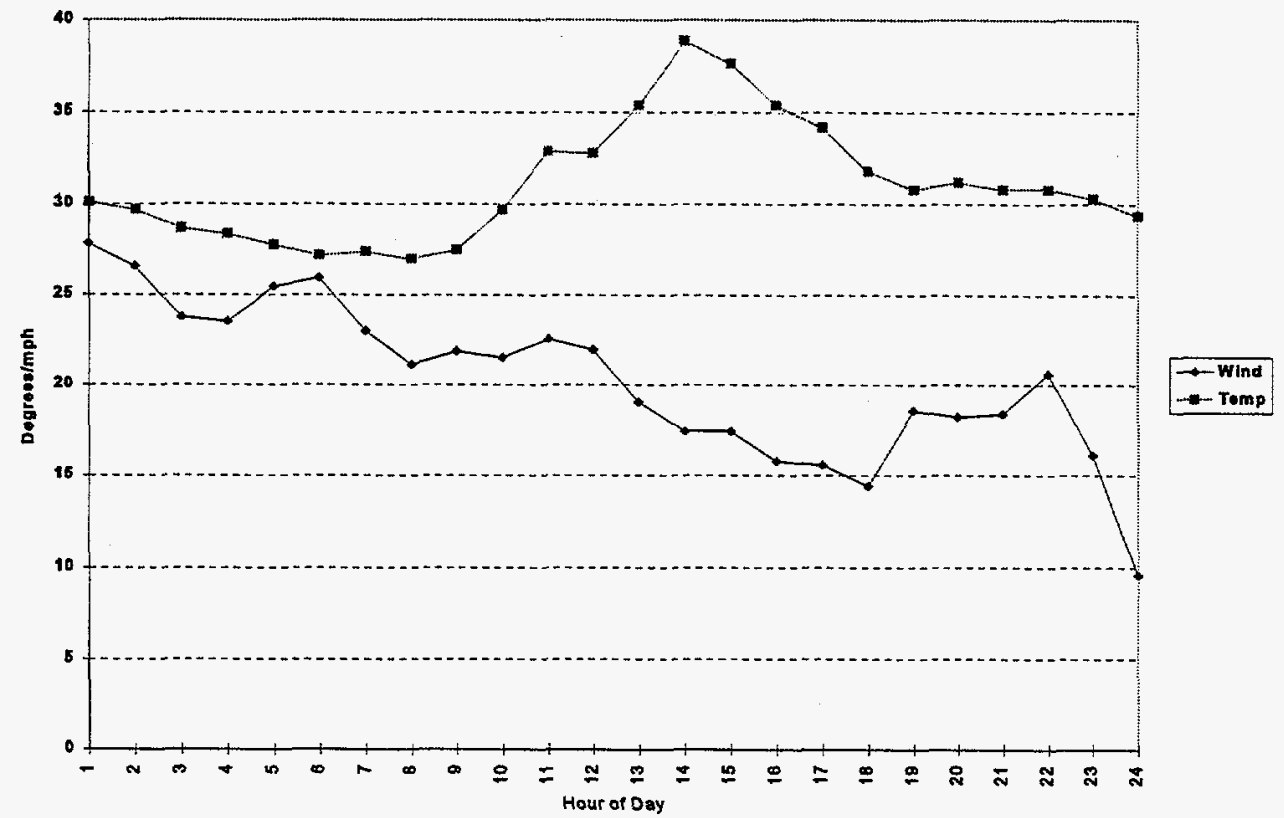

Fig. 3.14. Hourly wind and temperature for February 13, 1995. 


\subsection{BATTERY STORAGE REQUIREMENTS}

The primary application of battery storage in this study is to enhance the performance of a MW-scale wind farm installed near Eastsound. Assuming the winds on Mt. Constitution at 163', the MW-scale wind farm was able to reduce the Eastsound annual peak load $559 \mathrm{~kW}$, about one half the wind farm nameplate rating. Adding a $500-\mathrm{kW}$ battery can provide full $1,050-\mathrm{kW}$ Eastsound load peak shaving during the annual peak load condition. Adding the battery plant significantly enhances the Lopez-Eastsound circuit upgrade deferral benefit for wind cases, and shaves the annual peak $500 \mathrm{~kW}$ in battery only cases.

Battery storage daily kWh requirements to shave the February 13, 1995 annual Eastsound peak load $500 \mathrm{~kW}$ are illustrated in Figure 3.15 . On the February peak day, the battery needs to deliver $1,004 \mathrm{kWh}$ over a four hour period-349 kWh from 7 to 8 a.m., $500 \mathrm{kWh}$ from 8 to 9 a.m., and $156 \mathrm{kWh}$ from 9 to 10 a.m. This daily discharge requirement is compatible with typical $500-\mathrm{kW}$, 2-hour battery storage plant design capabilities, which will be assumed for this study.

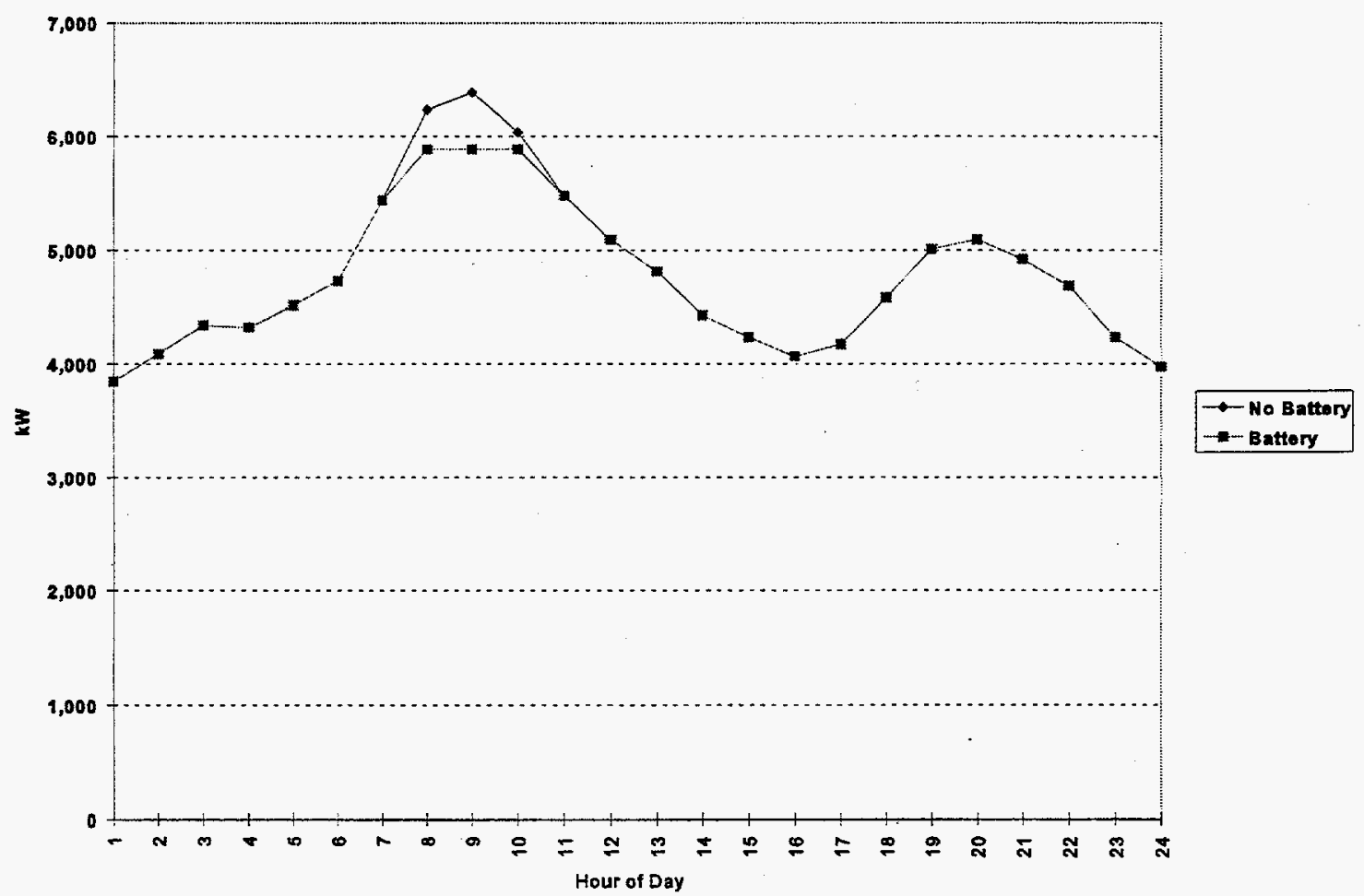

Fig. 3.15. Battery storage requirements to shave Eastsound annual peak load $500 \mathrm{~kW}$.

Since battery storage is dispatchable, the $500-\mathrm{kW}, 2$-hour battery storage plant can be used to reduce monthly OPALCO demand charges throughout the year. In the March 1994 through February 1995 time frame, a $500-\mathrm{kW}$ battery plant with 2 hours of storage was capable of reducing the total OPALCO system monthly peak demand $500 \mathrm{~kW}$ in every month but August 1994 , in which the $500-\mathrm{kW}, 2$-hour battery was able to reduce the monthly peak demand about 
$450 \mathrm{~kW}$, assuming that the Eastsound daily load shape correlates with the total OPALCO load, and that the total OPALCO load is about 7 times as large as the Eastsound load. Hence, when load growth projections are accounted for, a $500-\mathrm{kW}, 2$-hour battery plant is expected to reduce total OPALCO monthly peak demand $500 \mathrm{~kW}$ throughout the year during the study period after 1998. 


\subsection{BENEFIT-COST ANALYSIS}

\subsection{BENEFITS QUANTIFIED}

The following benefits to OPALCO are quantified in this study for a MW-scale wind farm and battery storage installed on Mt. Constitution, assuming the measured winds at 163' and battery storage located near Eastsound:

- distribution facility deferral,

- energy charge reduction,

- demand charge reduction,

- reduction in distribution losses; and

- $\quad$ EPACT production incentive.

Distribution facility deferral benefits are calculated using current OPALCO plans, costs and planning criteria to upgrade the $25-\mathrm{kV}$ Lopez-Eastsound circuit to $69 \mathrm{kV}$ in 2000 , as well as other planned future circuit capital investments in 2006 and 2008, which are presented in Section 2.1. The current schedule of circuit upgrade costs are listed in Table 2.2. Distribution facility deferral benefits are based on deferring these capital investments, by employing wind turbines and battery storage near Eastsound to reduce projected extreme Eastsound annual peak loads shown in Table 2.1.

The energy charge reduction benefits are calculated using chronological hourly wind farm energy production derived from the measured wind data for $\mathrm{Mt}$. Constitution at 163' described in Appendix B, and associated BPA time-of-day and seasonal energy charges to OPALCO presented in Table 2.3. Review of the time-of-day energy charges indicated that charging and discharging battery storage on a daily cycle to reduce annual Lopez-Eastsound circuit peaks and to reduce monthly OPALCO peak demand charges produces some small additional energy charge savings to OPALCO when batteries are employed. These small additional battery storage energy savings savings are added to the wind farm energy displacement benefits to determine total energy charge benefits.

Demand charge reduction benefits are calculated for the MW-scale wind farm based on the demand charges in Table 2.3 and the expected monthly peak load reduction in Table 3.1. These costs are adjusted appropriately for the 1 and $2-350 \mathrm{~kW}$ wind turbine addition cases. Monthly demand charge benefits for a $500-\mathrm{kW}$, 2-hour battery storage plant are determined assuming expected monthly peak load reductions of $500 \mathrm{~kW}$ as discussed in Section 3.5 .

Relative Lopez-Eastsound circuit loss benefits are calculated as part of this study, using the demand and energy charge information in Table 2.3, as well as the MW-scale wind farm energy production. In this study the relative distribution loss benefits are fairly small compared to the energy displacement and demand charge benefits. Upgrading the circuit to $69 \mathrm{kV}$ also reduces losses, and tends to cancel the loss benefits during the years that the MW-scale wind farm and battery storage plant additions are deferring the circuit upgrade.

For publicly owned utilities including OPALCO, the Energy Policy Act of 1992 (EPACT) provides for a $1.5 \notin$ per $\mathrm{kWh}$ (adjusted for inflation) renewable energy production incentive, which is applicable to the first 10 years of operation for wind turbines. ${ }^{3}$ This benefit to MWscale wind farms is included in this cost-benefit analysis, as there may be provision for payment of this incentive by 2000 . Currently, there is no provision for payment of this production incentive to publicly owned utilities. 


\subsection{WIND TURBINE AND BATTERY STORAGE COSTS}

The focus of this project is to determine economic benefits to OPALCO associated with installing a MW-scale wind farm, and battery storage to enhance wind farm performance. This study uses current OPALCO cost and system expansion assumptions presented in Section 2, and wind farm performance based on actual measured wind data near Eastsound over the past year. These up-to-date OPALCO system economic benefits are then compared with expected wind turbine and battery storage installed costs in the 1998 to 2000 time frame to determine benefitto-cost ratio, and potential economic viability.

Wind turbine and battery capital investment (CI) assumptions for this study shown in Table 4.1 are compatible with the cost assumptions used in the preliminary assessment. ${ }^{2}$ In 1998 wind turbines are assumed to cost about $\$ 1,000 / \mathrm{kW}$, and a 2 hour light-duty battery storage plant is assumed to cost about $\$ 750 / \mathrm{kW}$. Transportable battery plants may also be leased for 2 to 4 years during the Lopez-Eastsound circuit upgrade deferral period. For this study, transportable battery storage plants are assumed to be leased for 2 to 4 years at a monthly lease rate of $2.18 \%$ of the battery plant capital investment, based on a recent 4 year lease estimate from a leasing company. For wind turbines and batteries installed after 1998, capital investments and annual battery storage lease costs are assumed to escalate at $4 \%$ per year. Operation and maintenance (O\&M) costs are assumed to be capitalized as part of the wind turbine and battery storage capital investments for this study. Battery replacement is assumed every 10 years, at a capital investment of $\$ 250 / \mathrm{kW}$, escalated at $4 \%$ after 1998 .

Table 4.1. Wind turbine and battery storage capital investments

\begin{tabular}{lc}
\hline wind turbine CI plus O\&M & $\$ 1000 / \mathrm{kW}$ \\
2-hour, light-duty battery storage plant CI plus O\&M & $\$ 750 / \mathrm{kW}$ \\
battery replacement & $\$ 250 / \mathrm{kW}$ \\
battery storage plant monthly lease rate & $2.18 \%$ \\
\hline
\end{tabular}

\subsection{ECONOMIC ASSESSMENT APPROACH}

The economic assessment approach consists of performing the benefit-cost assessment using a 30 year present worth of revenue requirements (PWRR) analysis. This PWRR approach, which is compatible with the system planning techniques generally employed by both private and public utilities worldwide, consists of calculating the relative annual revenue required to support the alternative OPALCO system expansion plans with and without wind turbines and battery storage throughout the study period. Levelized annual fixed charges are calculated for the new generation and distribution system capital investments using OPALCO financial assumptions presented in Section 2. These fixed charges are added to the system operating costs to determine the annual revenue required. The total annual revenues are then discounted to the first year of the study period - 1998. All of the individual PWRR benefits and costs are then converted to equivalent $\$ / \mathrm{kW}$ capital investment values using the PWRR-capital investment relationships described in the previous ORNL report. ${ }^{2}$ Converting the PWRR results to 
equivalent $\$ / \mathrm{kW}$ values provides a clear measure of the relative magnitude of the various benefits compared with the wind turbine and battery storage capital investment requirements.

\subsection{BENEFIT-COST RESULTS}

This section presents the benefit-cost results, assuming current OPALCO planning assumptions as of early 1995, described in Section 2, and one year of measured wind data from. March 1994 through February 1995 described in Section 3.

\subsubsection{Wind Exceeds $26 \mathrm{mph}$ at Projected Extreme Annual Peak Loads}

Section 3.4 indicates that it is very likely that the winds during projected extreme peak load conditions will be at least as high as the wind (about $22 \mathrm{mph}$ ) measured during the actual 19941995 winter peak conditions. However, this was a mild winter and projected extreme peak load conditions were not attained. If the wind can be counted on to exceed $26 \mathrm{mph}$ and not exceed wind turbine cut-out speed during projected annual extreme winter peak load conditions, full nameplate $\mathrm{kW}$ capacity distribution facility deferral benefits will accrue to wind turbines installed on Mt. Constitution.

Table 4.2 presents the benefit-cost results, assuming a MW-scale wind farm consisting of 3$350 \mathrm{~kW}$ wind turbines is installed on Mt. Constitution. In this case, measured winds at $163^{\prime}$ throughout the one year measurement period are assumed. It is also assumed that winds exceeding $26 \mathrm{mph}$ can be expected during projected annual extreme peak load conditions. Adding the MW-scale wind farm can defer the upgrade of the Lopez-Eastsound circuit for 4 years from 2000 to 2004 and the currently planned 2006 and 2008 capital investments for 3 years. This results in a large $\$ 858 / \mathrm{kW}$ benefit, in addition to the energy displacement, demand charge reduction, distribution loss, and EPACT benefits. In this case, the total combined benefits are $\$ 1,443 / \mathrm{kW}$ and the benefit-to-cost ratio is 1.47 , which shows the MW-scale wind farm is a cost-effective alternative for OPALCO. Without EPACT benefits, the benefit-to-cost ratio drops to 1.32 , and the $\mathrm{MW}$-scale wind farm is still a cost-effective alternative. The levelized cost of energy of the MW-scale wind farm is $7.9 \phi / \mathrm{kWh}$.

Table 4.2. Benefit-cost results-install a MW-scale wind farm in 2000, wind speed at projected extreme annual peak exceeds $26 \mathrm{mph}$

\begin{tabular}{lcc}
\hline & PWRR $\$$ & \$/kW \\
\hline \multicolumn{1}{c}{ Benefits } & & \\
Distribution Facility Deferral & $1,462,526$ & 858 \\
Energy Charge Reduction & 629,092 & 369 \\
Demand Charge Reduction & 86,494 & 51 \\
Distribution Losses & 27,785 & 16 \\
Energy Policy Act & 253,189 & 149 \\
Total Benefits & $\mathbf{2 , 4 5 9 , 0 8 6}$ & $\mathbf{1 , 4 4 3}$ \\
Total Cost & $\mathbf{1 , 6 7 4 , 5 2 2}$ & $\mathbf{9 8 3}$ \\
Benefit-to-cost ratio & $\mathbf{1 . 4 7}$ & \\
\hline a Present worth of revenue requirements & &
\end{tabular}


In this study the largest distribution deferral benefits per $\mathrm{kW}$ of wind turbine capacity accrue over the first couple years of deferring the Lopez-Eastsound circuit $69-\mathrm{kV}$ upgrade. Hence, if the winds can be expected to exceed $26 \mathrm{mph}$ during projected extreme annual peak load, adding one or two wind turbines is even more cost-effective on a per $\mathrm{kW}$ basis. Adding 2$350 \mathrm{~kW}$ wind turbines in 2000 can defer the upgrade of the Lopez-Eastsound circuit for 3 years and the currently planned 2006 and 2008 capital investments for 2 years, resulting in a benefitto-cost ratio of 1.60 (1.45 without EPACT), as shown in Table 4.3. Adding 1-350 kW wind turbine in 2000 can defer the upgrade of the Lopez-Eastsound circuit for 2 years and the currently planned 2006 and 2008 capital investments for 1 year, resulting in a benefit-to-cost ratio of 1.96 (1.81 without EPACT) as shown in Table 4.4.

Table 4.3. Benefit-cost results-install $2-350 \mathrm{~kW}$ wind turbines in 2000 , wind speed at projected annual extreme peak exceeds $26 \mathrm{mph}$

\begin{tabular}{lcc}
\hline & PWRR $\$^{\mathrm{a}}$ & $\$ \mathrm{~kW}$ \\
\hline \multicolumn{1}{c}{ Benefits } & & \\
Distribution Facility Deferral & $1,117,511$ & 984 \\
Energy Charge Reduction & 419,604 & 369 \\
Demand Charge Reduction & 57,691 & 51 \\
Distribution Losses & 19,773 & 17 \\
Energy Policy Act & 168,877 & 149 \\
$\quad$ Total Benefits & $\mathbf{1 , 7 8 3 , 4 5 7}$ & $\mathbf{1 , 5 7 0}$ \\
Total Cost & $\mathbf{1 , 1 1 6 , 3 4 9}$ & $\mathbf{9 8 3}$ \\
Benefit-to-cost ratio & $\mathbf{1 . 6 0}$ & \\
\hline
\end{tabular}

${ }^{\text {a }}$ Present worth of revenue requirements

Table 4.4. Benefit-cost results-install $1-350 \mathrm{~kW}$ wind turbine in 2000 , wind speed at projected annual extreme peak exceeds $26 \mathrm{mph}$

\begin{tabular}{lcc}
\hline & PWRR $\$$ & $\$ / \mathrm{kW}$ \\
\hline \multicolumn{1}{c}{ Benefits } & & \\
Distribution Facility Deferral & 762,124 & 1,342 \\
Energy Charge Reduction & 209,488 & 369 \\
Demand Charge Reduction & 28,802 & 51 \\
Distribution Losses & 10,517 & 19 \\
Energy Policy Act & $\mathbf{8 4 , 3 1 2}$ & 148 \\
Total Benefits & $\mathbf{1 , 0 9 5 , 2 4 3}$ & $\mathbf{1 , 9 2 8}$ \\
Total Cost & $\mathbf{5 5 8 , 1 7 4}$ & $\mathbf{9 8 3}$ \\
Benefit-to-cost ratio & $\mathbf{1 . 9 6}$ & \\
\hline
\end{tabular}

${ }^{a}$ Present worth of revenue requirements 


\subsubsection{Measured 22 mph Wind at Projected Extreme Annual Peak Loads}

Assuming that the winds during projected extreme peak load conditions will be at least as high as the wind (about $22 \mathrm{mph}$ ) measured during the actual 1994-1995 winter peak conditions, about half of nameplate $\mathrm{kW}$ capacity distribution facility deferral benefits will accrue to wind turbines installed on Mt. Constitution.

Table 4.5 presents the benefit-cost results assuming a MW-scale wind farm is installed on Mt. Constitution in 2000, assuming wind farm performance based on the measured winds at 163' and assuming the measured $22 \mathrm{mph}$ wind during projected extreme annual peak loading conditions. Adding the MW-scale wind farm reduces the Eastsound annual peak load only 559 $\mathrm{kW}$, and defers the upgrade of the Lopez-Eastsound circuit to $69 \mathrm{kV}$ for 2 years, from 2000 to 2002 and the currently planned 2006 and 2008 capital investments for 2 years. This results in a distribution deferral benefit of $\$ 558 / \mathrm{kW}$, which is significantly less than the full distribution deferral benefits for higher winds presented in Table 4.2. In this case the total combined benefits are $\$ 1,129 / \mathrm{kW}$ and the benefit-to-cost ratio is 1.15 , which shows that the wind farm is still a cost-effective alternative for OPALCO. Without EPACT benefits, the benefit-to-cost ratio drops to 1.0. The MW-scale wind farm is still an economical alternative. However, the choice is an economic toss-up without the EPACT benefits.

Table 4.5. Benefit-cost results-install MW-scale wind farm in 2000, measured $22 \mathrm{mph}$ annual peak wind speed

\begin{tabular}{lcc}
\hline & PWRR \$ & \$/kW \\
\hline \multicolumn{1}{c}{ Benefits } & & \\
Distribution Facility Deferral & 951,140 & 558 \\
Energy Charge Reduction & 629,092 & 369 \\
Demand Charge Reduction & 58,995 & 35 \\
Distribution Losses & 30,370 & 18 \\
Energy Policy Act & 253,189 & 149 \\
$\quad$ Total Benefits & $\mathbf{1 , 9 2 2 , 7 8 6}$ & $\mathbf{1 , 1 2 9}$ \\
$\quad$ Total Cost & $\mathbf{1 , 6 7 4 , 5 2 2}$ & $\mathbf{9 8 3}$ \\
Benefit-to-cost ratio & $\mathbf{1 . 1 5}$ & \\
\hline a & &
\end{tabular}

Adding a battery storage plant near Eastsound can enhance wind turbine performance. Table 4.6 presents the benefit-cost results assuming a MW-scale wind farm is installed on Mt. Constitution in 2000 , again assuming wind farm performance based on the measured winds at $163^{\prime}$ and assuming the measured $22 \mathrm{mph}$ wind during projected extreme annual peak loading conditions. In addition, a $500-\mathrm{kW}, 2$-hour battery plant is assumed to be leased for 2 years from 2002 through 2003 . Adding the $\mathrm{MW}$-scale wind farm plus the battery storage plant can reduce the Eastsound annual peak load 1,050 kW, and defer the upgrade of the Lopez-Eastsound circuit to $69 \mathrm{kV}$ for 4 years, from 2000 to 2004 rather than 2 years. This results in a much larger distribution deferral benefit of $\$ 750 / \mathrm{kW}$, compared to adding the MW-scale wind farm by itself. The battery storage plant also increases the demand charge reduction benefits compared to wind 
alone by reducing OPALCO monthly demand charges during the 2 year lease. In addition, the leased battery storage backs up the wind farm by providing $500-\mathrm{kW}$ Eastsound annual peak demand reduction capability, if for some reason there are low winds during the annual peak. Leasing a $500-\mathrm{kW}$ battery storage plant enhances the MW-scale wind farm benefits more than the incremental increase in costs. In this case, the total combined benefits are $\$ 1,330 / \mathrm{kW}$ and the benefit-to-cost ratio is 1.24 . This shows that the wind farm plus leased battery plant may be a more cost-effective alternative for OPALCO than wind alone, if the wind farm can not attain full distribution benefits. Without EPACT benefits, the benefit-to-cost ratio drops to 1.10 , and the MW-scale wind farm plus leased $500-\mathrm{kW}$ battery plant is still a cost-effective alternative.

A $500-\mathrm{kW}$ battery storage plant could be purchased rather than leased, and provide enhanced wind farm benefits throughout the study period. In this case, the Lopez-Eastsound circuit upgrade is again deferred to 2004. In addition, the planned Lopez-Eastsound circuit upgrades in 2006 and 2008 are deferred 3 years rather than 2 years, monthly OPALCO demand charges are reduced throughout the study period, and the battery storage plant can be used to back up the wind farm during any unforeseen low wind periods. The resulting combined benefits are $\$ 1,543 / \mathrm{kW}$, and the benefit-to-cost ratio is 1.12 , as shown in Table 4.7 . This is still cost-effective alternative for OPALCO. However, the benefit-to-cost ratio for leasing the battery storage plant for 2 years shown in Table 4.6 is significantly higher than purchasing the battery storage plant. Hence, leasing a battery storage plant appears more economically attractive, unless other distribution deferral benefits can be accrued over the battery plant life.

Table 4.6. Benefit-cost results-install a MW-scale wind farm in 2000 and lease a $500-\mathrm{kW}$ battery storage plant in 2002 , measured $22 \mathrm{mph}$ annual peak wind speed

\begin{tabular}{lcc}
\hline & PWRR $\$$ a & $\$ / \mathrm{kW}$ \\
\hline \multicolumn{1}{c}{ Benefits } & $1,278,633$ & 750 \\
Distribution Facility Deferral & 629,149 & 369 \\
Energy Charge Reduction & 78,215 & 46 \\
Demand Charge Reduction & 26,717 & 16 \\
Distribution Losses & 253,189 & 149 \\
Energy Policy Act & $\mathbf{2 , 2 6 5 , 9 0 3}$ & $\mathbf{1 , 3 3 0}$ \\
$\quad$ Total Benefits & $\mathbf{1 , 8 2 2 , 3 8 1}$ & $\mathbf{1 , 0 7 0}$ \\
Total Cost & $\mathbf{1 . 2 4}$ & \\
Benefit-to-cost ratio & & \\
\hline
\end{tabular}

${ }^{\text {a }}$ Present worth of revenue requirements 
Table 4.7. Benefit-cost results-install a MW-scale wind farm in 2000

and purchase a $500-\mathrm{kW}$ battery storage plant in 2002 , measured $22 \mathrm{mph}$ annual peak wind speed

\begin{tabular}{lcc}
\hline & PWRR S $^{\mathrm{a}}$ & \$/kW \\
\hline \multicolumn{1}{c}{ Benefits } & \\
Distribution Facility Deferral & $1,462,526$ & 858 \\
Energy Charge Reduction & 629,621 & 370 \\
Demand Charge Reduction & 249,636 & 147 \\
Distribution Losses & 34,120 & 20 \\
Energy Policy Act & 253,189 & 149 \\
Total Benefits & $\mathbf{2 , 6 2 9 , 0 9 2}$ & $\mathbf{1 , 5 4 3}$ \\
Total Cost & $\mathbf{2 , 3 4 6 , 8 6 3}$ & $\mathbf{1 , 3 7 7}$ \\
Benefit-to-cost ratio & $\mathbf{1 . 1 2}$ & \\
\hline present worth of revenue requirements & &
\end{tabular}

\subsubsection{Battery Storage Only}

Battery storage can also be added near Eastsound without the wind farm, and defer the Lopez-Eastsound circuit upgrade to $69 \mathrm{kV}$. A transportable 500-kW, 2-hour battery storage plant could be leased for 2 years from 2000 through 2001, reducing Eastsound annual peak demand $500 \mathrm{~kW}$, and deferring the upgrade of the Lopez-Eastsound circuit to $69 \mathrm{kV}$ from 2000 to 2002. During the 2 year lease period, the battery plant can reduce OPALCO monthly demand charges, and there is a small reduction in energy charges. In this case, the total combined benefits are $\$ 727 / \mathrm{kW}$ and the benefit-to-cost ratio is 3.68 , as shown in Table 4.8 . Practically all of the benefits are based on deferring the Lopez-Eastsound circuit upgrade. The large benefitto-cost ratio results from the relatively low lease costs over the 2 year period.

If the battery storage plant is purchased in 2000 rather than leased, the resulting total combined benefits are $\$ 1,418 / \mathrm{kW}$ and the benefit-to-cost ratio is 1.52 , as shown in Table 4.9. In this case, the Lopez-Eastsound circuit upgrade is again deferred to 2002. In addition, the planned Lopez-Eastsound circuit upgrades in 2006 and 2008 are deferred 2 years, and monthly OPALCO demand charges are reduced throughout the study period. 
Table 4.8. Benefit-cost results-lease a $500-\mathrm{kW}$ battery storage plant in 2000 for 2 years

\begin{tabular}{lcc}
\hline & PWRR S $^{\mathbf{a}}$ & $\mathbf{S / k W}$ \\
\hline \multicolumn{1}{c}{ Benefits } & & \\
Distribution Facility Deferral & 567,669 & 700 \\
Energy Charge Reduction & 62 & 0 \\
Demand Charge Reduction & 22,355 & 28 \\
Total Benefits & $\mathbf{5 9 0 , 0 8 6}$ & $\mathbf{7 2 7}$ \\
Total Cost & $\mathbf{1 6 0 , 5 4 5}$ & $\mathbf{1 9 8}$ \\
Benefit-to-cost ratio & $\mathbf{3 . 6 8}$ & \\
\hline a present worth of revenue requirements & &
\end{tabular}

Table 4.9. Benefit-cost results-purchase a 500-kW battery storage plant in 2000

\begin{tabular}{lcc}
\hline & PWRR \$ $^{\mathbf{a}}$ & \$/kW \\
\hline \multicolumn{1}{c}{ Benefits } & & \\
Distribution Facility Deferral & 951,140 & 1,172 \\
Energy Charge Reduction & 529 & 1 \\
Demand Charge Reduction & 190,641 & 235 \\
Distribution Losses & 8,414 & 10 \\
Total Benefits & $\mathbf{1 , 1 5 0 , 7 2 5}$ & $\mathbf{1 , 4 1 8}$ \\
Total Cost & $\mathbf{7 5 7 , 3 3 7}$ & $\mathbf{9 3 3}$ \\
Benefit-to-cost ratio & $\mathbf{1 . 5 2}$ & \\
\hline a present worth of revenue requirements & &
\end{tabular}




\subsection{OTHER POTENTIAL APPLICATIONS}

\subsection{ASSUMPTIONS}

It is expected that many other potential applications of wind and storage similar to this OPALCO application can be identified. Many other winter peaking utilities throughout the northern United States have distribution circuits with winter peak daily load shapes similar to the OPALCO system load shapes in this study. In many cases it is likely that these extreme annual winter peak design loads will also occur during coincident low temperature and high wind ambient conditions. Thus, distribution facility deferral benefits, energy and demand charge reduction benefits, and other benefits similar to those identified in this study may apply to wind and storage plants integrated into these utility systems.

Distribution facility upgrade costs for these other potential utility applications are expected to be of the same order of magnitude as those identified in this study. However, energy and demand charge reduction benefits for other utilities who purchase their power, and energy displacement and capacity value benefits for utilities that generate their own power will vary significantly throughout the United States.

The demand and energy charges for OPALCO shown in Table 2.3 are relatively low compared to corresponding demand and energy charges expected for other utilities located in other regions of the United States, as shown in the recent ORNL report. ${ }^{1-2}$ For example, in this previous study, the energy charges for the winter peaking Green Mountain Power Company located in Vermont ranged from about $\$ 56 / \mathrm{MWh}$ during on-peak periods to about $\$ 28 / \mathrm{MWh}$ during off-peak periods in 1998. In addition, monthly demand charges based on the cost of installing a combustion turbine at approximately $\$ 500 / \mathrm{kW}$ would be about $\$ 7 / \mathrm{kW}$-month.

In this section, the OPALCO benefit-cost analysis in Section 4 in recalculated to show the likely order of magnitude of benefit-cost ratio for other similar wind and storage applications on other utility systems with higher marginal energy and demand costs. In these calculations, all of the Section 4 benefit-cost assumptions remain the same except that the energy and demand charge assumptions in Table 2.3 are replaced with those in Table 5.1. The monthly demand charges are based on the cost of a combustion turbine as described above. The on-peak and offpeak energy charges are based on the range of on-peak and off-peak energy charges used for Green Mountain Power in the previous study. In addition, the demand and energy charges in Table 5.1 are assumed to increase at $4 \%$ per year throughout the study period, like all other costs, as described in Table 2.4 .

Table 5.1. Assumed Demand and Energy Charges for 1998

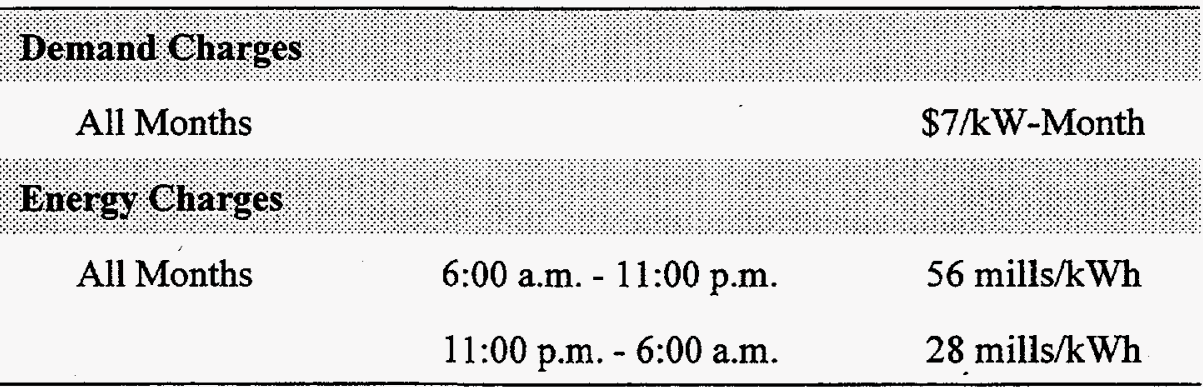




\subsection{BENEFIT-COST RESULTS}

This section presents the recalculation of the benefit-cost results presented in Section 4.4, again assuming current OPALCO planning assumptions as of early 1995 described in Section 2, one year of measured wind data from March 1994 through February 1995 described in Section 3, and the above modified energy and demand charge assumptions described in Section 5.1.

\subsubsection{Wind Exceeds $26 \mathrm{mph}$ at Projected Extreme Annual Peak Loads}

In this case, if the wind can be counted on to exceed $26 \mathrm{mph}$ and not exceed wind turbine cut-out speed during projected annual extreme winter peak load conditions, full nameplate $\mathrm{kW}$ capacity distribution facility deferral benefits will accrue to wind turbines.

Table 5.2 presents the benefit-cost results, assuming a MW-scale wind farm consisting of 3$350 \mathrm{~kW}$ wind turbines is installed. In this case, the total combined benefits are $\$ 1,929 / \mathrm{kW}$ and the benefit-to-cost ratio is 1.96 , which shows the $\mathrm{MW}$-scale wind farm is a highly cost-effective alternative. Without EPACT benefits, the benefit-to-cost ratio drops to 1.81, and the MW-scale wind farm is still a highly cost-effective alternative.

Table 5.2. Benefit-cost results-install a MW-scale wind farm in 2000, wind speed at projected extreme annual peak exceeds $26 \mathrm{mph}$

\begin{tabular}{lcc}
\hline & PWRR $^{\mathrm{a}}$ & \$/kW \\
\hline \multicolumn{1}{c}{ Benefits } & & \\
Distribution Facility Deferral & $1,462,526$ & $\mathbf{8 5 8}$ \\
Energy Charge Reduction & $1,322,837$ & 776 \\
Demand Charge Reduction & 189,588 & 111 \\
Distribution Losses & 58,842 & 35 \\
Energy Policy Act & 253,189 & 149 \\
$\quad$ Total Benefits & $\mathbf{3 , 2 8 6 , 9 8 2}$ & $\mathbf{1 , 9 2 9}$ \\
\multicolumn{1}{c}{ Total Cost } & $\mathbf{1 , 6 7 4 , 5 2 2}$ & $\mathbf{9 8 3}$ \\
Benefit-to-cost ratio & $\mathbf{1 . 9 6}$ & \\
\hline resent worth of revenue requirements & &
\end{tabular}

In this study the largest distribution deferral benefits per $\mathrm{kW}$ of wind turbine capacity accrue over the first couple years. Hence, if the winds can be expected to exceed $26 \mathrm{mph}$ during projected extreme annual peak load, adding one or two wind turbines is even more cost-effective on a per $\mathrm{kW}$ basis. Adding $2-350 \mathrm{~kW}$ wind turbines in 2000 results in a benefit-to-cost ratio of 2.09 (1.94 without EPACT), as shown in Table 5.3. Adding $1-350 \mathrm{~kW}$ wind turbine in 2000 , results in a benefit-to-cost ratio of 2.46 (2.31 without EPACT) as shown in Table 5.4.

Comparing these results with the corresponding OPALCO benefit-cost results in Section 4.4.1, other potential applications of wind with higher energy and demand charges can produce significantly higher benefit-cost ratios:

- $\quad 1.96$ vs. 1.47 for a MW-scale wind farm containing $3-350 \mathrm{~kW}$ wind turbines,

- $\quad 2.09$ vs 1.60 for $2-350 \mathrm{~kW}$ wind turbines; and

- 2.46 vs 1.96 for $1-350 \mathrm{~kW}$ wind turbines. 
Table 5.3. Benefit-cost results-install $2-350 \mathrm{~kW}$ wind turbines in 2000 , wind speed at projected annual extreme peak exceeds $26 \mathrm{mph}$

\begin{tabular}{lcc}
\hline & PWRR $\$^{\mathrm{a}}$ & $\mathbf{\$} / \mathrm{kW}$ \\
\hline \multicolumn{1}{c}{ Benefits } & & \\
Distribution Facility Deferral & $1,117,511$ & 984 \\
Energy Charge Reduction & $\mathbf{8 8 2 , 3 3 2}$ & $\mathbf{7 7 7}$ \\
Demand Charge Reduction & 126,455 & 111 \\
Distribution Losses & 41,875 & 37 \\
Energy Policy Act & 168,877 & 149 \\
Total Benefits & $\mathbf{2 , 3 3 7 , 0 5 1}$ & $\mathbf{2 , 0 5 8}$ \\
Total Cost & $\mathbf{1 , 1 1 6 , 3 4 9}$ & $\mathbf{9 8 3}$ \\
Benefit-to-cost ratio & $\mathbf{2 . 0 9}$ & \\
\hline
\end{tabular}

a Present worth of revenue requirements

Table 5.4. Benefit-cost results-install $1-350 \mathrm{~kW}$ wind turbine in 2000 , wind speed at projected annual extreme peak exceeds $26 \mathrm{mph}$

\begin{tabular}{lcc}
\hline & PWRR $^{\text {a }}$ & \$/kW \\
\hline \multicolumn{1}{c}{ Benefits } & & \\
Distribution Facility Deferral & 762,124 & 1,342 \\
Energy Charge Reduction & 440,505 & 776 \\
Demand Charge Reduction & 63,133 & 111 \\
Distribution Losses & 22,273 & 39 \\
Energy Policy Act & $\mathbf{8 4 , 3 1 2}$ & 148 \\
$\quad$ Total Benefits & $\mathbf{1 , 3 7 2 , 3 4 7}$ & $\mathbf{2 , 4 1 6}$ \\
$\quad$ Total Cost & $\mathbf{5 5 8 , 1 7 4}$ & $\mathbf{9 8 3}$ \\
Benefit-to-cost ratio & $\mathbf{2 . 4 6}$ & \\
\hline
\end{tabular}

${ }^{\text {a }}$ Present worth of revenue requirements

\subsubsection{Measured 22 mph Wind at Projected Extreme Annual Peak Loads}

Assuming that the winds during projected extreme peak load conditions will be at least as high as the wind (about $22 \mathrm{mph}$ ) measured during the actual 1994-1995 winter peak conditions in this study, about half of nameplate $\mathrm{kW}$ capacity distribution facility deferral benefits will accrue to wind turbines.

Table 5.5 presents the benefit-cost results assuming a MW-scale wind farm is installed in 2000 . In this case the total combined benefits are $\$ 1,603 / \mathrm{kW}$ and the benefit-to-cost ratio is 1.63 , which shows that the wind farm is still a highly cost-effective alternative. Without EPACT 
benefits, the benefit-to-cost ratio drops to 1.48 and the MW-scale wind farm is still a highly costeffective alternative.

Table 5.5. Benefit-cost results-install MW-scale wind farm in 2000, measured $22 \mathrm{mph}$ annual peak wind speed

\begin{tabular}{lcc}
\hline & PWRR $\$^{\mathrm{a}}$ & $\$ / \mathrm{kW}$ \\
\hline \multicolumn{1}{c}{ Benefits } & & \\
Distribution Facility Deferral & 951,140 & 558 \\
Energy Charge Reduction & $1,322,837$ & 776 \\
Demand Charge Reduction & 140,018 & $\mathbf{8 2}$ \\
Distribution Losses & 64,694 & 38 \\
Energy Policy Act & 253,189 & 149 \\
Total Benefits & $\mathbf{2 , 7 3 1 , 8 7 8}$ & $\mathbf{1 , 6 0 3}$ \\
Total Cost & $\mathbf{1 , 6 7 4 , 5 2 2}$ & $\mathbf{9 8 3}$ \\
Benefit-to-cost ratio & $\mathbf{1 . 6 3}$ & \\
\hline
\end{tabular}

a Present worth of revenue requirements

Again adding a battery storage plant can enhance wind turbine performance. Table 5.6 presents the benefit-cost results assuming a MW-scale wind farm is installed in 2000 . In addition, a $500-\mathrm{kW}, 2$-hour battery plant is assumed to be leased for 2 years from 2002 through 2003. Leasing a $500-\mathrm{kW}$ battery storage plant again enhances the $\mathrm{MW}$-scale wind farm benefits more than the incremental increase in costs. In this case, the total combined benefits are $\$ 1,830 / \mathrm{kW}$ and the benefit-to-cost ratio is 1.71 . This shows that the wind farm plus leased battery plant may be a more cost-effective alternative than wind alone for other potential applications, if the wind farm can not attain full distribution benefits. Without EPACT benefits, the benefit-to-cost ratio drops to 1.57 , and the MW-scale wind farm plus leased $500-\mathrm{kW}$ battery plant is still a highly cost-effective alternative.

A $500-\mathrm{kW}$ battery storage plant could be purchased rather than leased, and provide enhanced wind farm benefits throughout the study period. The resulting combined benefits are $\$ 2,278 / \mathrm{kW}$, and the benefit-to-cost ratio is 1.65 , as shown in Table 5.7. Again this is a costeffective alternative. However, the benefit-to-cost ratio for leasing the battery storage plant for 2 years shown in Table 5.6 is significantly higher than purchasing the battery storage plant. Hence, in the general case, leasing a battery storage plant to enhance wind benefits also appears more economically attractive, unless other distribution deferral benefits can be identified and accrued over the battery plant life.

Comparing these results with the corresponding OPALCO benefit-cost results in Section 4.4 .2 , other potential applications of wind enhanced by battery storage with larger energy and demand charges can produce significantly higher benefit-cost ratios:

- 1.63 vs 1.15 for a MW-scale wind farm,

- $\quad 1.71$ vs 1.24 for a MW-scale wind farm and lease a $500-\mathrm{kW}$ battery; and

- 1.65 vs 1.12 for a MW-scale wind farm and purchase a $500-\mathrm{kW}$ battery. 
Table 5.6. Benefit-cost results-install a MW-scale wind farm in 2000 and lease a $500-\mathrm{kW}$ battery storage plant in 2002 , measured $22 \mathrm{mph}$ annual peak wind speed

\begin{tabular}{lcc}
\hline & PWRR $\$$ a & $\$ / \mathrm{kW}$ \\
\hline \multicolumn{1}{c}{ Benefits } & & \\
Distribution Facility Deferral & $1,278,633$ & 750 \\
Energy Charge Reduction & $1,324,555$ & 777 \\
Demand Charge Reduction & 204,438 & 120 \\
Distribution Losses & 56,914 & 33 \\
Energy Policy Act & 253,189 & 149 \\
$\quad$ Total Benefits & $\mathbf{3 , 1 1 7 , 7 2 8}$ & $\mathbf{1 , 8 3 0}$ \\
$\quad$ Total Cost & $\mathbf{1 , 8 2 2 , 3 8 1}$ & $\mathbf{1 , 0 7 0}$ \\
Benefit-to-cost ratio & $\mathbf{1 . 7 1}$ & \\
\hline
\end{tabular}

${ }^{\text {a }}$ Present worth of revenue requirements

Table 5.7. Benefit-cost results-install a $\mathbf{M W}$-scale wind farm in 2000 and purchase a $500-\mathrm{kW}$ battery storage plant in 2002 , measured $22 \mathrm{mph}$ annual peak wind speed

\begin{tabular}{|c|c|c|}
\hline & PWRR $\$$ & $\$ / \mathrm{kW}$ \\
\hline \multicolumn{3}{|l|}{ Benefits } \\
\hline Distribution Facility Deferral & $1,462,526$ & 858 \\
\hline Energy Charge Reduction & $1,338,985$ & 786 \\
\hline Demand Charge Reduction & 745,593 & 438 \\
\hline Distribution Losses & 80,474 & 47 \\
\hline Energy Policy Act & 253,189 & 149 \\
\hline Total Benefits & $3,880,767$ & 2,278 \\
\hline Total Cost & $2,346,863$ & 1,377 \\
\hline Benefit-to-cost ratio & 1.65 & \\
\hline
\end{tabular}

\subsubsection{Battery Storage Only}

Battery storage can also be strategically added on a distribution circuit without the wind farm, and defer circuit upgrades. A transportable 500-kW, 2-hour battery storage plant could be leased for 2 years from 2000 through 2001 . During the 2 year lease period, the battery plant can defer distribution facility upgrades and reduce utility monthly demand charges. Again there is a 
relatively small reduction in energy charges. In this case, the total combined benefits are $\$ 795 / \mathrm{kW}$ and the benefit-to-cost ratio is 4.02 , as shown in Table 5.8. Most of the benefits are based on deferring the distribution circuit upgrade, but demand charge reduction benefits are also significant. Again the large benefit-to-cost ratio results from the relatively low lease costs over the 2 year period.

If the battery storage plant is purchased in 2000 rather than leased, the resulting total combined benefits are $\$ 1,972 / \mathrm{kW}$ and the benefit-to-cost ratio is 2.11 , as shown in Table 5.9. In this case, the planned distribution circuit upgrades in 2000, 2006, and 2008 are deferred, and monthly demand charges are reduced throughout the study period.

Table 5.8. Benefit-cost results-lease a $500-\mathrm{kW}$ battery storage plant in 2000 for 2 years

\begin{tabular}{lcc}
\hline & PWRR \$ & \$/kW \\
\hline Benefits & & \\
Distribution Facility Deferral & 567,669 & 700 \\
Energy Charge Reduction & 2,017 & 2 \\
Demand Charge Reduction & 75,655 & 93 \\
Total Benefits & $\mathbf{6 4 5 , 3 4 1}$ & $\mathbf{7 9 5}$ \\
Total Cost & $\mathbf{1 6 0 , 5 4 5}$ & $\mathbf{1 9 8}$ \\
Benefit-to-cost ratio & $\mathbf{4 . 0 2}$ & \\
\hline a present worth of revenue requirements & &
\end{tabular}

Table 5.9. Benefit-cost results-purchase a 500-kW battery storage plant in 2000

\begin{tabular}{lcc}
\hline & PWRR $^{\mathbf{a}}$ & \$/kW \\
\hline \multicolumn{1}{c}{ Benefits } & & \\
Distribution Facility Deferral & 951,140 & 1,172 \\
Energy Charge Reduction & 16,149 & 20 \\
Demand Charge Reduction & 605,576 & 746 \\
Distribution Losses & 26,781 & 33 \\
Total Benefits & $\mathbf{1 , 5 9 9 , 6 4 6}$ & $\mathbf{1 , 9 7 2}$ \\
Total Cost & $\mathbf{7 5 7 , 3 3 7}$ & $\mathbf{9 3 3}$ \\
Benefit-to-cost ratio & $\mathbf{2 . 1 1}$ & \\
\hline a present worth of revenue requirements & &
\end{tabular}

Comparing these results with the corresponding OPALCO benefit-cost results in Section 4.4.3, other potential applications of battery storage with larger energy and demand charges can produce significantly higher benefit-cost ratios:

- 4.02 vs 3.68 when leasing a $500-\mathrm{kW}$ battery; and

- 2.11 vs 1.52 when purchasing a $500-\mathrm{kW}$ battery. 


\subsection{RESULTS AND CONCLUSIONS}

\subsection{SUMMARY OF RESULTS}

\subsubsection{OPALCO Application Results}

Expected benefits to OPALCO associated with adding a MW-scale wind farm and battery storage are:

- defer planned Lopez-Eastsound circuit upgrade to $69 \mathrm{kV}$,

- energy charge reduction,

- monthly demand charge reduction,

- reduction in distribution losses; and

- Energy Policy Act (EPACT) production incentive.

Deferral of the Lopez-Eastsound distribution circuit upgrades, energy displacement, and monthly demand charge reduction are the most important benefits. Potential reduction in distribution losses are small because upgrading to $69 \mathrm{kV}$ also reduces losses. The EPACT production incentive benefit is law, and hopefully will be funded by the year 2000 . However, there is currently no mechanism for the Federal government to fund this incentive for publicly owned utilities.

Wind data collection results indicate that Mt. Constitution is a good wind site. Assuming the measured winds at the instrument height of $163^{\prime}$, the resulting annual capacity factor for a wind farm installed at this location is $21.2 \%$. Measured wind data indicated good correlation between high winds and projected annual Eastsound peak load. A wind speed of approximately $22 \mathrm{mph}$ was measured during the actual annual 1994-1995 winter Eastsound peak load during this mild winter. It is very likely that winds of at least $22 \mathrm{mph}$ will be experienced during projected extreme winter peak load conditions.

If the wind can be counted on to exceed $26 \mathrm{mph}$ during projected extreme annual Eastsound peak loads, distribution facility deferral benefits totaling full nameplate $\mathrm{kW}$ capacity will accrue to a MW-scale wind farm consisting of up to $3-350 \mathrm{~kW}$ variable speed wind turbines installed on Mt. Constitution in 2000 . Adding 1-350 kW wind turbine defers the planned Lopez-Eastsound circuit upgrade to $69 \mathrm{kV}$ for 2 years resulting in total economic benefits of $\$ 1,928 / \mathrm{kW}$ and a benefit-to-cost ratio of 1.96 . Adding $2-350 \mathrm{~kW}$ wind turbines defers the planned circuit upgrade for 3 years resulting in total economic benefits of $\$ 1,570 / \mathrm{kW}$ and a benefit-to-cost ratio of 1.60 . Adding three $3-350 \mathrm{~kW}$ wind turbines defers the planned upgrade for 4 years resulting in total benefits of $\$ 1,443 / \mathrm{kW}$ and a benefit-to-cost ratio of 1.47 .

If the wind can be counted on to equal or exceed the measured $22 \mathrm{mph}$ during projected extreme annual Eastsound peak loads, distribution deferral benefits of approximately half the nameplate $\mathrm{kW}$ capacity will accrue to a MW-scale wind farm installed on Mt. Constitution in 2000 . In this case, adding $3-350 \mathrm{~kW}$ wind turbines defers the planned circuit upgrade to $69 \mathrm{kV}$ for 2 years, resulting in total economic benefits of $\$ 1,129 / \mathrm{kW}$ and a benefit-to-cost ratio of 1.15 .

Assuming the above $22 \mathrm{mph}$ wind case, adding a $500-\mathrm{kW}$, 2-hour battery storage plant near Eastsound will enhance the MW-scale wind farm performance, and increase benefits to OPALCO. Adding the battery storage plant will provide full $1,050-\mathrm{kW}$ Eastsound peak load reduction capability. OPALCO can also operate the battery to reduce monthly demand charges throughout the year. In addition the battery storage can back up the wind farm during 
unexpected low wind conditions. Leasing the battery storage plant for 2 years increases the MW-scale wind farm benefits to $\$ 1,330 / \mathrm{kW}$ and the benefit-to-cost ratio to 1.24 .

If potential EPACT benefits are not included, the above total benefits associated with adding a wind farm will be reduced about $\$ 150 / \mathrm{kW}$.

\subsubsection{Extrapolation to Other Potential Applications}

It is expected that the similar benefits from adding a MW-scale wind farm and battery storage in this study will also apply to many other winter peaking utilities throughout the northern United States. Distribution circuit upgrades are based on extreme annual winter peak design loads which occur during coincident low temperature and high wind ambient conditions for many other winter peaking utilities. For many of these utilities in different regions of the United States, demand and energy charges are expected to be significantly higher than OPALCO's costs, as shown in the previous study.$^{1-2}$ Assuming these representative higher demand and energy charges, significantly larger benefits are expected to accrue to MW-scale wind farms and battery storage, as presented in Section 5 .

If the wind can be counted on to exceed $26 \mathrm{mph}$ during extreme annual peak loads, the following increased benefits are likely in other potential applications. Adding 1-350 kW wind turbine results in total economic benefits of $\$ 2,416 / \mathrm{kW}$ vs $\$ 1,928 / \mathrm{kW}$ and a benefit-to-cost ratio of $2.46 \mathrm{vs} 1.96$. Adding $2-350 \mathrm{~kW}$ wind turbines results in total economic benefits of $\$ 2,058 / \mathrm{kW}$ vs $\$ 1,570 / \mathrm{kW}$ and a benefit-to-cost ratio of 2.09 vs 1.60 . Adding $3-350 \mathrm{~kW}$ wind turbines results in total economic benefits of $\$ 1,929 / \mathrm{kW}$ vs $\$ 1,443 / \mathrm{kW}$ and a benefit-to-cost ratio of $1.96 \mathrm{vs}$ 1.47 .

If the wind can be counted on to exceed $22 \mathrm{mph}$ during projected extreme annual peak loads, adding $3-350 \mathrm{~kW}$ wind turbines results in total economic benefits of $\$ 1,603 / \mathrm{kW}$ vs $\$ 1,129 / \mathrm{kW}$ and a benefit-to-cost ratio of 1.63 vs 1.15 . Again, leasing a $500-\mathrm{kW}, 2$-hour battery storage plant significantly enhances the wind farm benefits. In this case, leasing the battery plant increases the wind farm benefits to $\$ 1,830 / \mathrm{kW}$ and the benefit-to-cost ratio to 1.71 .

Again, if potential EPACT benefits are not included, the above total benefits associated with adding a wind farm will be reduced about $\$ 150 / \mathrm{kW}$, as this is independent of demand and energy costs.

If a transportable $500-\mathrm{kW}, 2$-hour battery storage plant is leased in 2000 for 2 years, the resulting total benefits are $\$ 795 / \mathrm{kW}$ vs $\$ 727 / \mathrm{kW}$ and the benefit-to-cost ratio is 4.02 vs 3.68 . If the battery plant is purchased in 2000 , total benefits are $\$ 1,972 / \mathrm{kW}$ vs $\$ 1,418 / \mathrm{kW}$ and the benefit-to-cost ratio is 2.11 vs 1.52 .

\subsection{CONCLUSIONS AND RECOMMENDATIONS}

The following conclusions and recommendations apply to the application of wind farms and battery storage near Eastsound:

- The measured wind data in this project indicate that Mt. Constitution is a good wind site, and that the OPALCO office site is a poor wind site.

- Adding a MW-scale wind farm at Mt. Constitution is an economic alternative to upgrading the Lopez-Eastsound circuit to $69 \mathrm{kV}$ in 2000. 
- Adding a battery storage plant in conjunction with the wind farm will enhance wind farm performance and increase the economic viability of the wind farm.

- Leasing a $500-\mathrm{kW}, 2$-hour battery storage plant in 2000 for 2 years without the wind farm is also an economic alternative to upgrading the Lopez-Eastsound circuit to $69 \mathrm{kV}$ in 2000.

- It is recommended that detailed wind measurements over the 1995-1996 winter be continued at the Mt. Constitution site to establish wind speeds during projected extreme peak load conditions.

- It is recommended that OPALCO develop functional specifications and obtain detailed cost estimates for wind turbines, and expected lease costs for transportable battery storage from potential vendors.

The following general conclusions and recommendations apply to potential applications of wind farms and battery storage to other winter peaking utility systems:

- Adding a MW-scale wind farm is expected to be an economic alternative to upgrading distribution facilities at many winter peaking utilities throughout the northern United States.

- Strategically adding battery storage in conjunction with a wind farm will significantly enhance wind farm benefits at locations where full wind farm MW capacity can not be counted on during extreme winter peak design loading conditions.

- The magnitude of wind farm and battery storage economic benefits is expected to vary significantly on both a site-specific and utility-specific basis, based on wind characteristics, utility distribution design characteristics, and cost variations.

- Extremely high winds and extremely high utility costs appear unnecessary to economically justify the addition of MW-scale wind farms and battery storage on many winter peaking utility systems in the northern United States. Instead, good wind sites coupled with normal utility costs are expected to result in numerous cases of economic viability.

- It is recommended that other potential applications of MW-scale wind farms and battery storage for other winter peaking utility systems in the northern United States be identified, and the economic viability investigated on a site-specific basis similar to this study. 


\section{REFERENCES}

1. Oak Ridge National Laboratory, The Integration of Renewable Energy Sources into Electric Power Distribution Systems, Vol. I National Assessment, ORNL-6775/V1, June 1994.

2. Oak Ridge National Laboratory, The Integration of Renewable Energy Sources into Electric Power Distribution Systems, Vol. II Utility Case Assessments, ORNL-6775/V2, June 1994.

3. U.S. House of Representatives, Conference Report: Energy Policy Act of 1992 to Accompany H.R. 776, U.S. Government Printing Office, Washington, D.C., October 5, 1992. 


\section{APPENDIX A \\ HOURLY EASTSOUND LOADS FROM MARCH 1994 THROUGH FEBRUARY 1995}

Eastsound is served from Cable Number 3, where circuit integrated hourly loads are metered. Conversations with Orcas Power and Light personnel indicated that the Eastsound portion of the total hourly cable load was approximately $40 \%$ of the total Cable 3 load from March 1, 1994 through May 5, 1994; 60\% from May 6, 1994 through November 30, 1994; and 43\% from December 1, 1994 through February 28, 1995.

Figures A.1 through A.12 present the resulting hourly Eastsound loads monthly from March 1994 through February 1995 respectively. In Figure A.5, there were questionable meter readings on July 28, which indicated large Eastsound loads. These large questionable loads were ignored when calculating peak demand reduction for July. In October (Figure A.8) temporary load switching on Cable 3 occurred during the middle of the month, and the resulting metering did not reflect the actual Eastsound load. Hence, these data are not included in this study. 


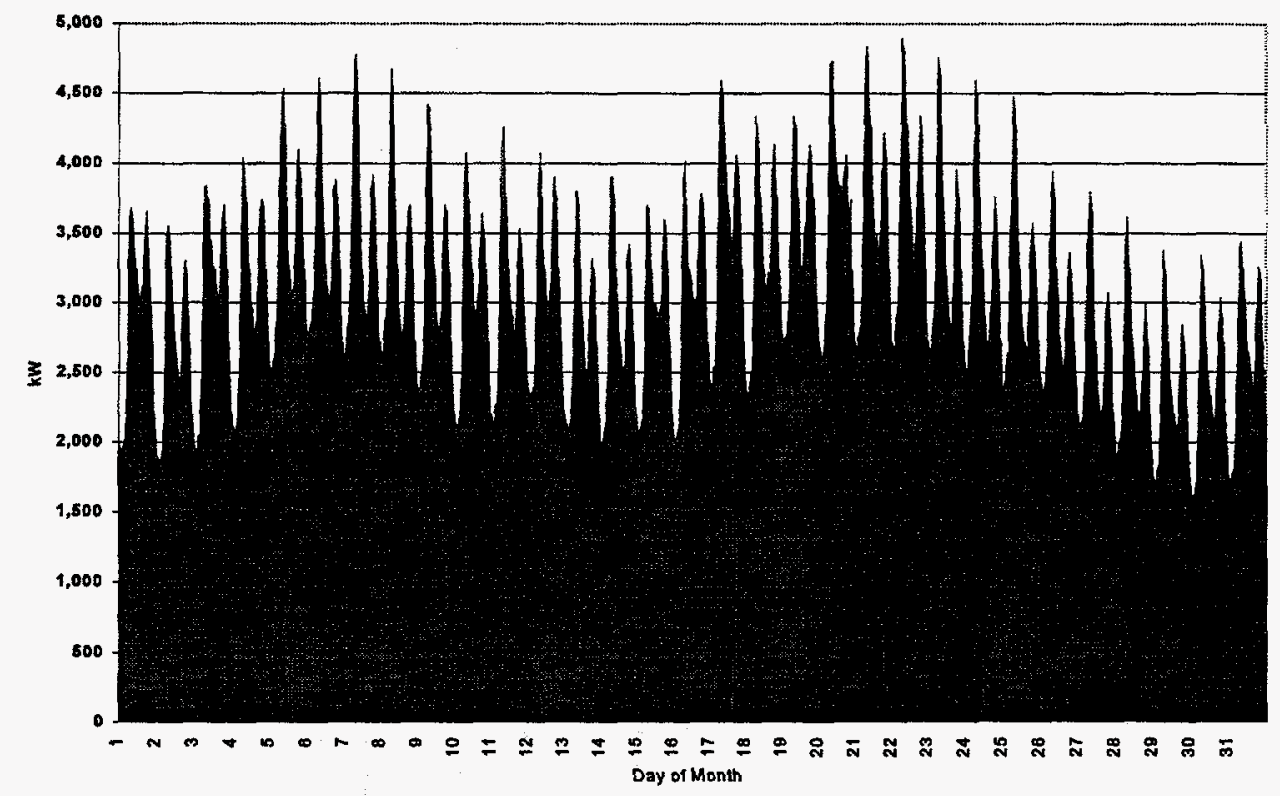

Fig. A.1. Hourly Eastsound load-March 1994.

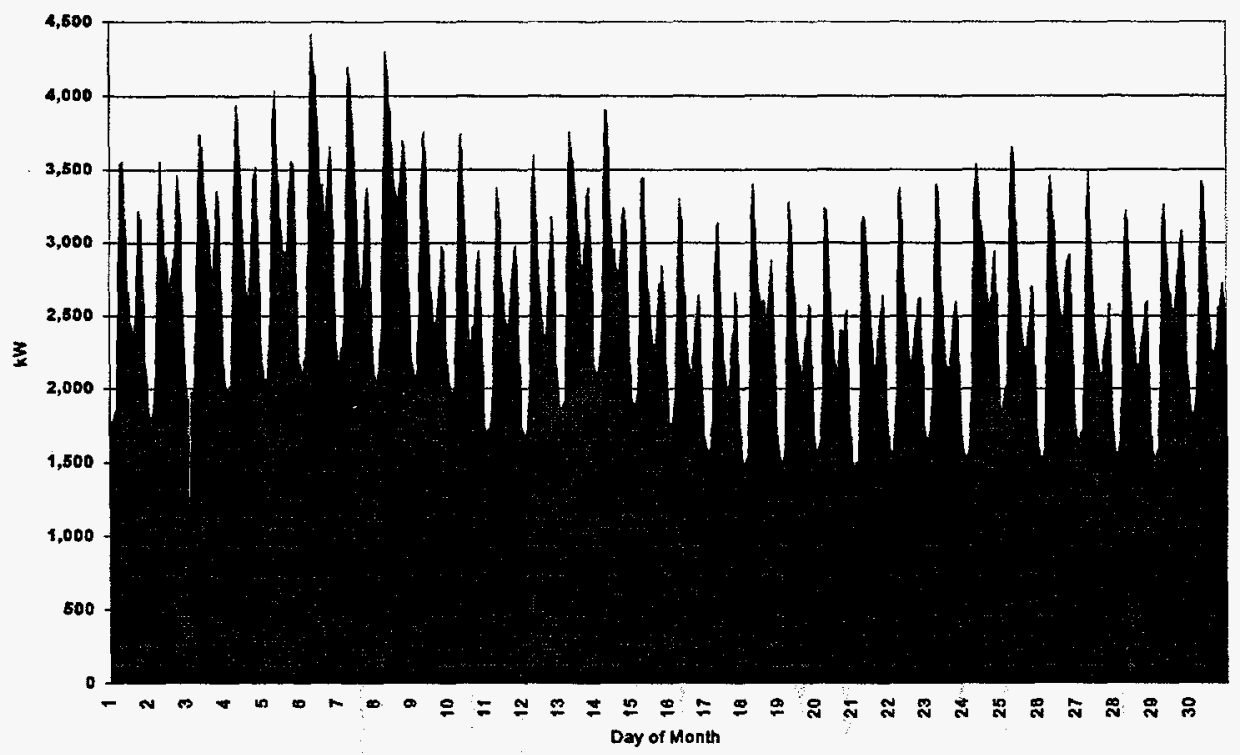

Fig. A.2. Hourly Eastsound load-April 1994. 


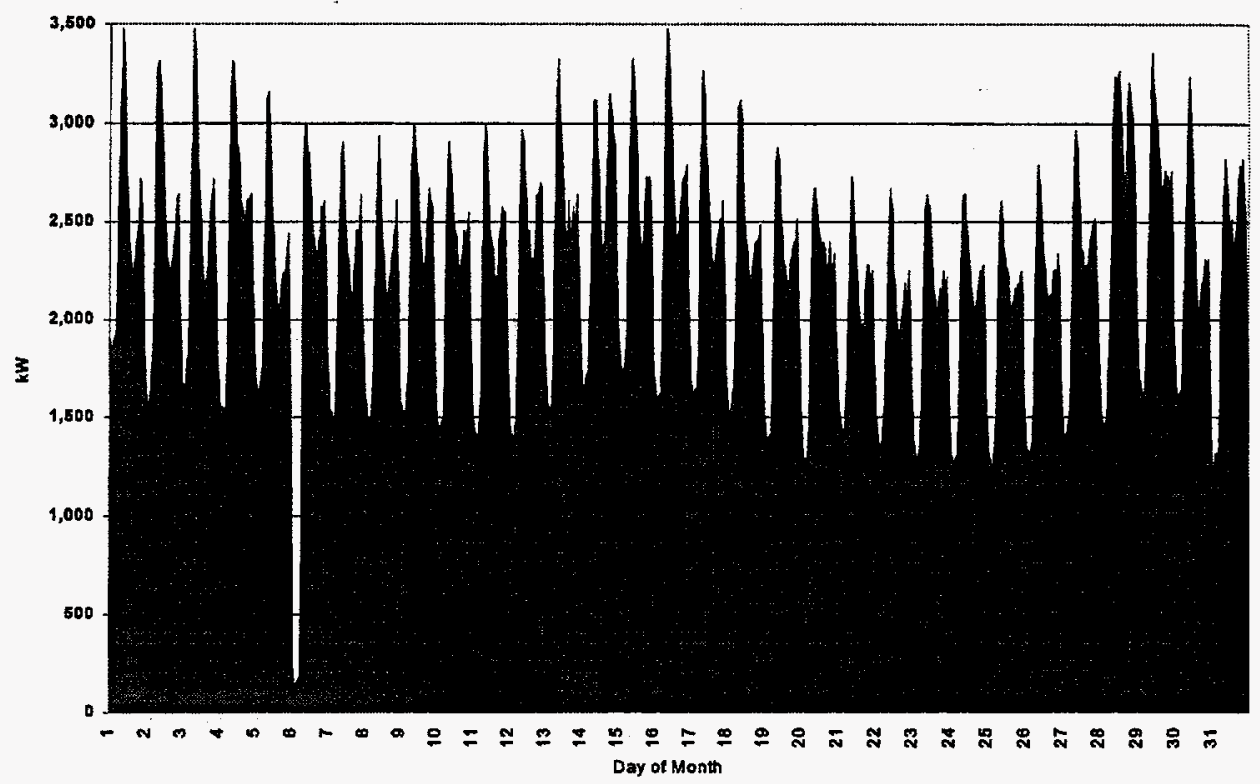

Fig. A.3. Hourly Eastsound load-May 1994.

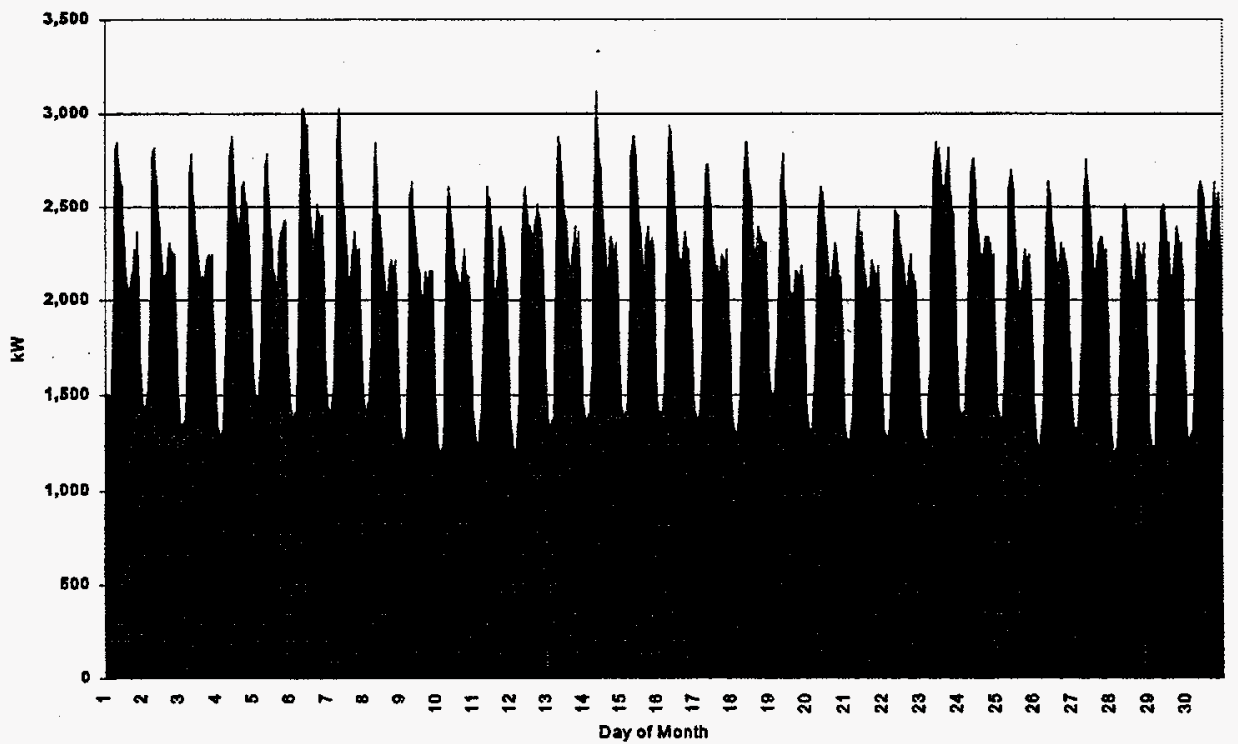

Fig. A.4. Hourly Eastsound load-June 1994. 


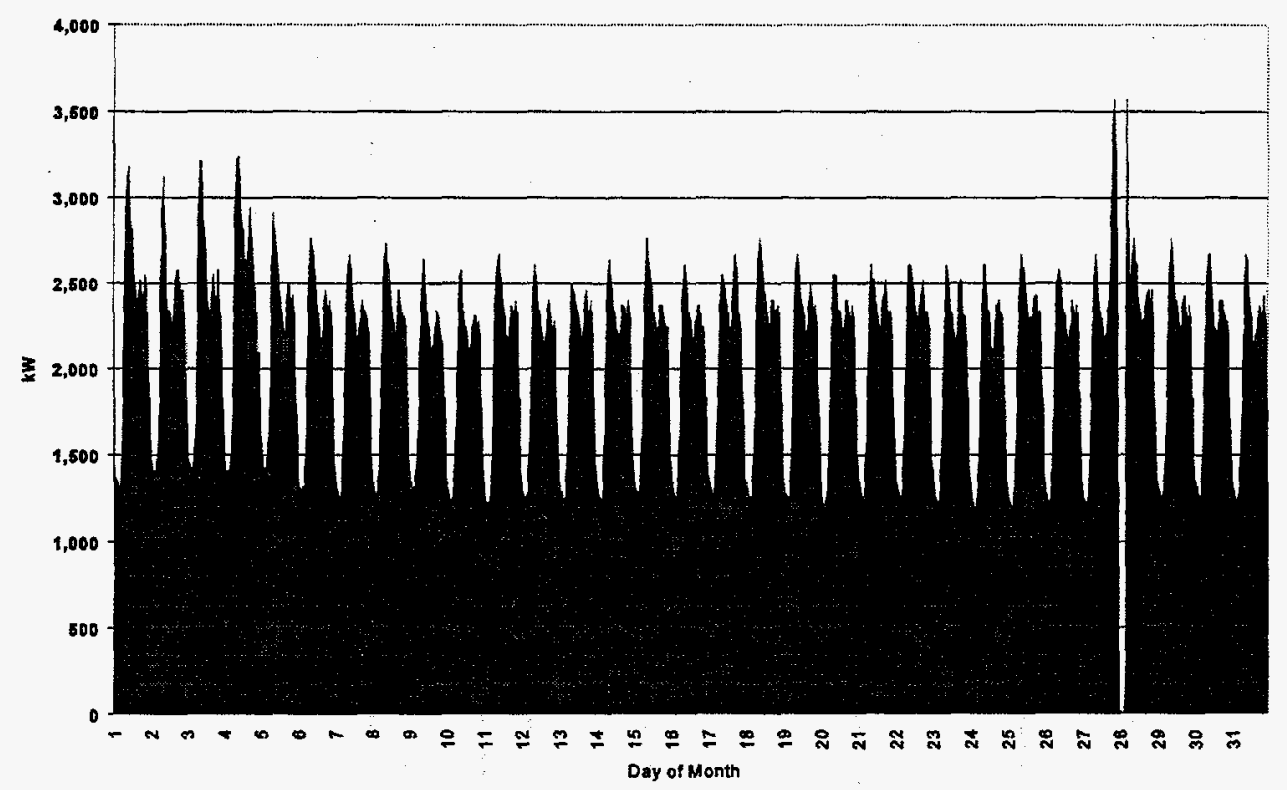

Fig. A.5. Hourly Eastsound load-July 1994.

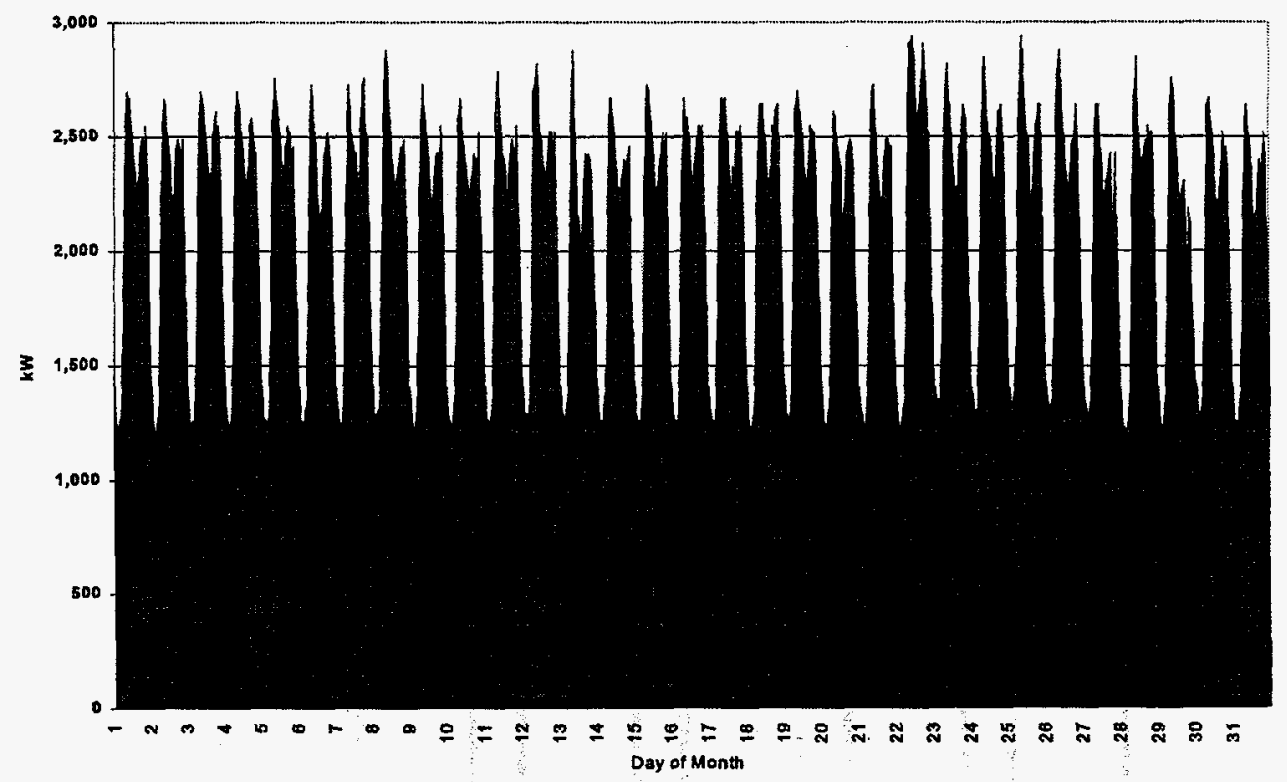

Fig. A.6. Hourly Eastsound load-August 1994. 


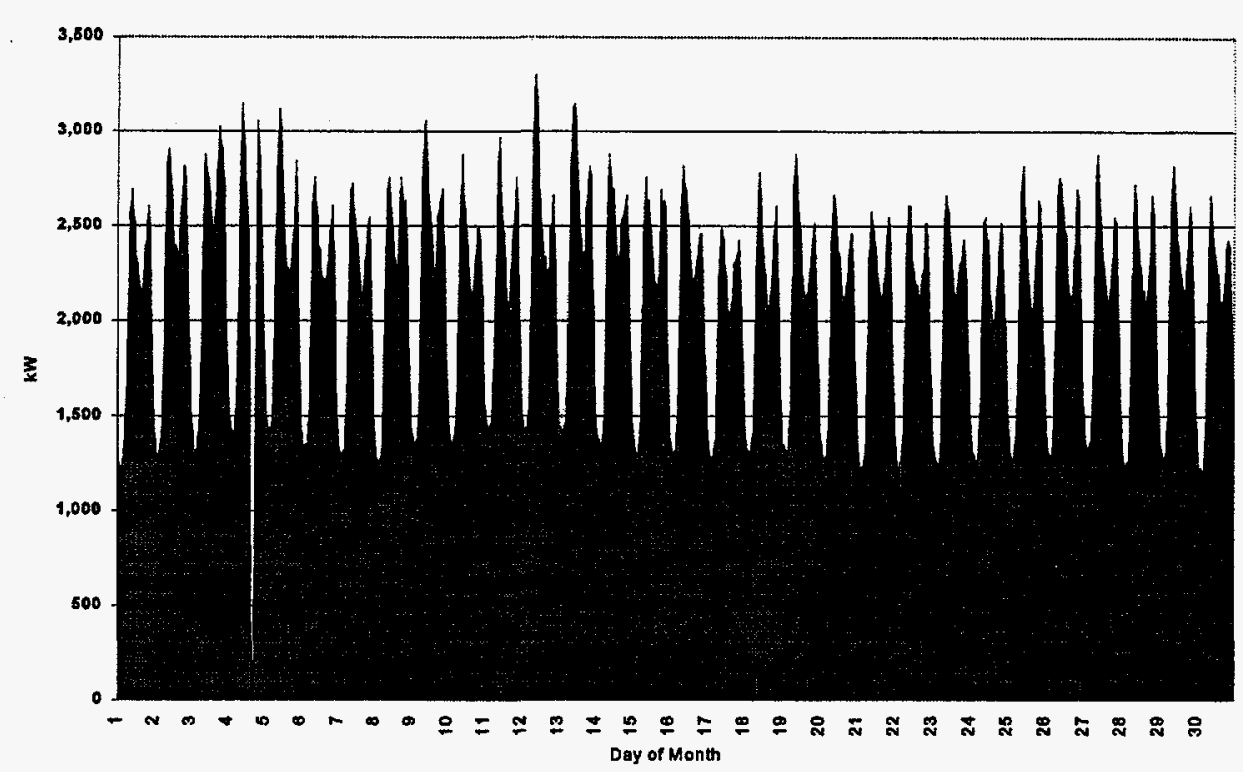

Fig. A.7. Hourly Eastsound load-September 1994.

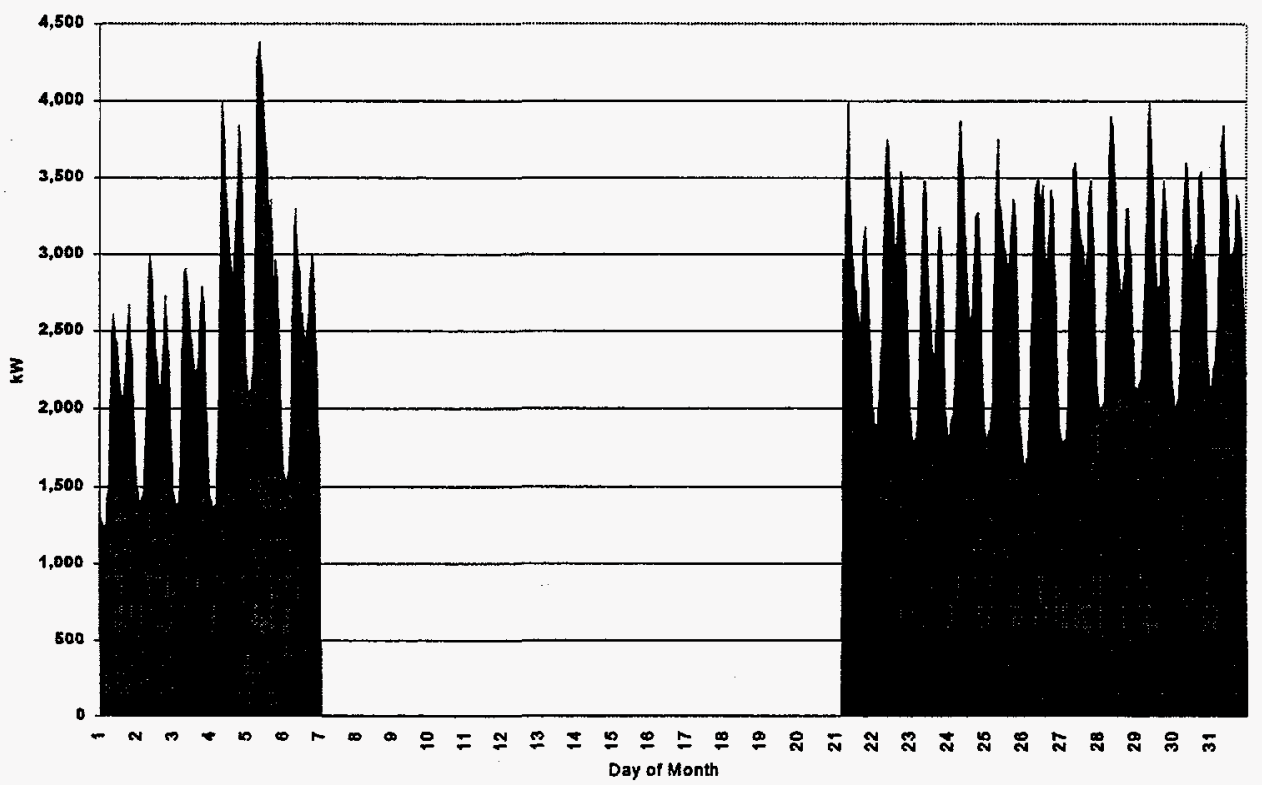

Fig. A.8. Hourly Eastsound load-October 1994. 


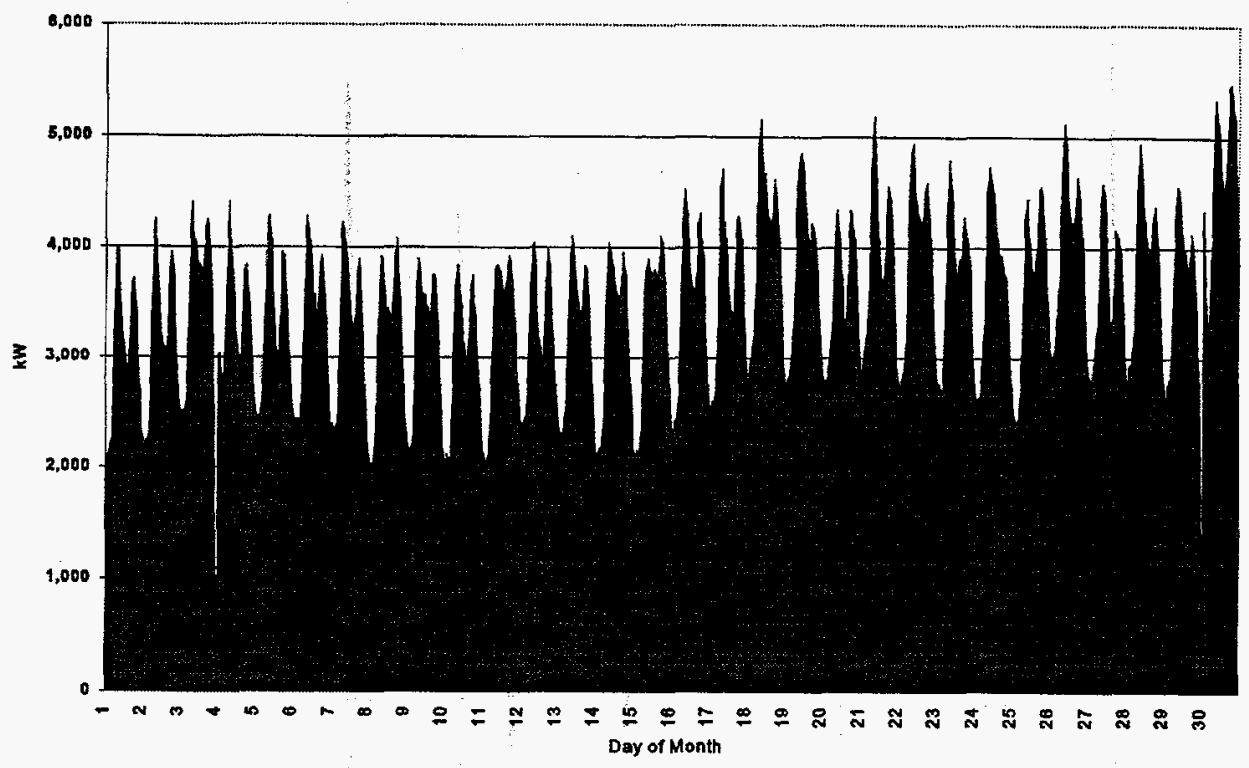

Fig. A.9. Hourly Eastsound load-November 1994.

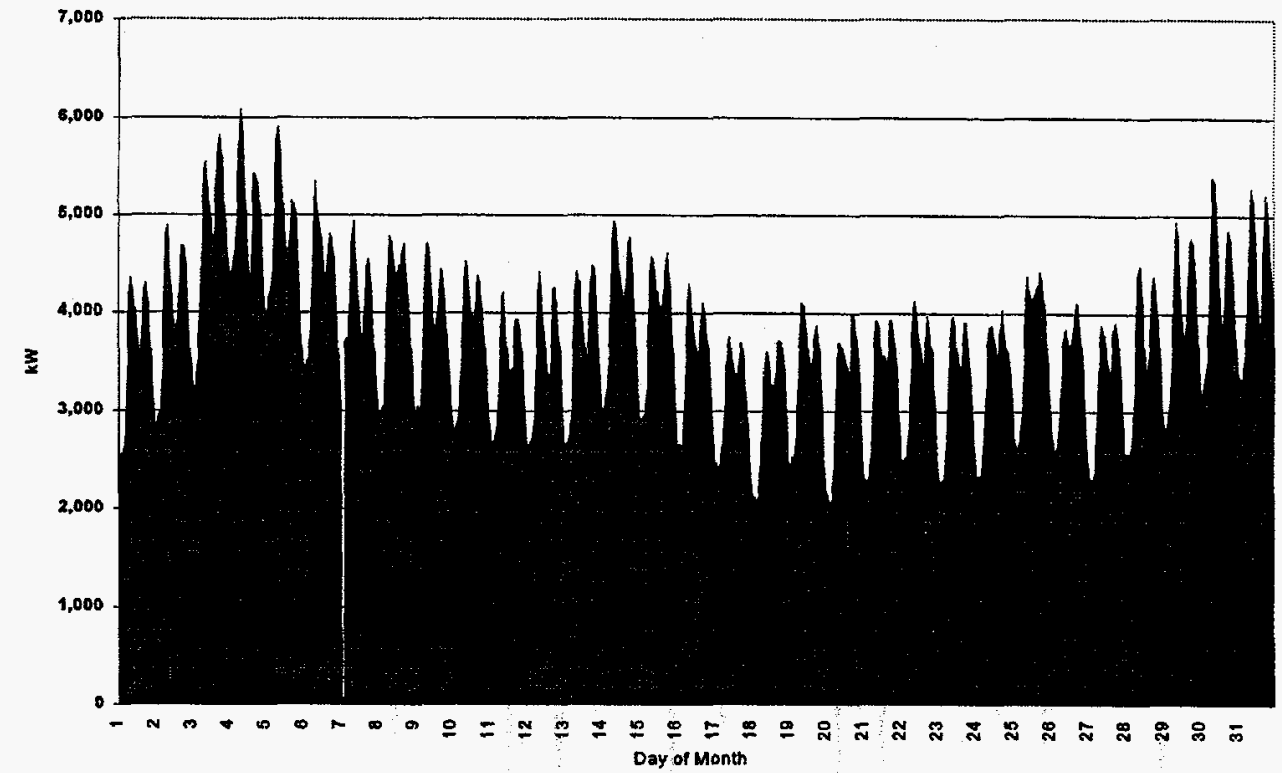

Fig. A.10. Hourly Eastsound load-December 1994. 


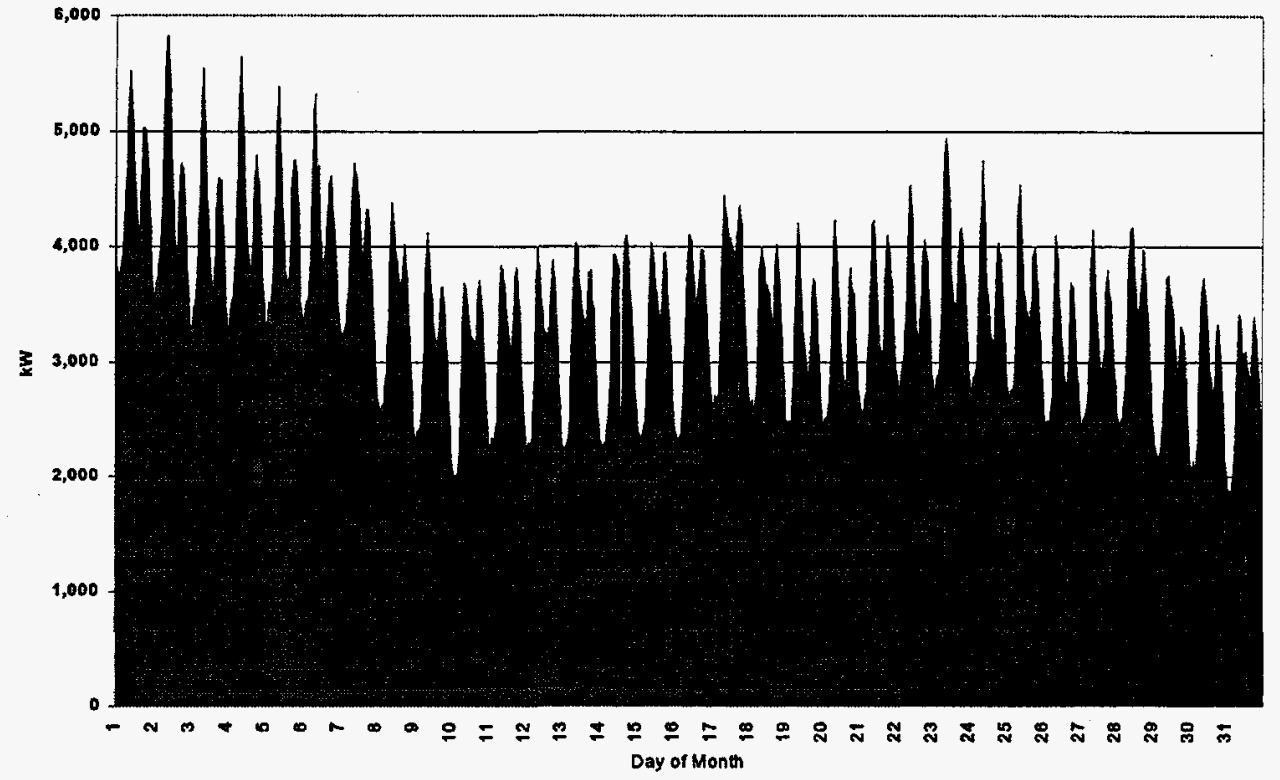

Fig. A.11. Hourly Eastsound load-January 1995.

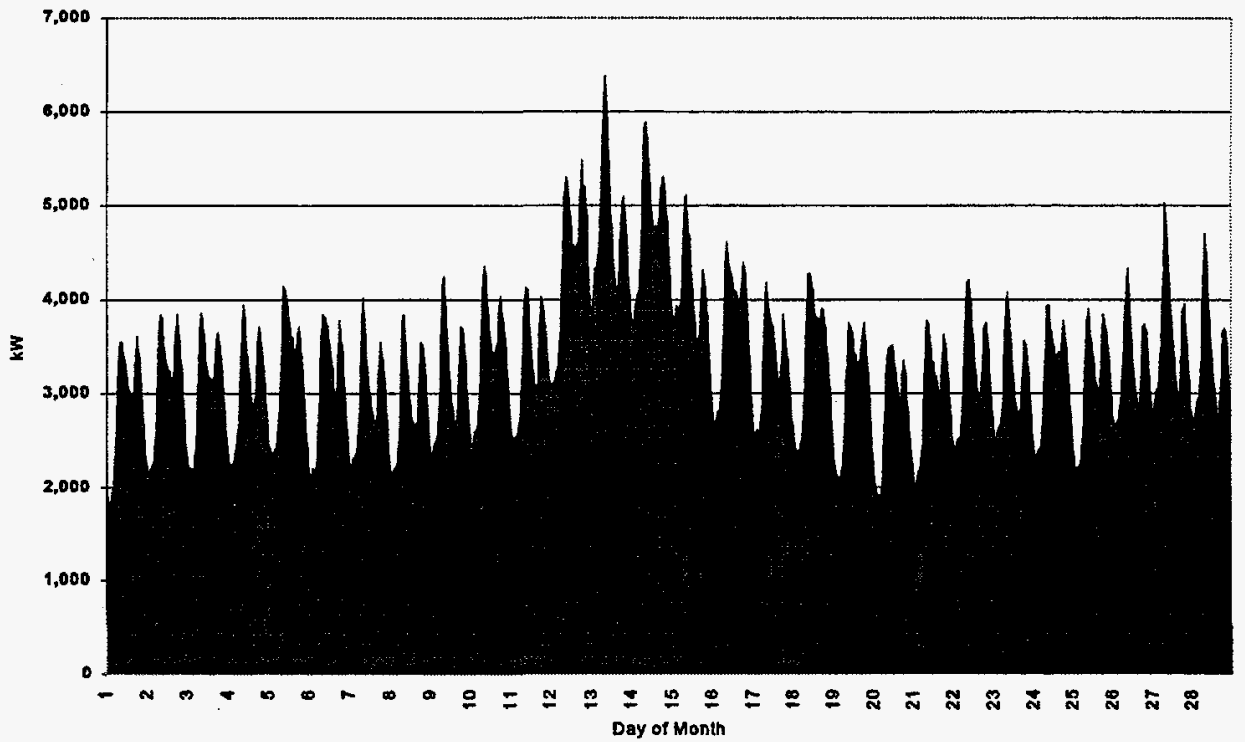

Fig. A.12. Hourly Eastsound load-February 1995. 


\section{APPENDIX B}

\section{HOURLY WIND AND MW-SCALE WIND PLANT PERFORMANCE- MT. CONSTITUTION 163'}

Hourly wind data were collected near the top of Mt. Constitution at $163^{\prime}$ and at $120^{\prime}$ above the ground. Figures B.1 through B.12 present the hourly winds monthly from March 1994 through February 1995 at the 163' level. Wind data for August 1994 were lost. For this study, hourly wind data for July 1994 (Figure B.5) were also assumed for August 1994 (Figure B.6).

Resulting hourly MW-scale wind plant performance are presented in Figures B.13 through B.24 for March 1994 through February 1995 assuming the above wind data, three 350 $\mathrm{kW}$ variable speed wind turbines, and the wind-power curve presented in Figure 3.1.

Figures B.25 through B.36 illustrate the resulting hourly correlation of a MW-scale wind plant output with the hourly Eastsound loads from March 1994 through February 1995. 


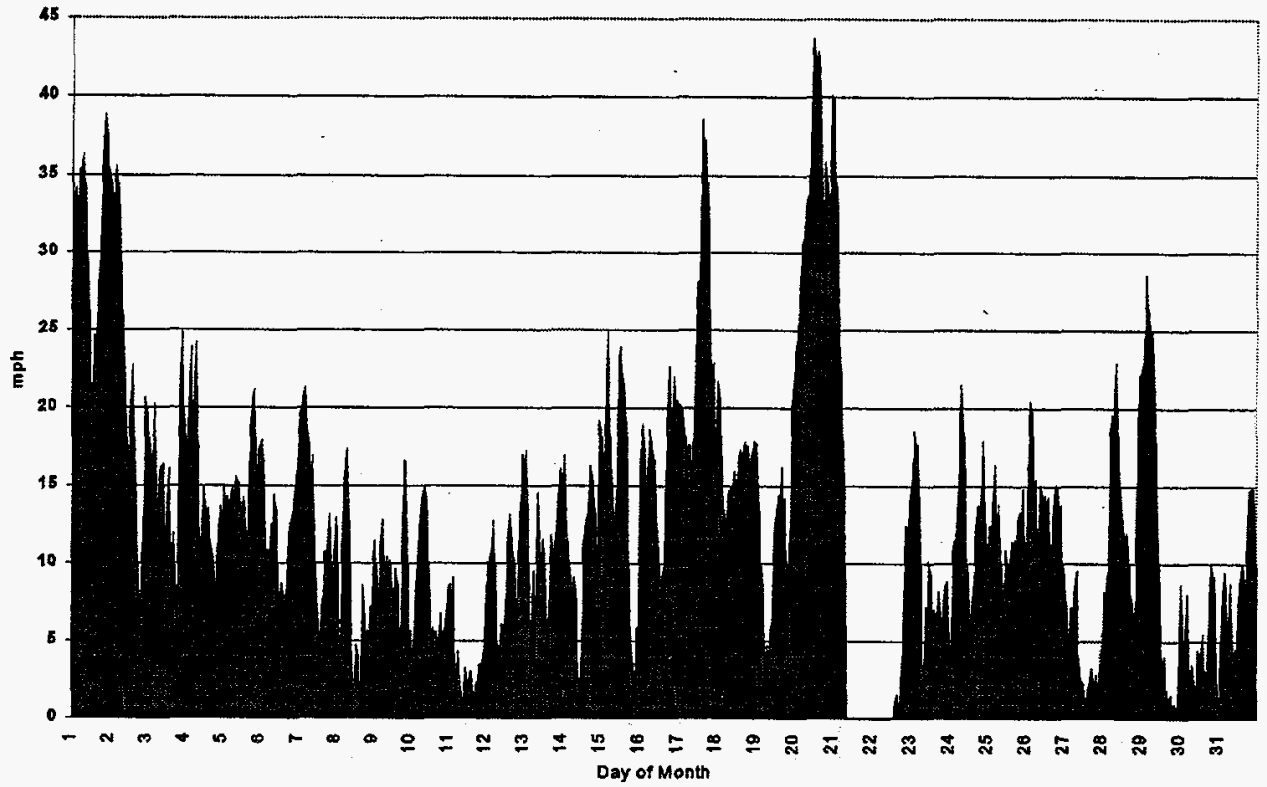

Fig. B.1. Hourly Mt. Constitution wind speed at 163'-March 1994.

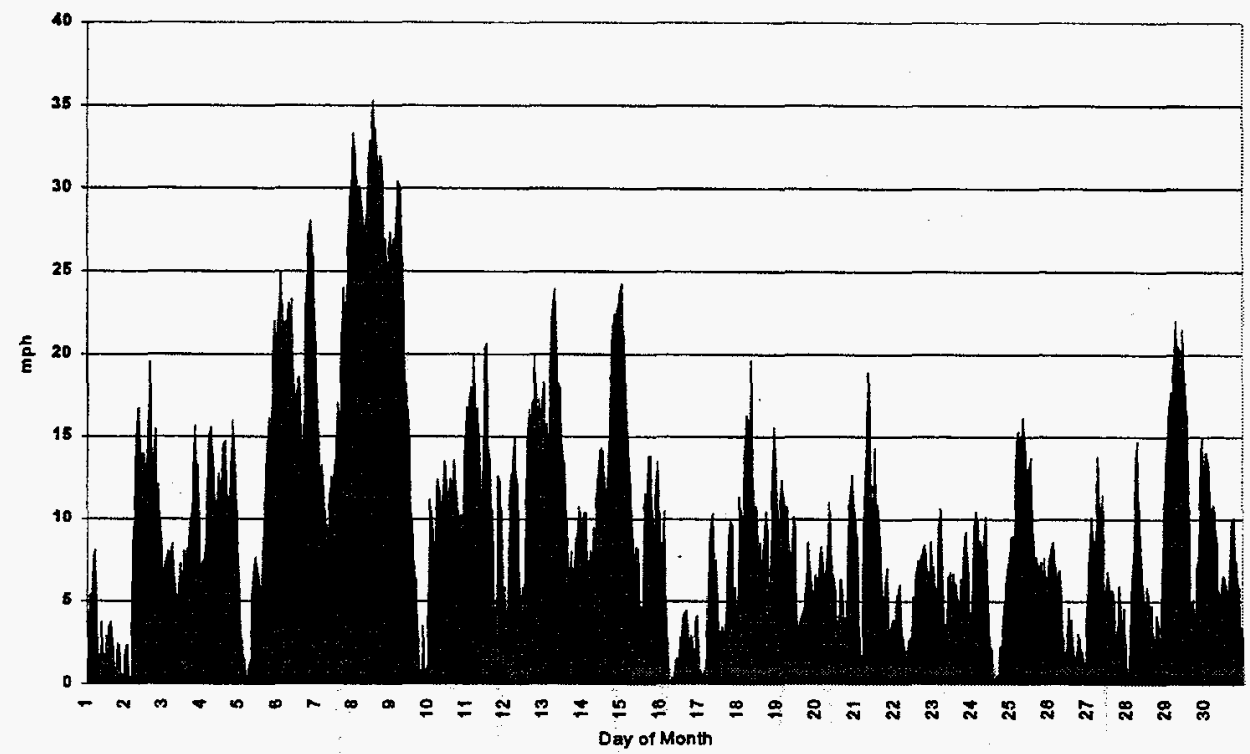

Fig. B.2. Hourly Mt. Constitution wind speed at 163'-April 1994. 


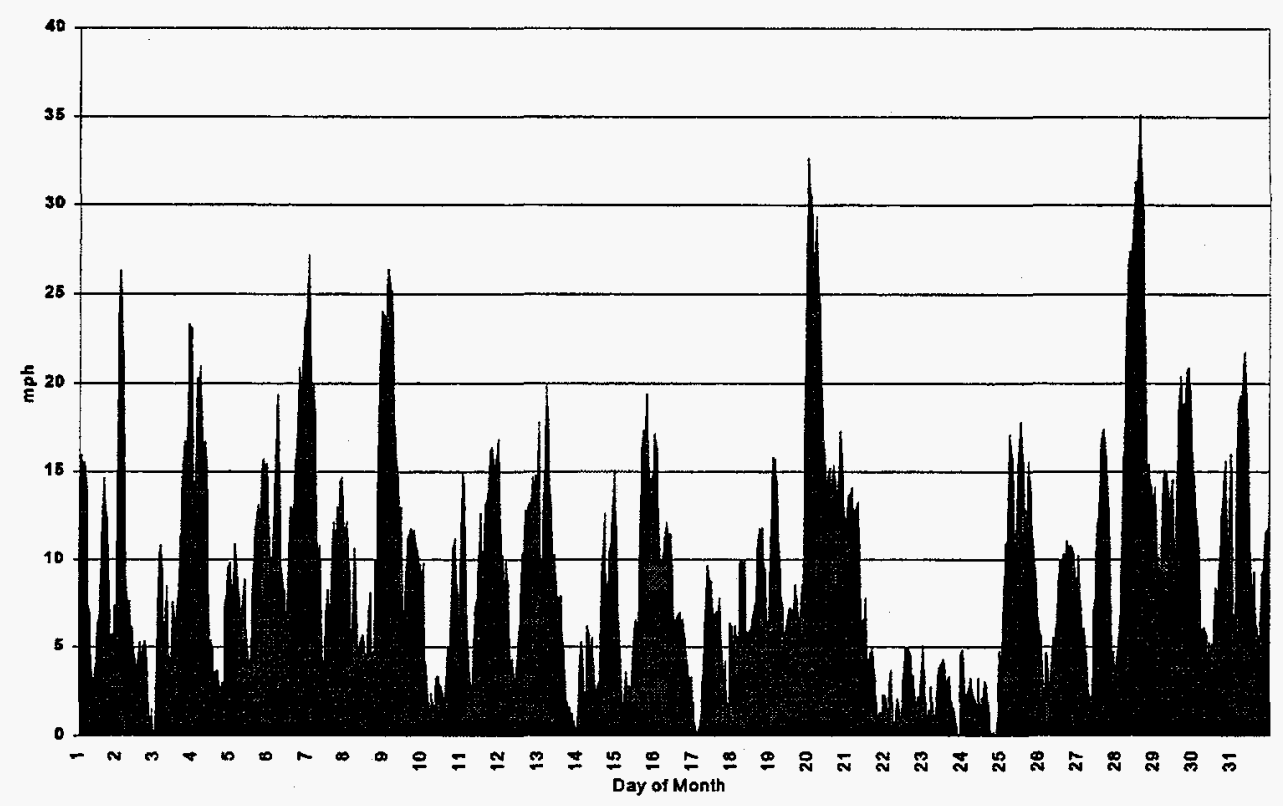

Fig. B.3. Hourly Mt. Constitution wind speed at 163'-May 1994.

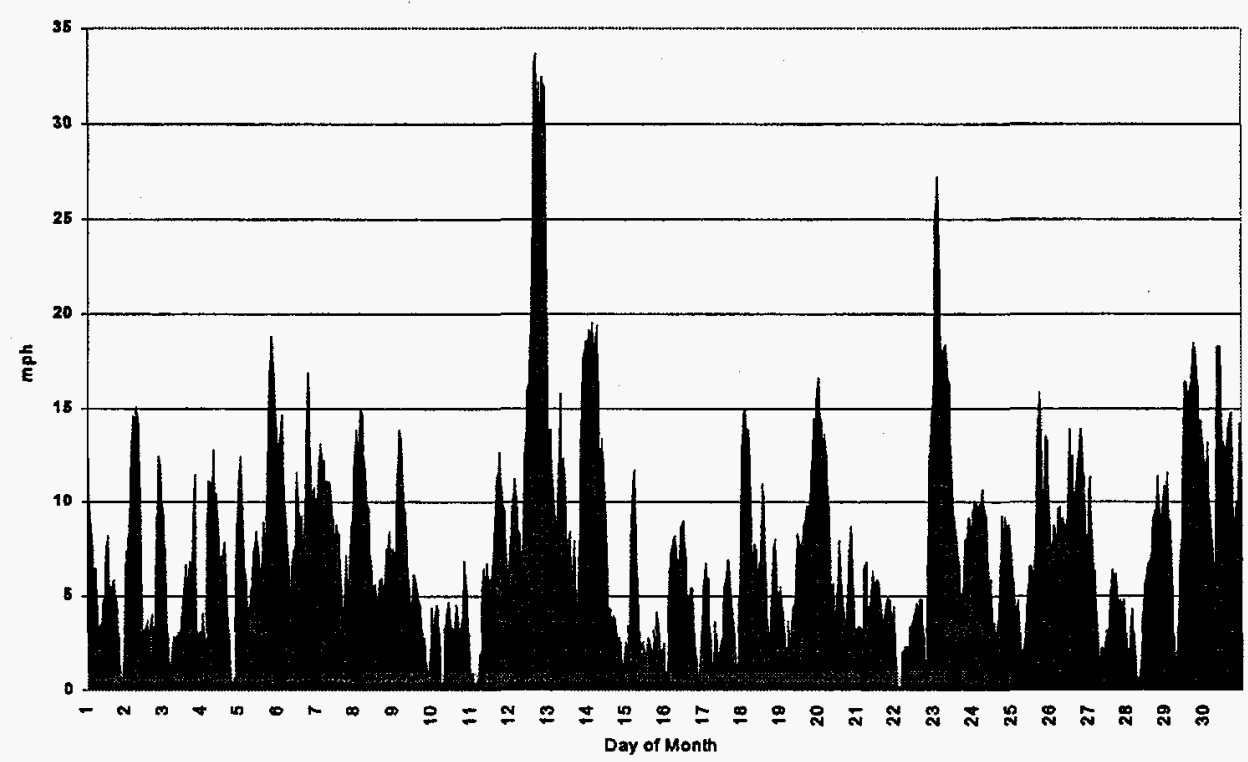

Fig. B.4. Hourly Mt. Constitution wind speed at 163'-June 1994. 


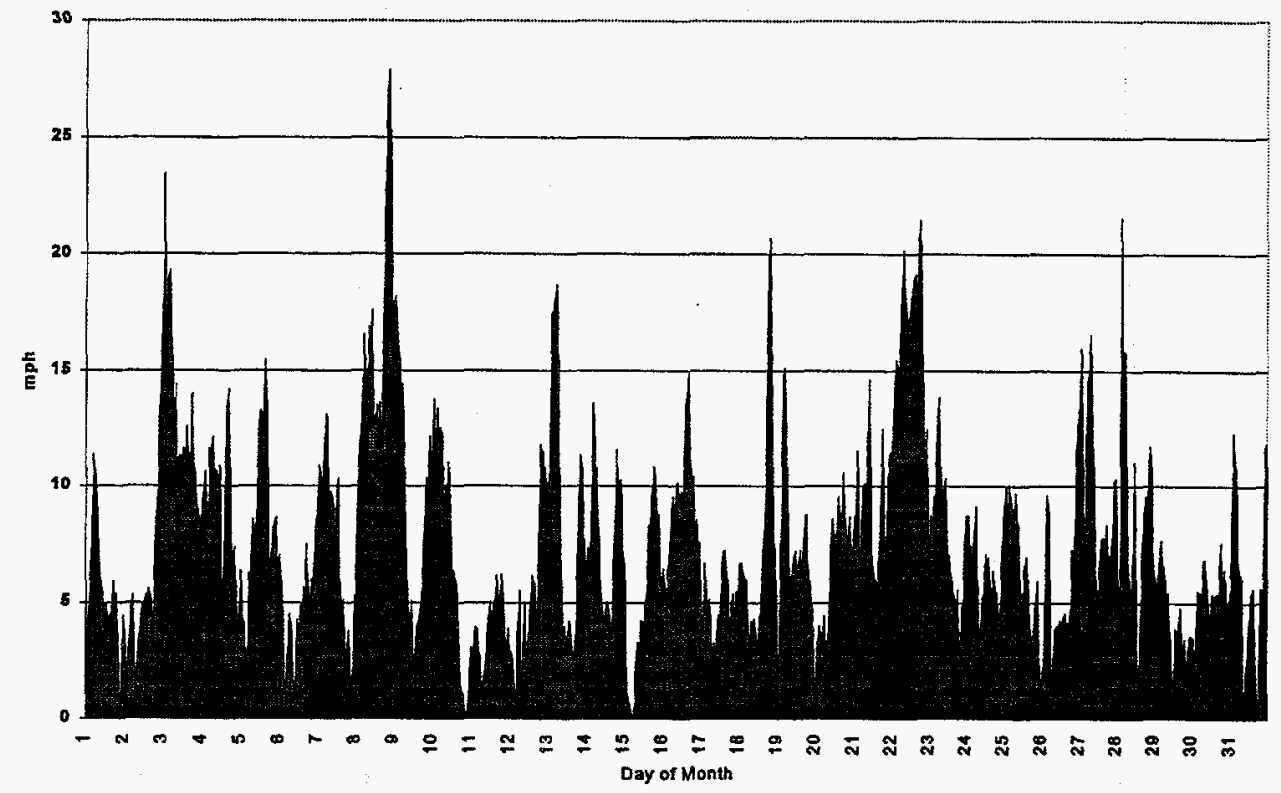

Fig. B.5. Hourly Mt. Constitution wind speed at 163'-July 1994.

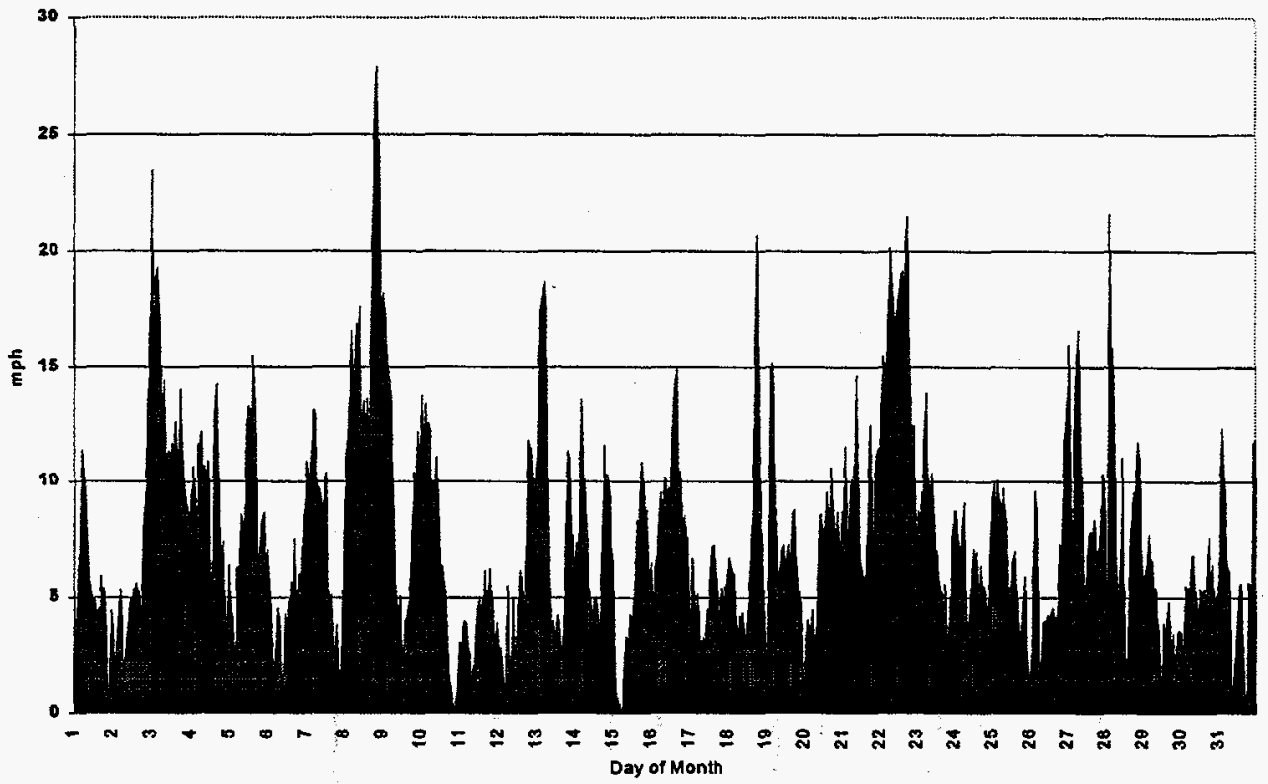

Fig. B.6. Hourly Mt. Constitution wind speed at 163'-August 1994. 


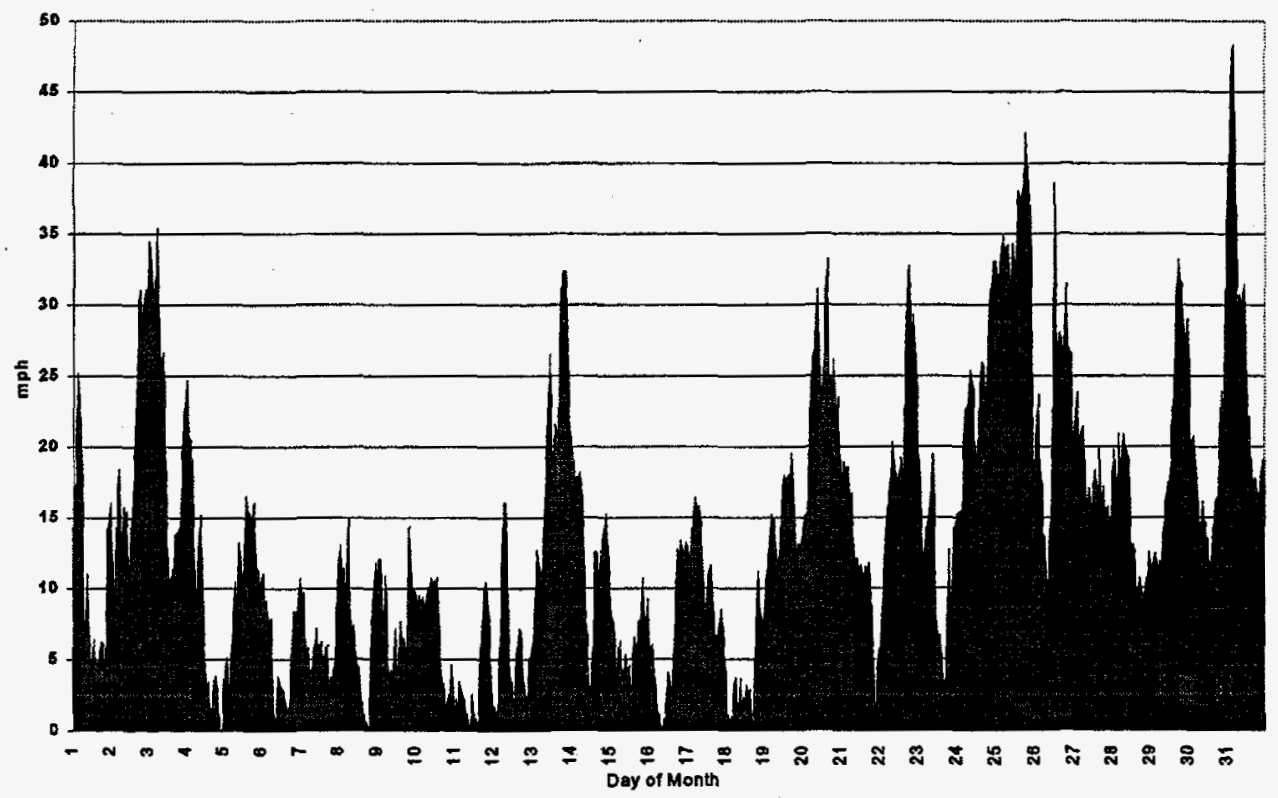

Fig. B.7. Hourly Mt. Constitution wind speed at 163'-September 1994.

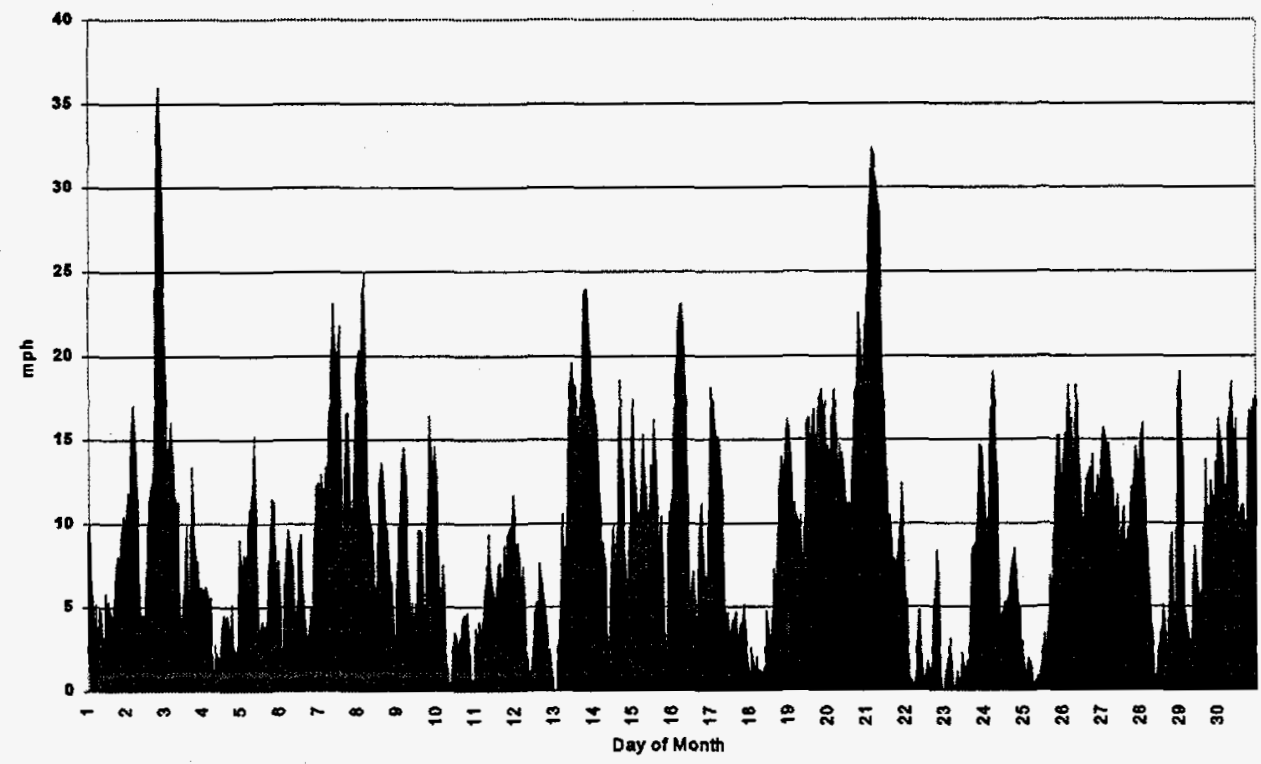

Fig. B.8. Hourly Mt. Constitution wind speed at $163^{\prime}$-October 1994. 


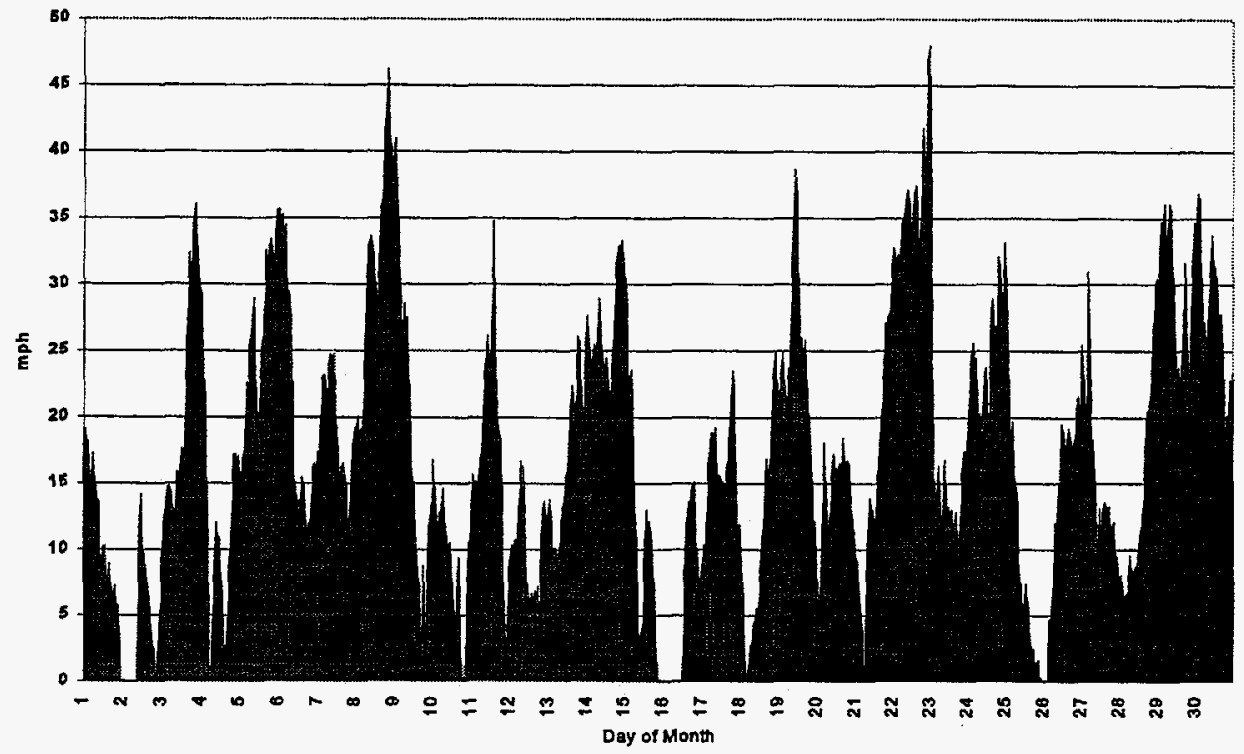

Fig. B.9. Hourly Mt. Constitution wind speed at 163'-November 1994.

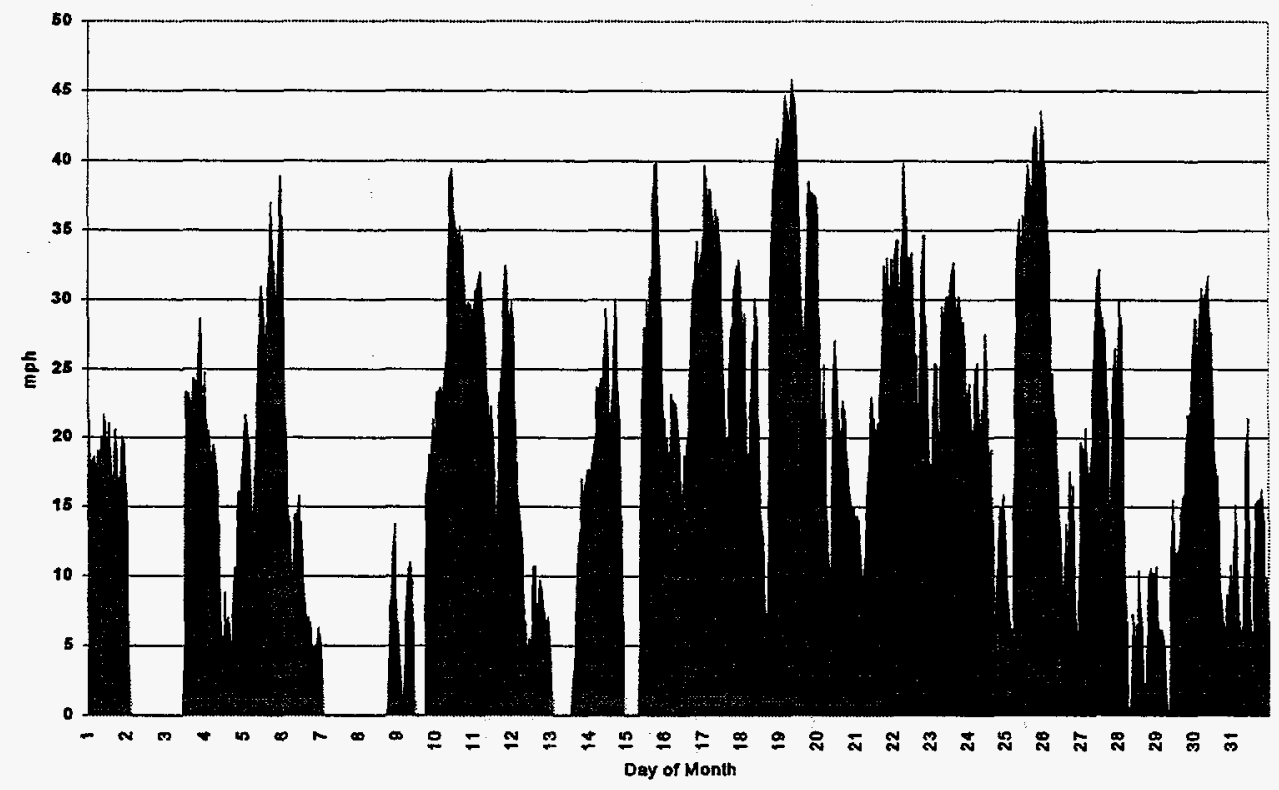

Fig. B.10. Hourly Mt. Constitution wind speed at 163'-December 1994. 


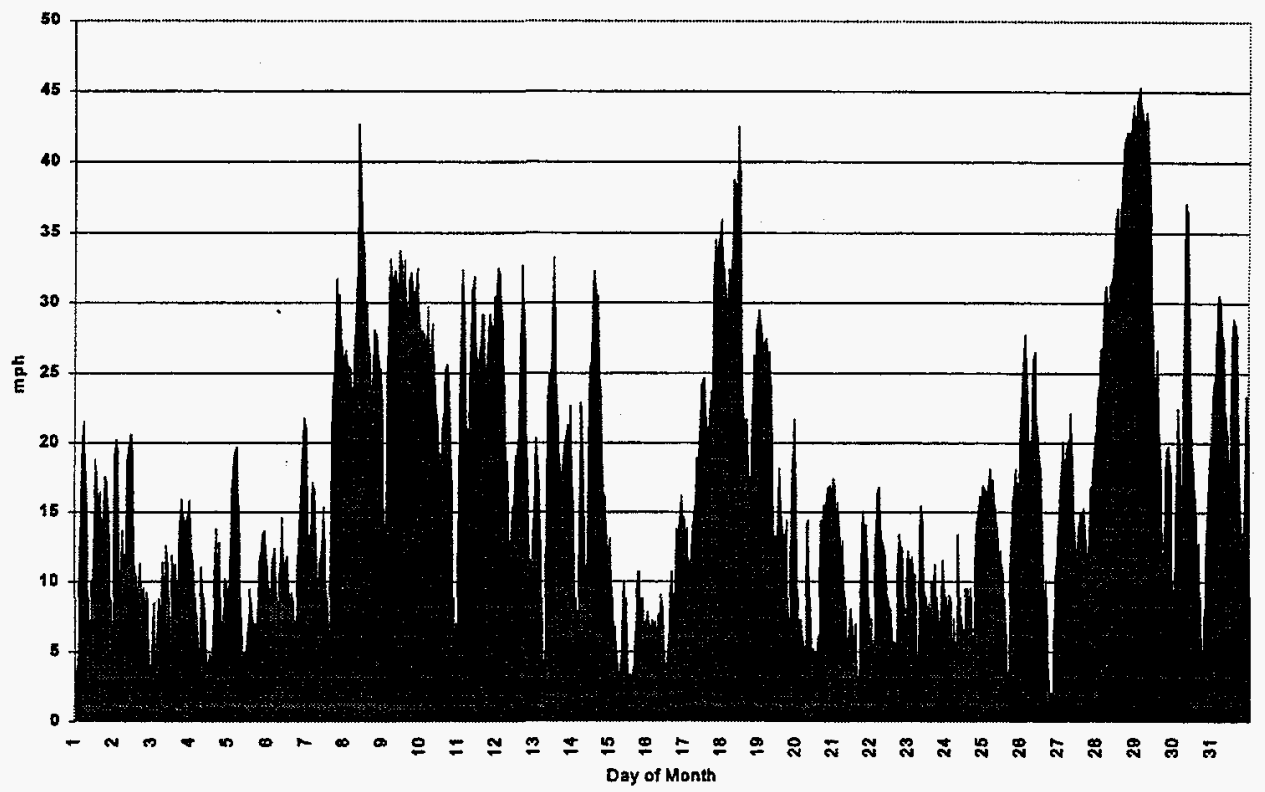

Fig. B.11. Hourly Mt. Constitution wind speed at $163^{\prime}$-January 1995.

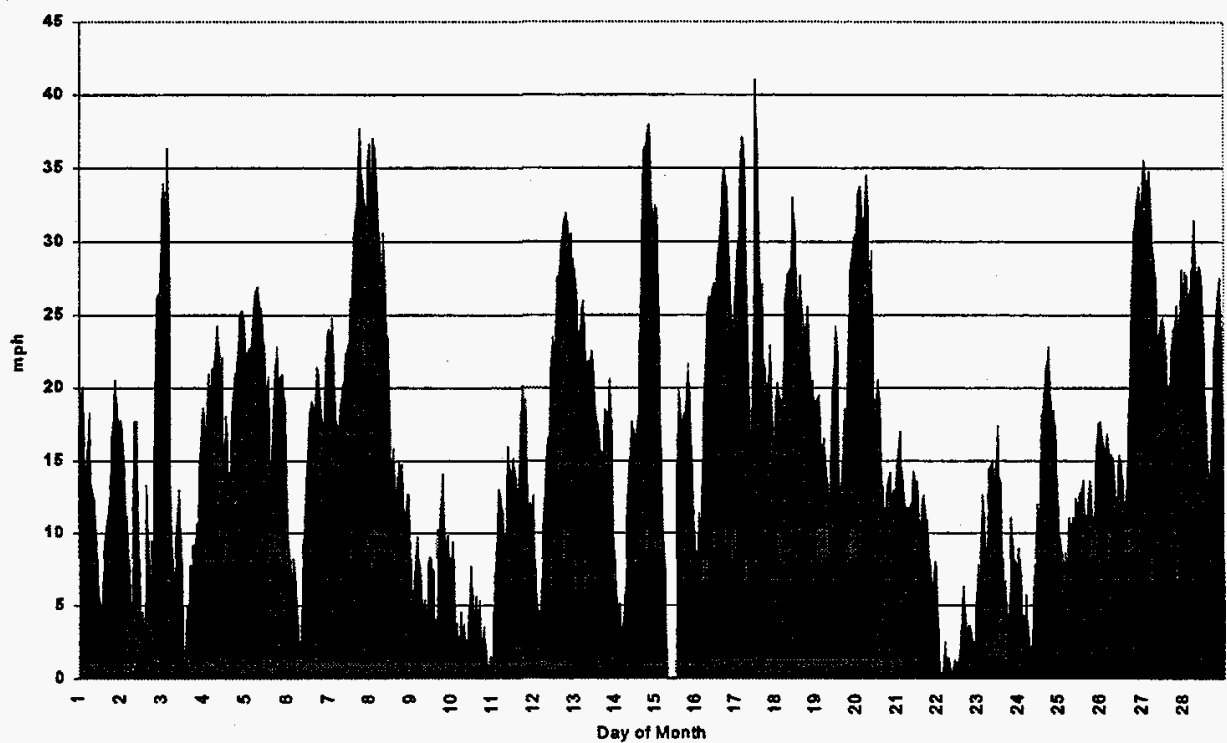

Fig. B.12. Hourly Mt. Constitution wind speed at 163'-February 1995. 


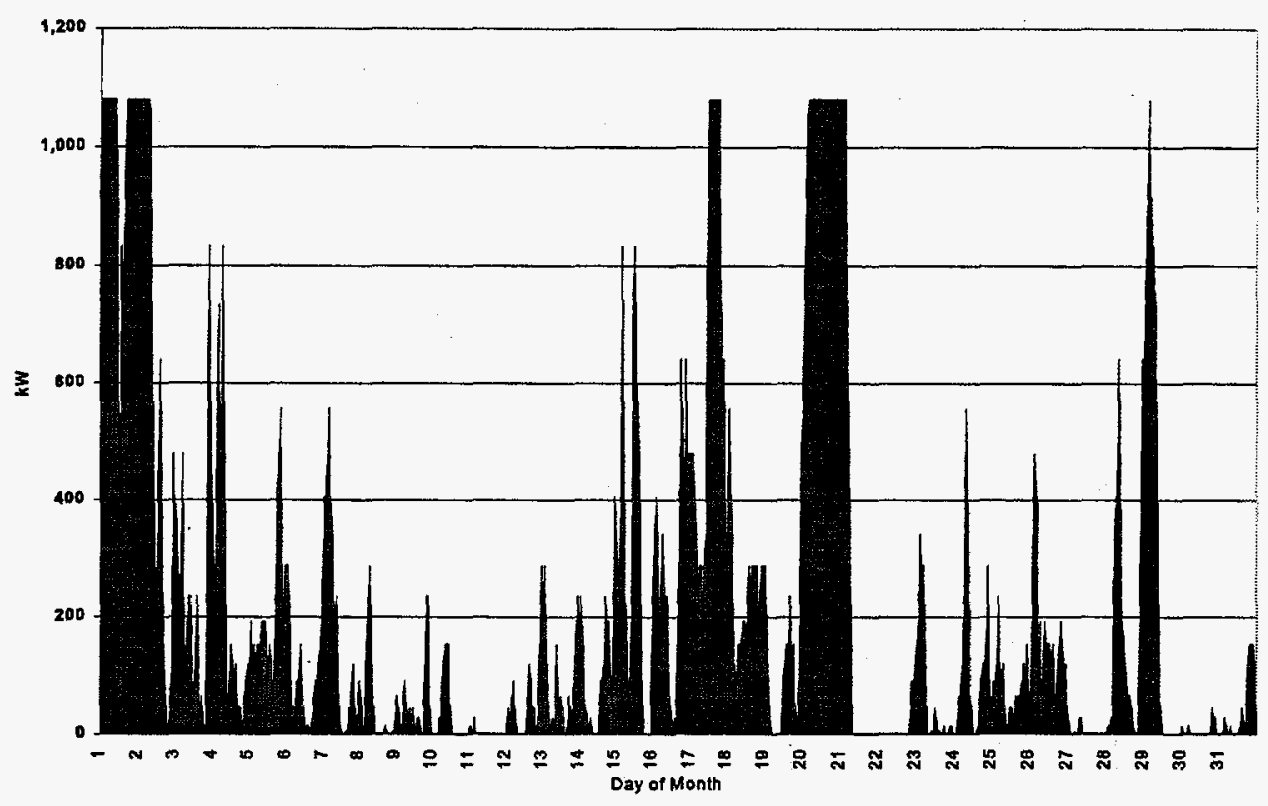

Fig. B.13. Hourly MW-scale wind plant performance at Mt. Constitution 163'-March 1994.

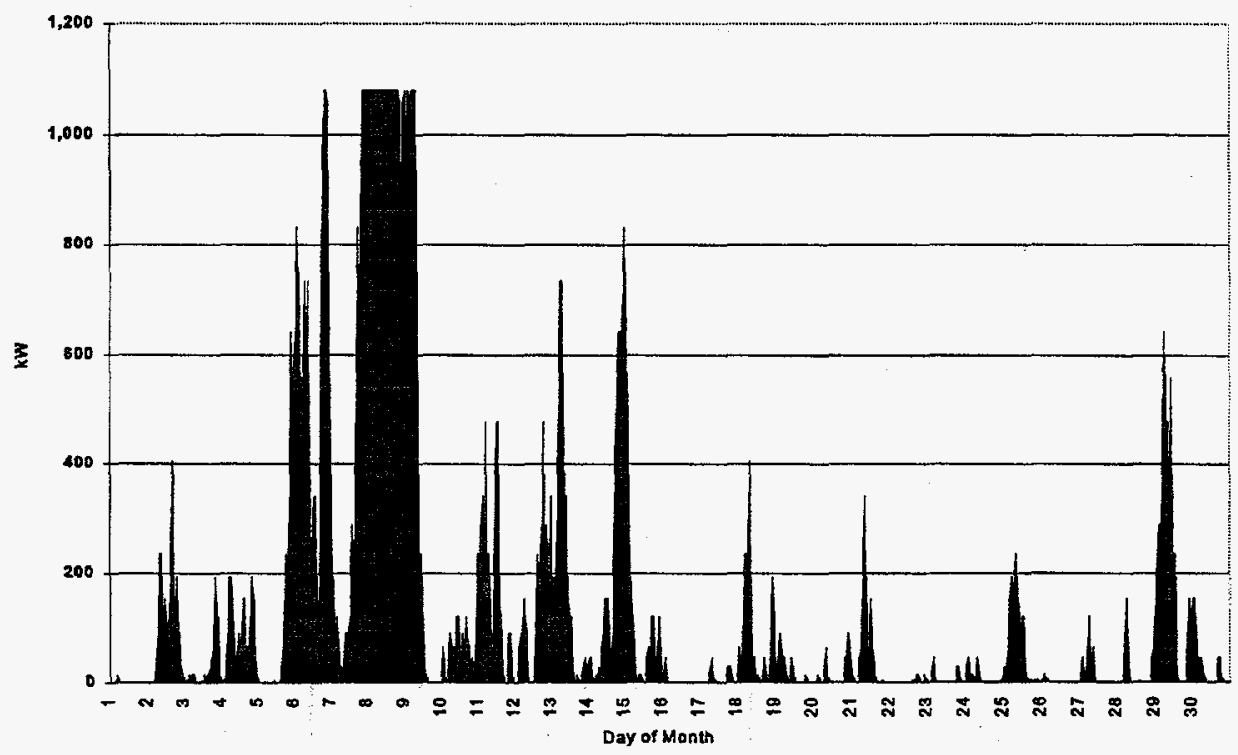

Fig. B.14. Hourly MW-Scale wind plant performance at Mt. Constitution 163'-April 1994. 


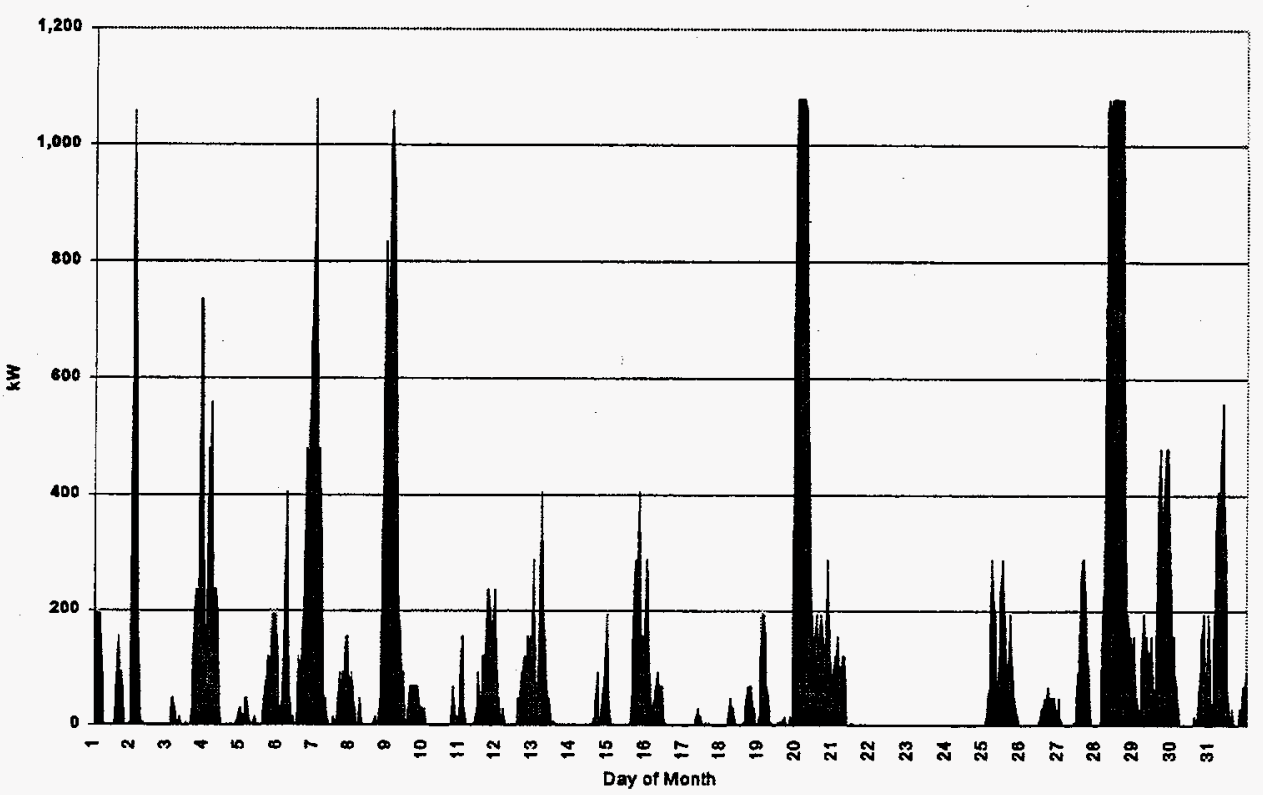

Fig. B.15. Hourly MW-scale wind plant performace at Mt. Constitution 163'-May 1994.

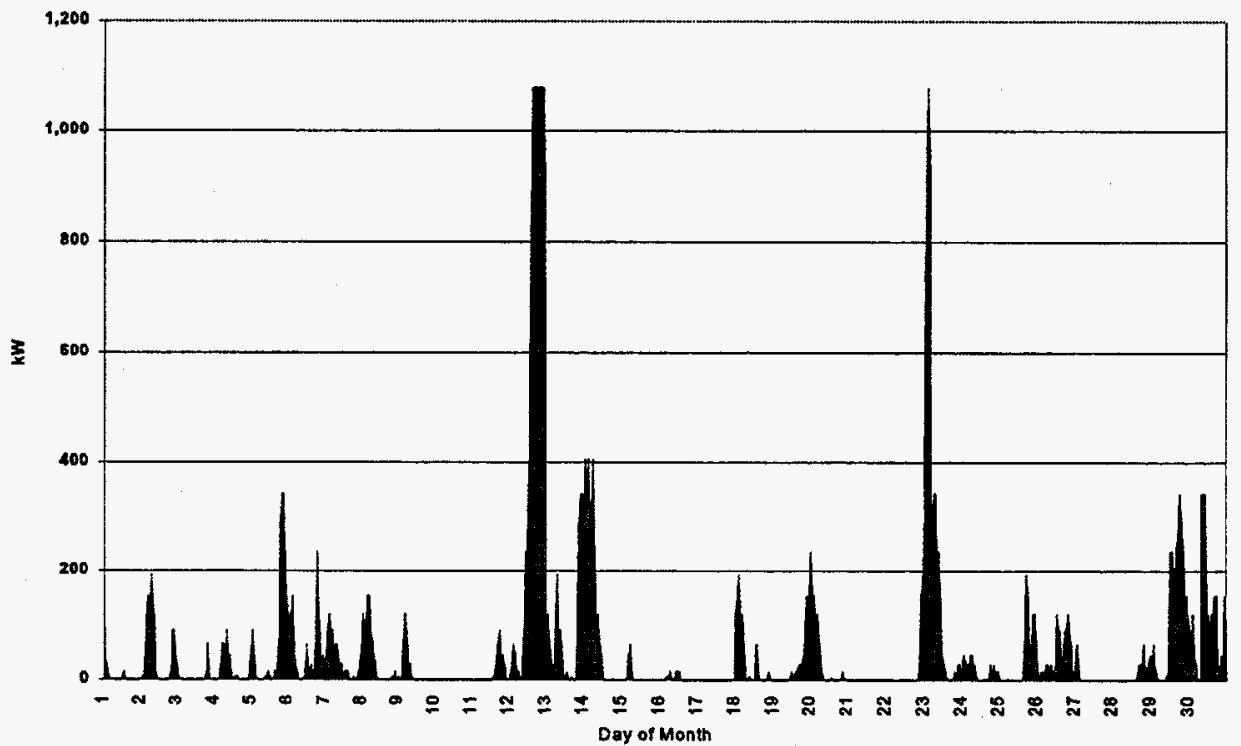

Fig. B.16. Hourly MW-scale wind plant performance at Mt. Constitution 163'-June 1994. 


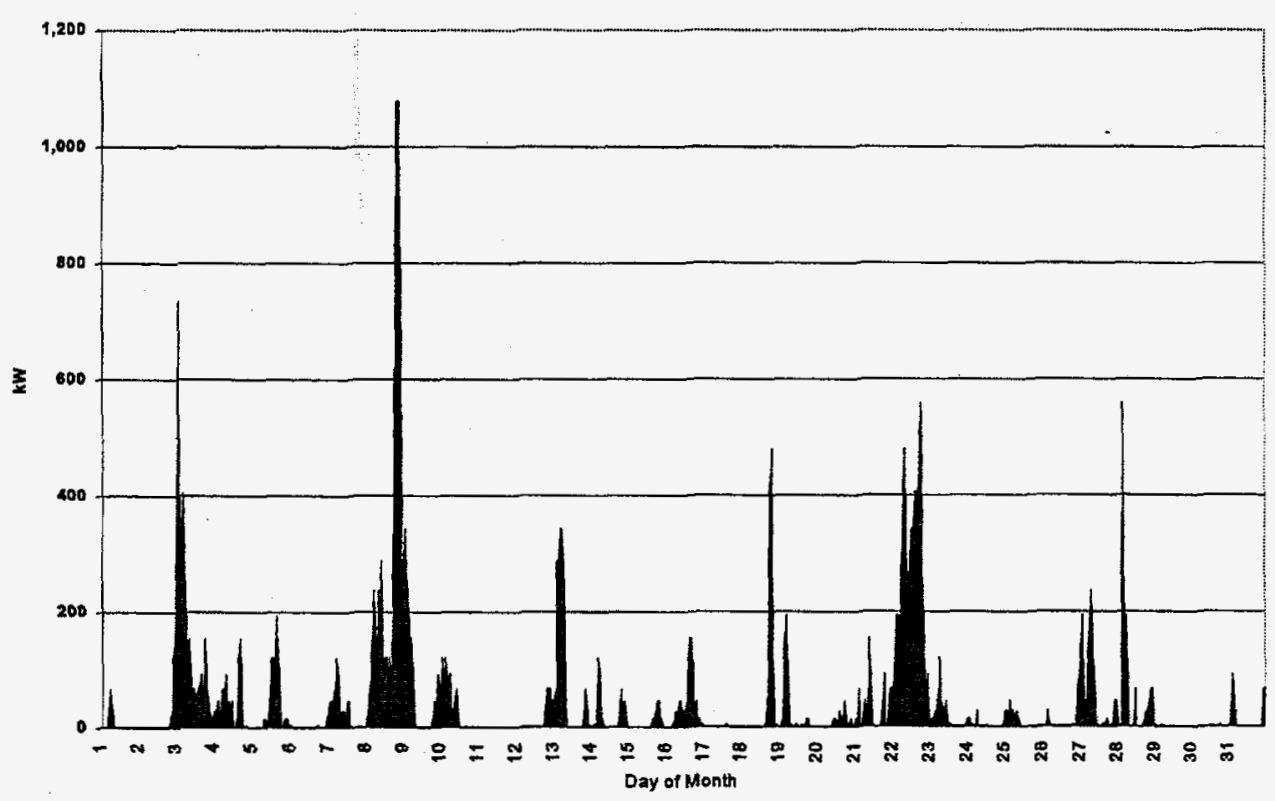

Fig. B.17. Hourly MW-scale wind plant performance: Mt. Constitution 163'-July 1994.

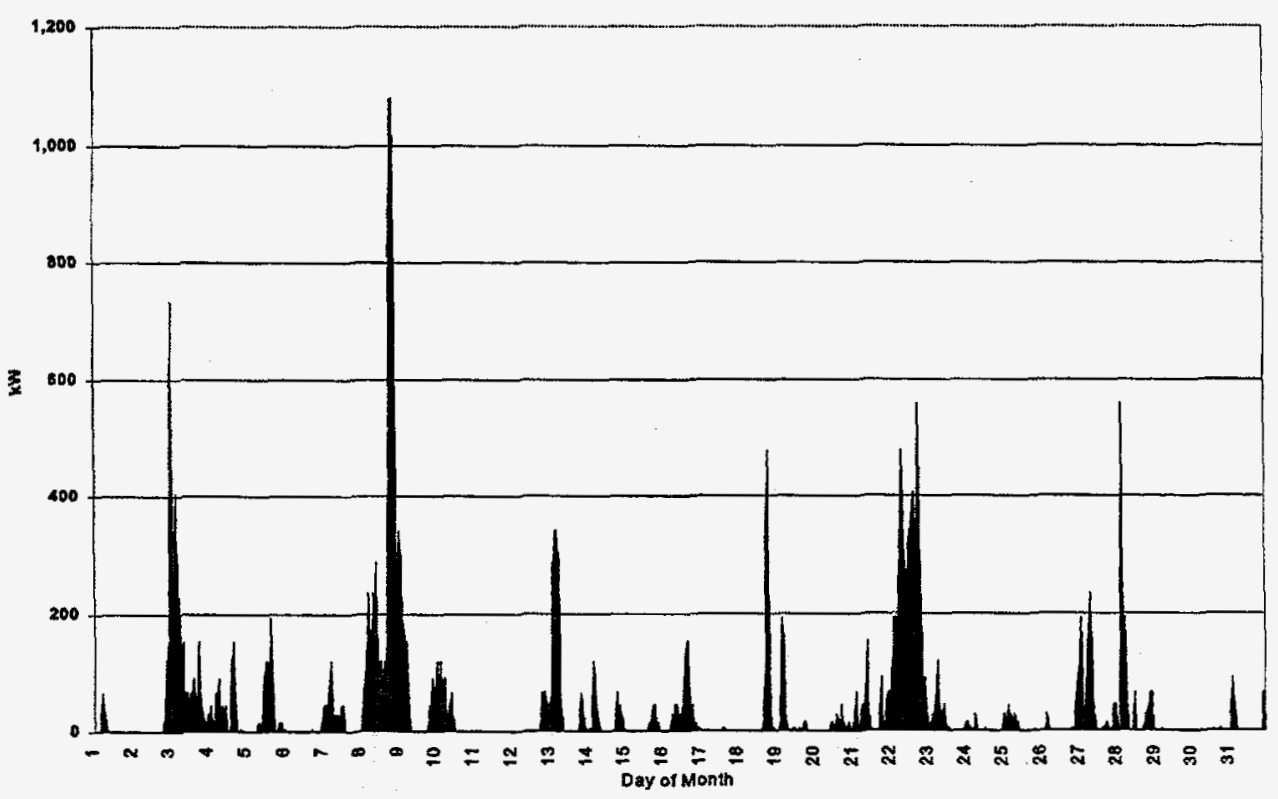

Fig. B.18. Hourly MW-scale wind plant performance: Mt. Constitution 163'-August 1994. 


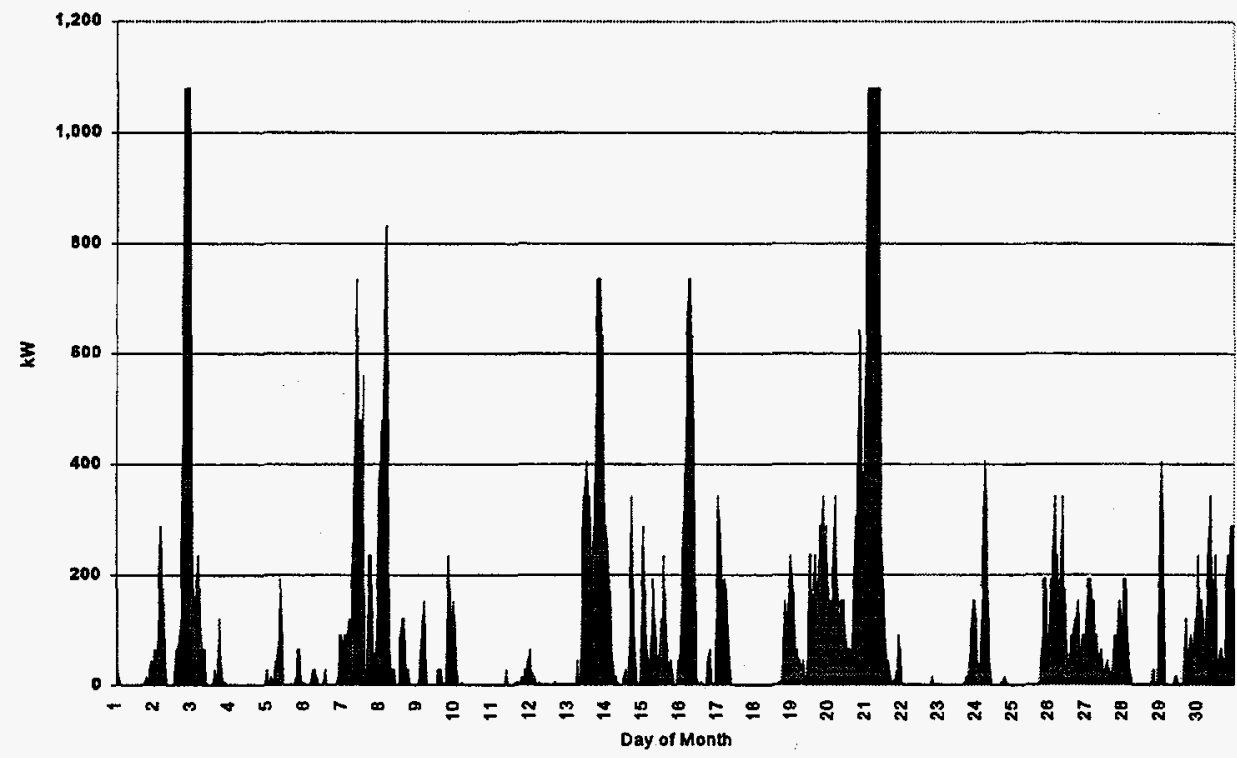

Fig. B.19. Hourly MW-scale wind plant performance: Mt. Constitution 163'-September 1994.

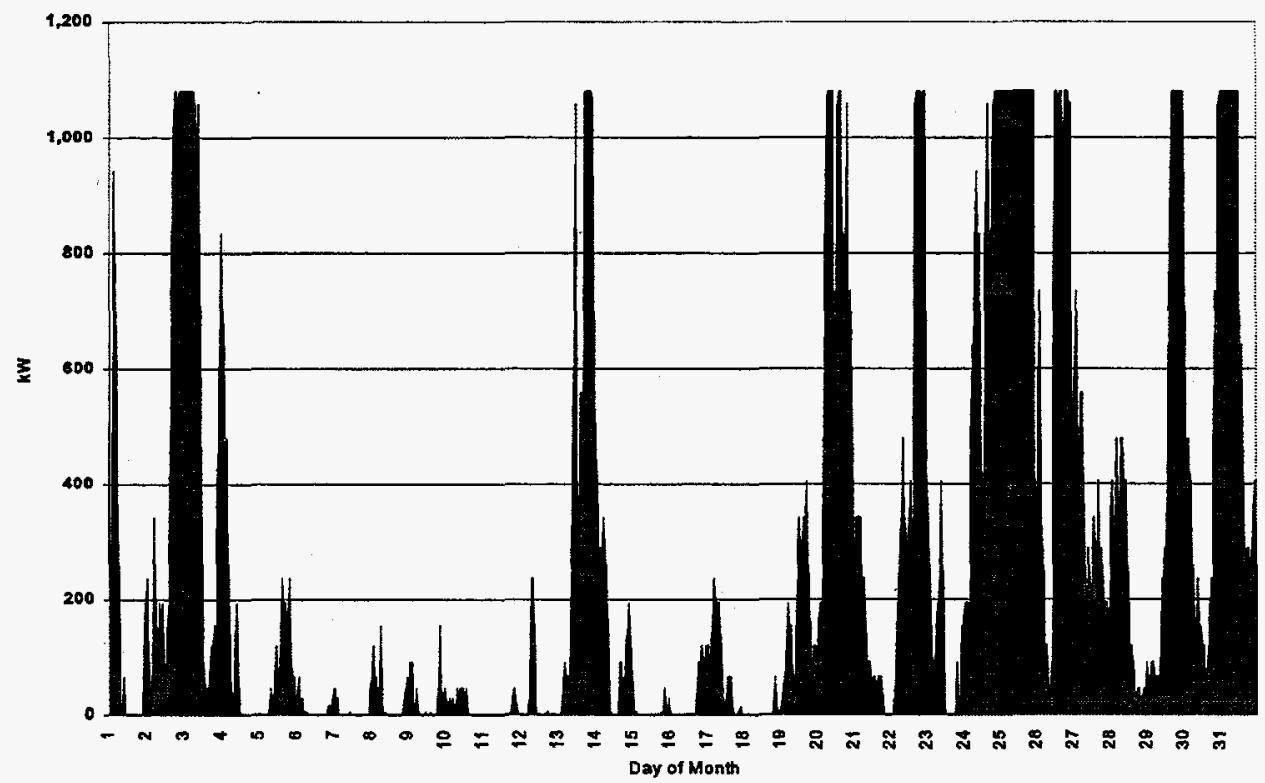

Fig. B.20. Hourly MW-scale wind plant performance: Mt. Constitution 163'-October 1994. 


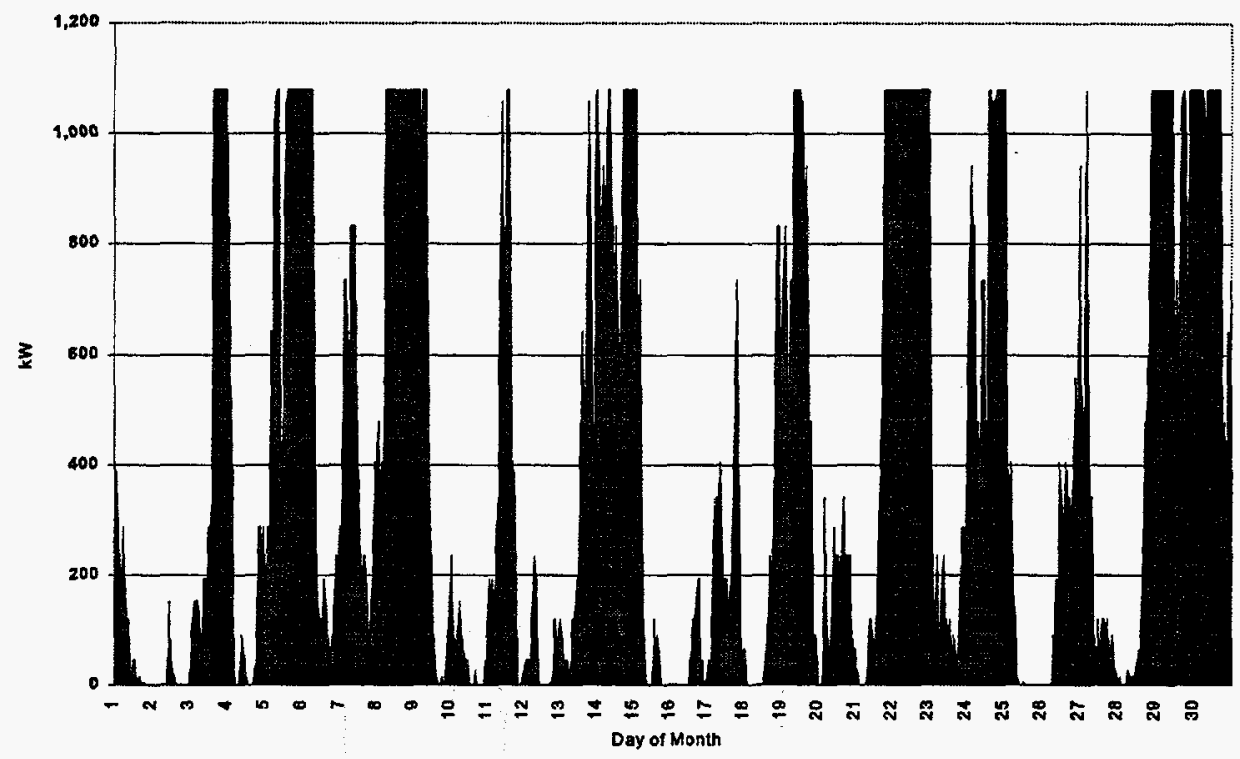

Fig. B.21. Hourly MW-scale wind plant performance: Mt. Constitution 163'-November 1994.

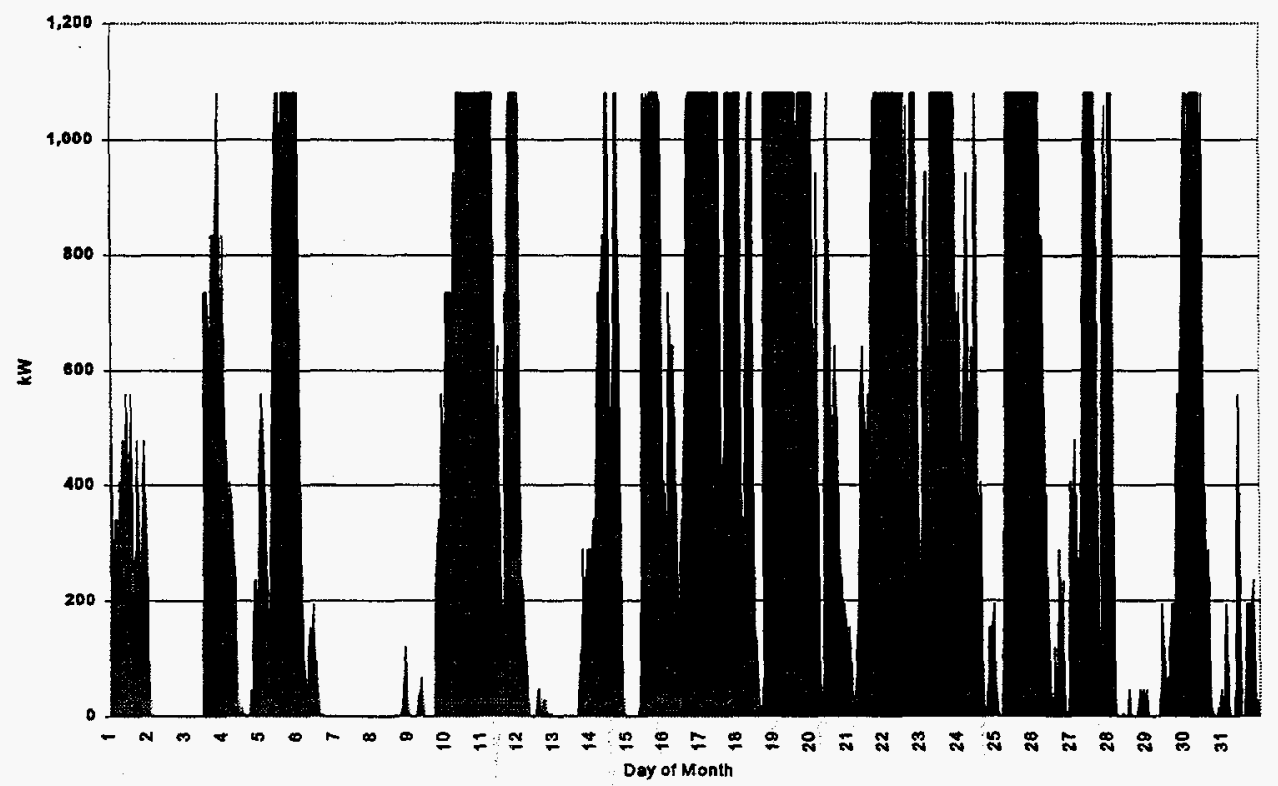

Fig. B.22. Hourly MW-scale wind plant performance: Mt. Constitution 163'-December 1994. 


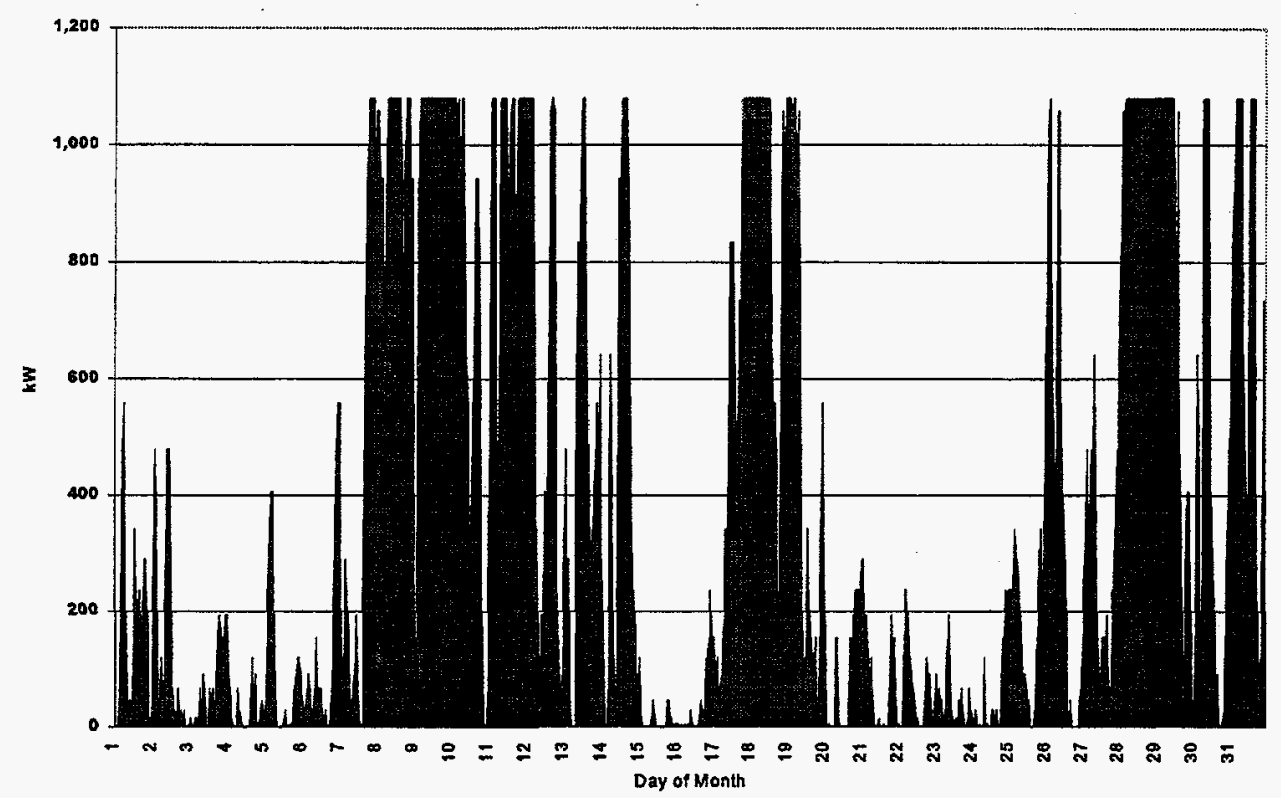

Fig. B.23. Hourly MW-scale wind plant performance: Mt. Constitution 163'-January 1995.

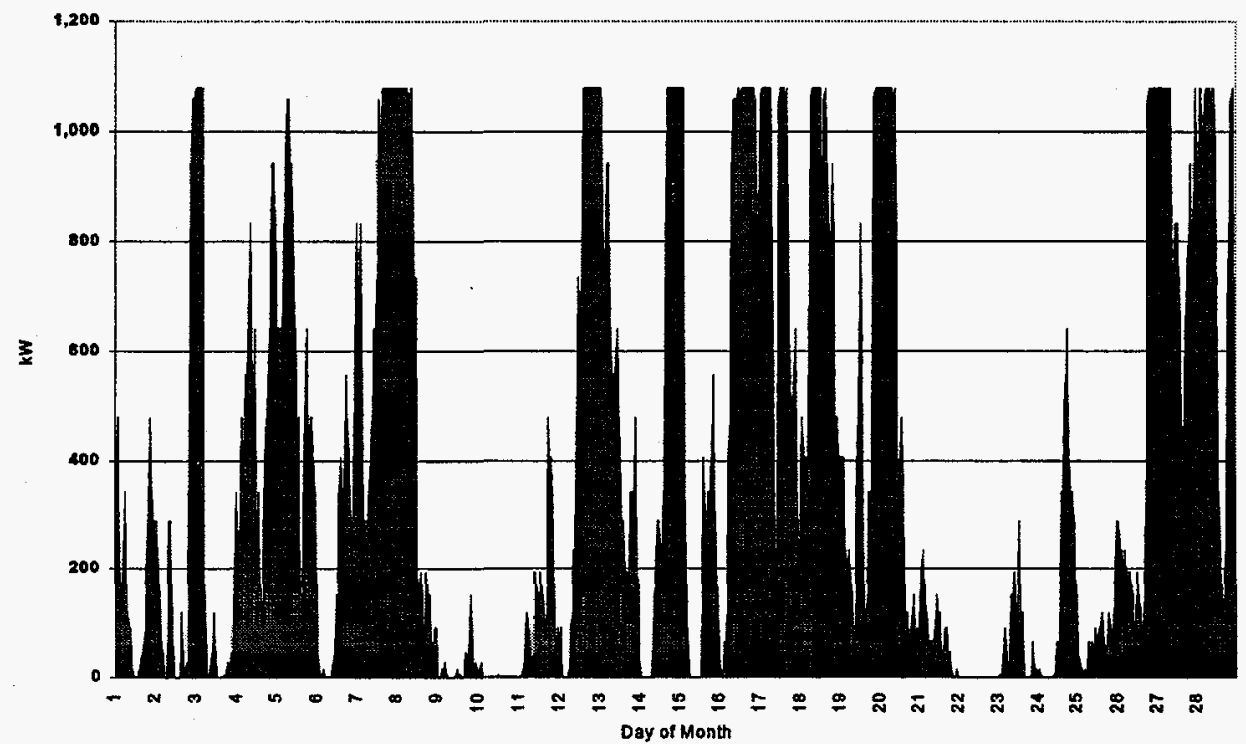

Fig. B.24. Hourly MW-scale wind plant performance: Mt. Constitution 163'-February 1995. 


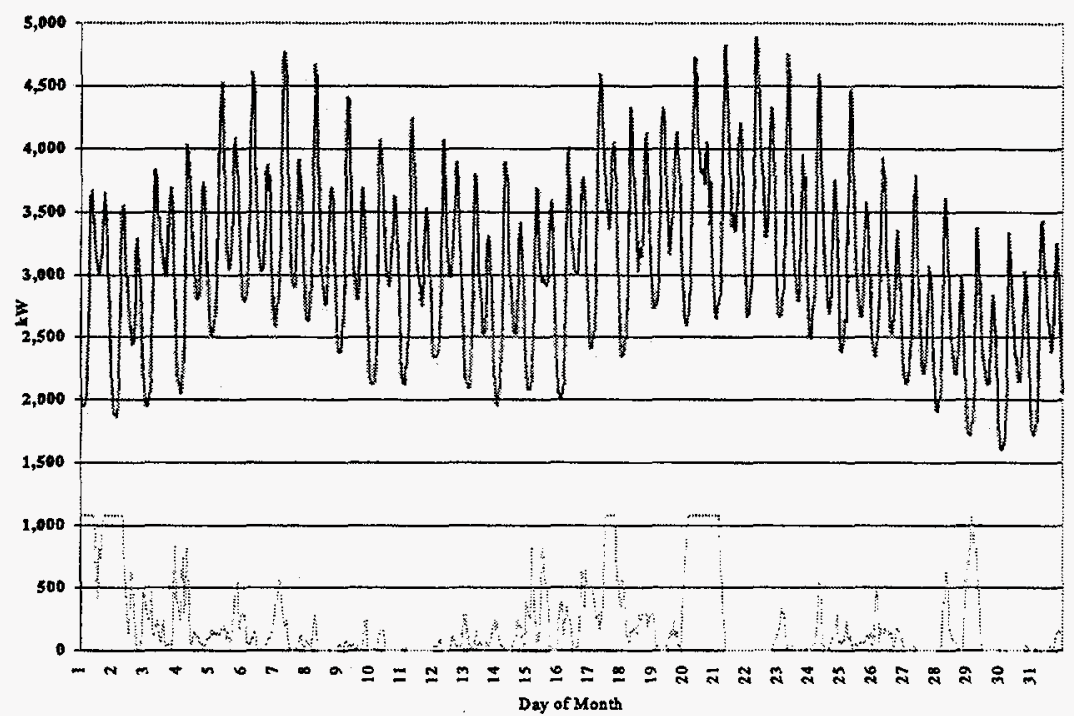

-Lond W..... WT Outpot

Fig. B.25. Correlation between Eastsound load and MW-scale wind farm performance: Mt. Constitution 163' —March 1994.

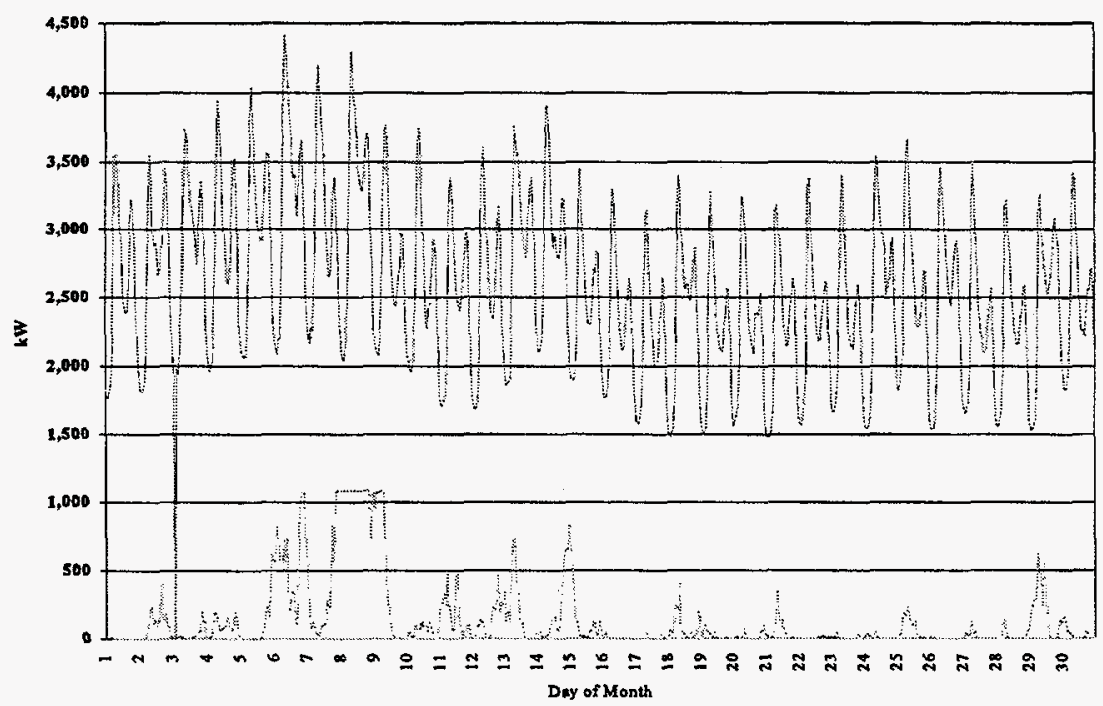

Fig. B.26. Correlation between Eastsound load and MW-scale wind farm performance: Mt. Constitution 163' -April 1994. 


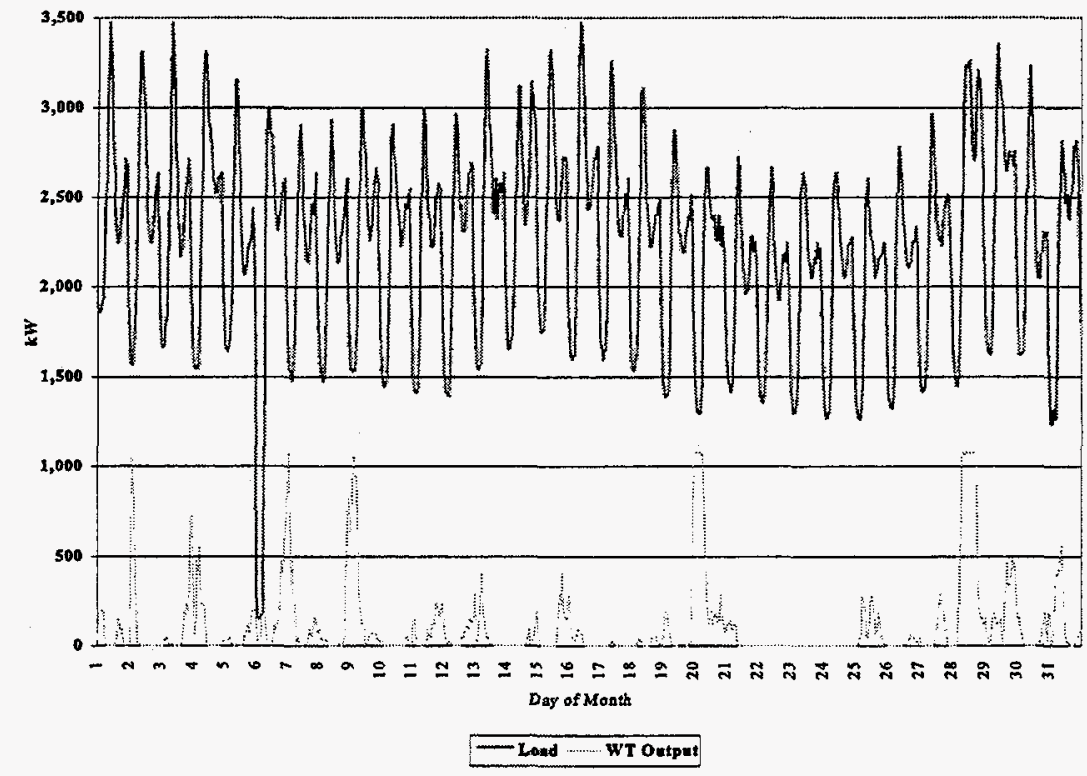

Fig. B.27. Correlation between Eastsound load and MW-scale wind farm performance: Mt. Constitution 163' -May 1994.

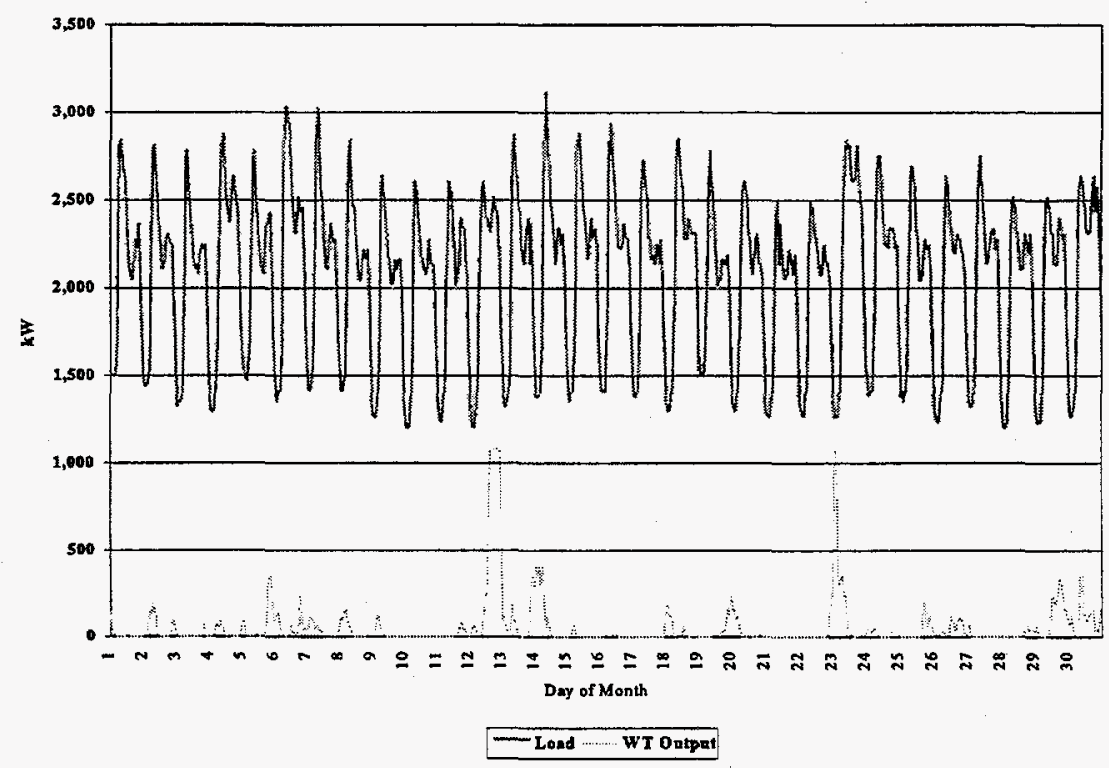

Fig. B.28. Correlation between Eastsound load and MW-scale wind farm performance: Mt. Constitution 163' -June 1994. 


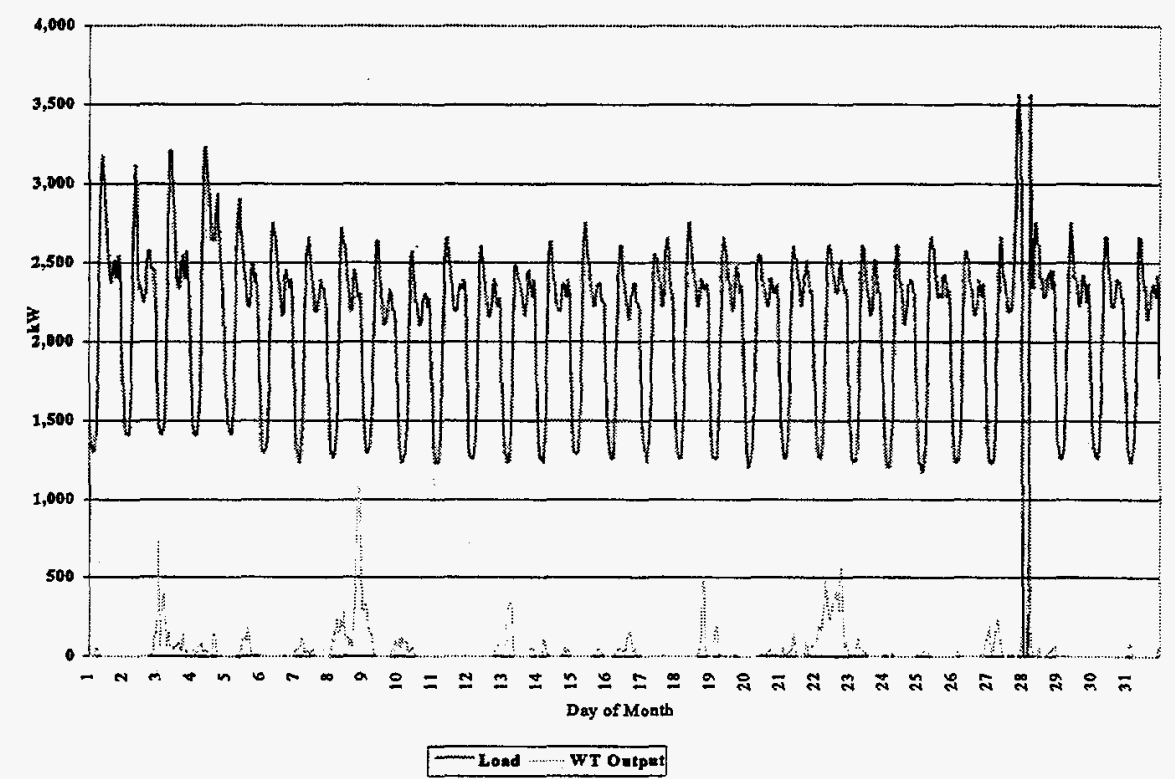

Fig. B.29. Correlation between Eastsound load and MW-scale wind farm performance: Mt. Constitution 163' -July 1994.

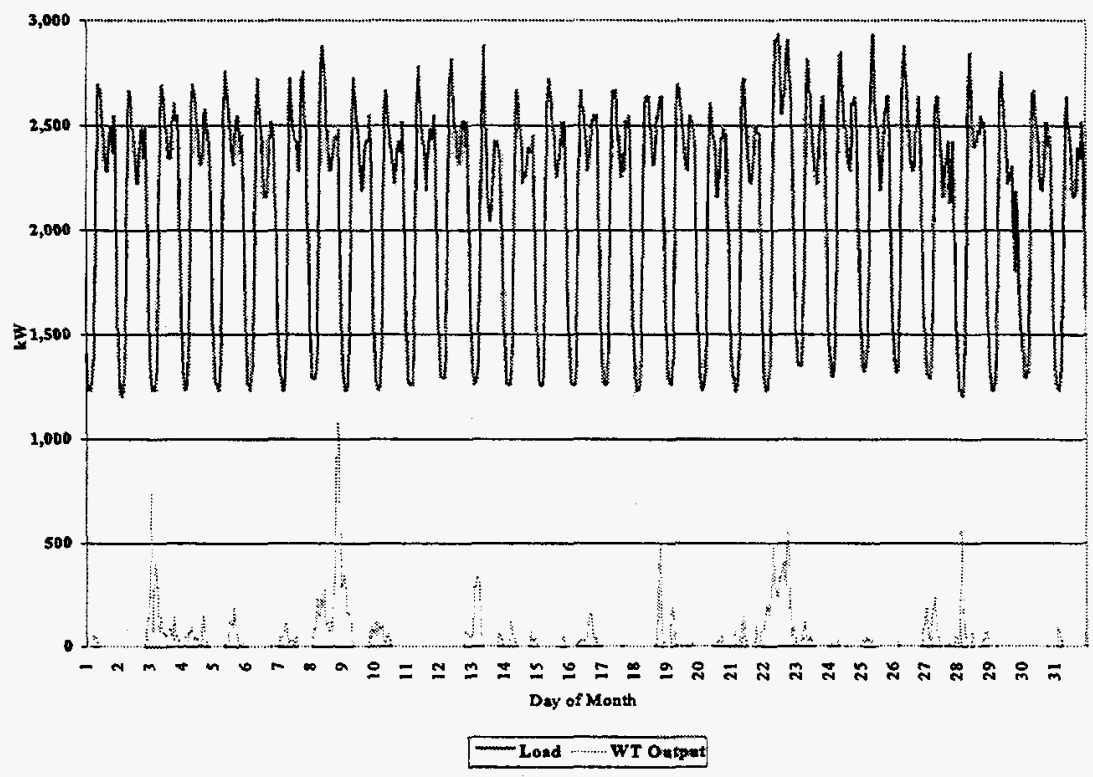

Fig. B.30. Correlation between Eastsound load and MW-scale wind farm performance: Mt. Constitution 163' -August 1994. 


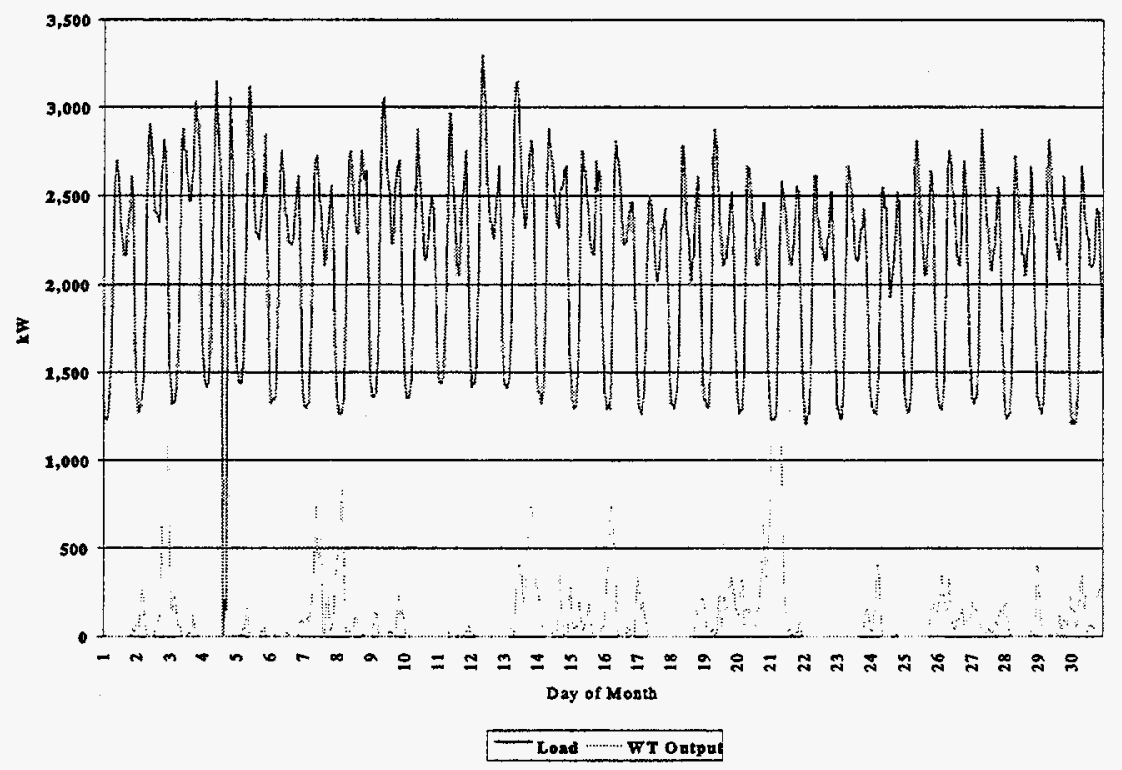

Fig. B.31. Correlation between Eastsound load and MW-scale wind farm performance: Mt. Constitution 163' -September 1994.

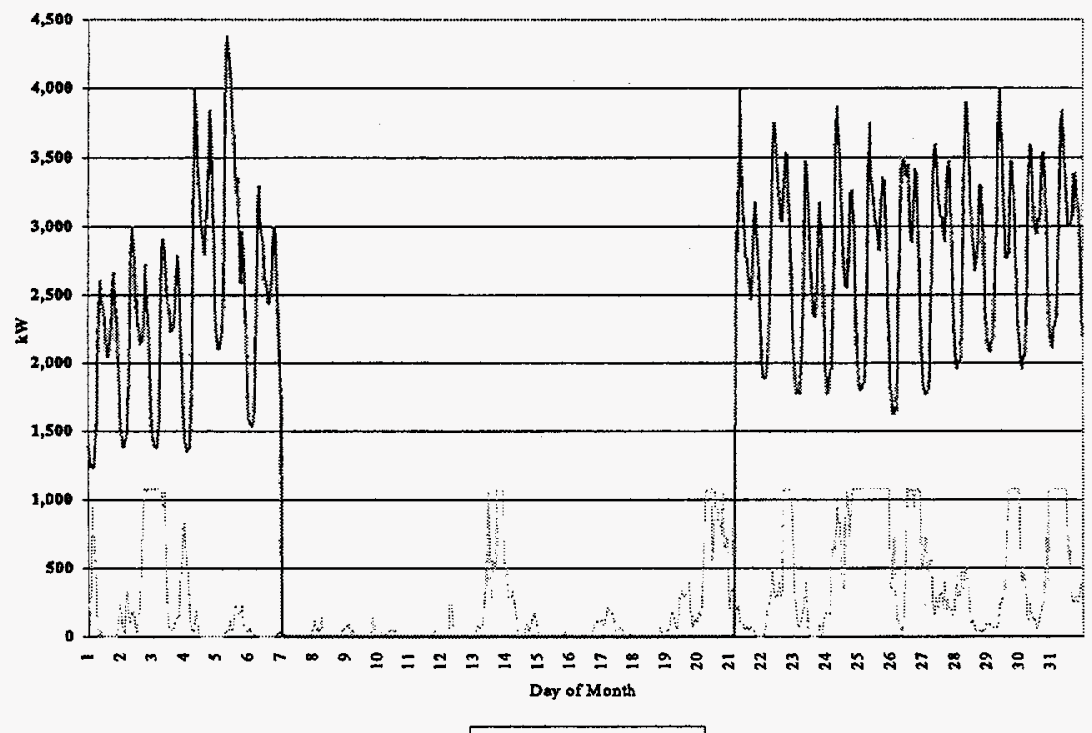

Fig. B.32. Correlation between Eastsound load and MW-scale wind farm performance: Mt. Constitution 163' -October 1994. 


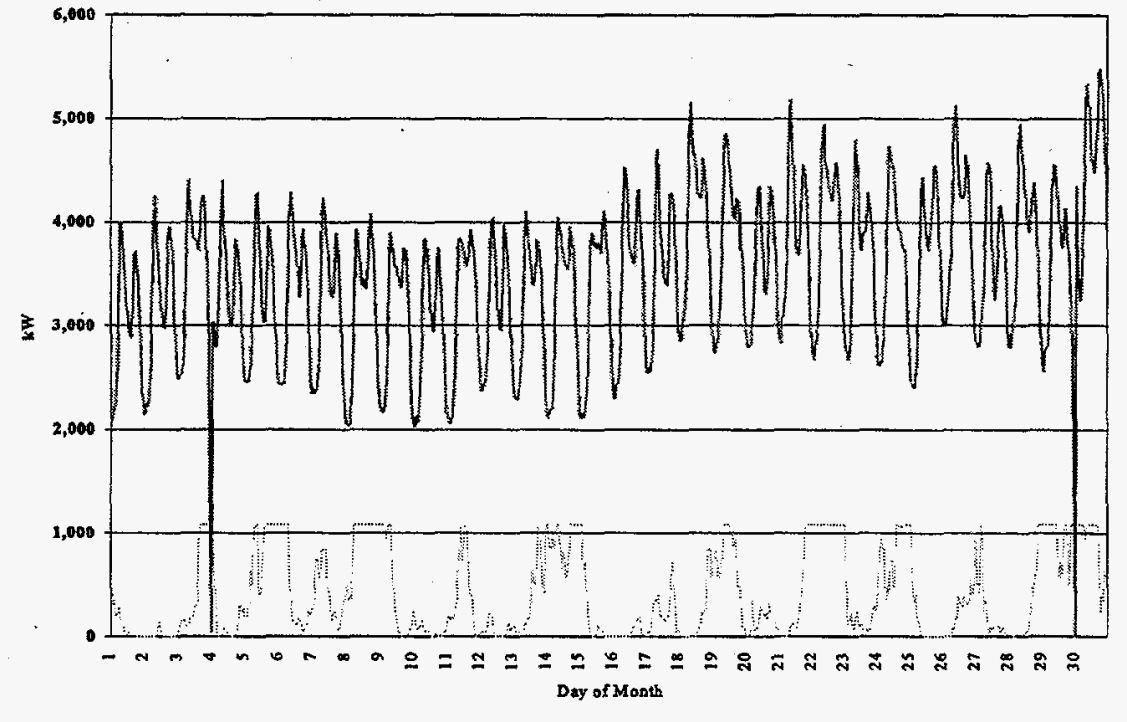

- Losd ….... WT Oextpat

Fig. B.33. Correlation between Eastsound load and MW-scale wind farm performance: Mt. Constitution 163' - November 1994.

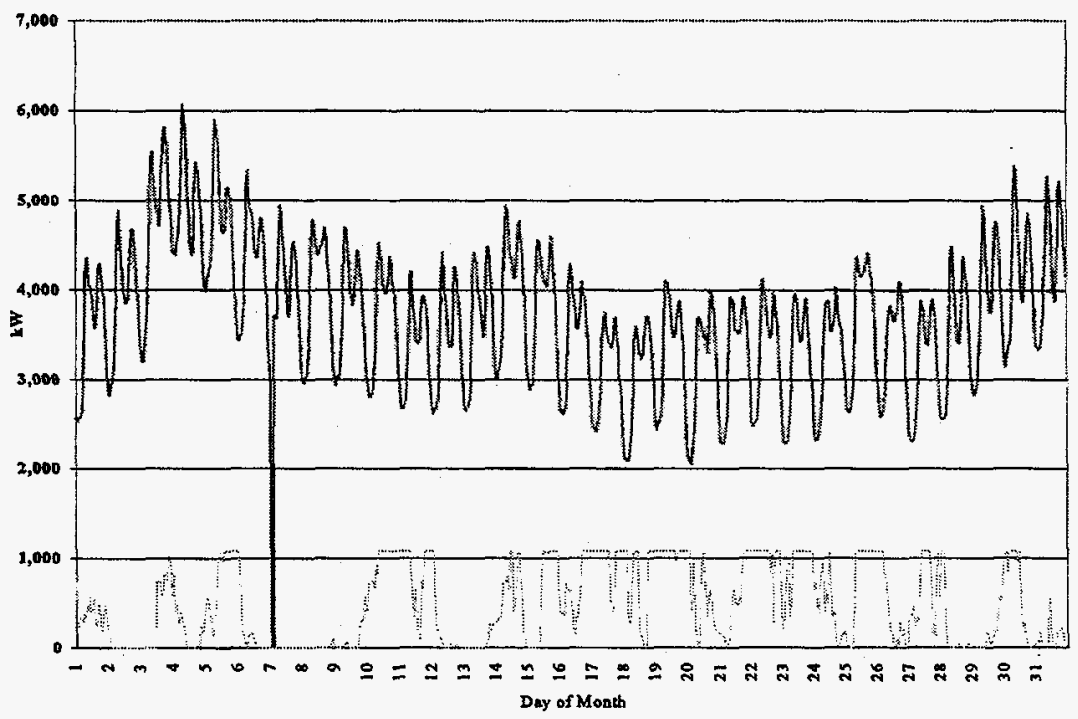

Wond -..... WT Oetpet

Fig. B.34. Correlation Between Eastsound Load and MW-scale wind farm Performance: Mt. Constitution 163' -December 1994. 


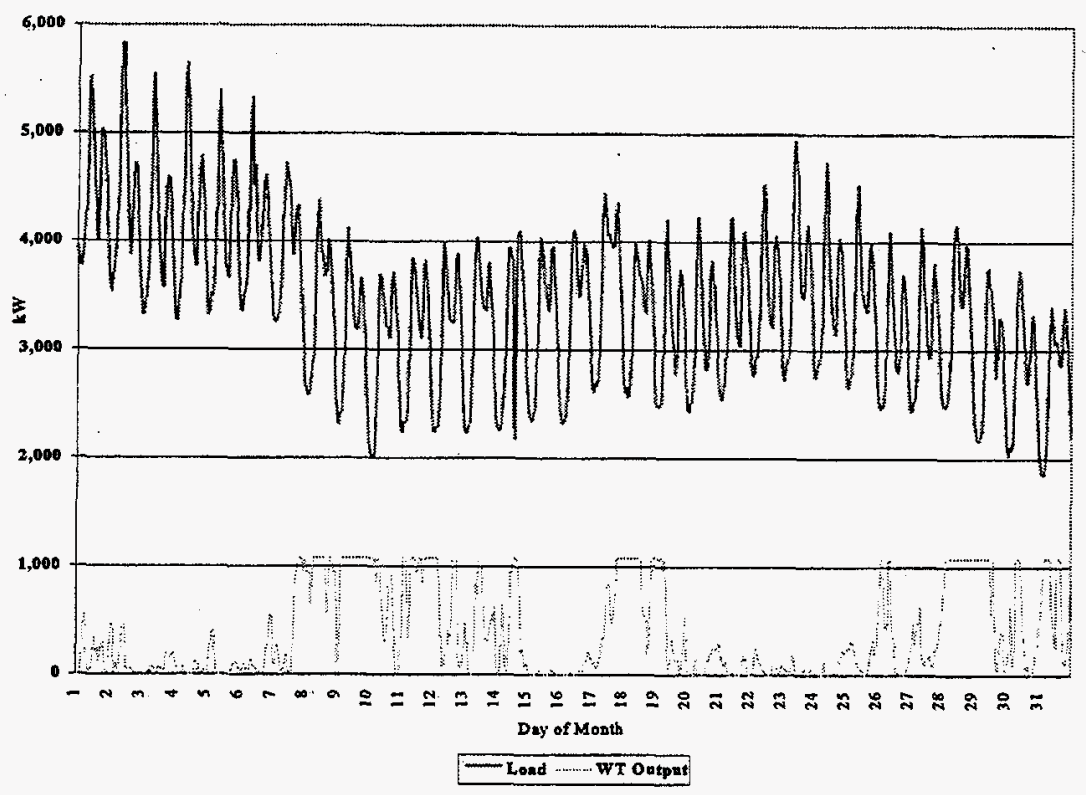

Fig. B.35. Correlation between Eastsound load and MW-scale wind farm performance: Mt. Constitution 163' —January 1995.

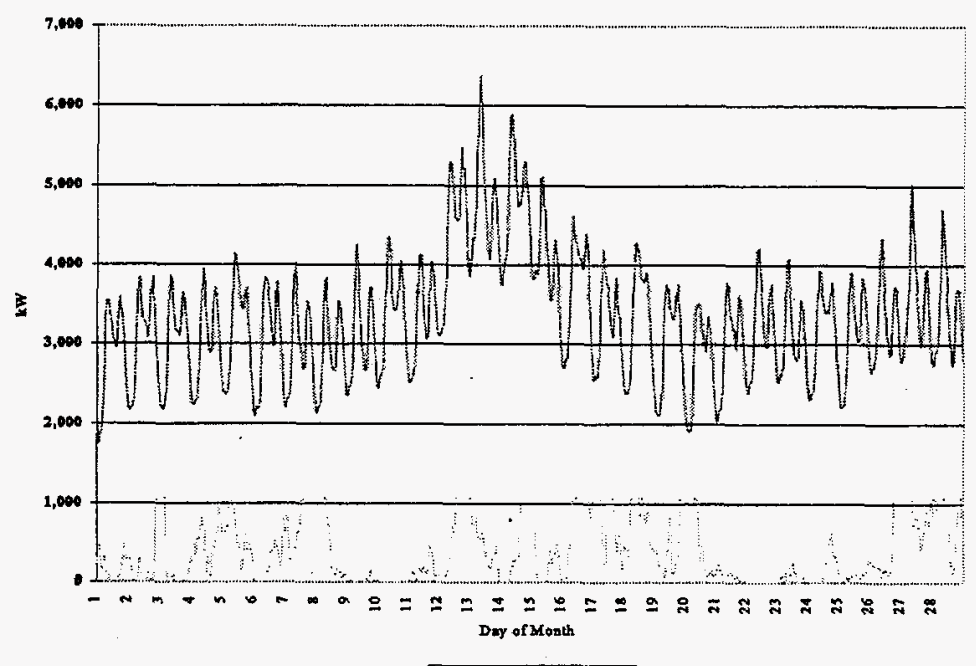

Iond ........WT Ontput

Fig. B.36. Correlation between Eastsound load and MW-scale wind farm performance: Mt. Constitution 163' -February 1995. 


\section{APPENDIX C}

\section{HOURLY WIND AND MW-SCALE WIND PLANT PERFORMANCE- MT. CONSTITUTION 120'}

Hourly wind data were collected near the top of Mt. Constitution at 163' and at $120^{\prime}$ above the ground. Figures C.1 through C.12 present the hourly winds monthly from March 1994 through February 1995 at the $120^{\prime}$ level. Wind data for August 1994 were lost. For this study, hourly wind data for July 1994 (Figure C.5) were also assumed for August 1994 (Figure C.6).

Resulting hourly MW-scale wind plant performance are presented in Figures C.13 through C.24 for March 1994 through February 1995 assuming the above wind data, three $350 \mathrm{~kW}$ variable speed wind turbines, and the wind-power curve presented in Figure 3.1.

Figures C. 25 through C. 36 illustrate the resulting hourly correlation of a MW-scale wind plant output with the hourly Eastsound loads from March 1994 through February 1995. 


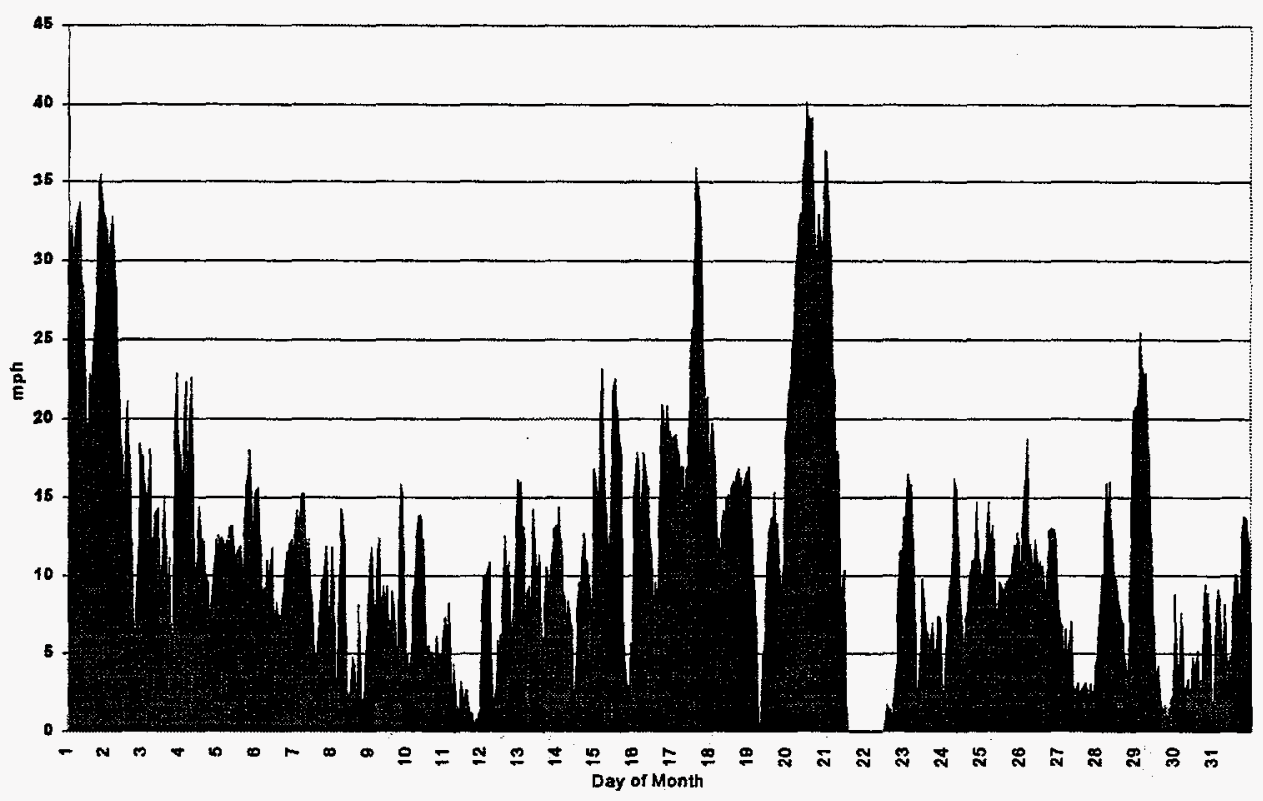

Fig. C.1. Hourly Mt. Constitution wind speed at 120'-March 1994.

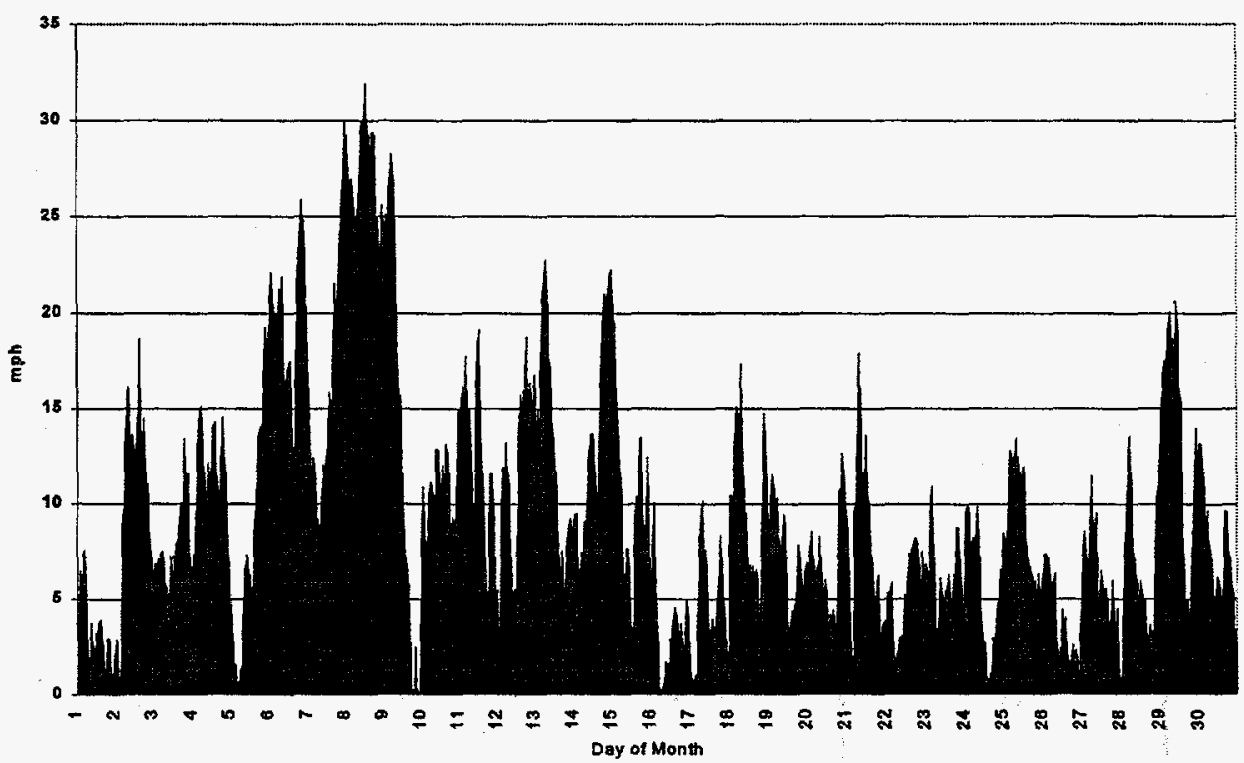

Fig. C.2. Hourly Mt. Constitution wind speed at 120'-April 1994. 


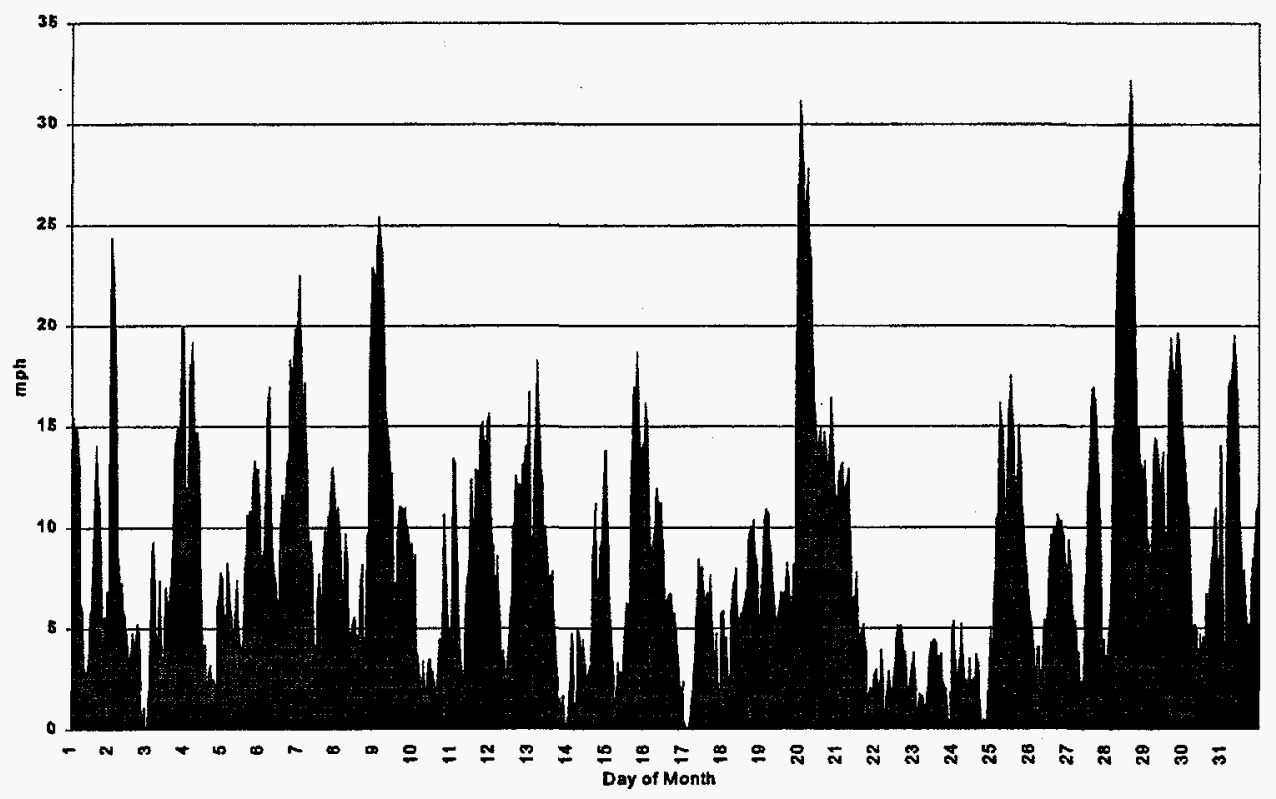

Fig. C.3. Hourly Mt. Constitution wind speed at 120'-May 1994.

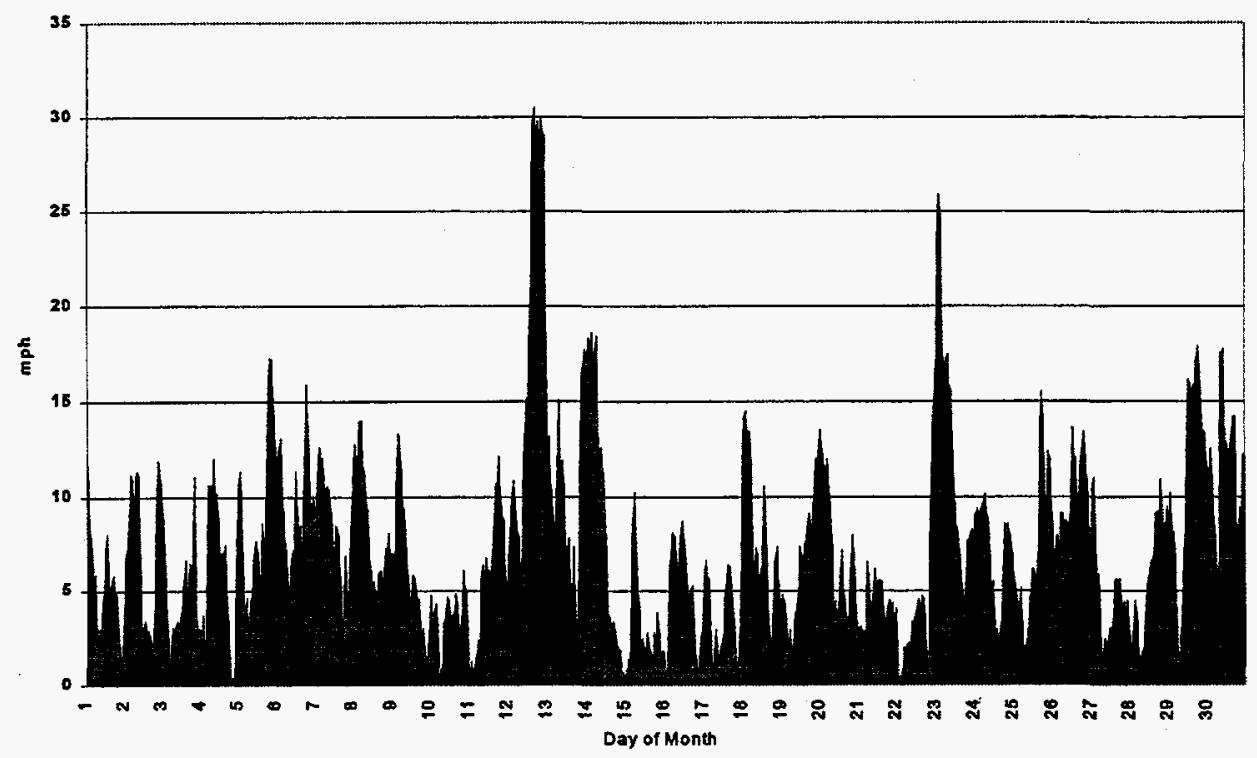

Fig. C.4. Hourly Mt. Constitution wind speed at 120'-June 1994. 


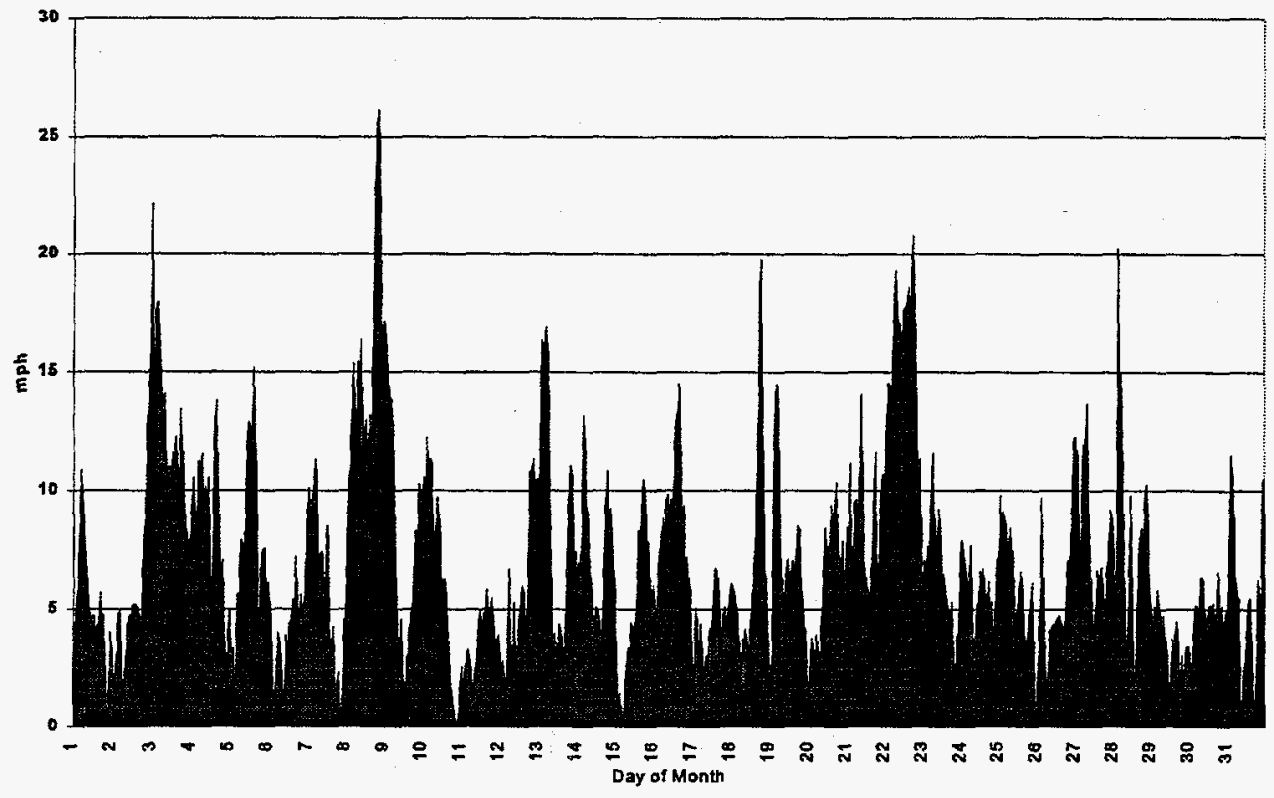

Fig. C.5. Hourly Mt. Constitution wind speed at 120'-July 1994.

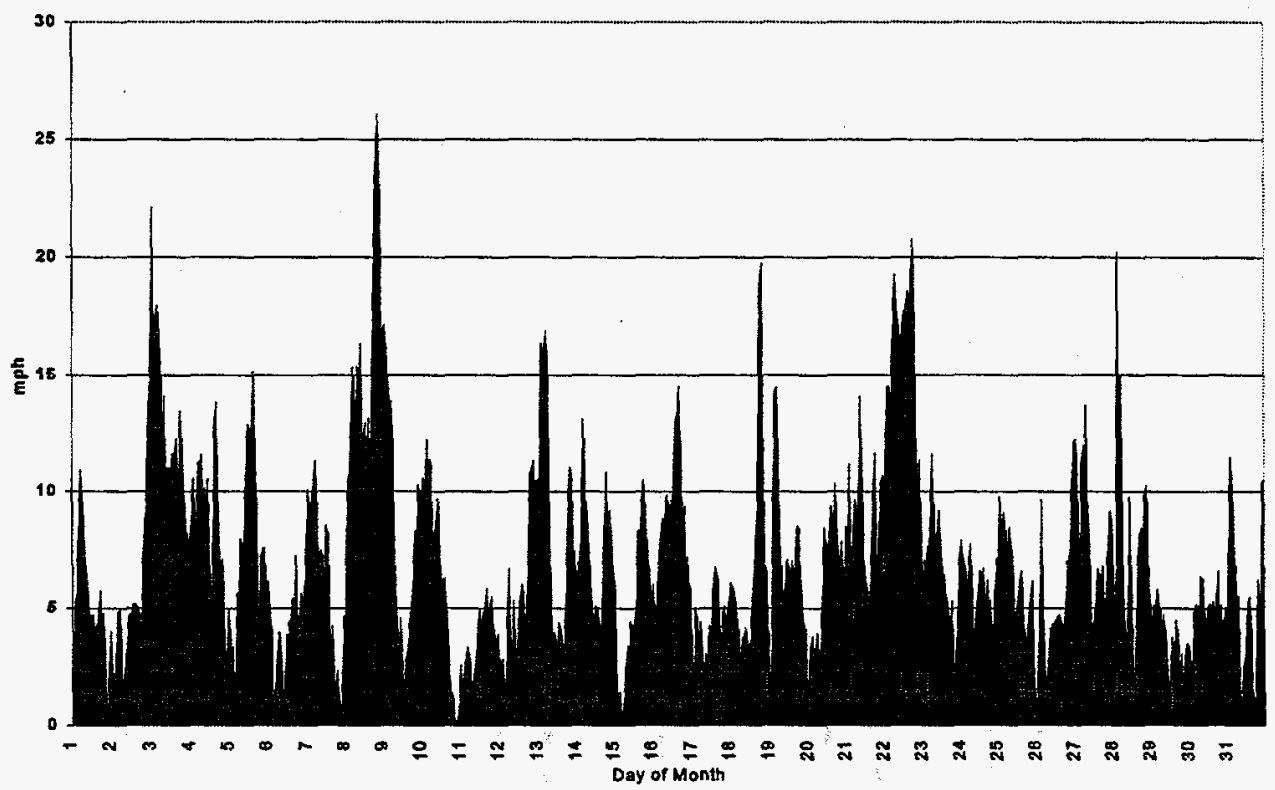

Fig. C.6. Hourly Mt. Constitution wind speed at $120^{\prime}$-August 1994. 


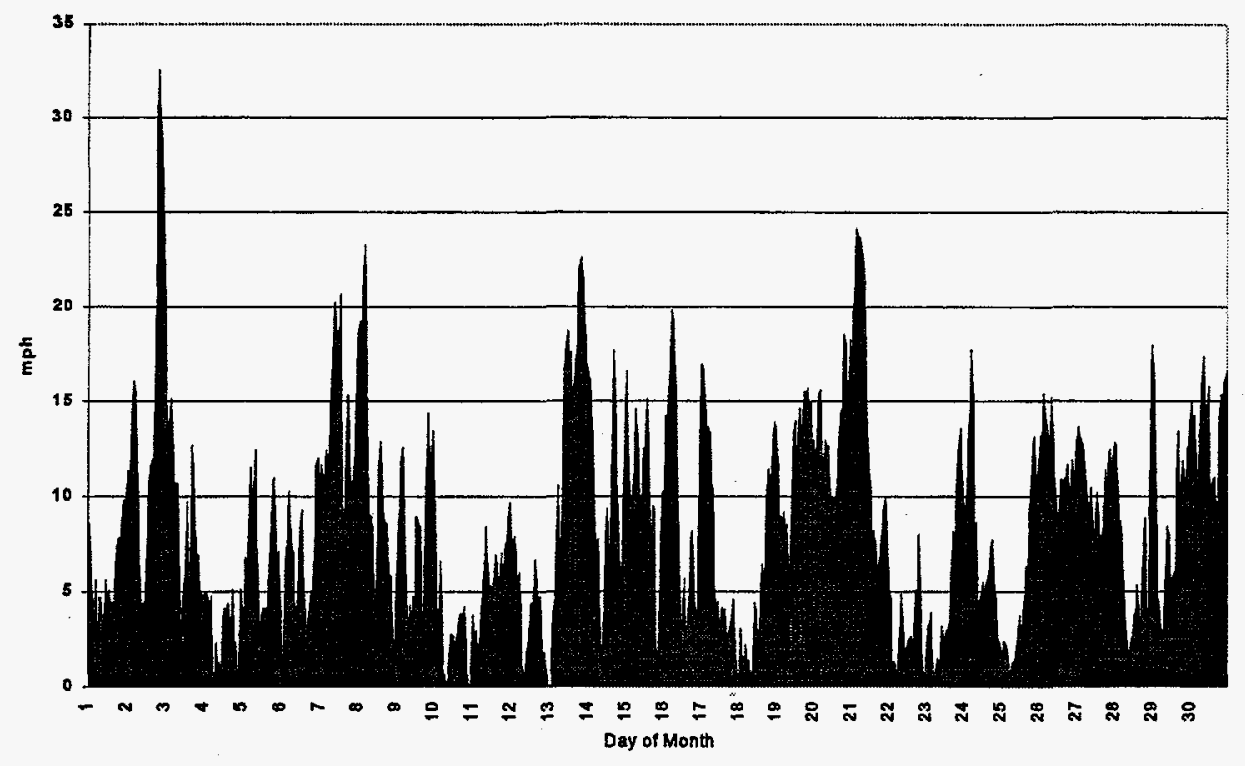

Fig. C.7. Hourly Mt. Constitution wind speed at 120-September 1994.

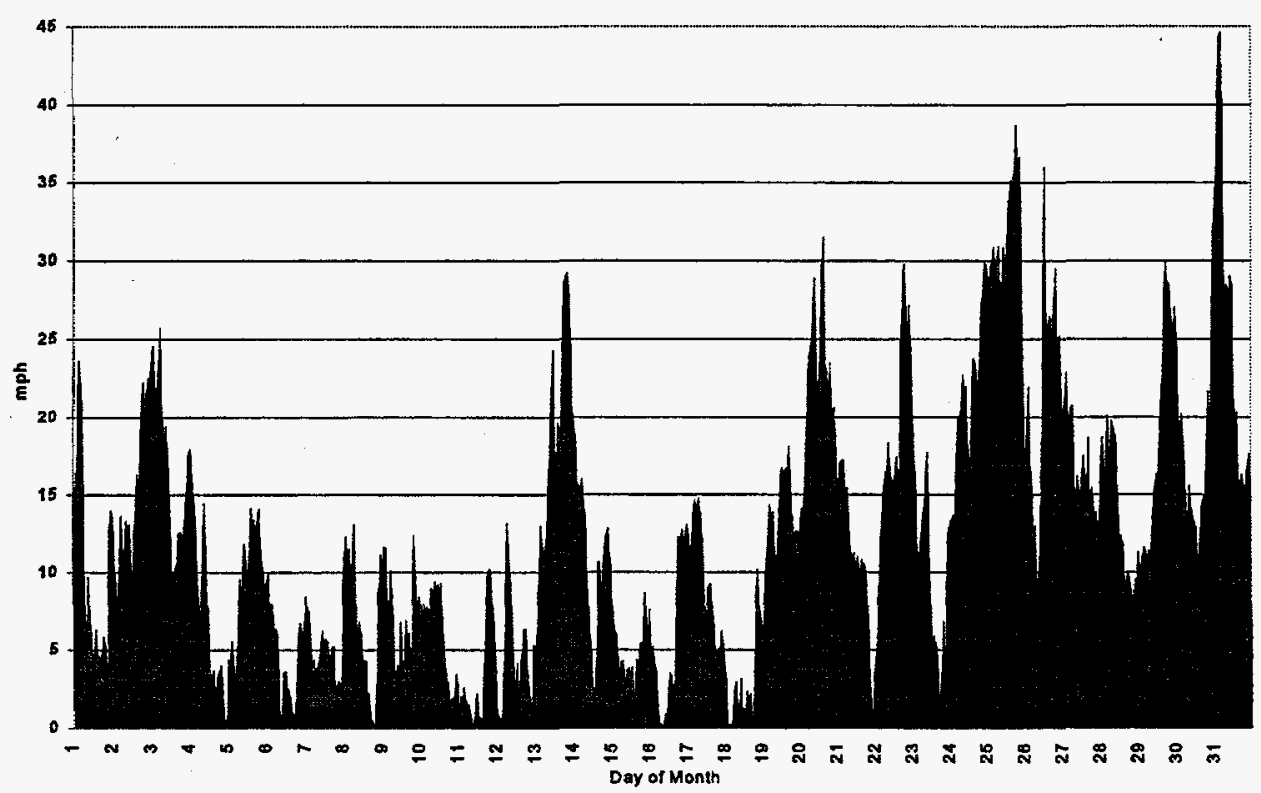

Fig. C.8. Hourly Mt. Constitution wind speed at 120'-October 1994. 


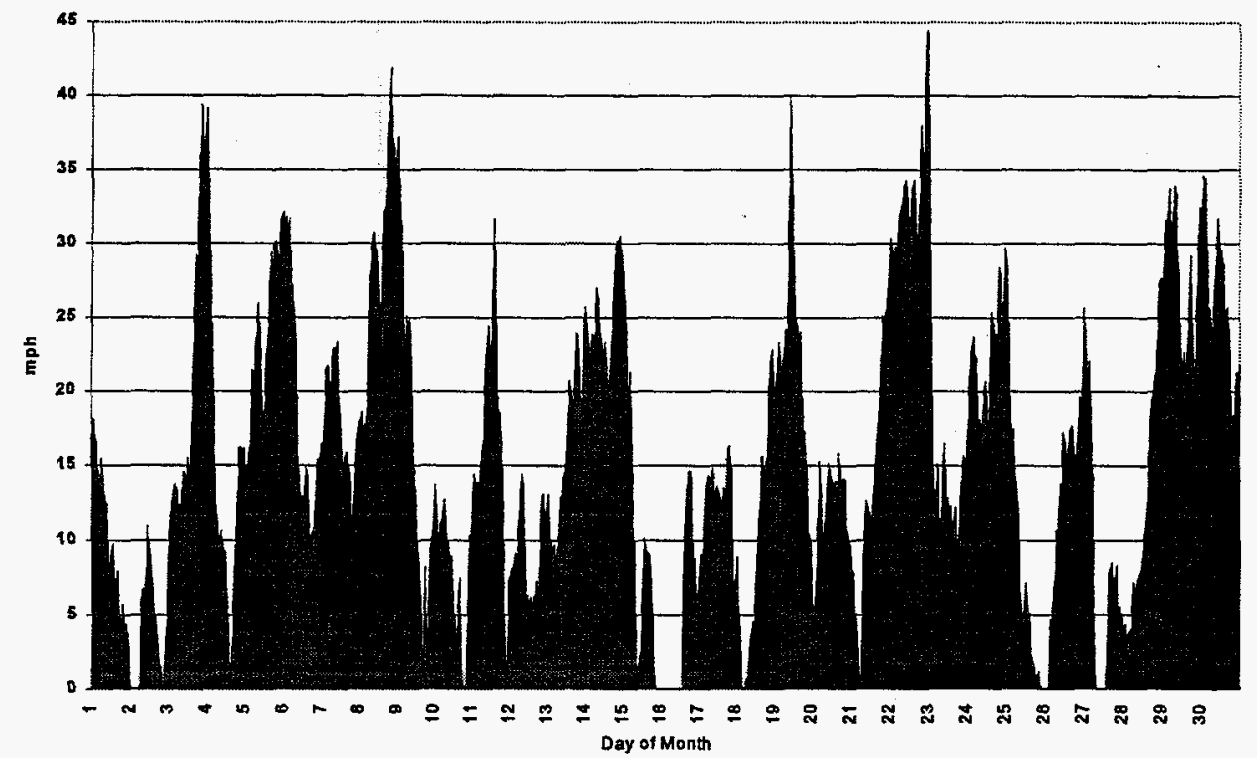

Fig. C.9. Hourly Mt. Constitution wind speed at 120-November 1994.

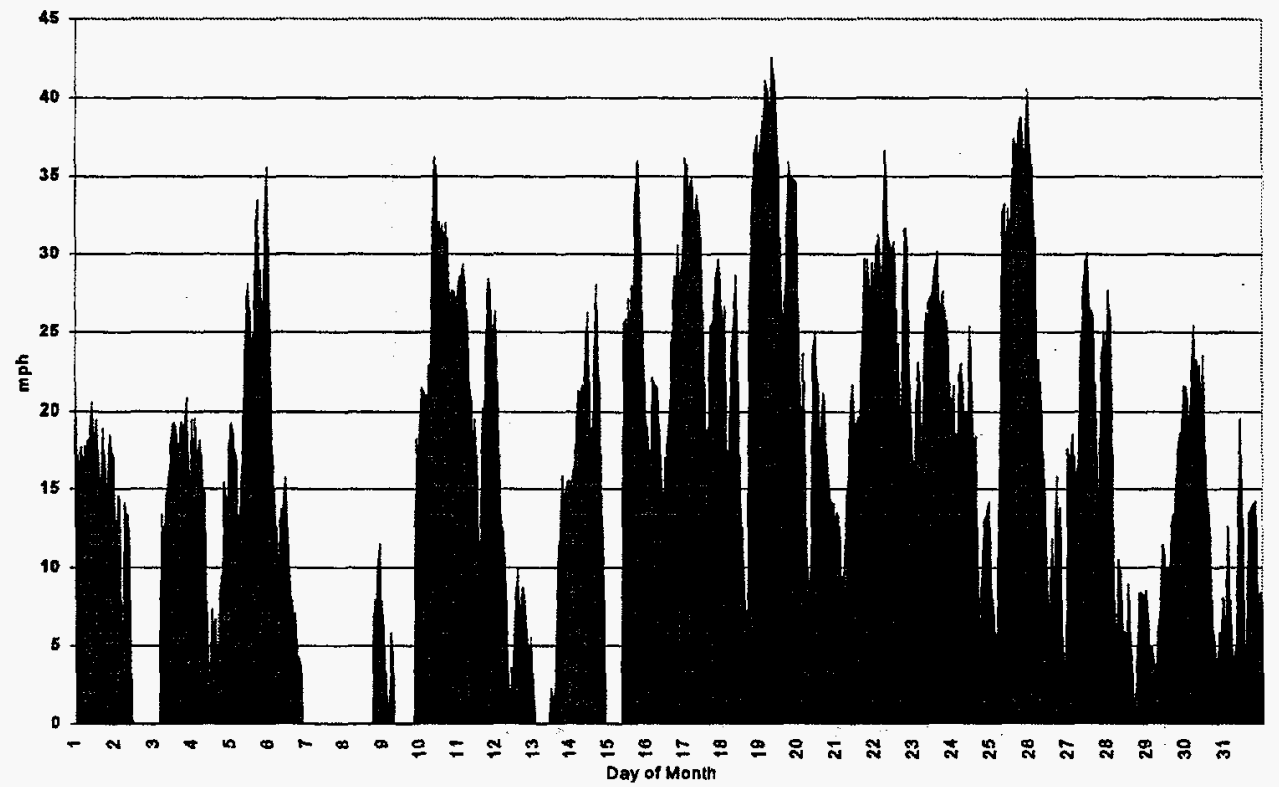

Fig. C.10. Hourly Mt. Constitution wind speed at 120'-December 1994. 


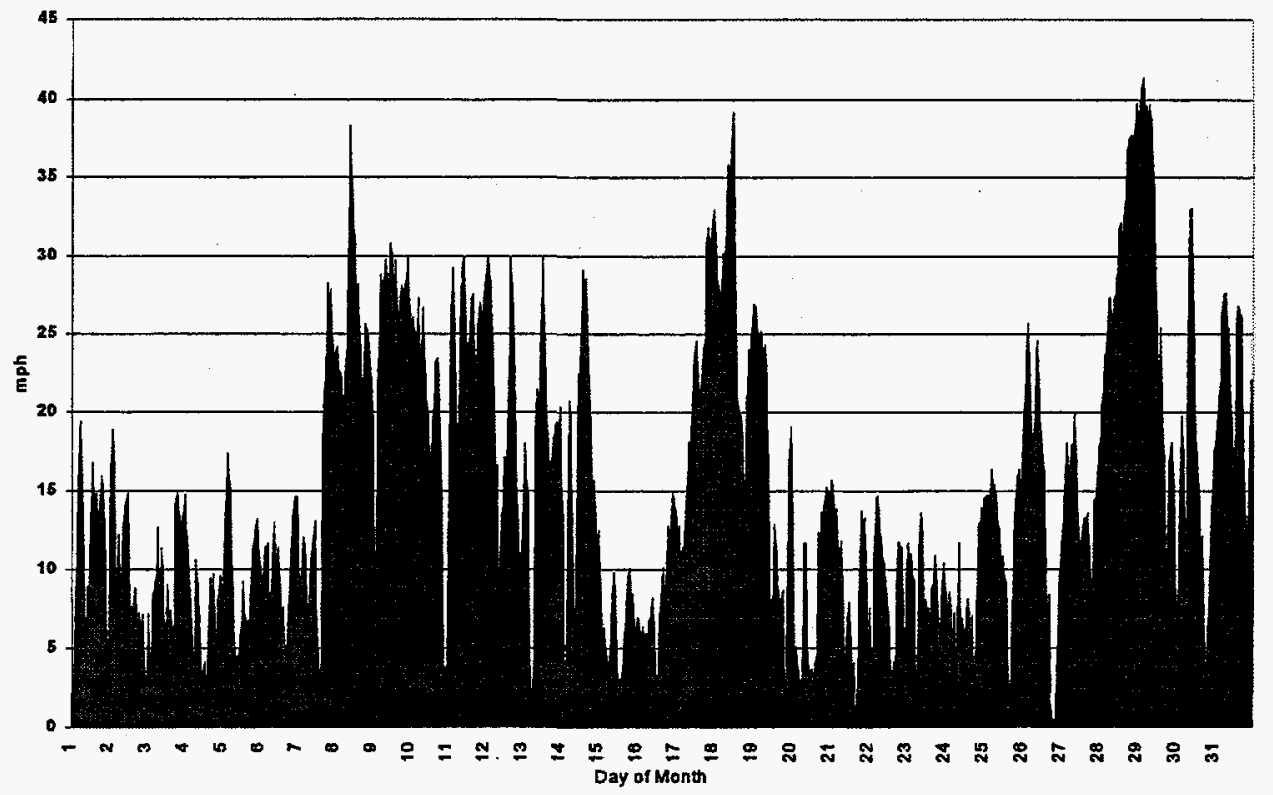

Fig. C.11. Hourly Mt. Constitution wind speed at 120'-January 1995.

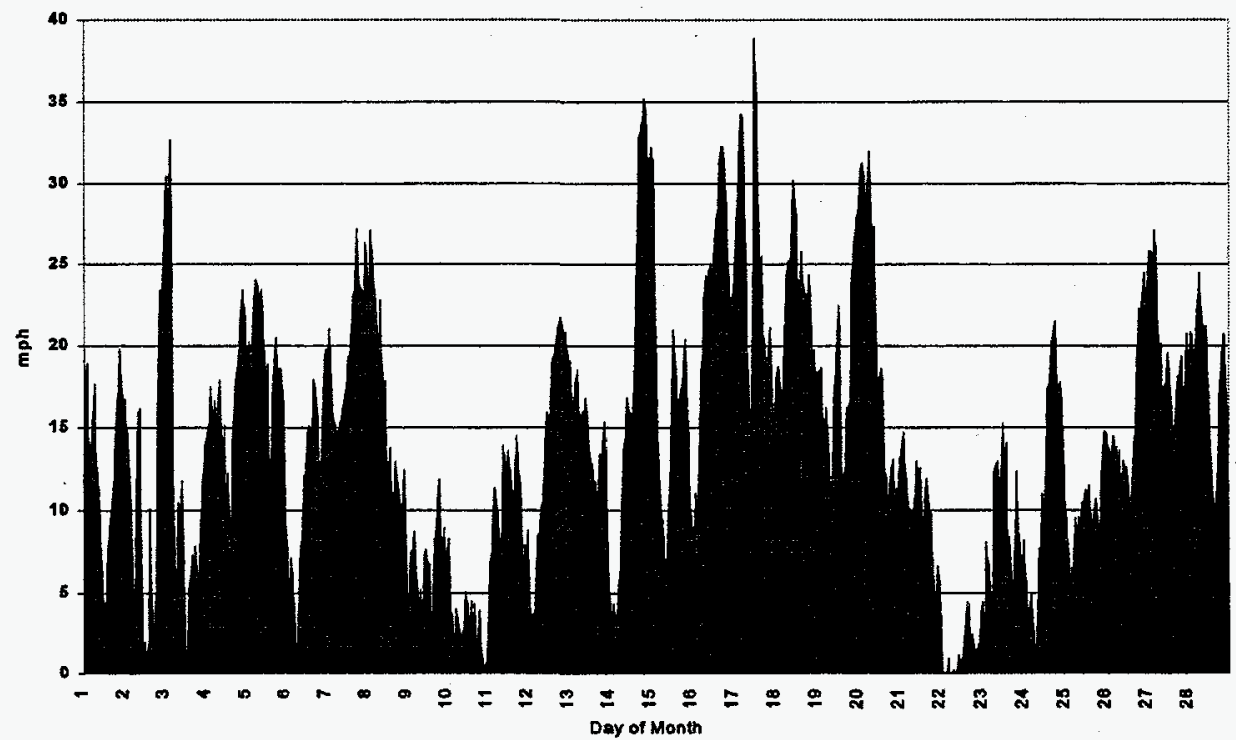

Fig. C.12. Hourly Mt. Constitution wind speed at 120'-February 1995. 


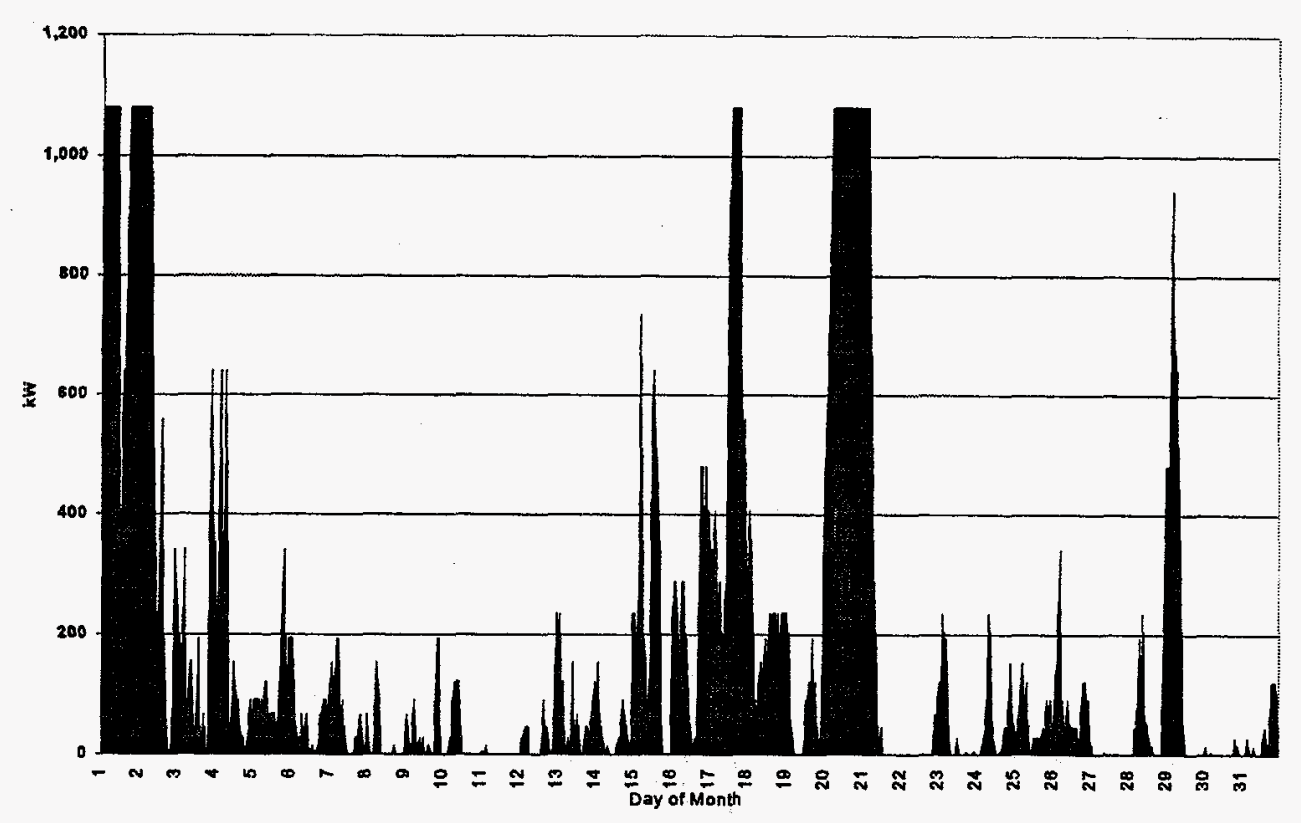

Fig. C.13. Hourly MW-scale wind plant performance: Mt. Constitution 120'-March 1994.

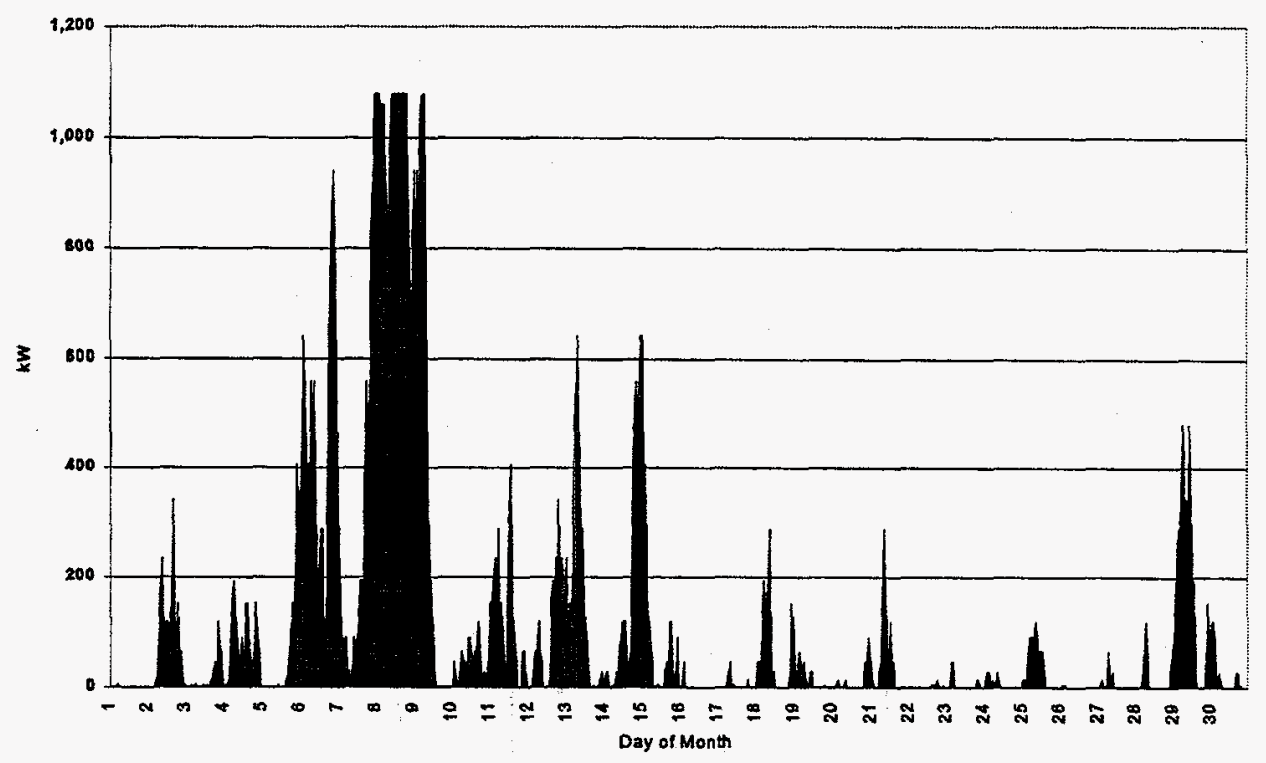

Fig. C.14. Hourly MW-scale wind plant performance: Mt. Constitution 120'-April 1994. 


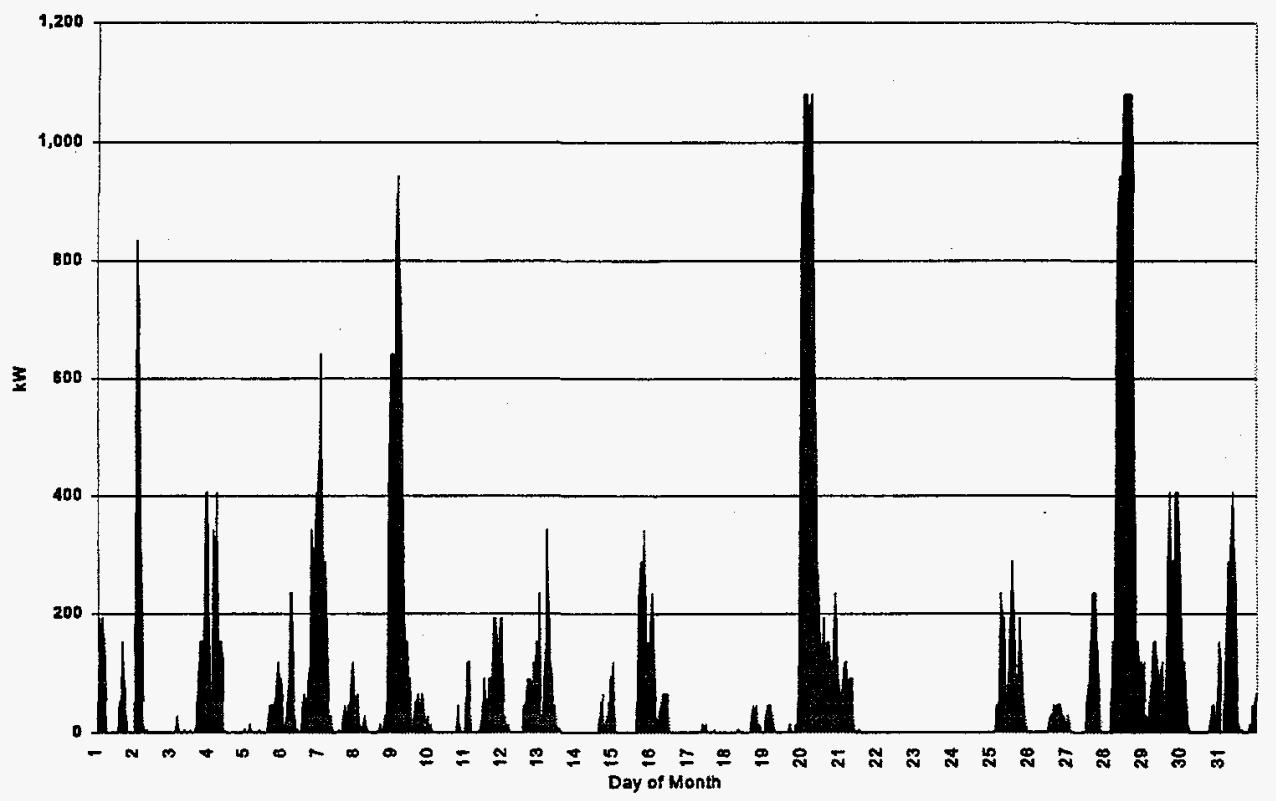

Fig. C.15. Hourly MW-scale wind plant performance: Mt. Constitution $120^{\prime}-$ May 1994.

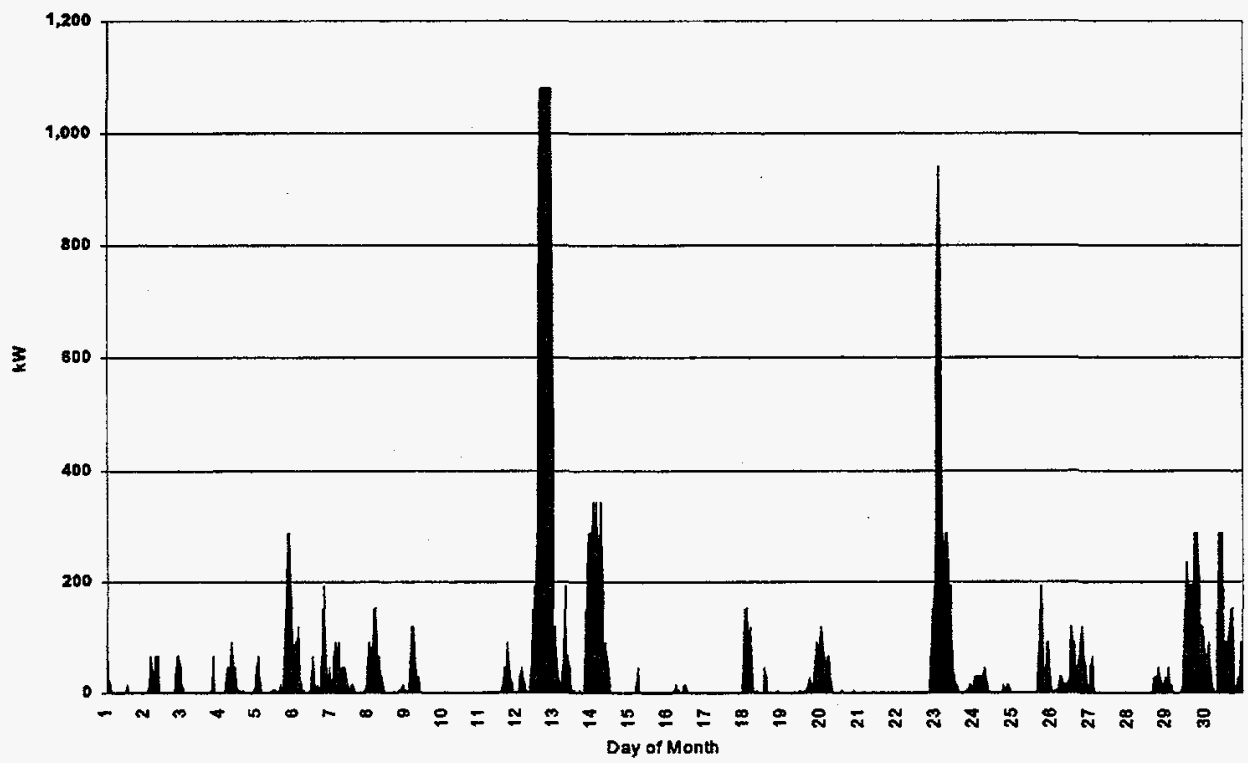

Fig. C.16. Hourly MW-scale wind plant performance: Mt. Constitution 120'_June 1994. 


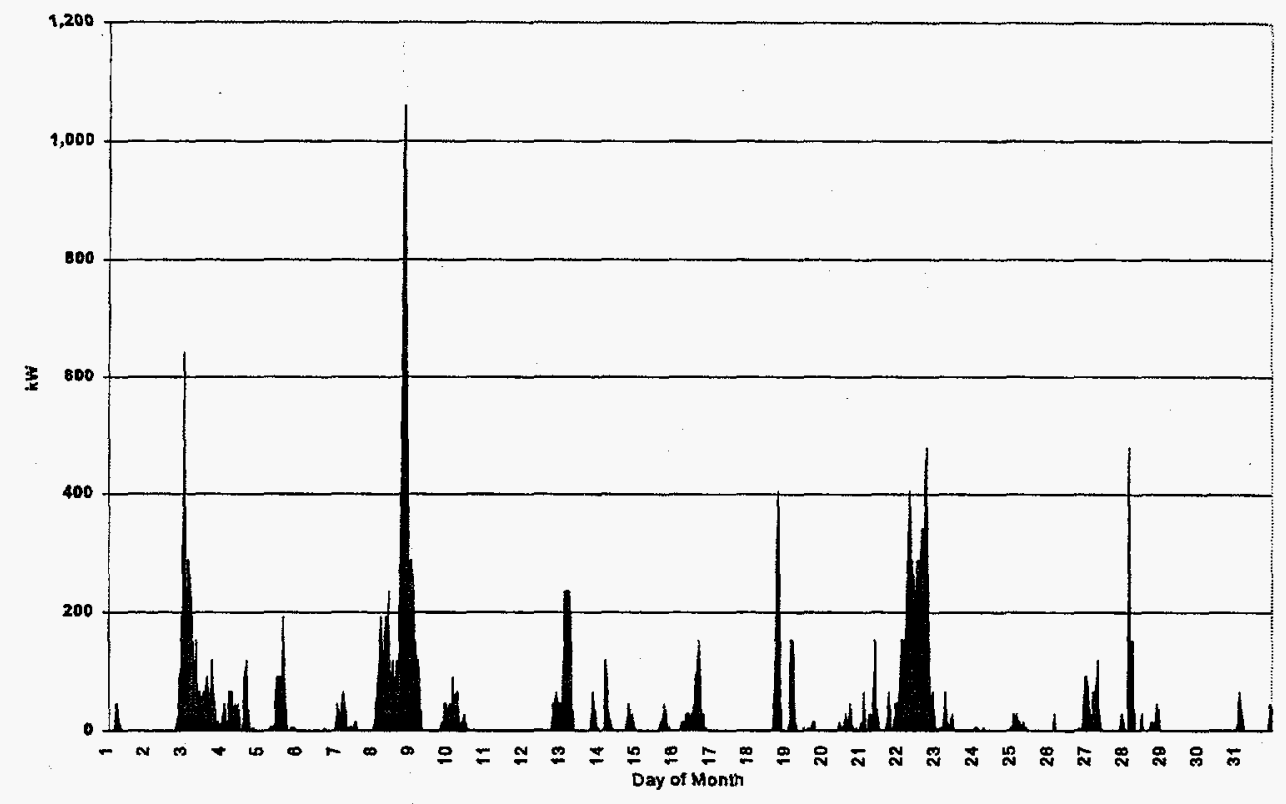

Fig. C.17. Hourly MW-scale wind plant performance: Mt. Constitution 120 - July 1994.

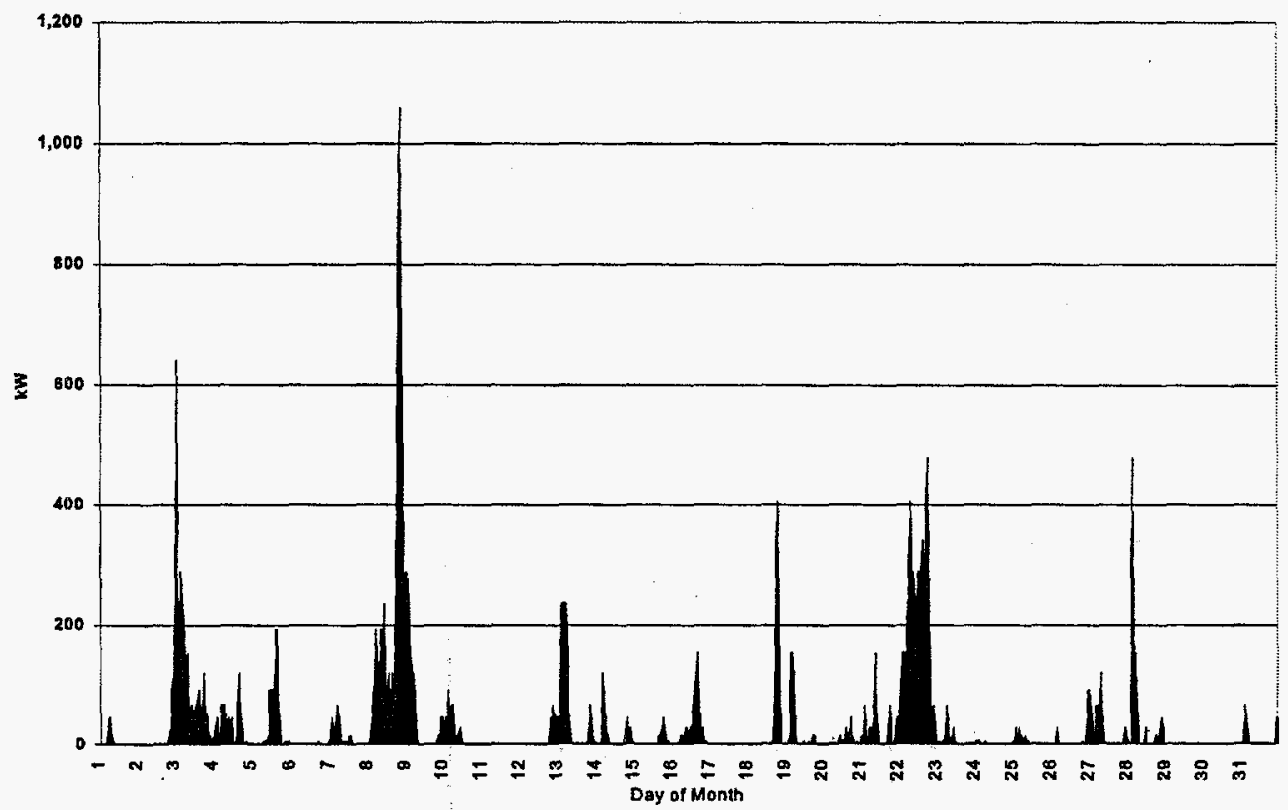

Fig. C.18. Hourly MW-scale wind plant performance: Mt. Constitution 120'-August 1994. 


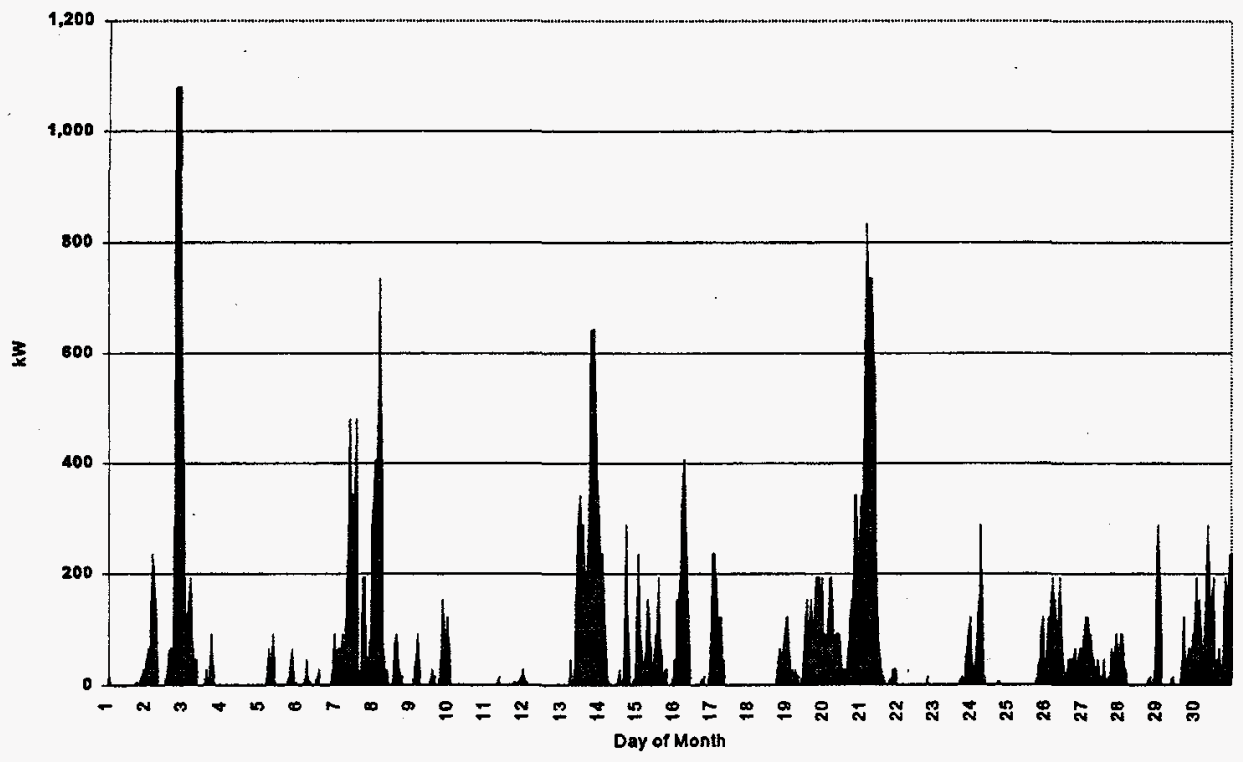

Fig. C.19. Hourly MW-scale wind plant performance: Mt. Constitution 120'-September 1994.

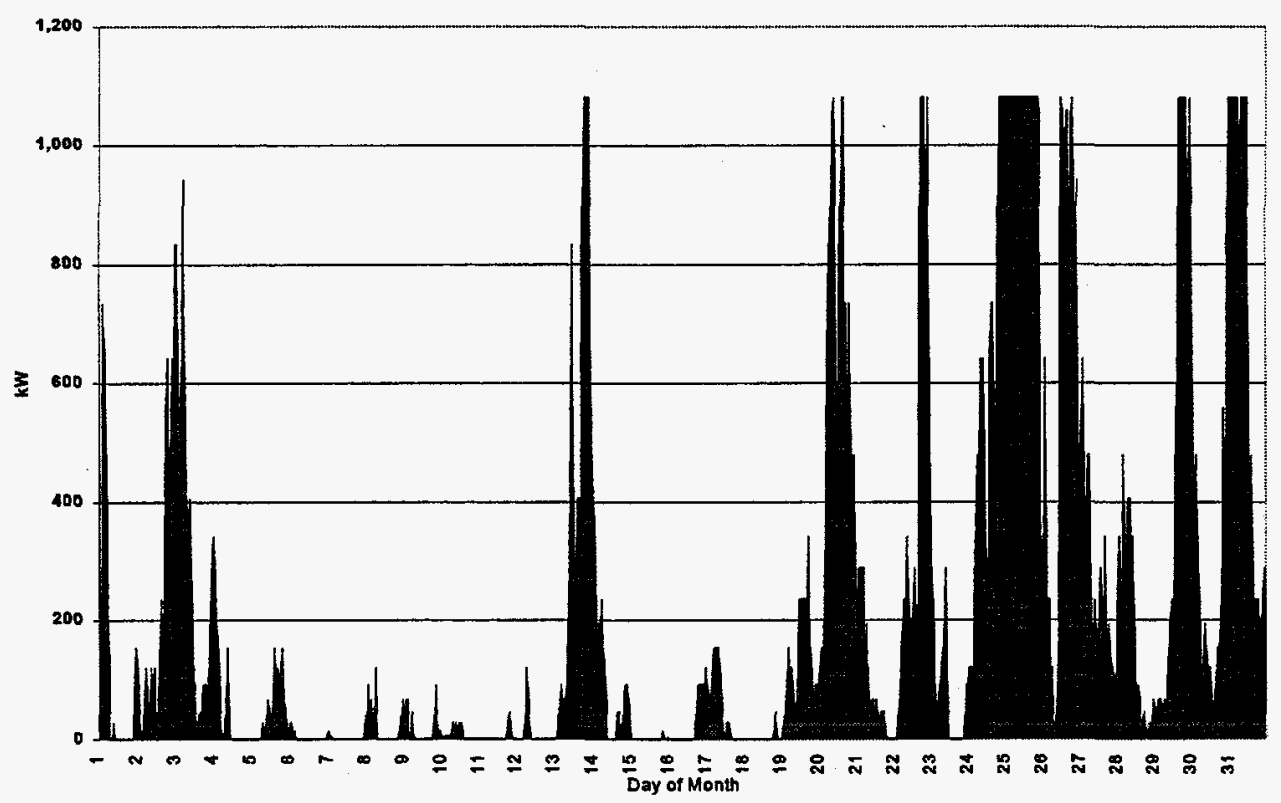

Fig. C.20. Hourly MW-scale wind plant performance: Mt. Constitution 120'-October 1994. 


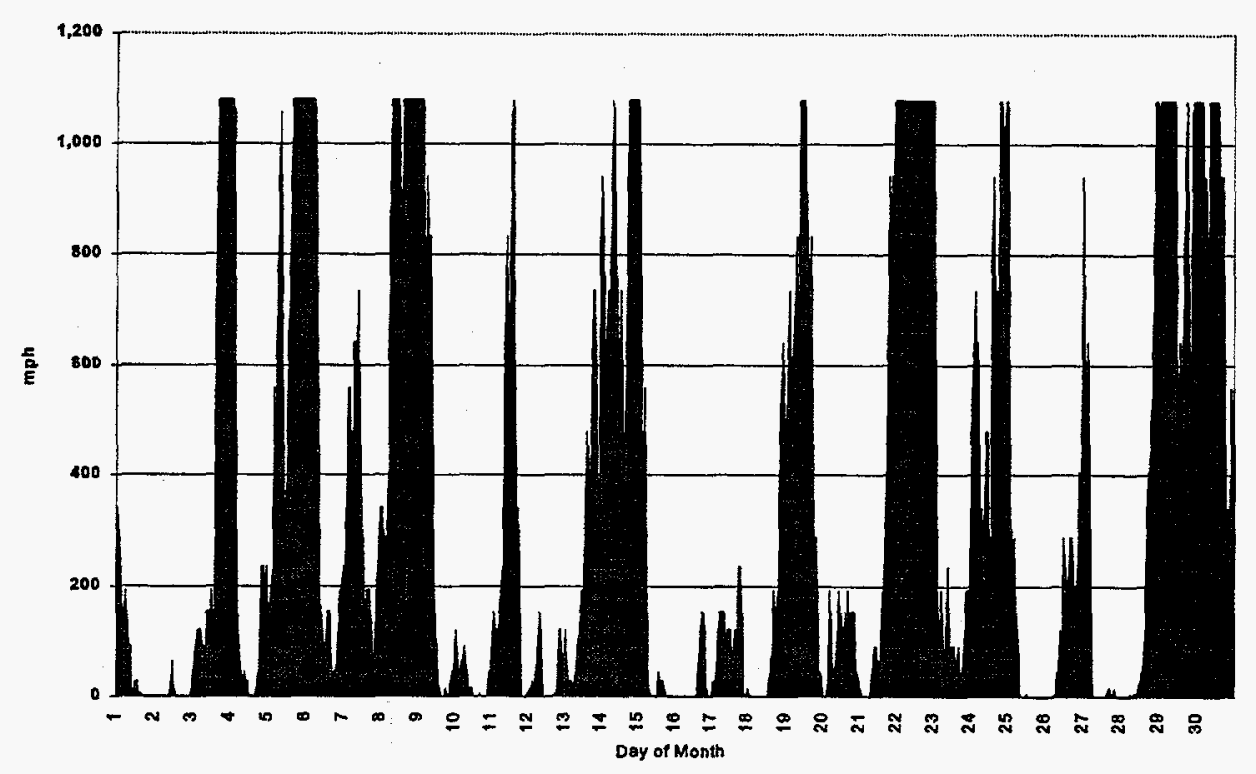

Fig. C.21. Hourly MW-scale wind plant performance: Mt. Constitution 120'-November 1994.

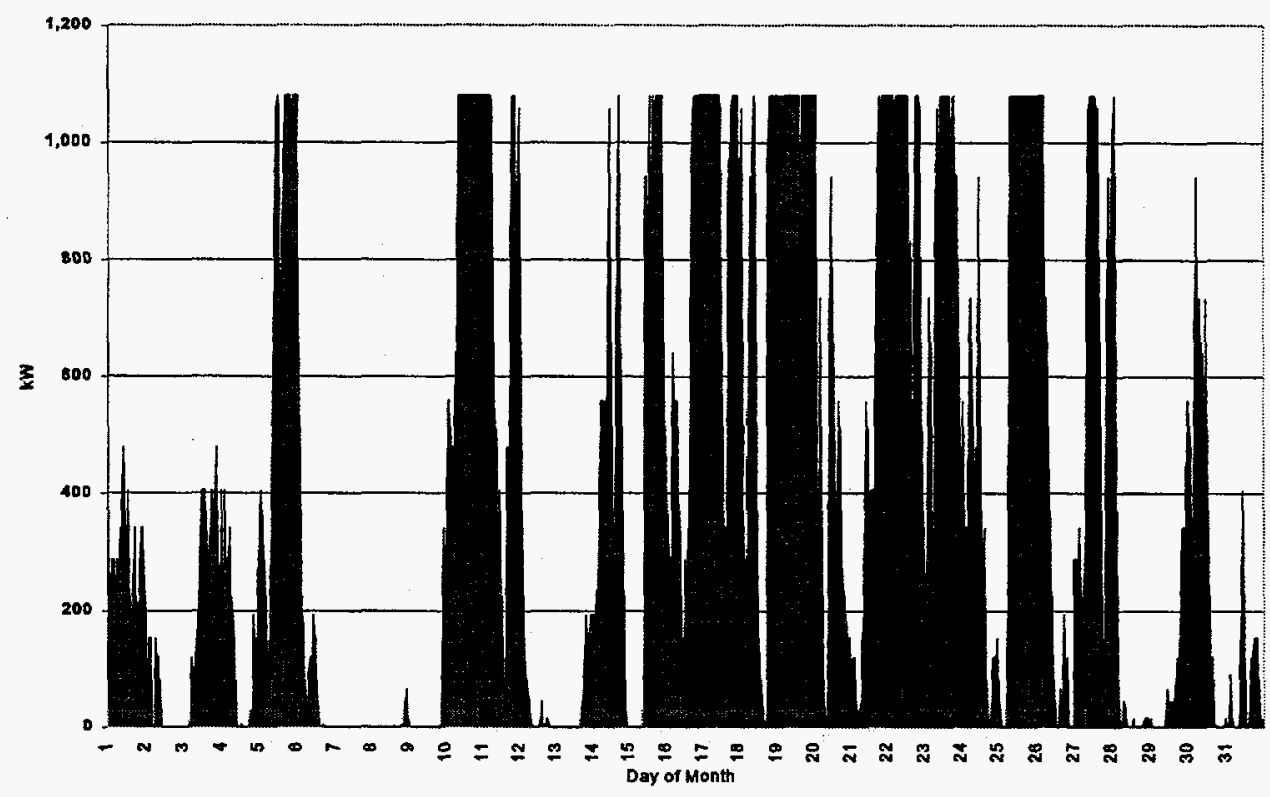

Fig. C.22. Hourly MW-scale wind plant performance: Mt. Constitution 120'December 1994. 


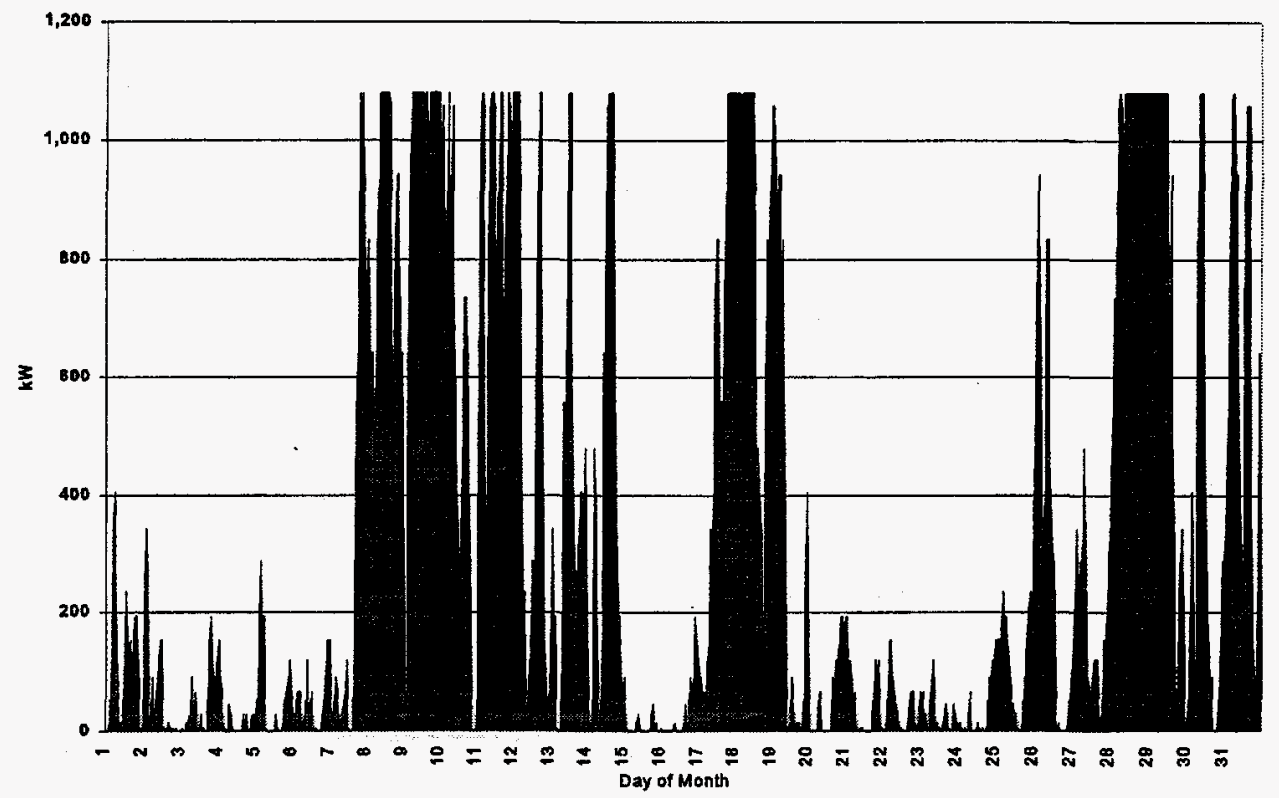

Fig. C.23. Hourly MW-scale wind plant performance: Mt. Constitution 120'-January 1995.

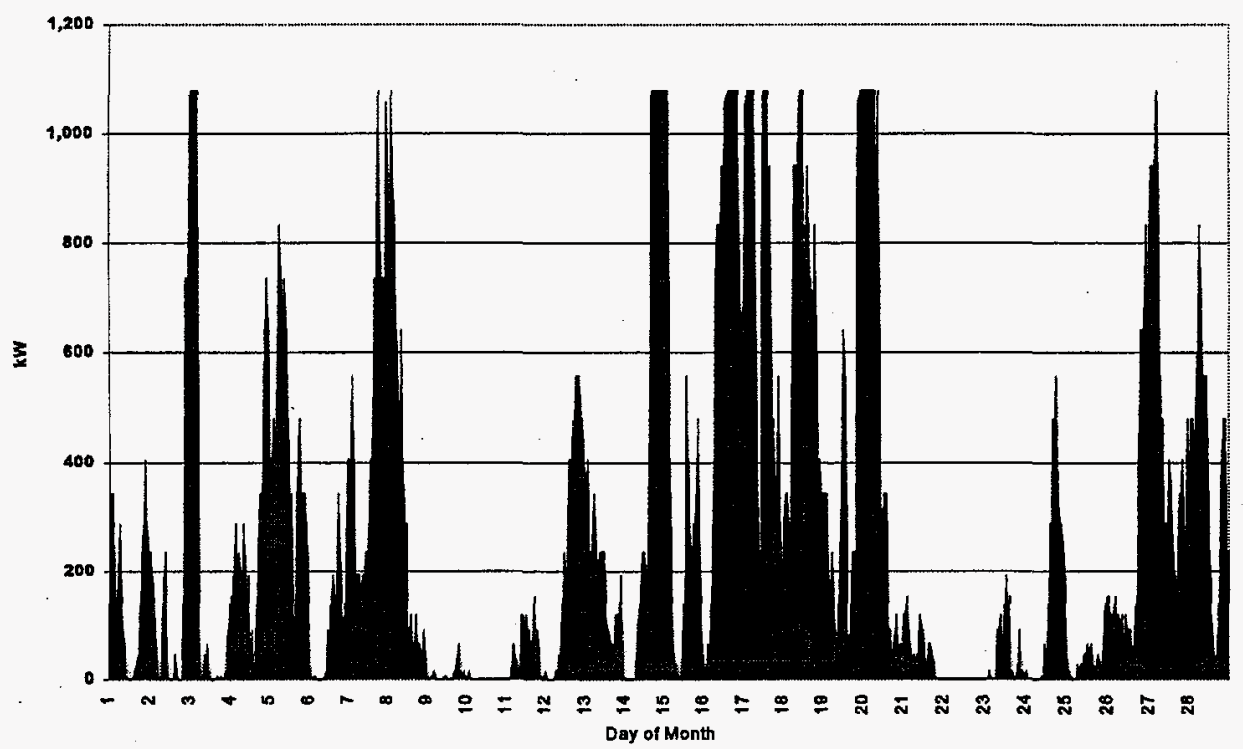

Fig. C.24. Hourly MW-scale wind plant performance: Mt. Constitution 120 - February 1995. 


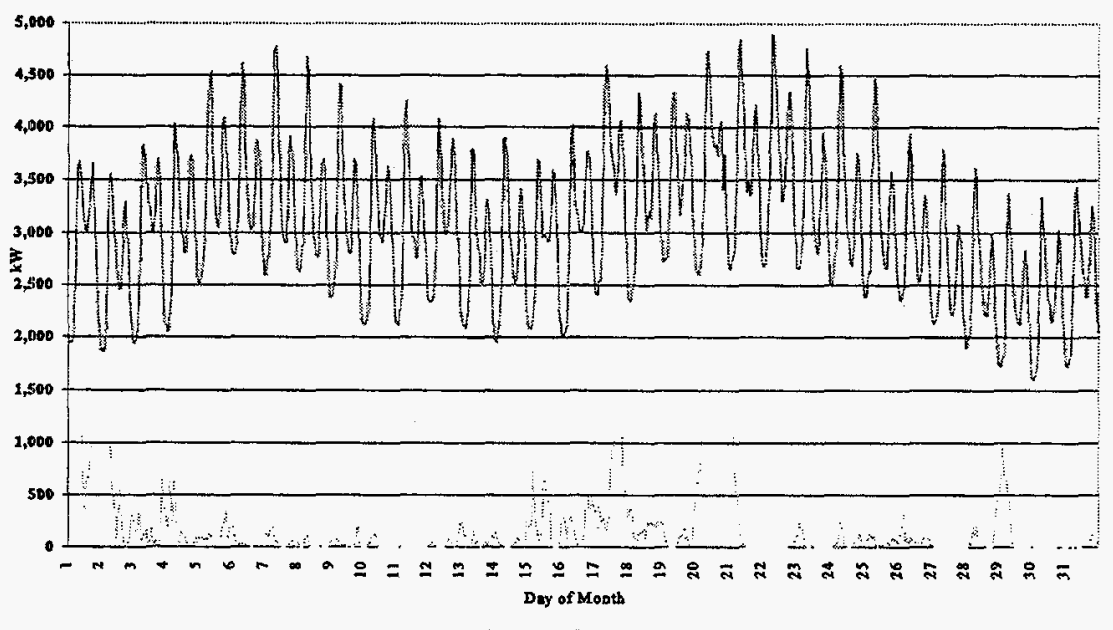

Losd WT Ootpute

Fig. C.25. Correlation between Eastsound load and MW-scale wind farm performance: Mt. Constitution 120' -March 1994.

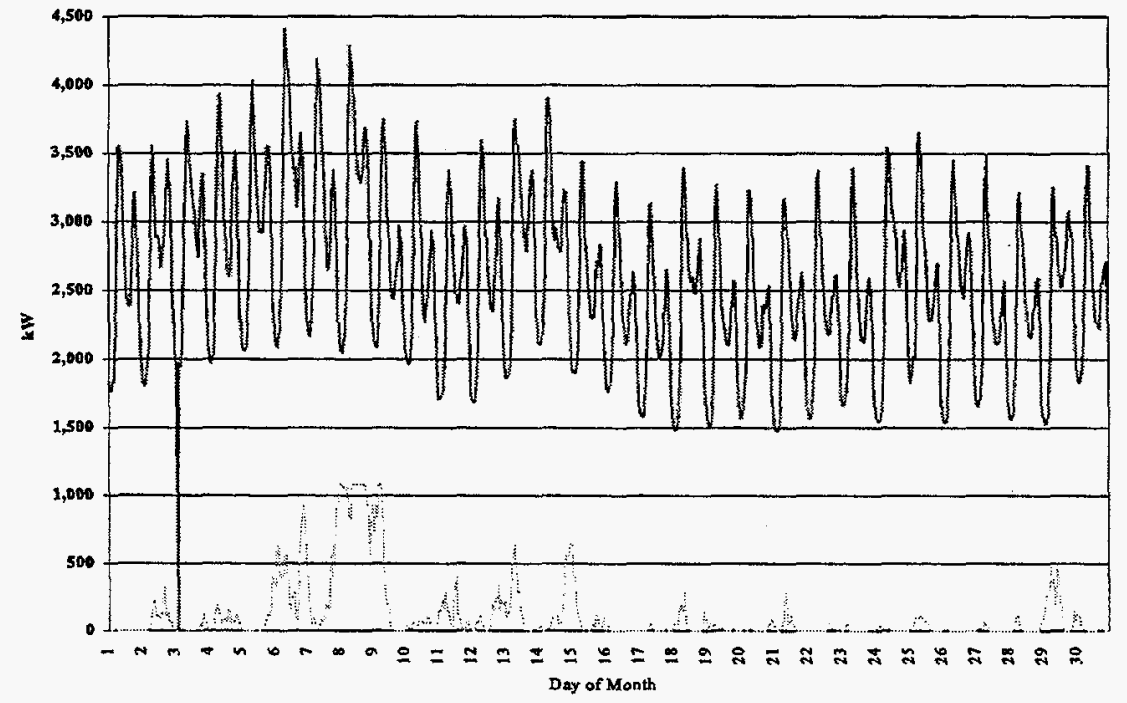

Iond …..... Wr Oatpat

Fig. C.26. Correlation between Eastsound load and MW-scale wind farm performance: Mt. Constitution 120' -April 1994. 


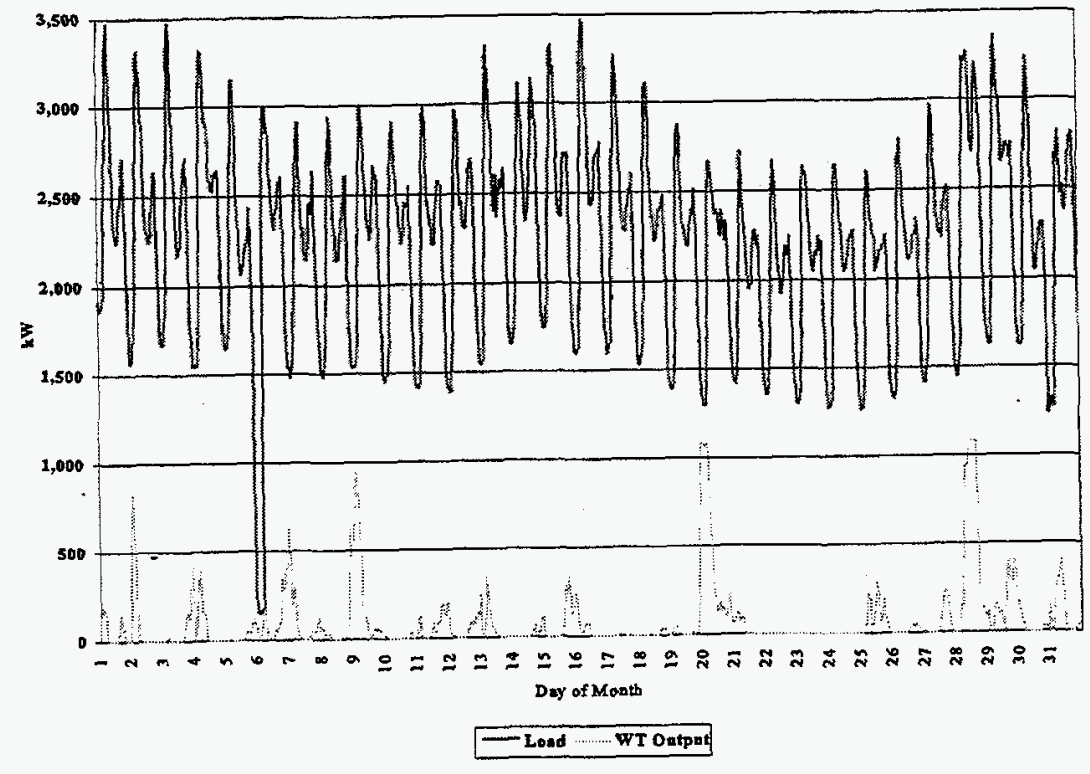

Fig. C.27. Correlation between Eastsound load and MW-scale wind farm performance: Mt. Constitution 120' -May 1994.

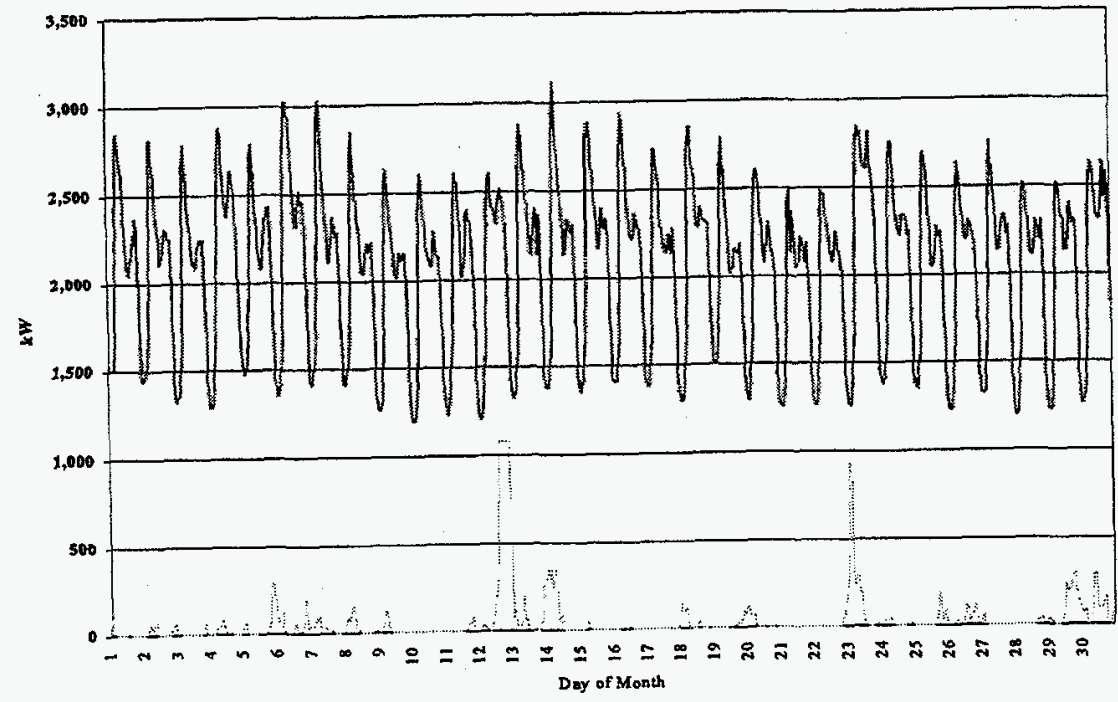

Loud …....... WT Ontput

Fig. C.28. Correlation between Eastsound load and MW-scale wind farm performance: Mt. Constitution 120' -June 1994. 


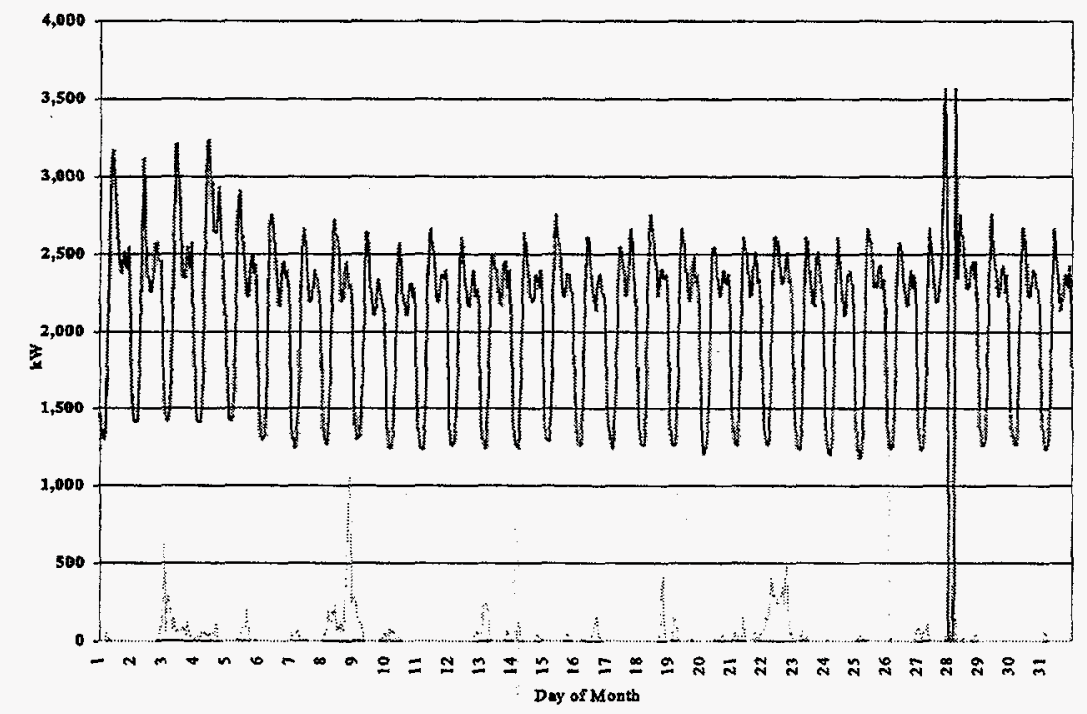

Load …… WT Ortpat

Fig. C.29. Correlation between Eastsound load and MW-scale wind farm performance: Mt. Constitution 120' -July 1994.

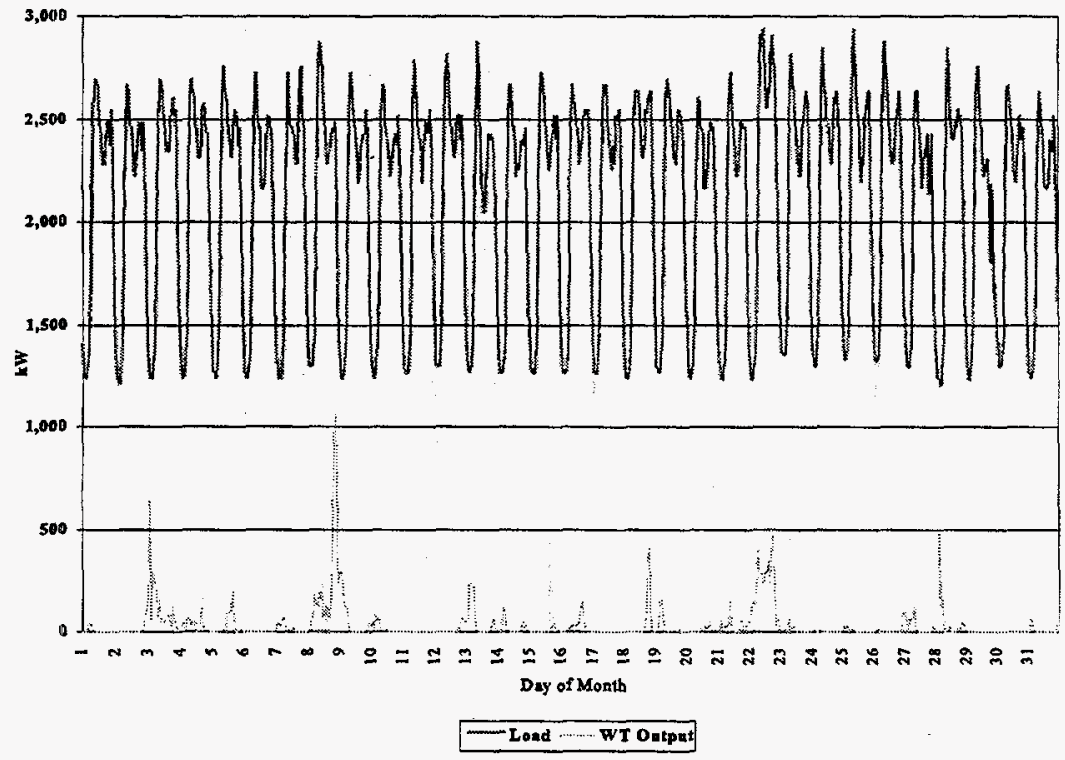

Fig. C.30. Correlation between Eastsound load and MW-scale wind farm performance: Mt. Constitution 120' -August 1994. 


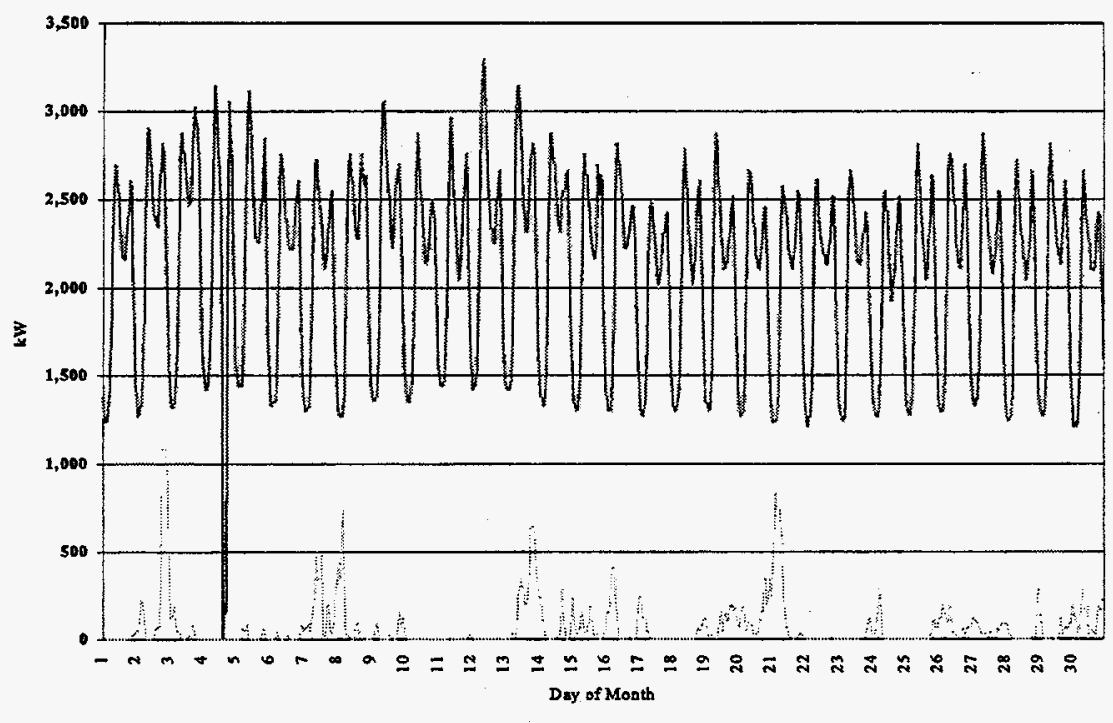

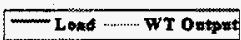

Fig. C.31. Correlation between Eastsound load and MW-scale wind farm performance: Mt. Constitution 120' -September 1994.

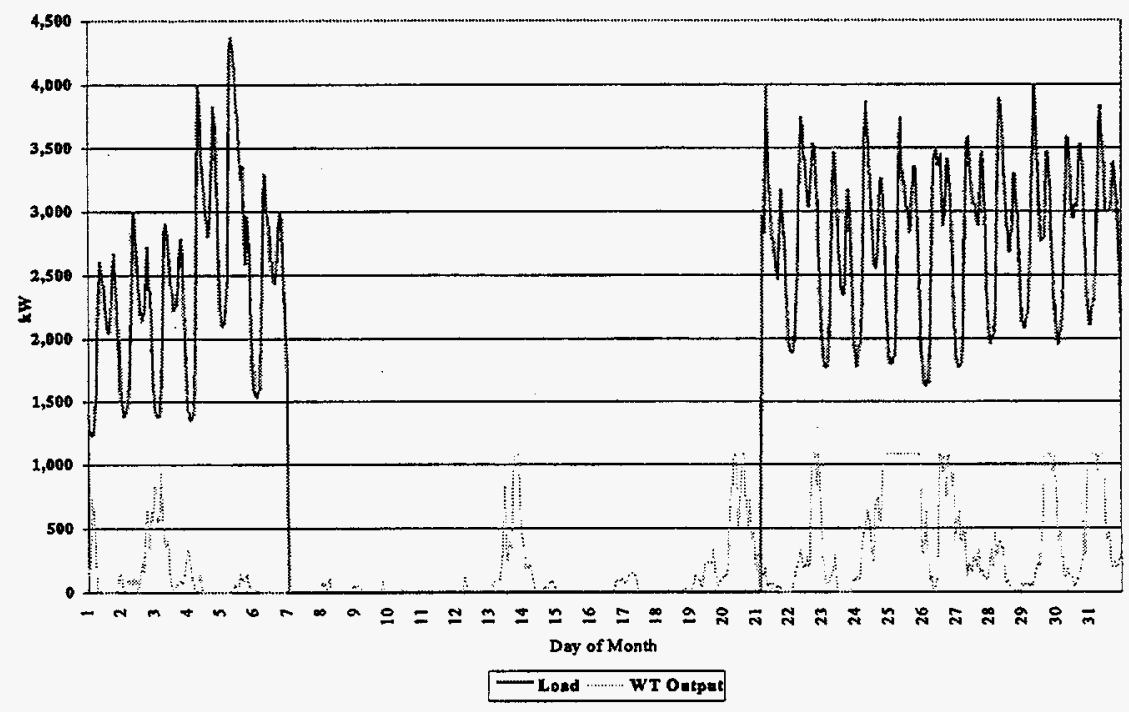

Fig. C.32. Correlation between Eastsound load and MW-scale wind farm performance: Mt. Constitution 120' -October 1994. 


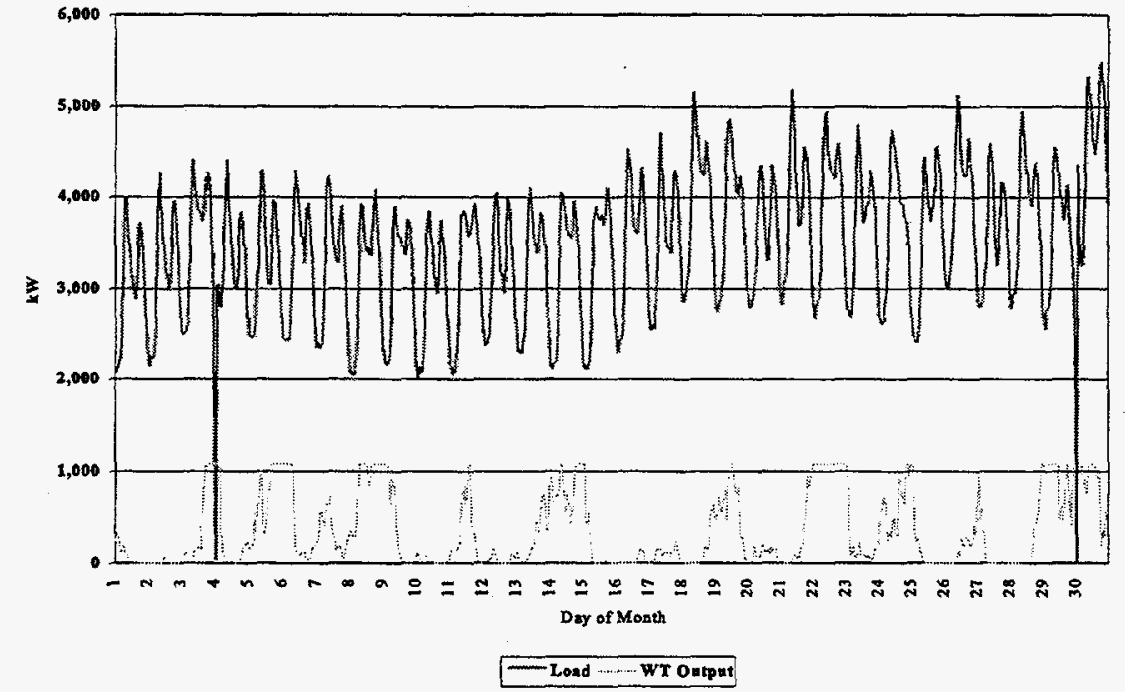

Fig. C.33. Correlation between Eastsound load and MW-scale wind farm performance: Mt. Constitution 120' -November 1994.

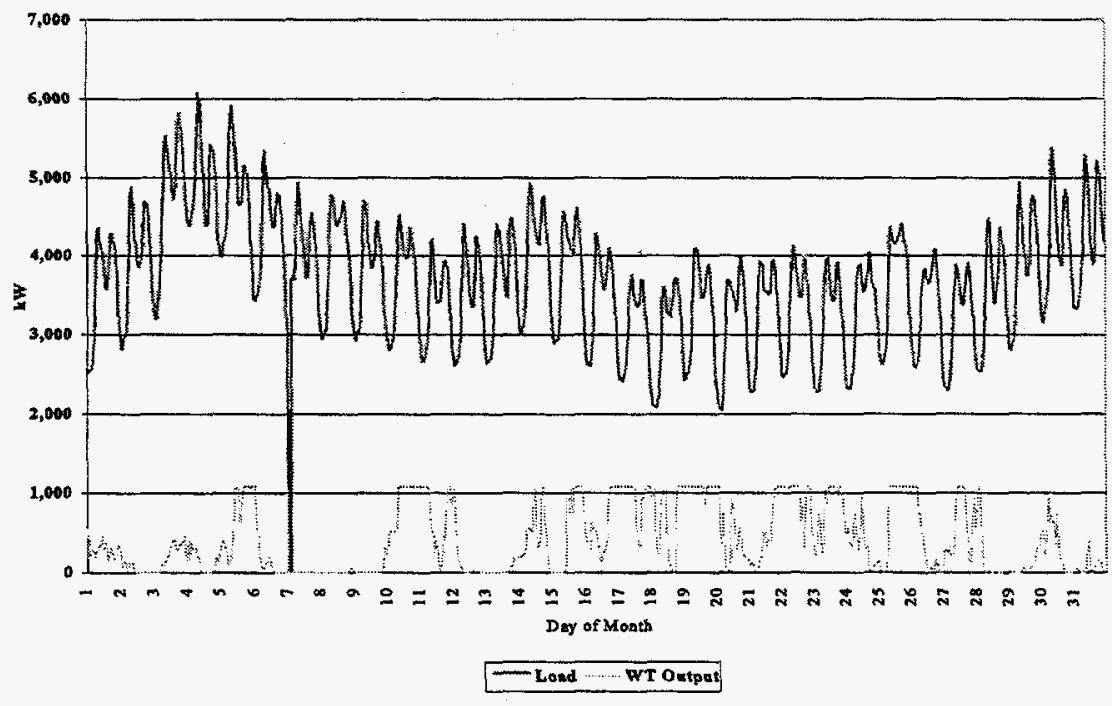

Fig. C.34. Correlation between Eastsound load and MW-scale wind farm performance: Mt. Constitution 120' -December 1994. 


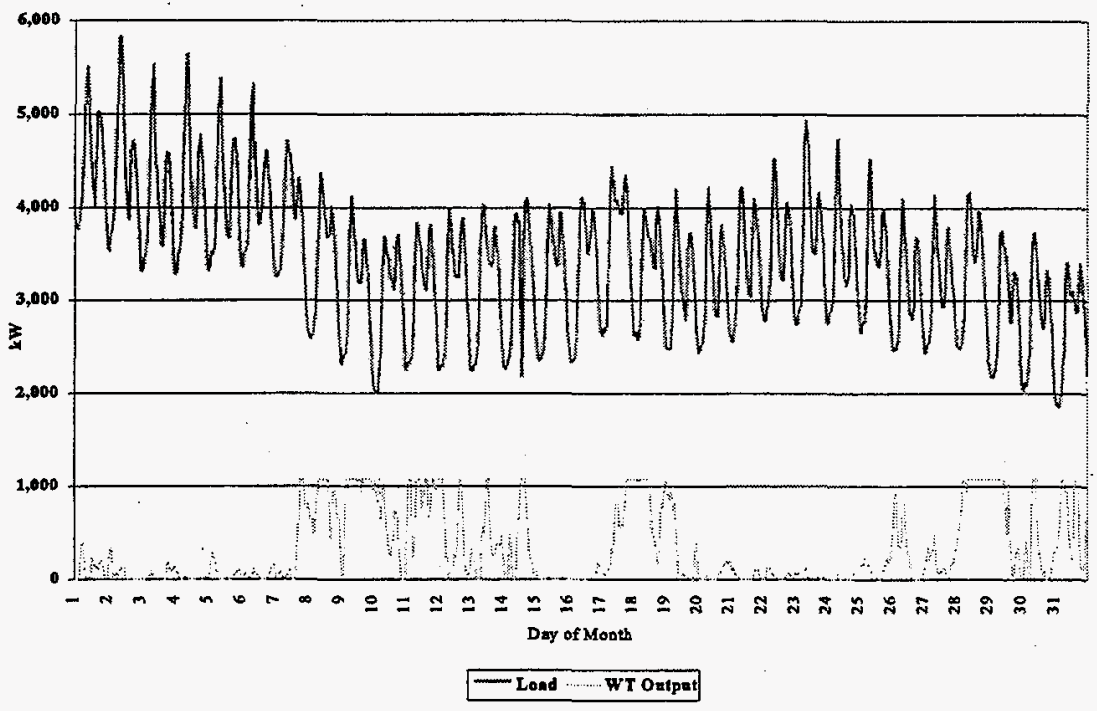

Fig. C.35. Correlation between Eastsound load and MW-scale wind farm performance: Mt. Constitution 120' -January 1995.

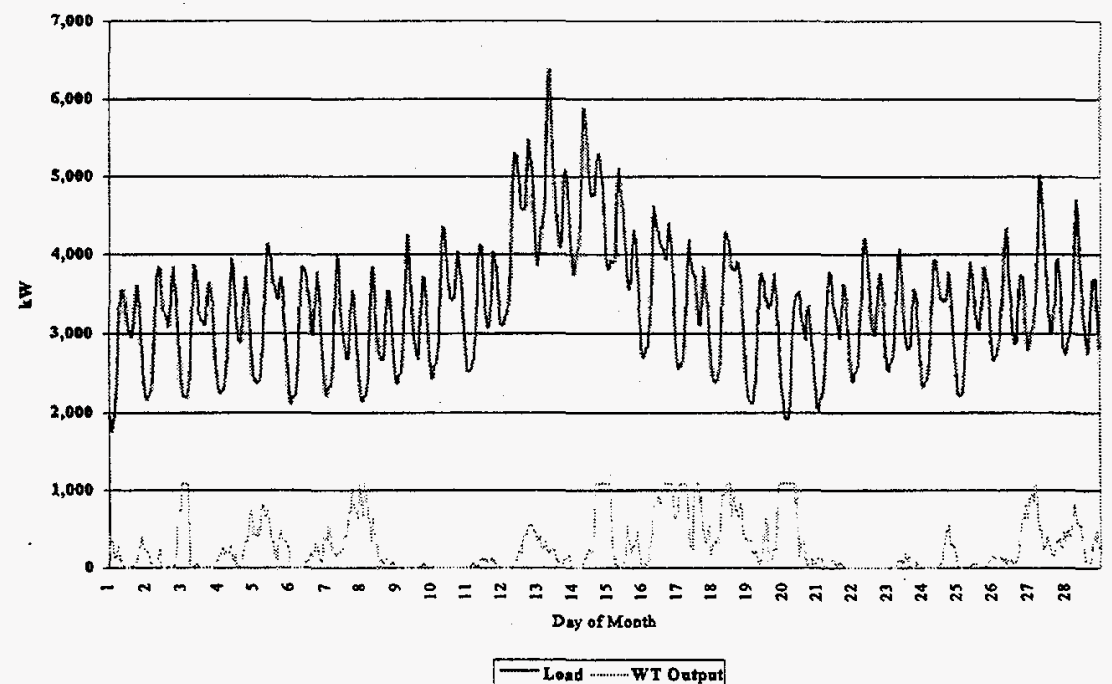

Fig. C.36. Correlation between Eastsound load and MW-scale wind farm performance: Mt. Constitution 120' -February 1995. 


\section{APPENDIX D}

\section{HOURLY WIND AND MW-SCALE WIND PLANT PERFORMANCE- OPALCO 133'}

Hourly wind data were also collected at the OPALCO office at 133' and at 95' above the ground beginning on March 5, 1994. Figures D.1 through D.12 present the hourly winds monthly from March 1994 through February 1995' at the 133' level. Wind data for August 1994 were lost. For this study, hourly wind data for July 1994 (Figure D.5) were also assumed for August 1994 (Figure D.6).

Resulting hourly MW-scale wind plant performance are presented in Figures D.13 through D.24 for March 1994 through February 1995 assuming the above wind data, three 350 $\mathrm{kW}$ variable speed wind turbines, and the wind-power curve presented in Figure 3.1.

Figures D.25 through D.36 illustrate the resulting hourly correlation of a MW-scale wind plant output with the hourly Eastsound loads from March 1994 through February 1995. 


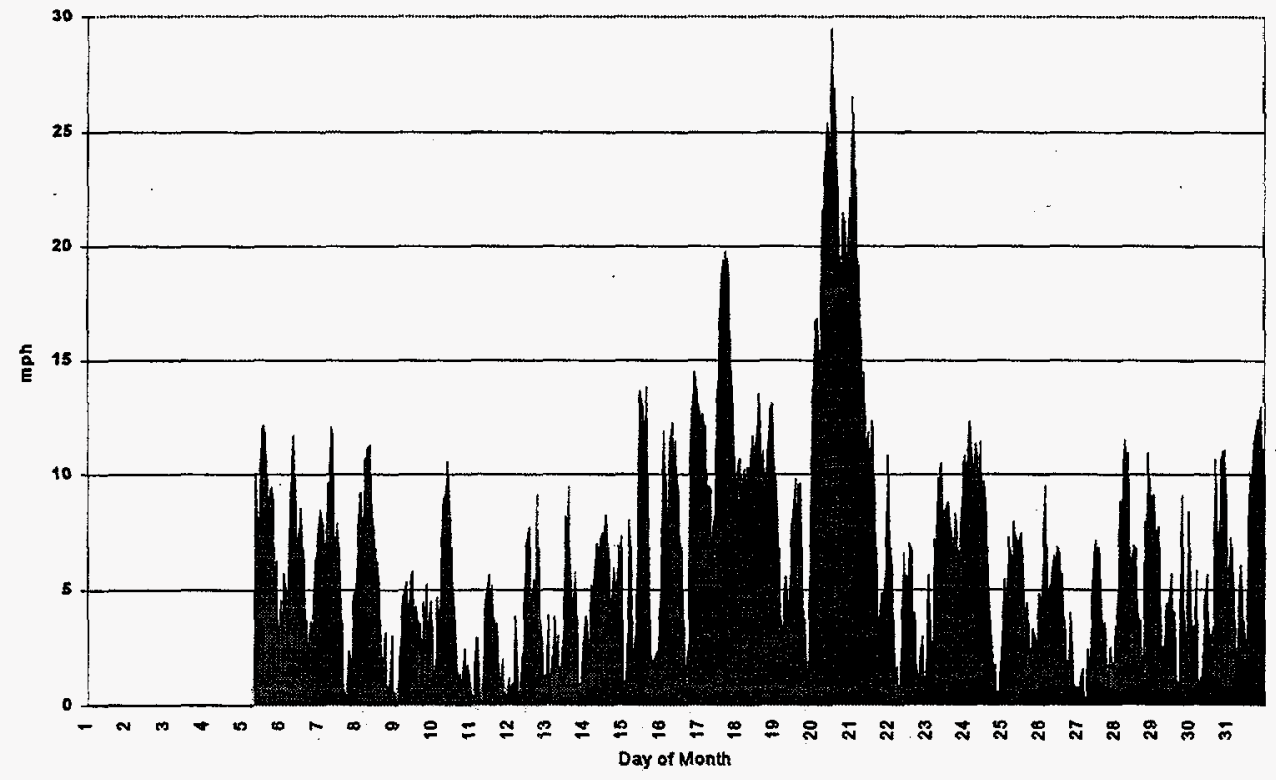

Fig. D.1. Hourly OPALCO wind speed at 133'-March 1994.

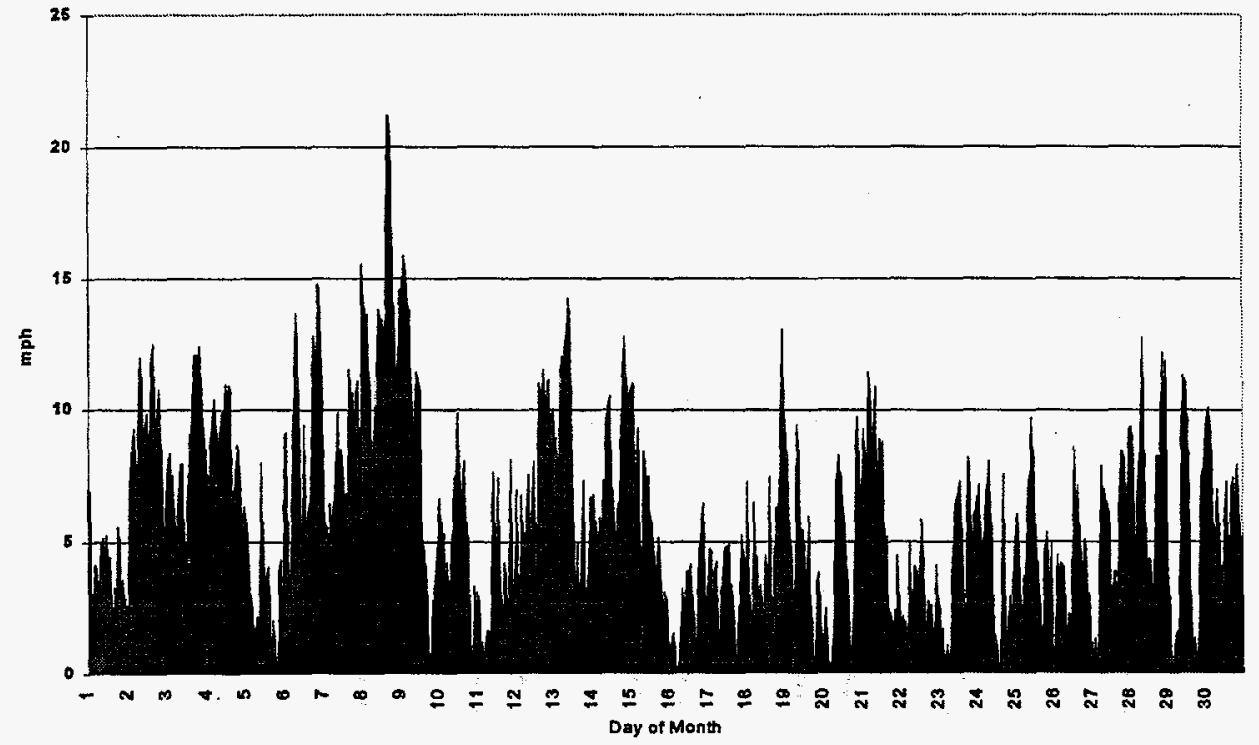

Fig. D.2. Hourly OPALCO wind speed at 133'-April 1994.

D-2 


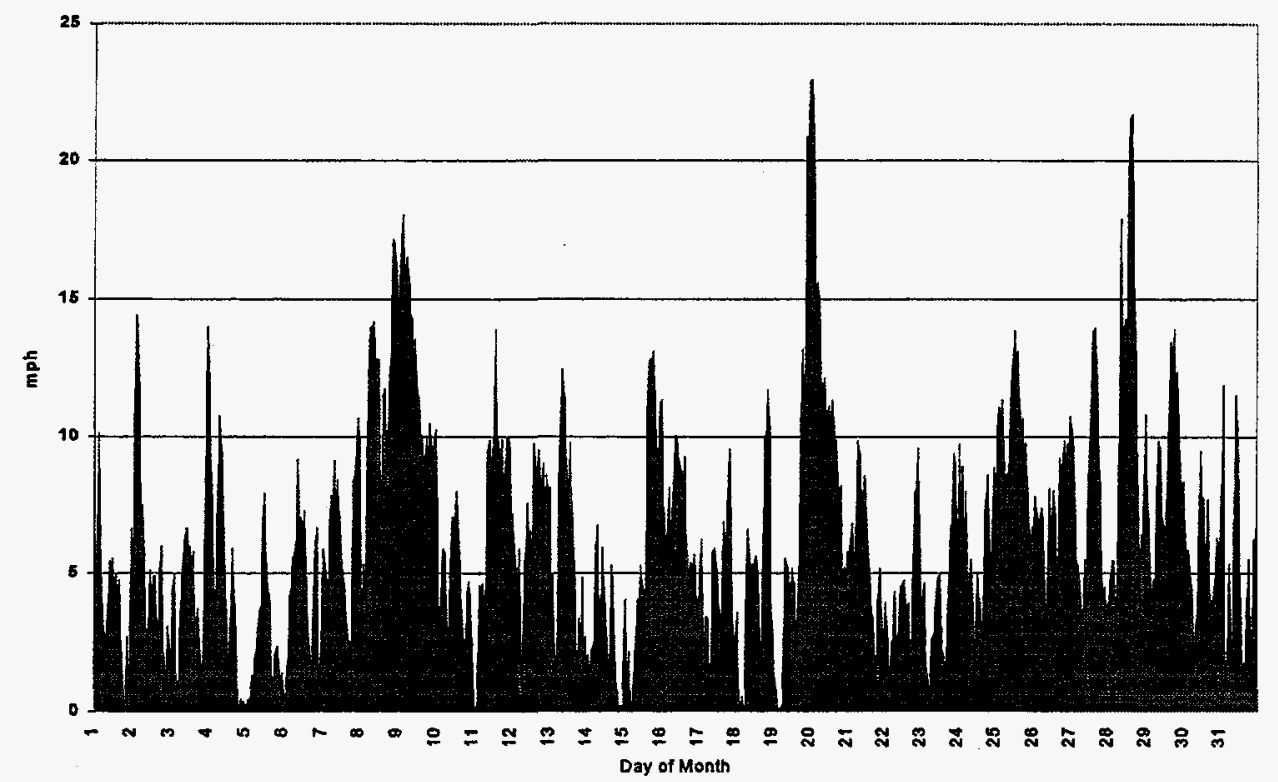

Fig. D.3. Hourly OPALCO wind speed at 133'-May 1994.

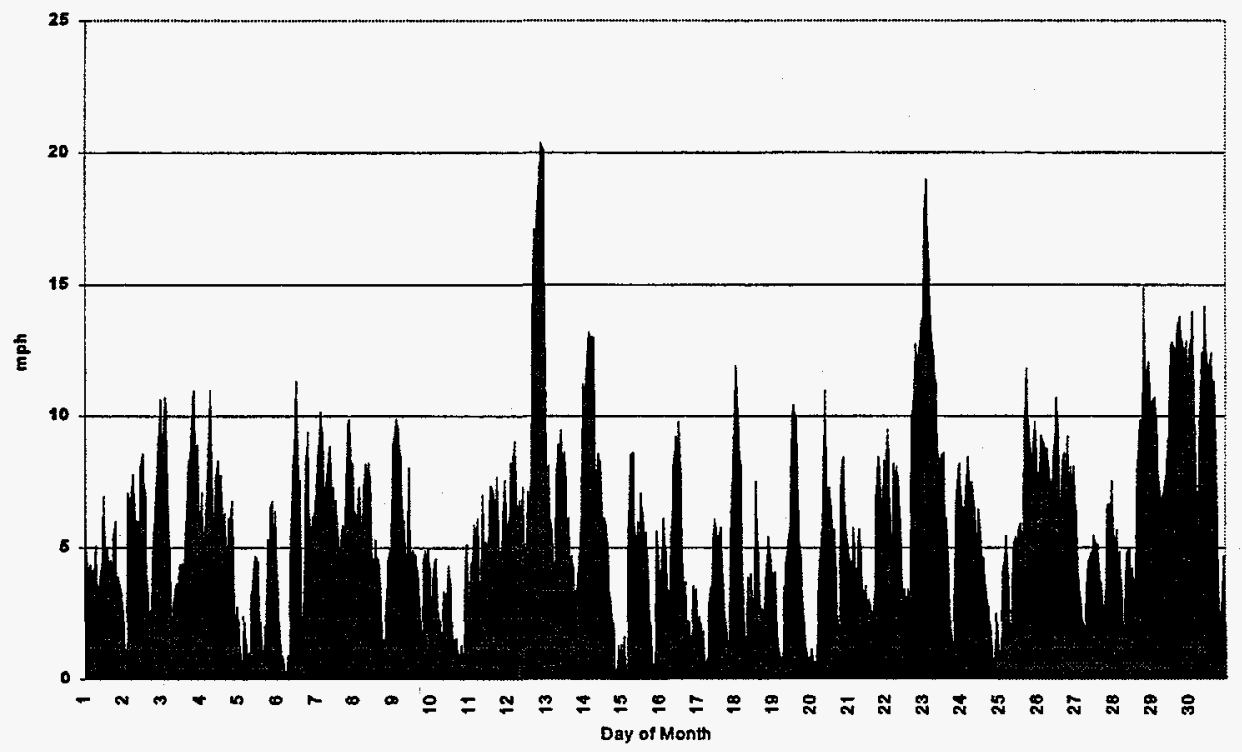

Fig. D.4. Hourly OPALCO wind speed at 133'-June 1994. 


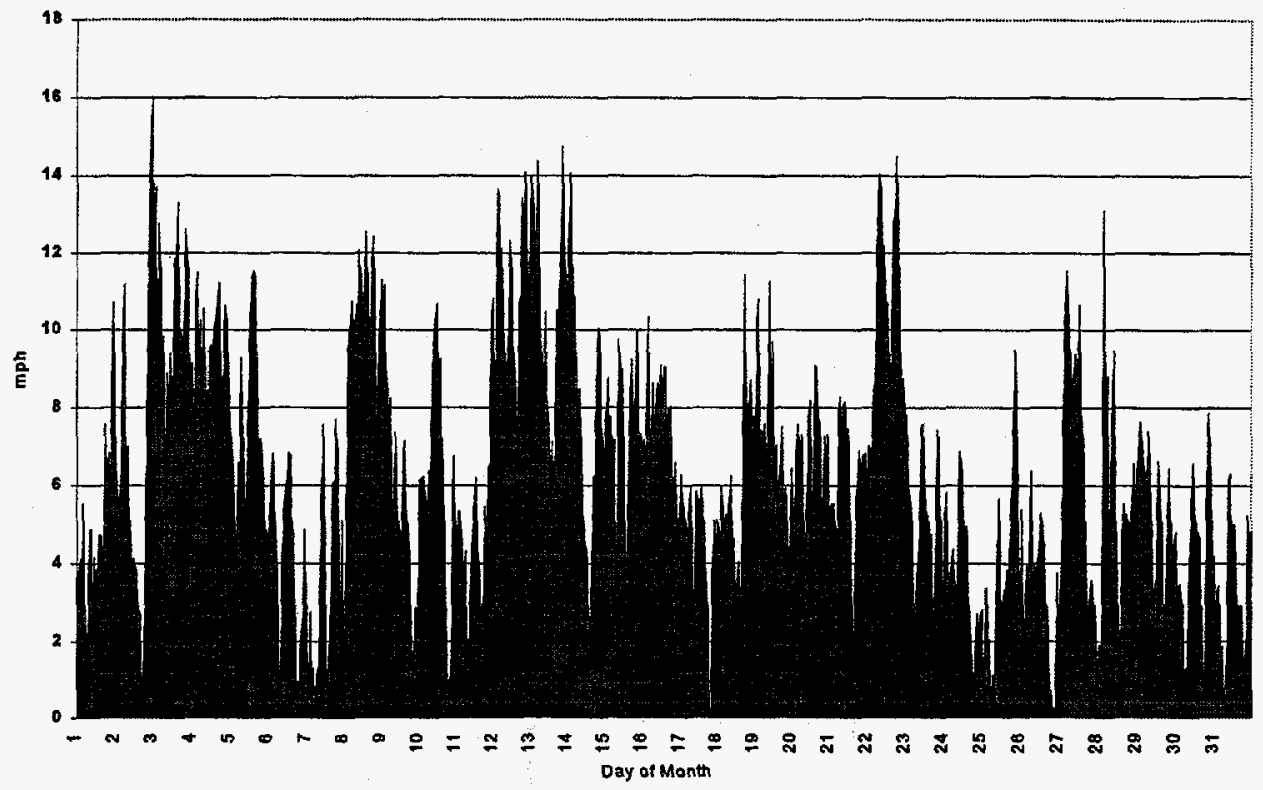

Fig. D.5. Hourly OPALCO wind speed at 133'_July 1994.

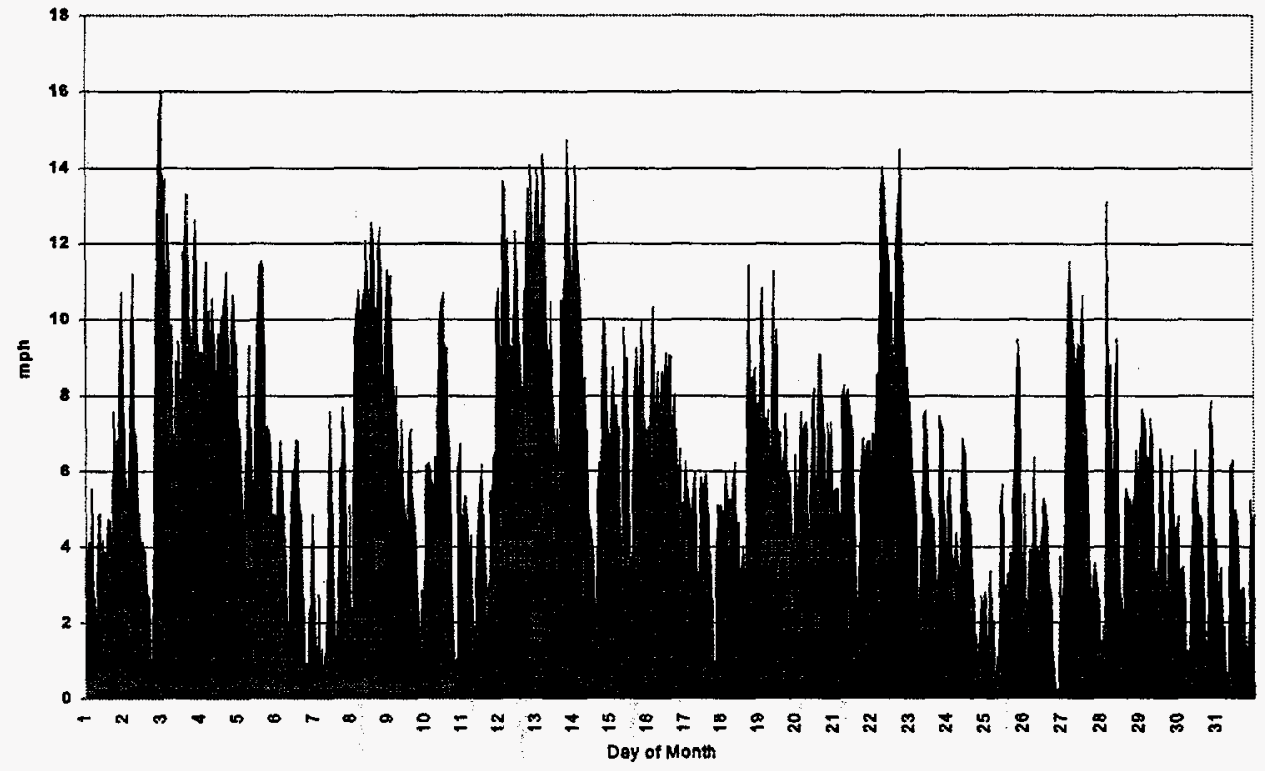

Fig. D.6. Hourly OPALCO wind speed at 133'-August 1994. 


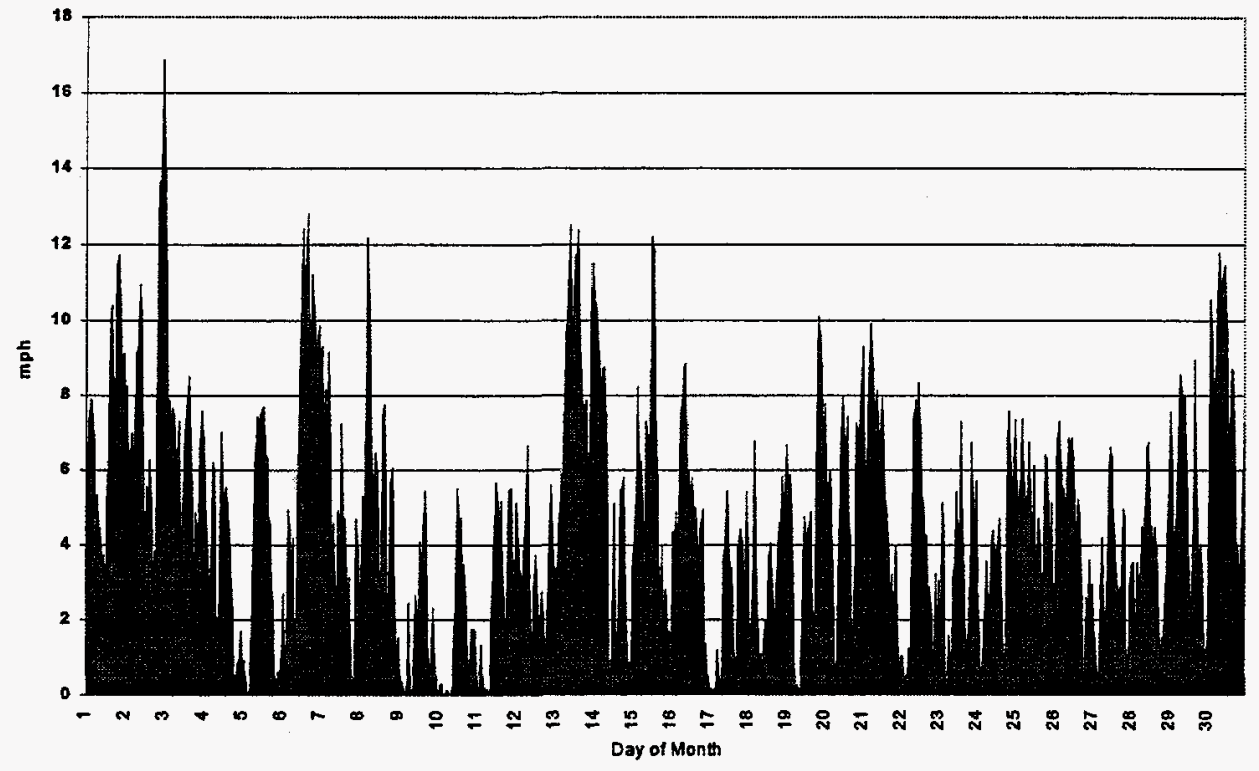

Fig. D.7. Hourly OPALCO wind speed at 133'-September 1994.

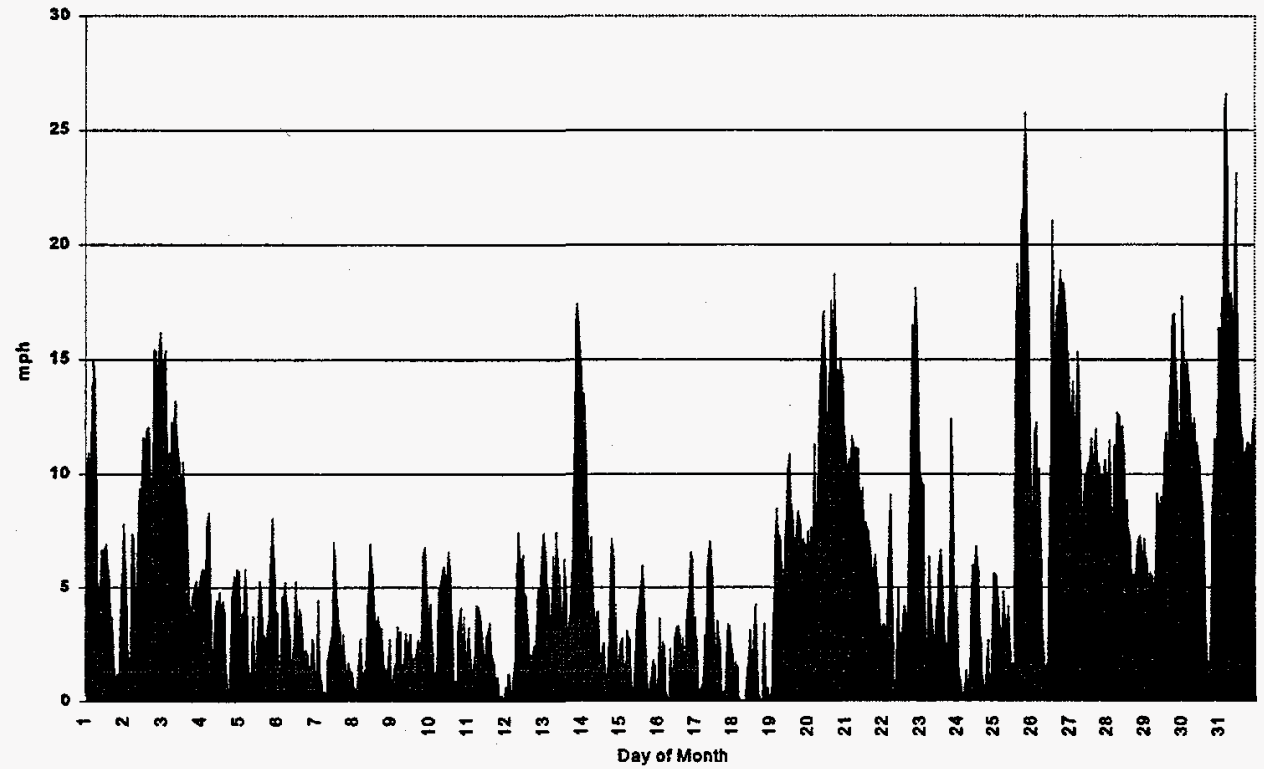

Fig. D.8. Hourly OPALCO wind speed at 133 '-October 1994. 


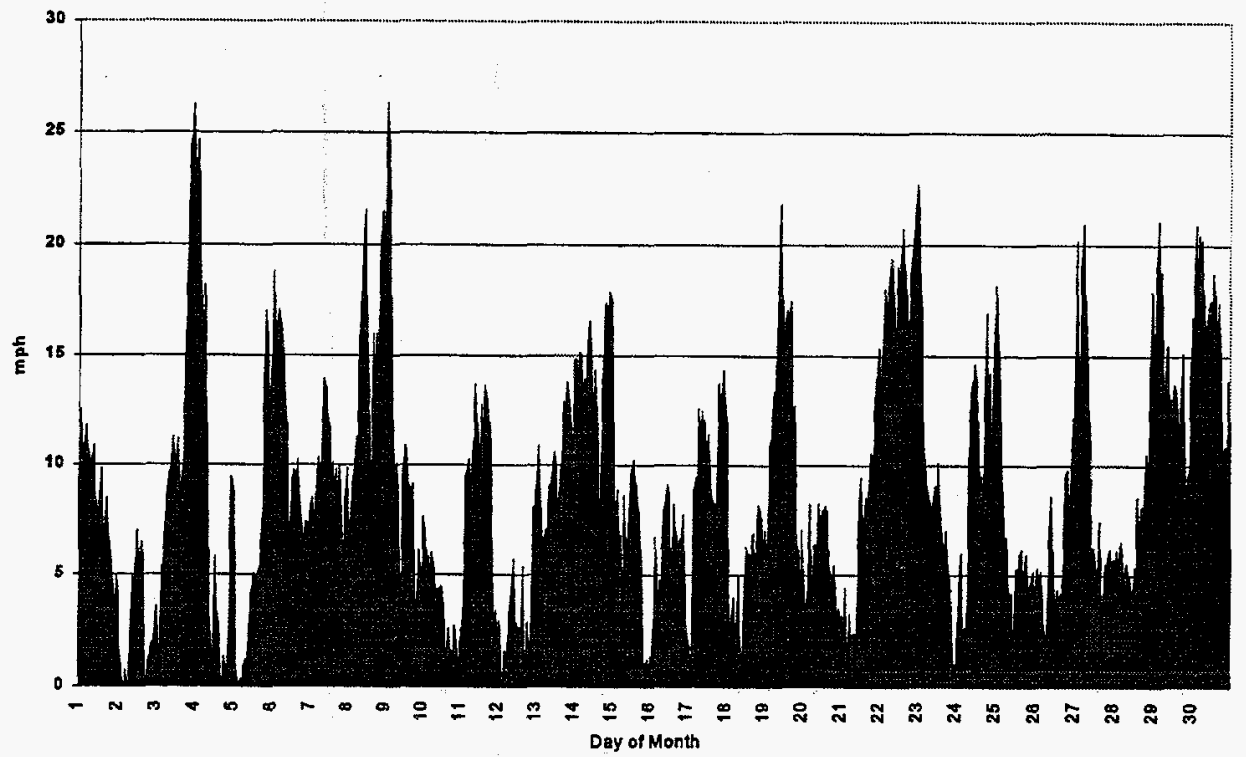

Fig. D.9. Hourly OPALCO wind speed at 133'-November 1994.

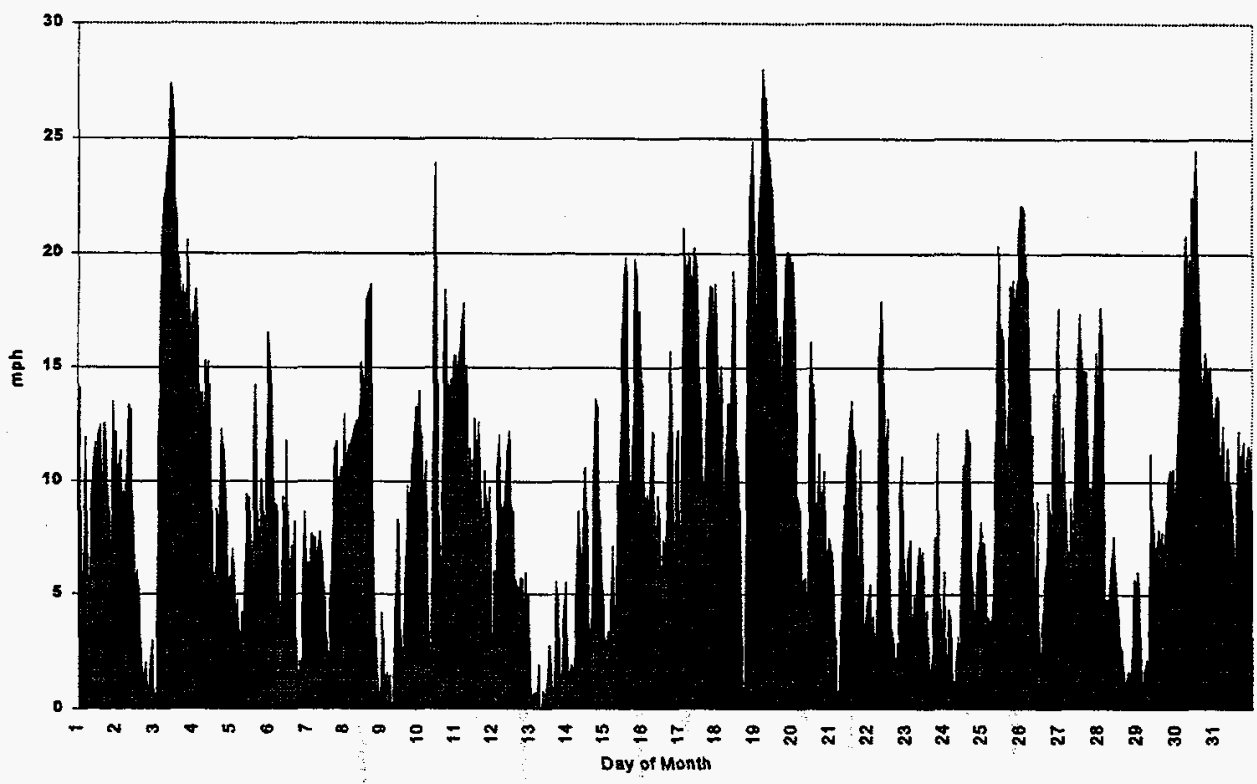

Fig. D.10. Hourly OPALCO wind speed at 133'-December 1994. 


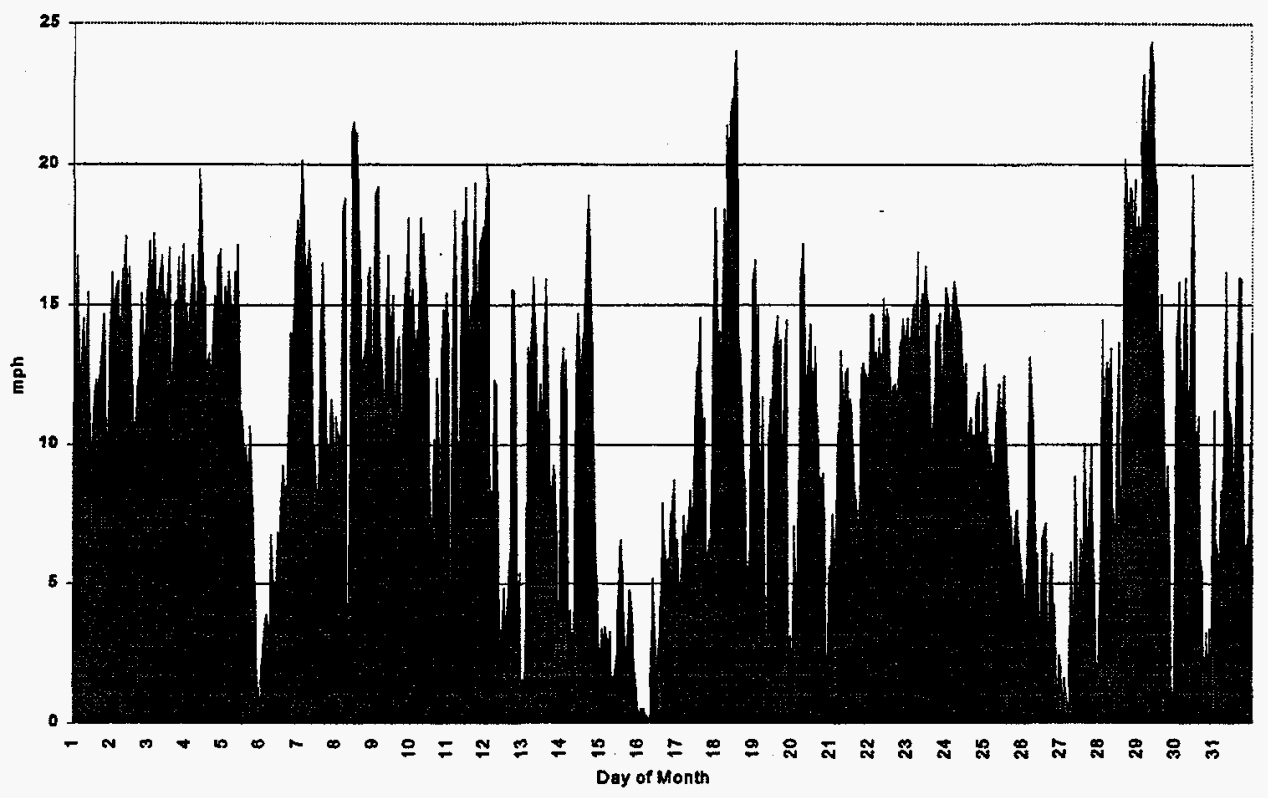

Fig. D.11. Hourly OPALCO wind speed at 133'-January 1995.

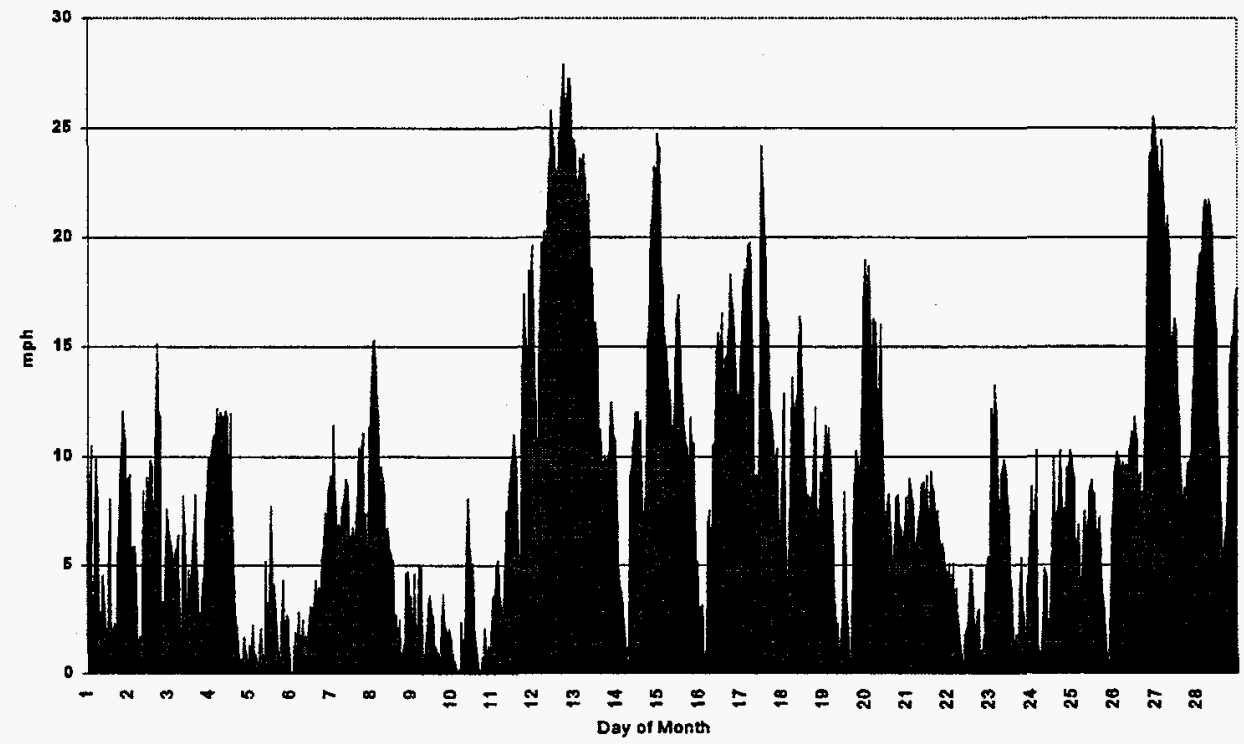

Fig. D.12. Hourly OPALCO wind speed at 133'-February 1995. 


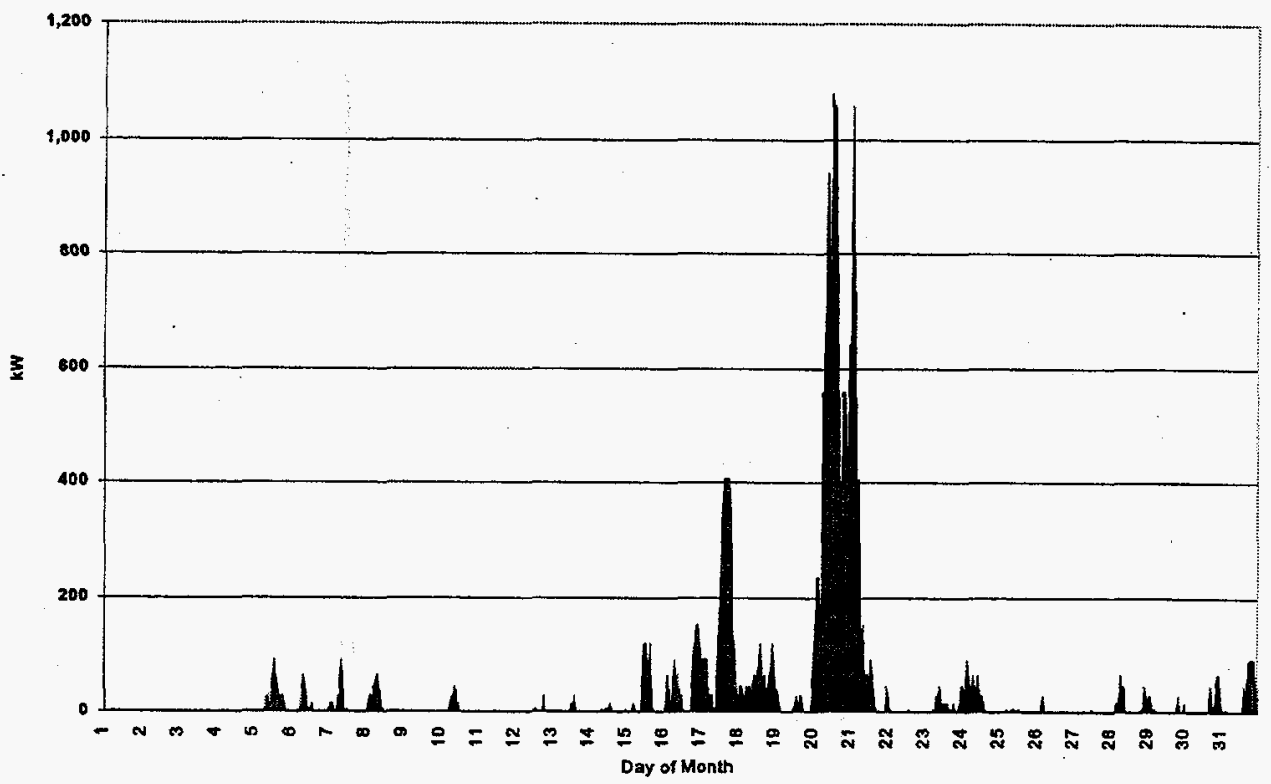

Fig. D.13. Hourly MW-scale wind plant performance: OPALCO 133'-March 1994.

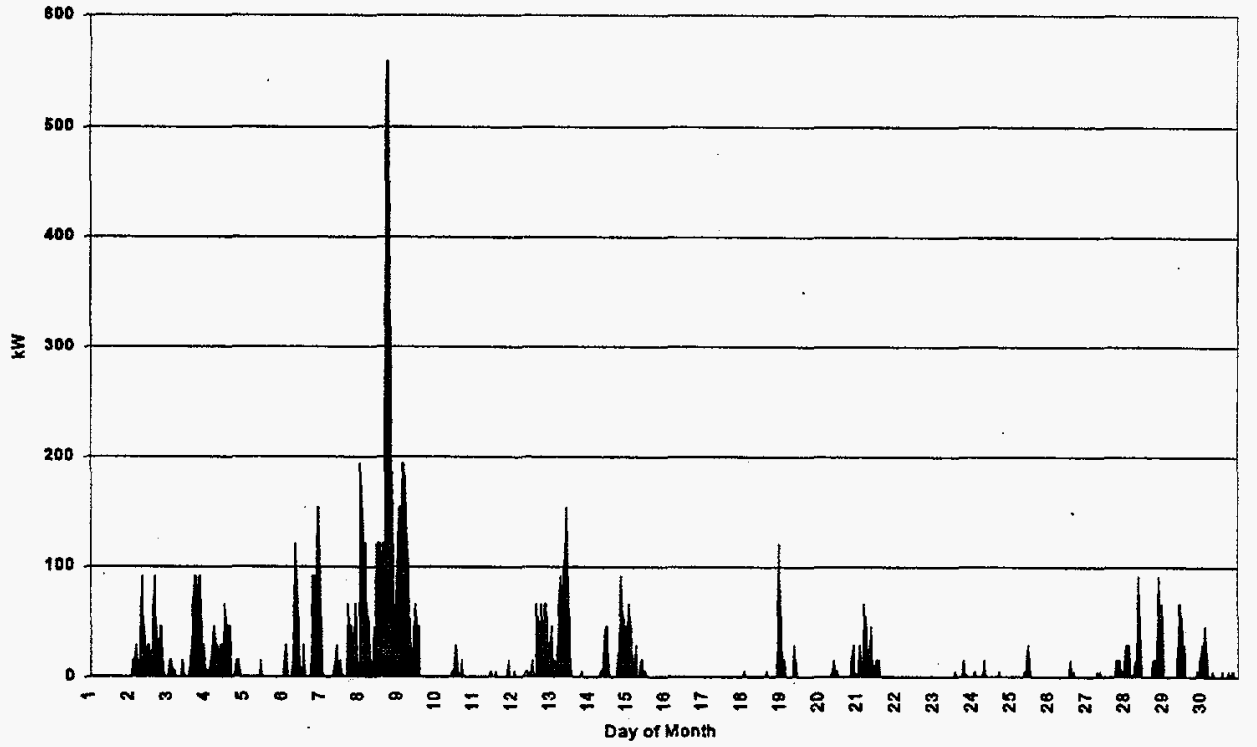

Fig. D.14. Hourly MW-scale wind plant performance: OPALCO 133'-April 1994. 


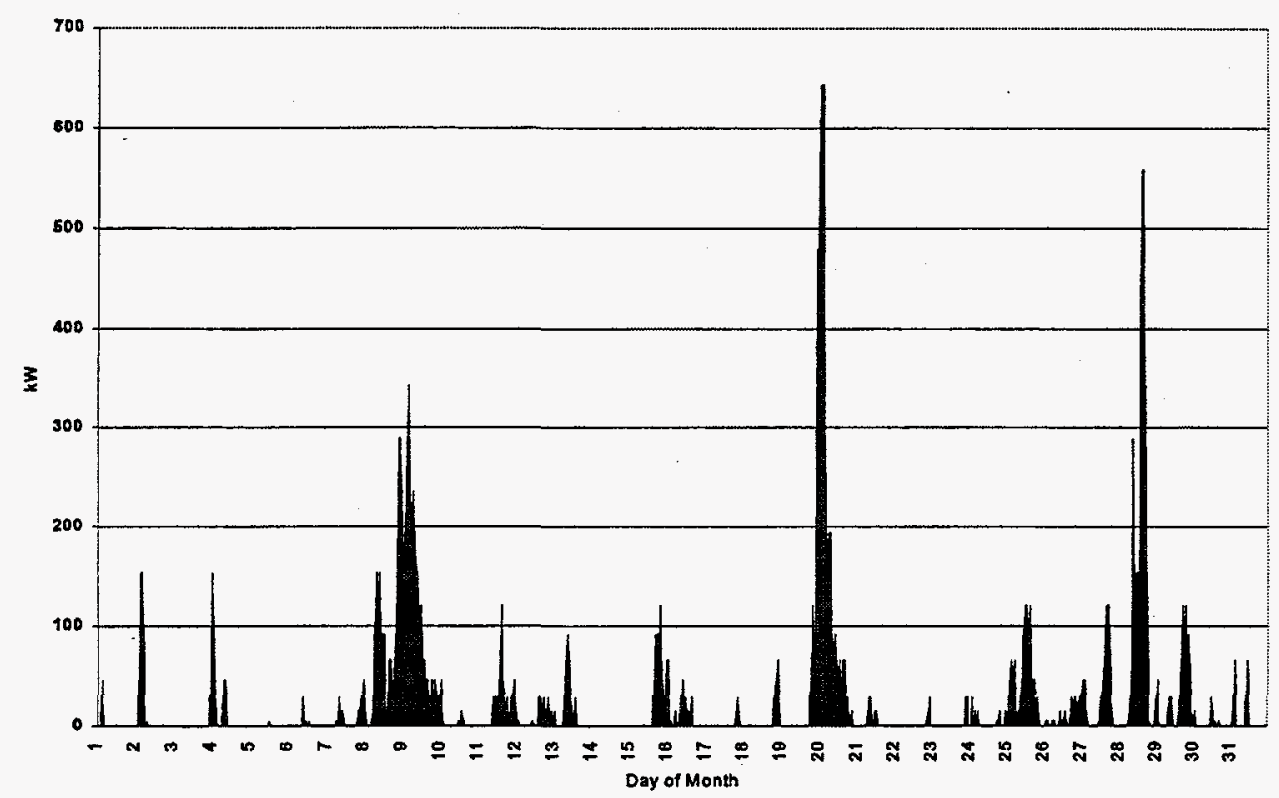

Fig. D.15. Hourly MW-scale wind plant performance: OPALCO 133'-May 1994.

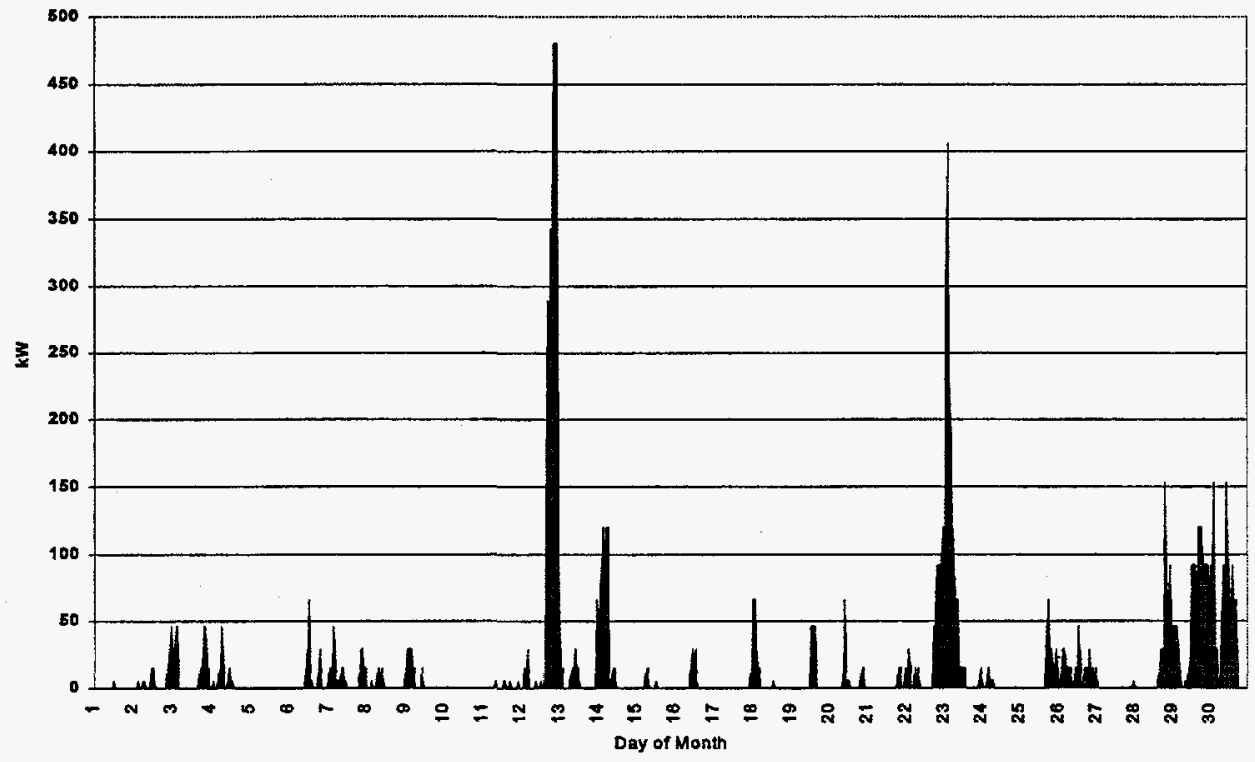

Fig. D.16. Hourly MW-scale wind plant performance: OPALCO 133'-June 1994.

D-9 


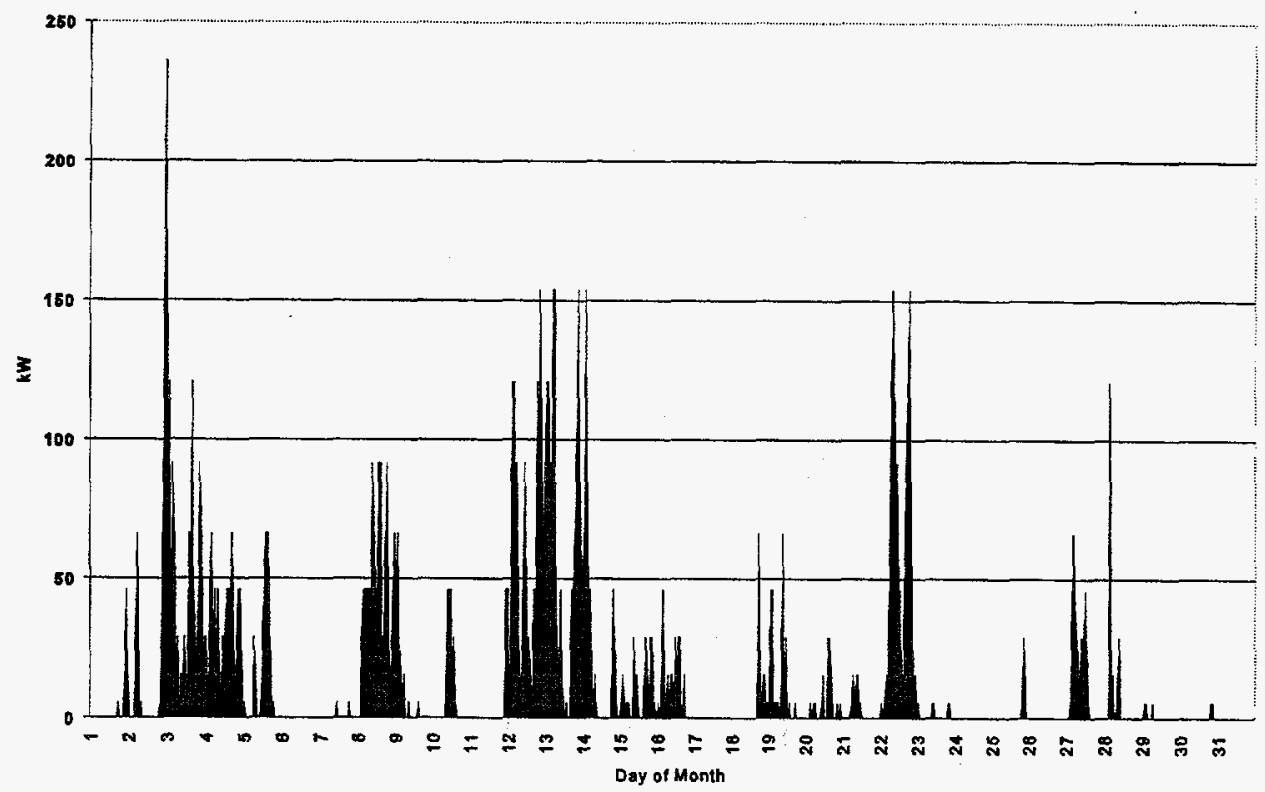

Fig. D.17. Hourly MW-scale wind plant performance: OPALCO 133'-July 1994.

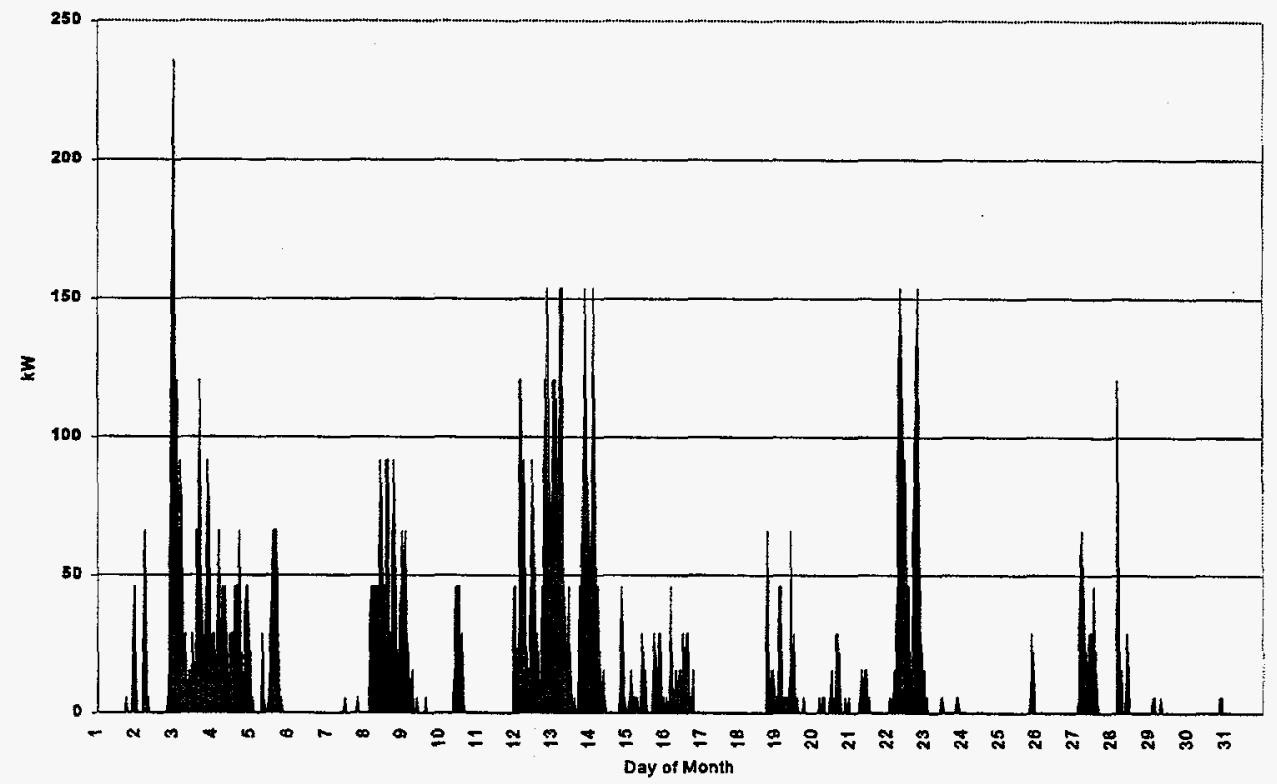

Fig. D.18. Hourly MW-scale wind plant performance: OPALCO 133'-August 1994. 


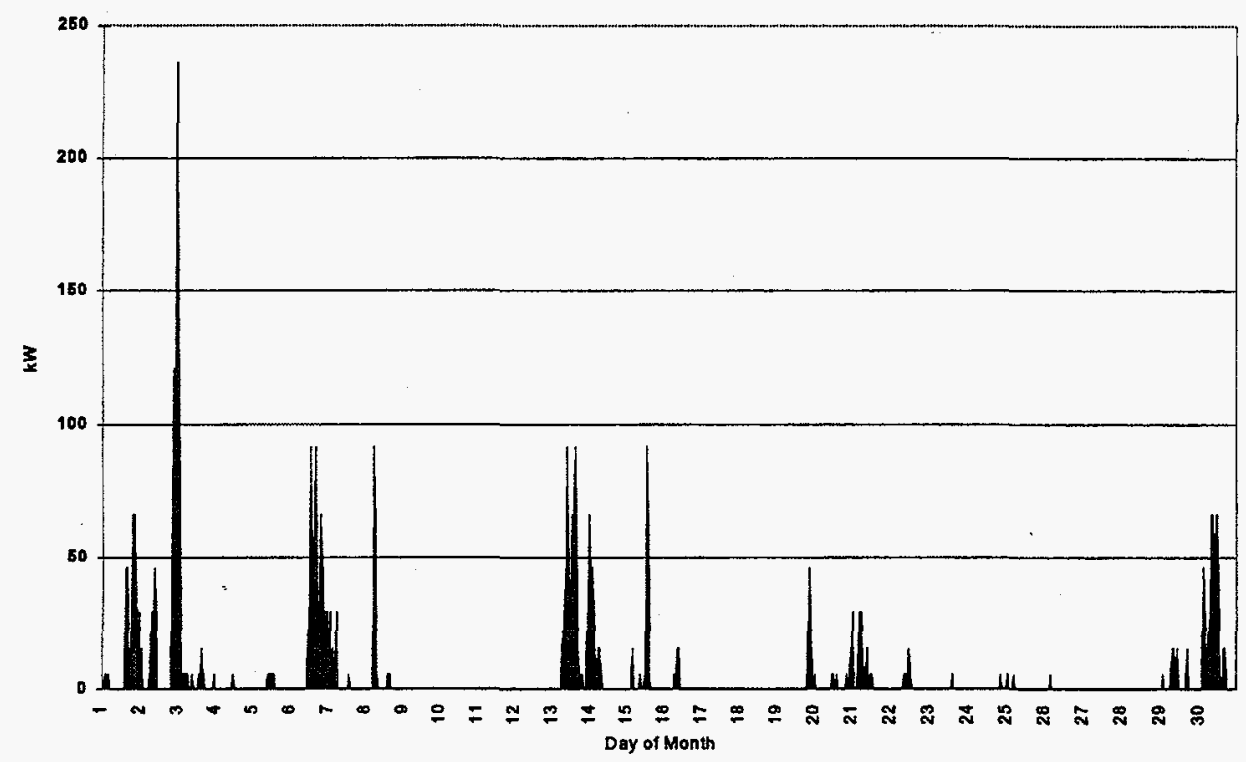

Fig. D.19. Hourly MW-scale wind plant performance: OPALCO 133'-September 1994.

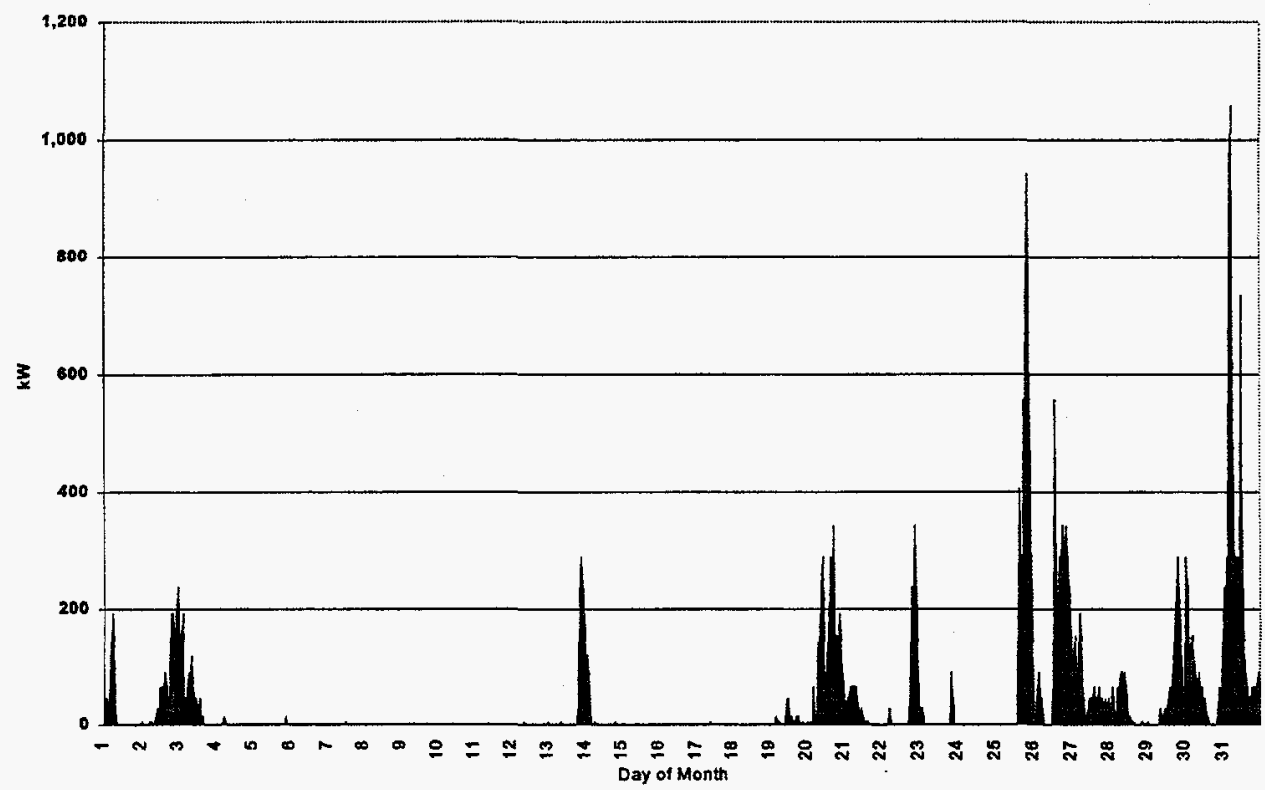

Fig. D.20. Hourly MW-scale wind plant performance: OPALCO 133'-October 1994.

D-11 


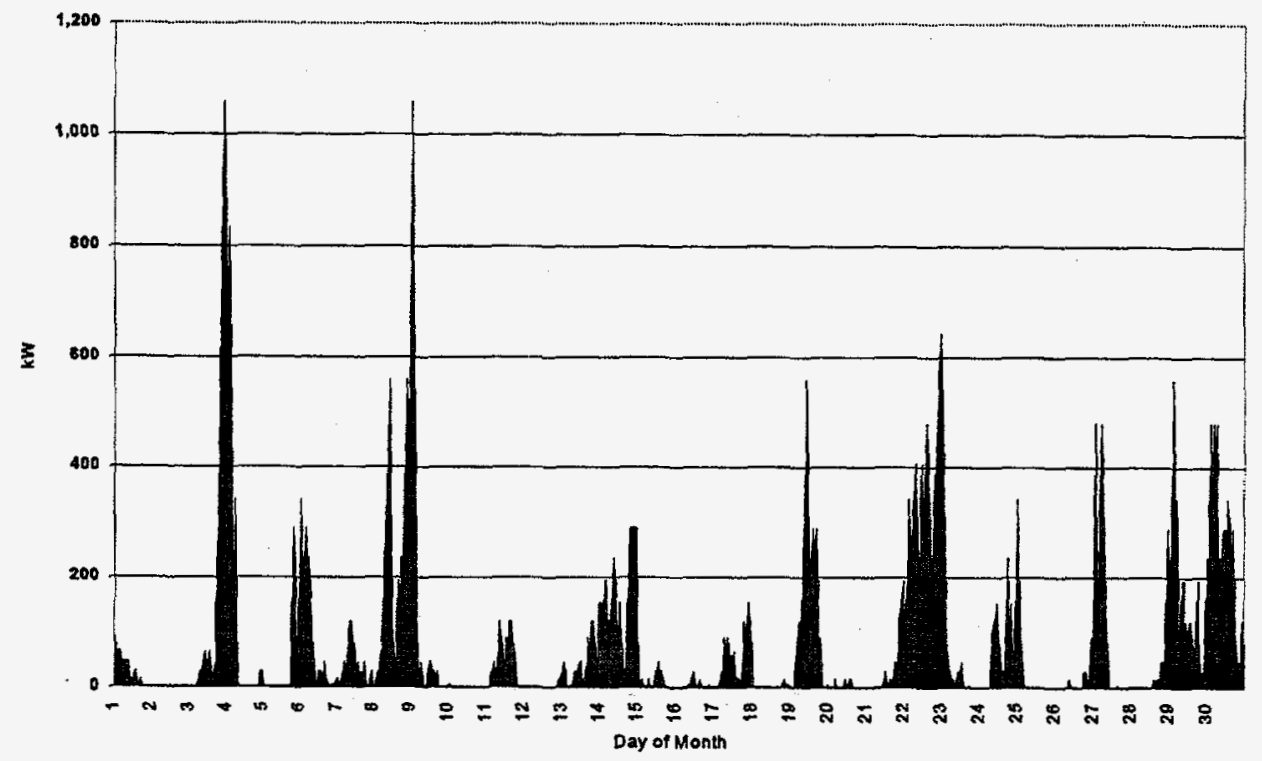

Fig. D.21. Hourly MW-scale wind plant performance: OPALCO 133'-November 1994.

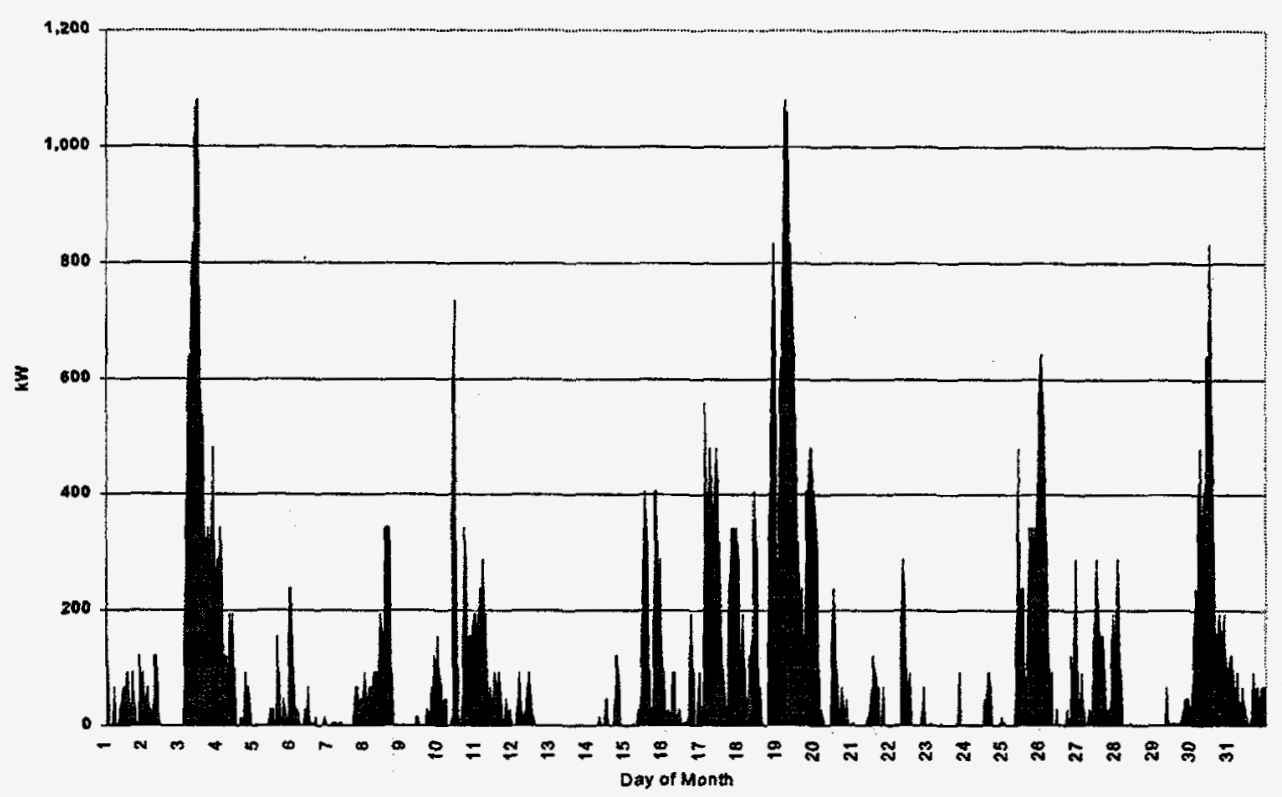

Fig. D.22. Hourly MW-scale wind plant performance: OPALCO 133'-December 1994.

D-12 


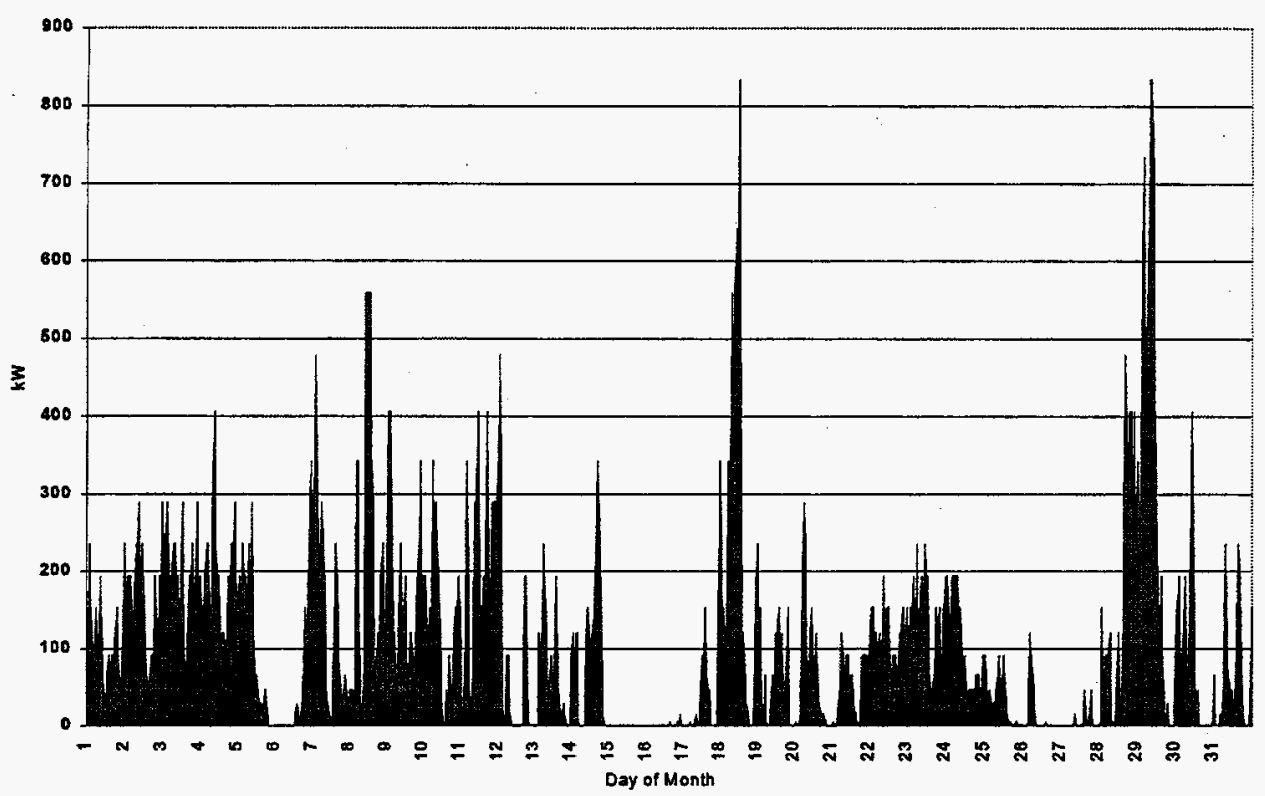

Fig. D.23. Hourly MW-scale wind plant performance: OPALCO 133'-January 1995.

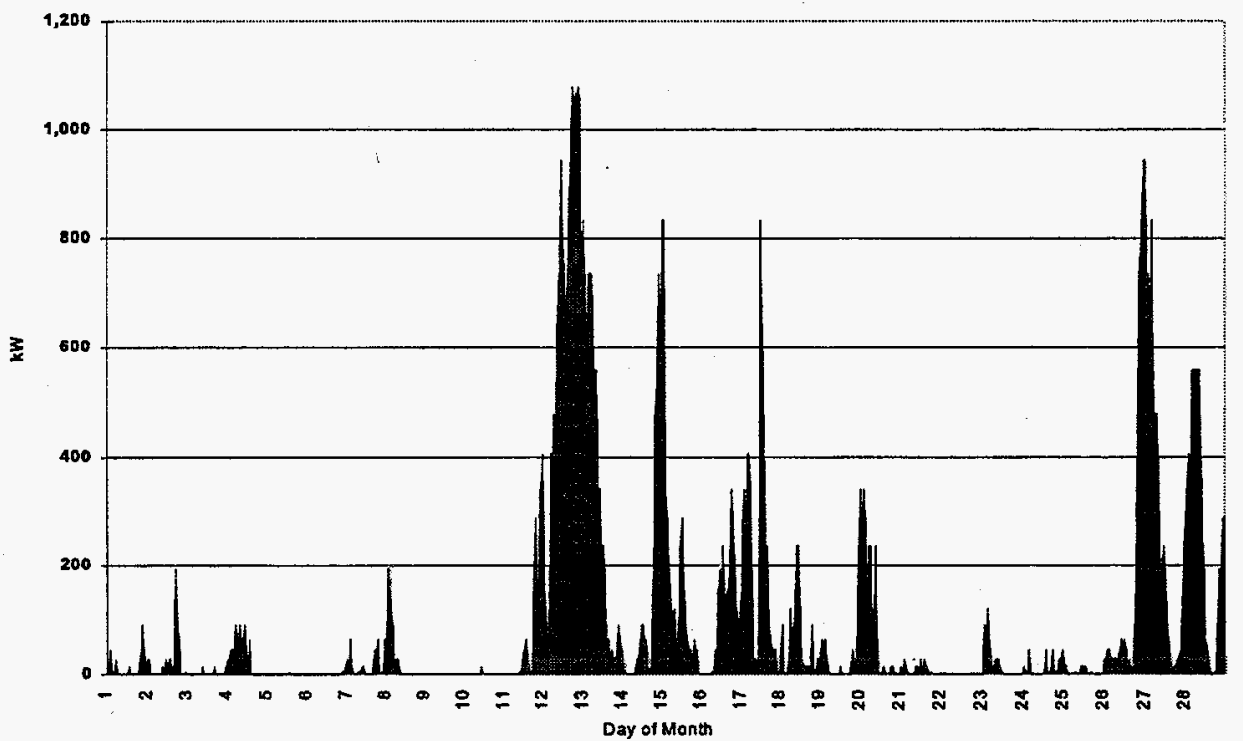

Fig. D.24. Hourly MW-scale wind plant performance: OPALCO 133' - February 1995. 


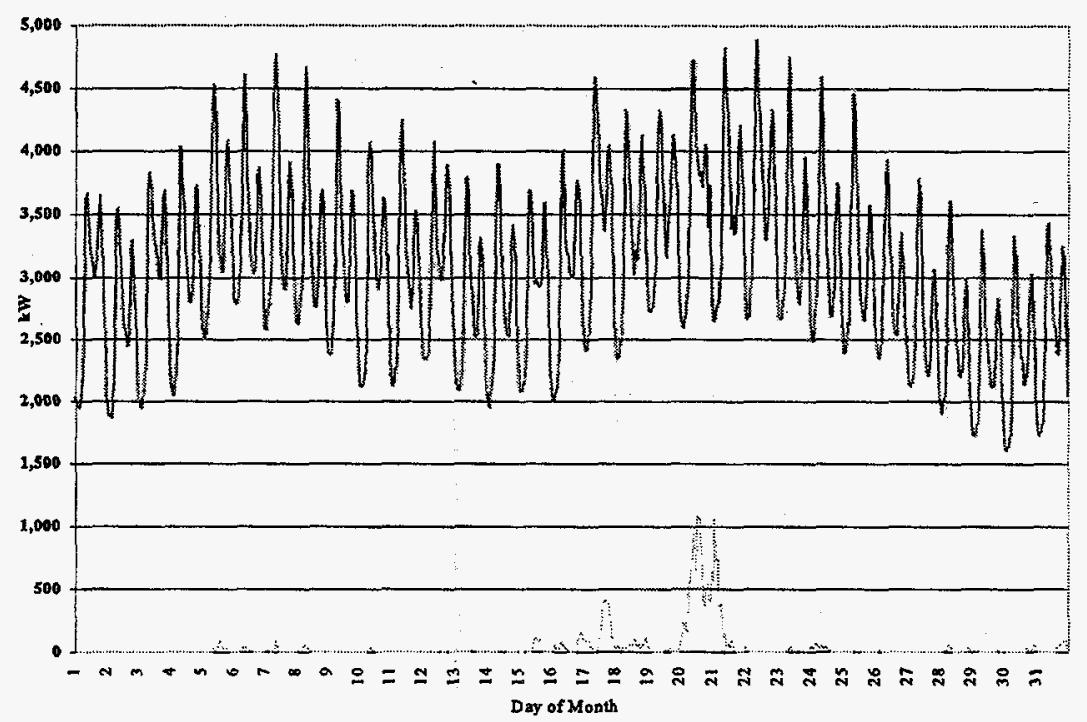

Land WT Oatput

Fig. D.25. Correlation between Eastsound load and MW-scale wind farm performance: OPALCO 133'

-March 1994.

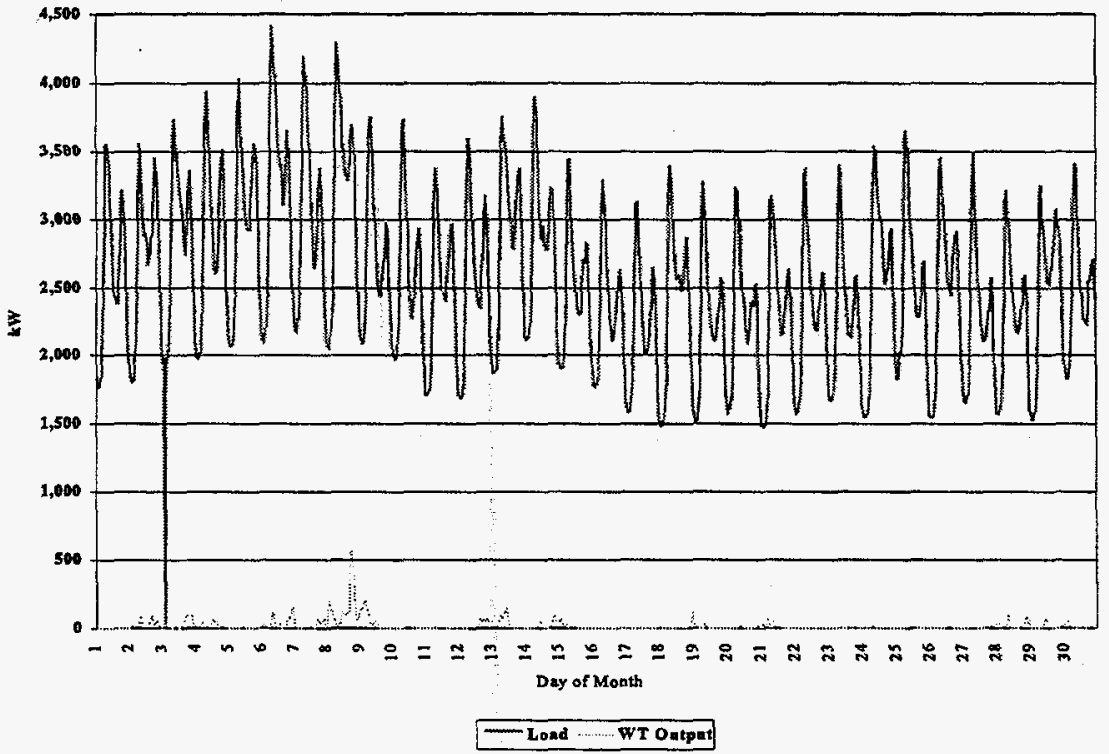

Fig. D.26. Correlation between Eastsound load and MW-scale wind farm performance: OPALCO 133' -April 1994.

D-14 


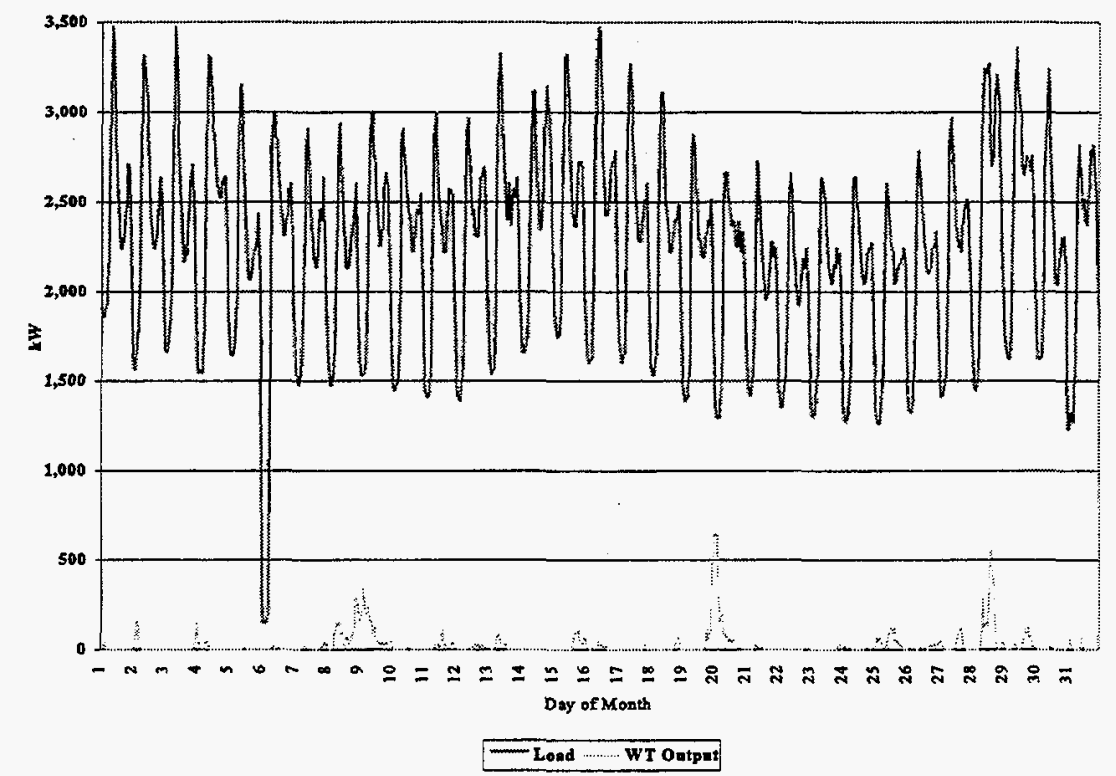

Fig. D.27. Correlation between Eastsound load and MW-scale wind farm performance: OPALCO 133' -May 1994.

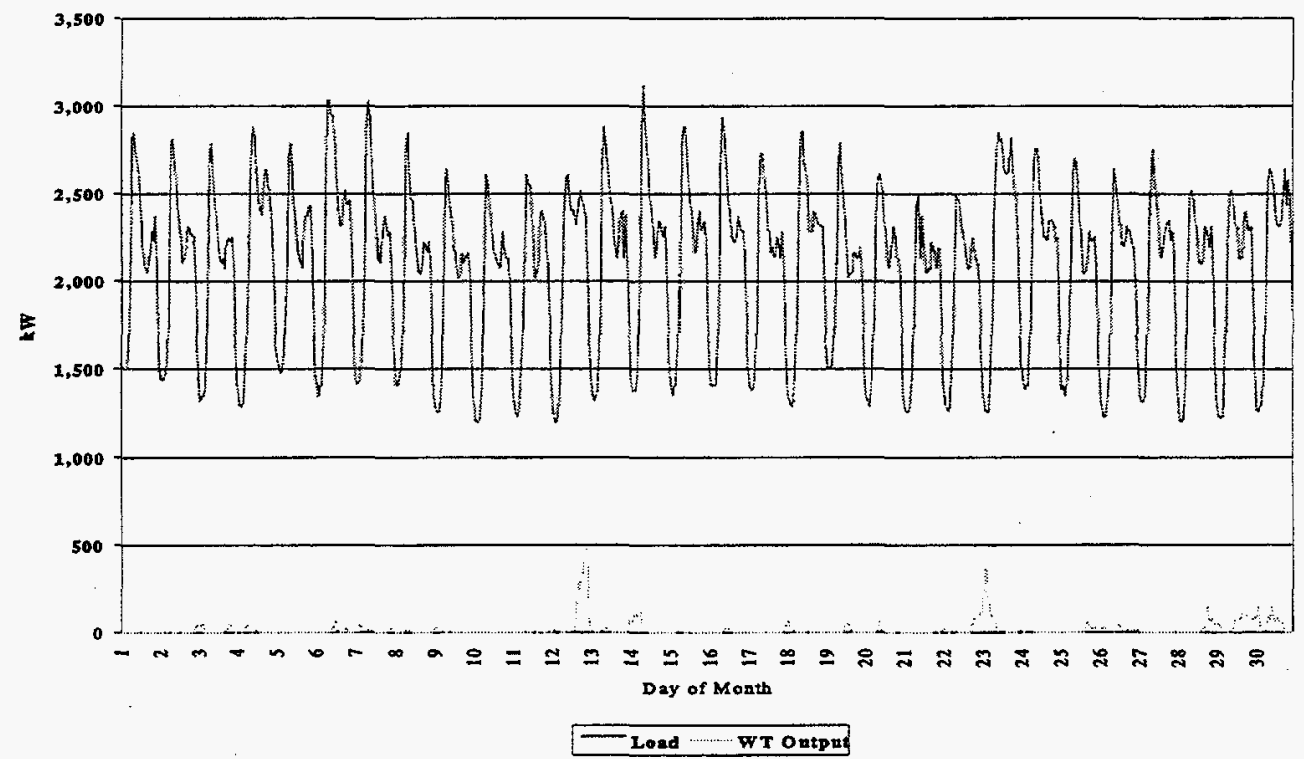

Fig. D.28. Correlation between Eastsound load and MW-scale wind farm performance: OPALCO 133' -June 1994. 


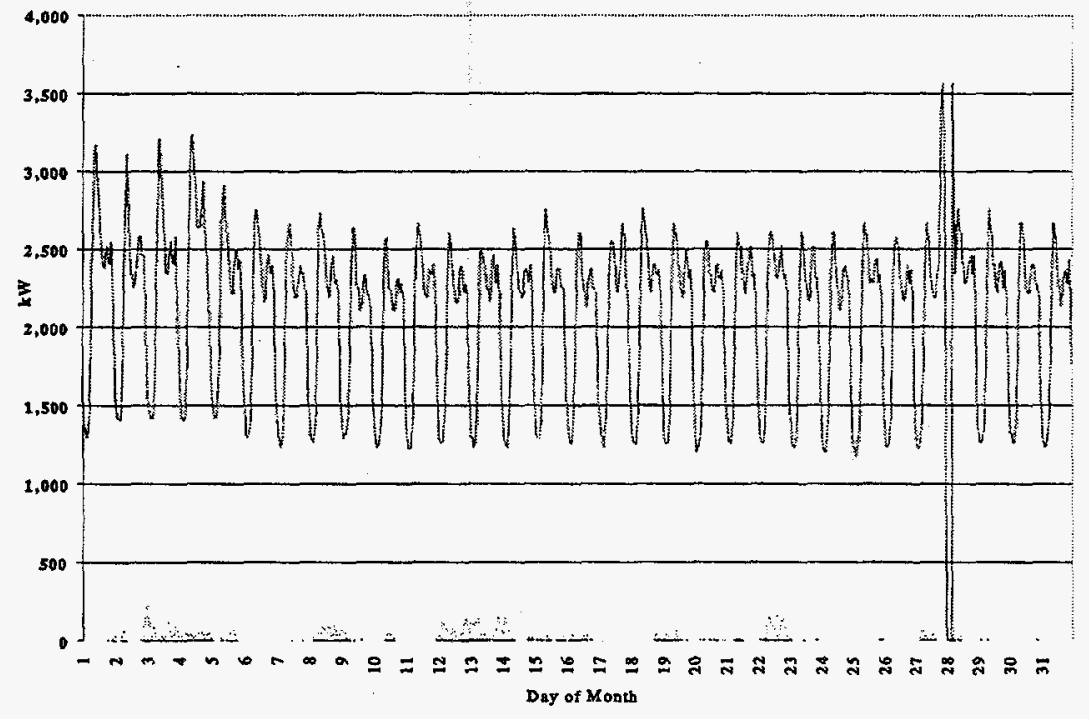

CLoad WT Outpu

Fig. D.29. Correlation between Eastsound load and MW-scale wind farm performance: OPALCO 133'

-July 1994.

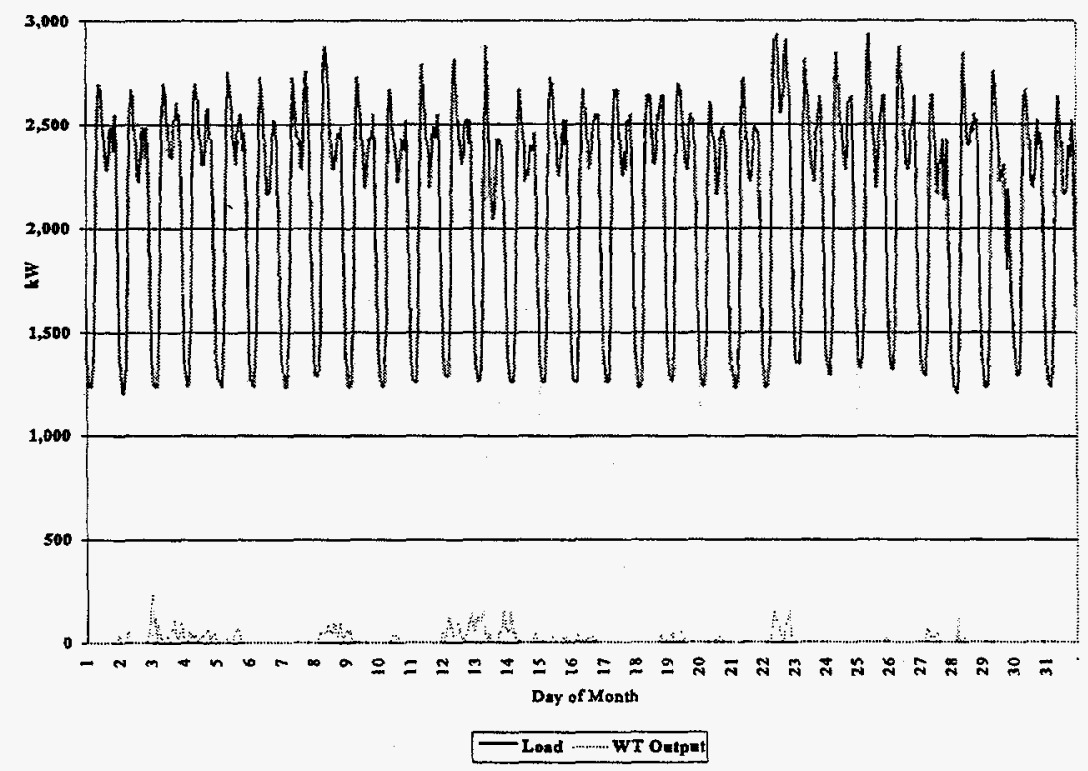

Fig. D.30. Correlation between Eastsound load and MW-scale wind farm performance: OPALCO 133'

-August 1994. 


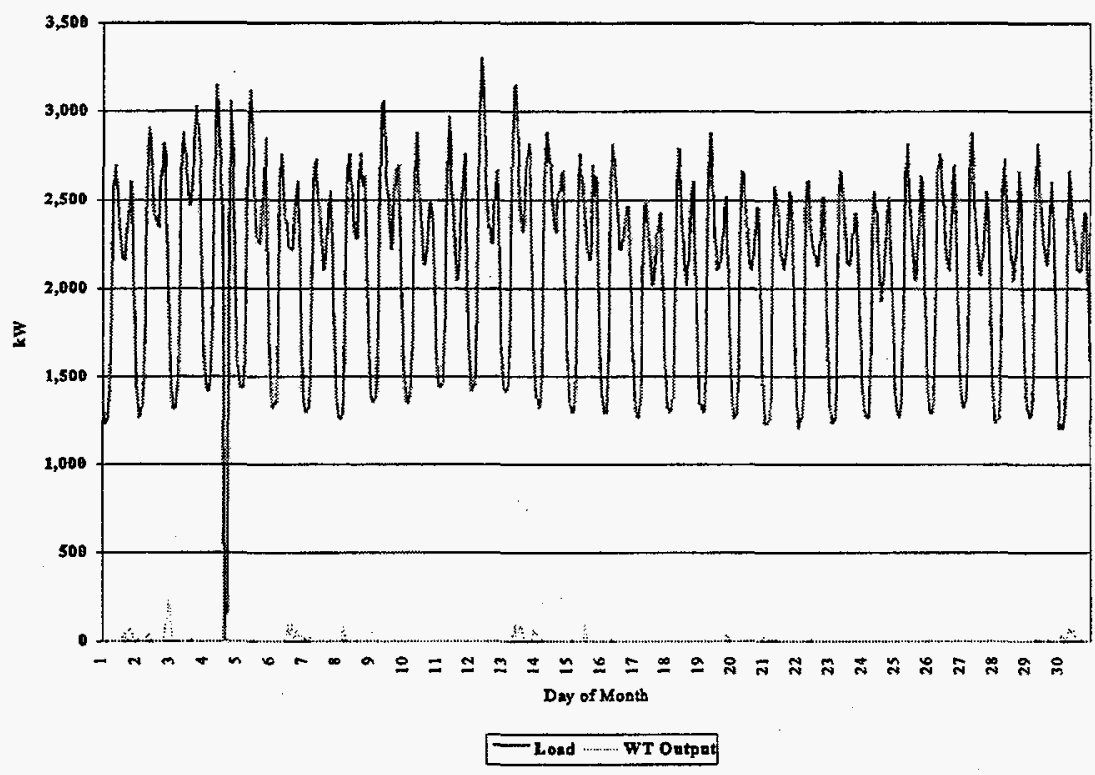

Fig. D.31. Correlation between Eastsound load and MW-scale wind farm performance: OPALCO 133' -September 1994.

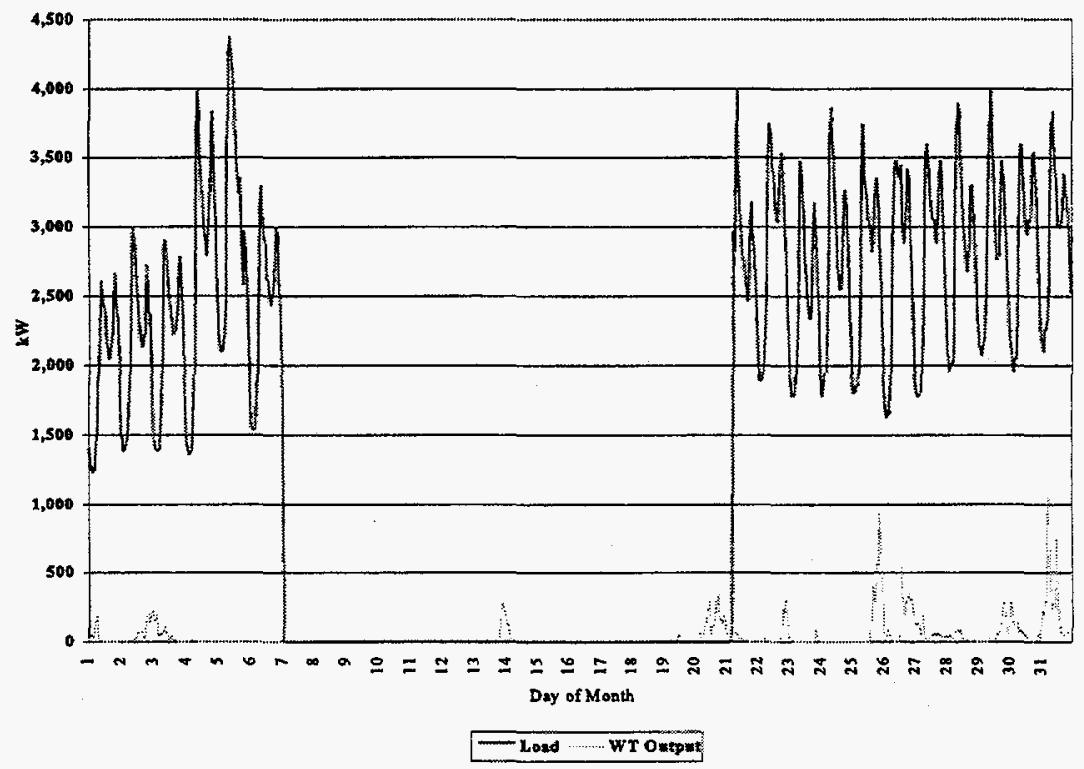

Fig. D.32. Correlation between Eastsound load and MW-scale wind farm performance: OPALCO 133' -October 1994. 
๑66I xәquәวәव-

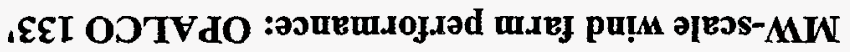

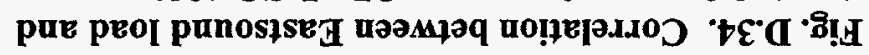

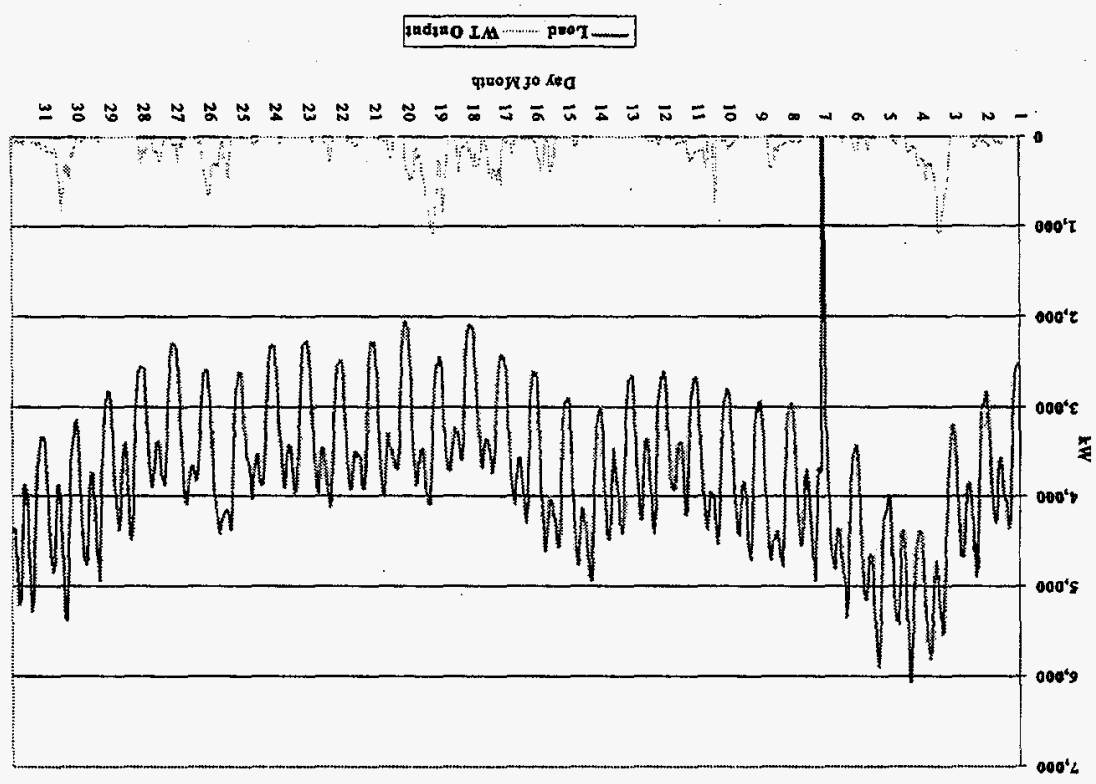

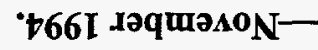

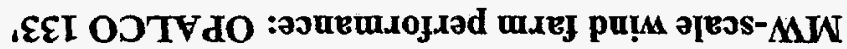

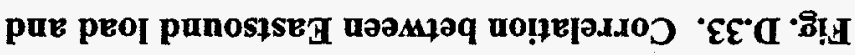

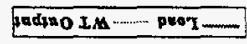

groow to kid

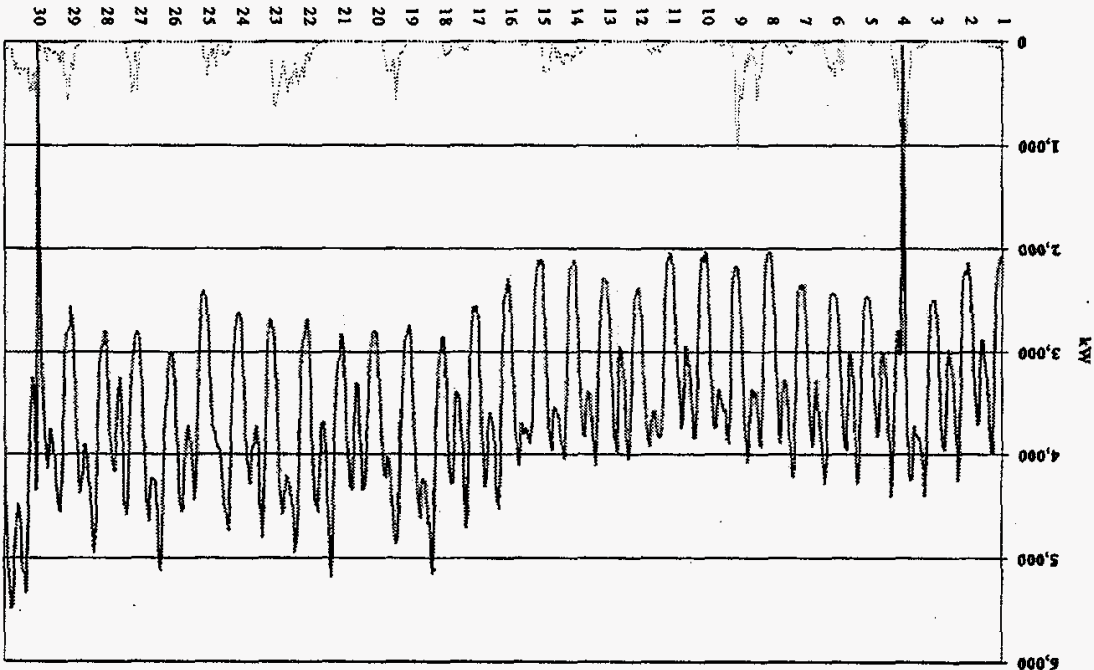




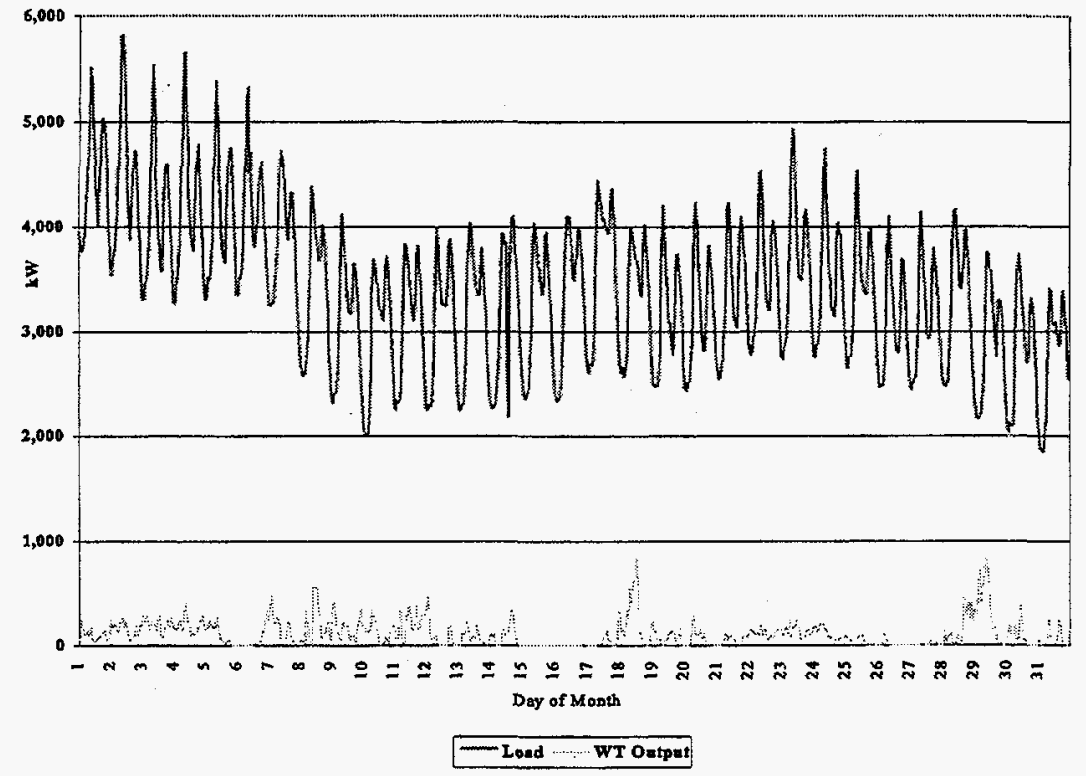

Fig. D.35. Correlation between Eastsound load and MW-scale wind farm performance: OPALCO $133^{\circ}$

-January 1995.

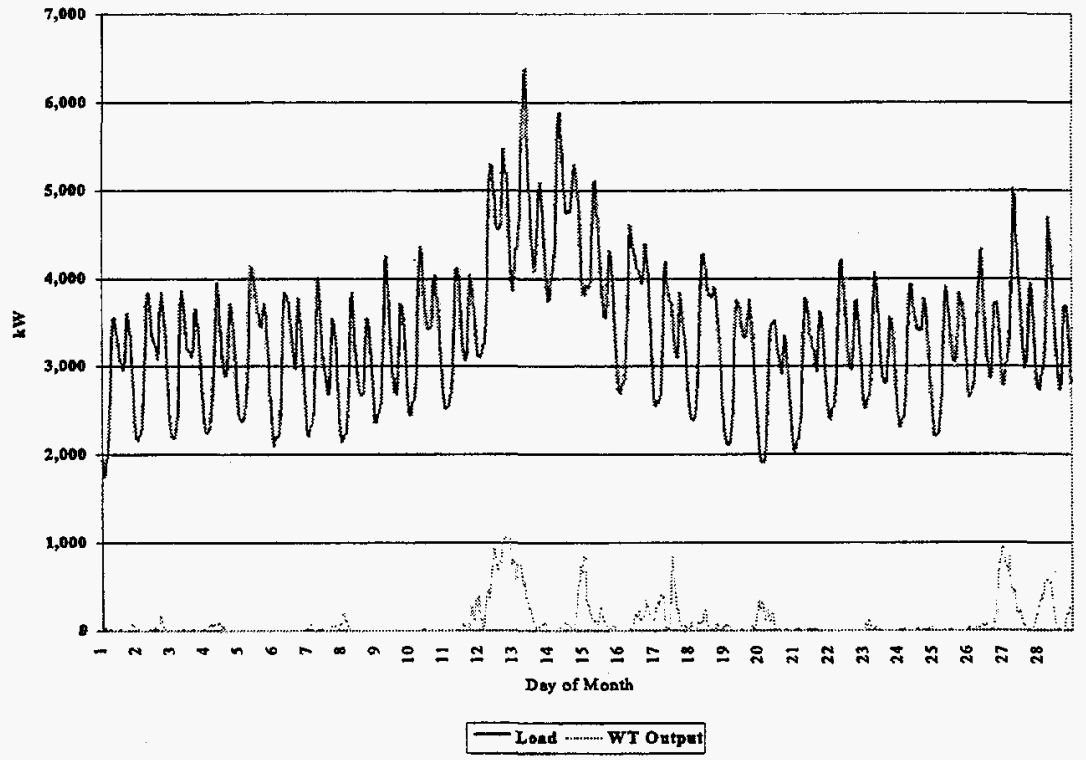

Fig. D.36. Correlation between Eastsound load and MW-scale wind farm performance: OPALCO 133'

-February 1995. 


\section{HOURLY WIND AND TEMPERATURE DATA FOR 1994/1995 WINTER}

Hourly temperature data were collected near Eastsound over the 1994/1995 winter period. Figures E.1 through E.3 present the hourly temperature data in degrees $\mathrm{F}^{0}$ with the measured hourly winds on Mt. Constitution at 163' for December 1994, January 1995 and February 1995 respectively. 


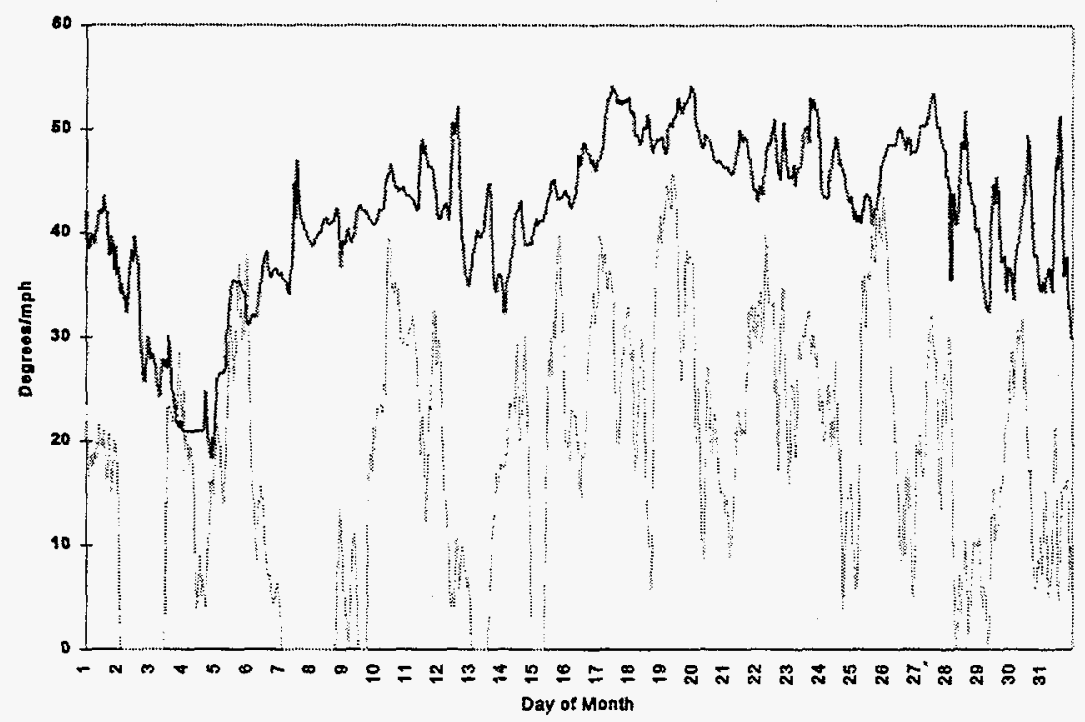

Wowind - Tomporaturo

Fig. E.1. Hourly wind and temperature-December 1994.

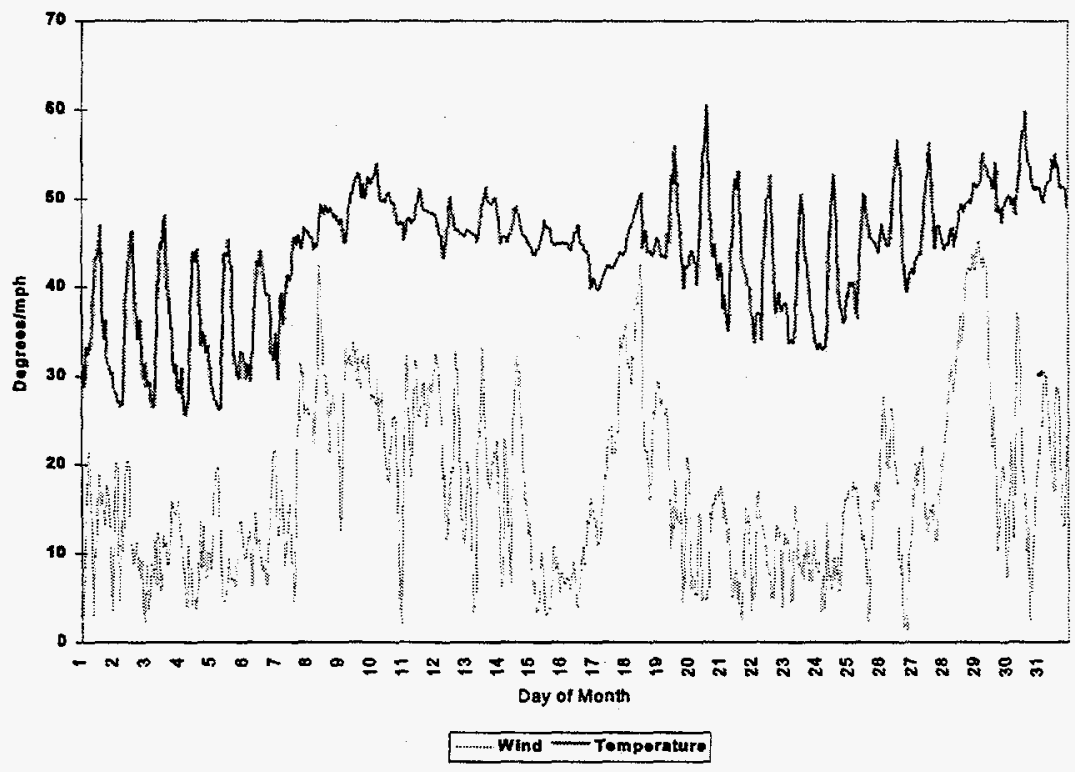

Fig. E.2. Hourly wind and temperature—January 1995. 


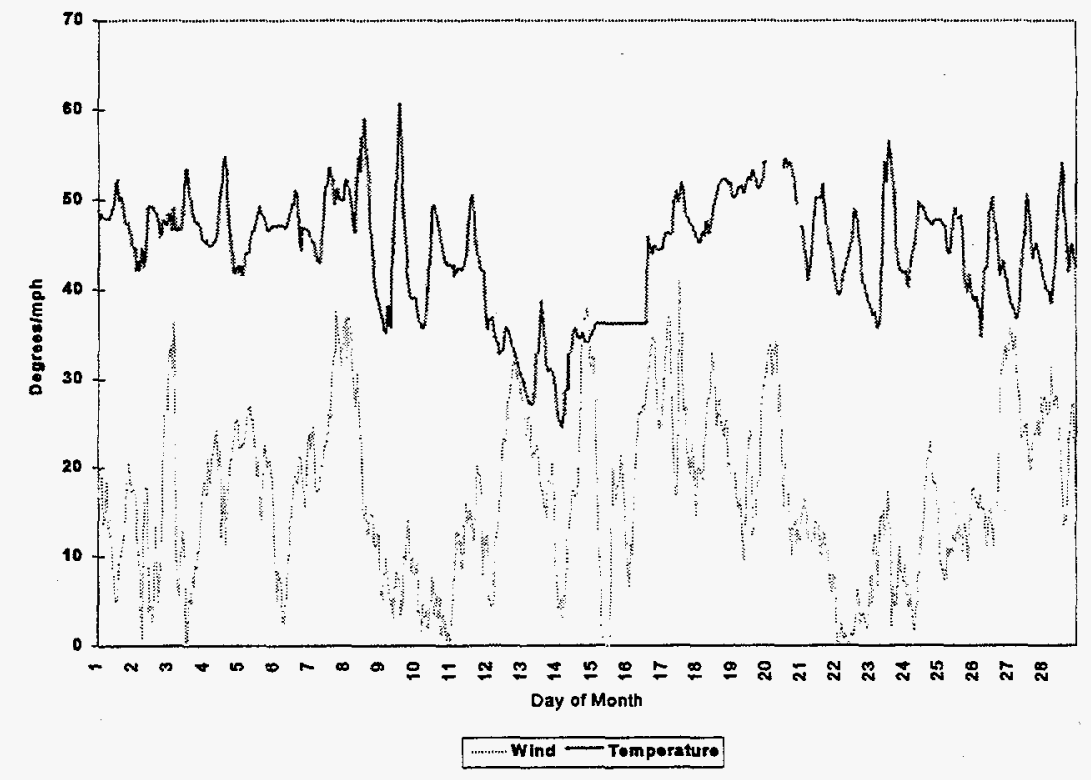

Fig. E.3. Hourly wind and temperature-February 1995. 
ORNL-Sub/96-SV115/1

\section{INTERNAL DISTRIBUTION}

1-10. P. R. Barnes

11. J. Christian

12. S. M. Cohn

13. G. E. Courville

14. T. R. Curlee

15. B. J. Kirby

16-25. B. W. McConnell

26. D. T. Rizy

27. R. B. Shelton
28. J. P. Stovall

29. J. W. Van Dyke

30. J. VanCoevering

31. ORNL Patent Office

32. Central Research Library

33. Document Reference Section

34. Y-12 Technical Library

35-36. Laboratory Records

37. Laboratory Records-RC

\section{EXTERNAL DISTRIBUTION}

38-47. Abbas A. Akhil, P.E., Senior Technical Staff Member, Sandia National Laboratories, Division 2525, Storage Batteries, P.O. Box 5800, Albuquerque, NM 87185

48. Lilia A. Abron, President, PEER Consultants, P.C., 1000 N. Ashley Drive, Suite 312, Tampa, FL 33602

49. American Public Power Assoc., 2301 M Street, NW, Washington, D.C. 20037-1484

50. Dan Ancona, Department of Energy, 1000 Independence Avenue, SW, Washington, D.C. 20585

51. Tom Bath, Office of Energy Management, National Renewable Energy Laboratory, 1617 Cole Boulevard, Golden, CO 80401-3393

52. Doug Bechtel, Orcas Power \& Light Company, Main Office: P.O. Box 187, Eastsound, WA 98245-0187

53. Dr. Jim Birk, Electric Power Research Institute, P.O. Box 10412, Palo Alto, CA 94303

54. Douglas R. Bohi, Director, Energy and Natural Resources Division, Resources for the Future, 1616 P Street NW, Washington, D.C. 20036

55. Nick Butler, Bonneville Power Administration, P.O. Box 3621, Palo Alto, CA 94303

56-65. Jack Cadogan, Department of Energy, 1000 Independence Avenue SW, Washington, D.C. 20585

66. Judith Carroll, Sustainable Energy Development Council, P.O. Box 12428, Austin, TX 78711

67. Lynn R. Coles, National Renewable Energy Laboratory, Analytic Studies Division, 1617 Cole Boulevard, Golden, CO 80401

68. John Cooley, Chugach Electric Association, 5601 Minnesota Drive, Anchorage, AK 99519

69. Kevin Cousineau, Zond Energy Systems, Inc., P.O. Box 1910, Tehachapi, CA 93561

70. Declan Daly, General Electric, 1501 Roanoke Blvd., Room 435, Salem, VA 24153

71. Thomas Diamantis, P.E., Niagara Mohawk Power Corporation, 300 Erie Boulevard West, Syracuse NY 13202

72. Pascal De Laquil, Technology Manager, Bechtel Corporation, P.O. Box 193965, San Francisco, CA 94119-3965

73. Thomas E. Drabek, Professor, Department of Sociology, University of Denver, Denver, CO 80208-0209

74. Steven W. Eckroad, Electric Power Research Institute, P.O. Box 10412, Palo Alto, CA 94303 
75. P. R. Ellis, Consulting Electrical Engineer, Ellis Power Engineering, 4695 David Way, San Bernardino, CA 92404

76. James Fangue, TU Electric, 1601 Bryan Street, Room 19030, Dallas, TX 75201

77. Paul Ferron, BPA, P.O. Box 3621-EO, Portland, OR 97208

78. Robert Flemming, AC Battery Corp., 2010 Energy Drive, P.O. Box 325, East Troy, WI 53120

79. Larry Goldstein, National Renewable Energy Laboratory, 409 12th Street, S.W., Washington, DC 20024

80. Mark E. Haller, ENERCON, P.O. Box 883, Hudson, WI 54016-0883

81. Miles Hamano, Hawaiian Electric Company, P.O. Box 2750, Honolulu, HI 96840

82. Stephen G. Hildebrand, Director, Environmental Sciences Division, Oak Ridge National Laboratory, P.O. Box 2008, Oak Ridge, TN 37831-6037

83. J. Michael Hinga, Delphi Energy \& Engine Management, P.O. Box 502650 P39-1092, Indianapolis, IN 46240

84. Allan Hoffman, DOE Office of Utility Technologies, CE-10, Forrestal Building, Room 6C-036, 1000 Independence Avenue, SW, Washington, D.C. 20585

85. John Hoffner, Program Manager, Alternative Energy, Austin Electric Utility, 721 Barton Springs Road, Austin, TX 78704

86. George Hunt, GNB Technologies, Woodlake Corporate Park, 829 Parkview Blvd., Lombard, IL 60148-3249

87. Joe Iannucci, Distributed Utility Associates, 3170 Crow Canyon Road, Suite 140, San Ramon, CA 94583

88. Landis Kannberg, PG\&E Research \& Development, 3401 Crow Canyon Road, Suite 100, San Ramon, CA 94583

89. J. Kappenman, Minnesota Power, 30 W. Superior Street, Duluth, MN 55802

90. Joseph L. Koepfinger, Director, Systems Studies and Research, Duquesne Light Company, One Oxford Center, 301 Grant Street (19-5), Pittsburgh, PA 15279

91. Deborah Lewis, Senior System Planner, Electric Resource Planning, Lower Colorado River Authority, P.O. Box 220, Austin, TX 78767-0220

92. Ron Loose, Department of Energy, 1000 Independence Avenue, SW, Washington, D.C. 20585

93. David Meakin, Solar Energy Industries Association, 777 N. Capitol Street, NE, Suite 805, Washington, D.C. 20002-4226

94. Hans Meyer, Ominion Power Engineering Corp., 2010 Energy Drive, P.O. Box 879, East Troy, WI 53120

95. Alva K. Nakamura, Hawaiian Electric Company, P.O. Box 2750, Honolulu, HI 96840

96. Clyde Negata, Hawaii Electric Light Company, Inc., P.O. Box 1027, Hilo, HI 96721

97. Stuart Nelson, Transmission Planning, Transmission Analysis Department, Lower Colorado River Authority, P.O. Box 220, Austin, TX 78767

98. S. Nilsson, Program Manager, Electric Power Research Institute, Electrical Systems Division, 3412 Hillview Avenue, P.O. Box 14012, Palo Alto, CA 94303

99. Benjamin Norris, Pacific Gas \& Electric, 2303 Camino Ramon, Suite 200, San Ramon, CA 94583

100-109. Phil Overholt, DOE Office of Energy Management, CE-14, 1000 Independence Avenue, SW, Washington, D.C. 20585

110. Dr. Christine Platt, U.S. Department of Energy, 1000 Independence Avenue, S.W., Washington, DC 20585

111. James E. Rannels, Director, Photovoltaic Technology Division, U.S. Department of Energy, 1000 Independence Avenue, S.W., Washington, D.C. 20585

112. T. W. Reddock, Electrotek Concepts, Inc., 10305 Dutchtown Road, Suite 103, Knoxville, TN 37932 
113. John C. Schaefer, Consultant, P.O. Box 60785, Palo Alto, CO 94306

114. Scott Sklar, Solar Energy Industries Association, 777 N. Capitol Street, NE, Suite 805, Washington, D.C. 20002-4226

115. Randall Swisher, Executive Director, American Wind Energy Association, 777 N. Capitol Street, NE, Suite 805, Washington, D.C. 20002

116. Dr. Philip Symons, 1295 Kelly Park Circle, Morgan Hill, CA 95037-0813

117. L. L. Taylor, Northern States Power Company, 414 Nicollet Mall, Minneapolis, MN 55401

118. Roger W. Taylor, Senior Utilities Engineer, National Renewable Energy Laboratory, 1617 Cole Boulevard, Golden, CO 80401-3393

119. F. M. Tesche, Consulting Scientist, 6714 Norway Road, Dallas, TX 75230

120. Susan F. Tierney, The Economic Resource Group, Inc., One Mifflin Place, Cambridge, MA 02138

121. D. R. Volzka, Senior Project Engineer, Wisconsin Electric Power Company, 333 West Everett Street, Milwaukee, WI 53201

122. Rebecca Vories, Infinite Energy, P.O. Box 481905, Denver, CO 80248

123. C. Michael Walton, Ernest H. Cockrell Centennial Chair in Engineering and Chairman, Department of Civil Engineering, University of Texas at Austin, Austin, TX 78712-1414

124. Yih-huei Wan, P.E., Senior Utility Systems Analyst, National Renewable Energy Laboratory, 1617 Cole Boulevard, Golden, CO 80401-3393

125. Lee E. Westbrook, Manager, Transmission Planning, TUElectric, 400 N. Olive Street, L.B. 81 , Dallas, TX 75201

126-135. H. W. Zaininger, ZECO, 1590 Oakland Road, Suite B211, San Jose, CA 95131

136. Office of Assistant Manager for Energy, Research and Development, DOE-ORO, P.O. Box 2001, Oak Ridge, TN 37831

137-138. OSTI, U.S. Department of Energy, P.O. Box 62, Oak Ridge, TN 37831 